\title{
NEOTECTONICS AND PALEOSEISMICITY OF A MAJOR JUNCTION BETWEEN TWO STRANDS OF THE Awatere Fault, South Island, New Zealand
}

\author{
Dougal P. M. Mason
}

\author{
A thesis \\ submitted to the Victoria University of Wellington \\ in partial fulfilment of the requirements for \\ the degree of \\ Master of Science \\ in Geology
}

Victoria University of Wellington

2004 


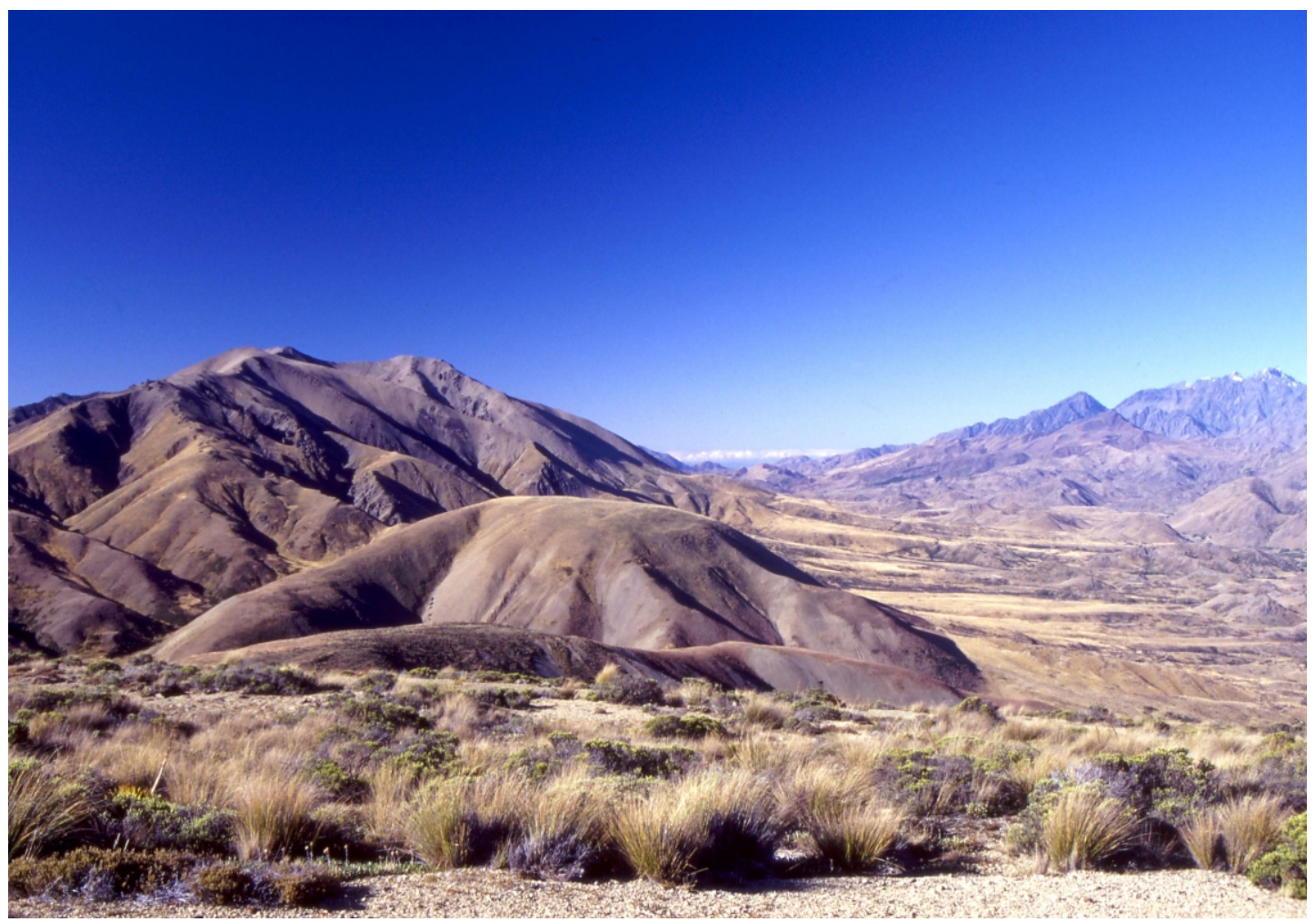

Frontispiece: The upper Awatere Valley, looking northeast from Mt Chisholm toward Shingle Peak. 


\section{ABSTRACT}

In northeastern South Island, New Zealand, obliquely-convergent relative motion between the Pacific and Australian plates is accommodated by slip across active dextral-oblique faults in the Marlborough fault system. The Awatere Fault is one of four principal active strike-slip faults within this plate boundary zone, and includes two sections (the eastern and Molesworth sections) that have different strikes and that join across a complex fault junction in the upper Awatere Valley.

Detailed mapping of the fault traces and measurement of 97 geomorphic displacements along the Awatere Fault in the vicinity of the fault junction show that the eastern and Molesworth sections of the fault intersect one another at a low angle $\left(10-15^{\circ}\right)$, at the eastern end of an internally faulted, elongate, $\sim 15 \mathrm{~km}$ long and up to $3 \mathrm{~km}$ wide fault wedge or sliver. The region between the fault sections is split by a series of discontinuous, en-echelon scarps that are oriented from $\sim 10^{\circ}$ to $20-30^{\circ}$ clockwise from the principal fault sections. Based on other observations of discontinuities in strike-slip earthquake ruptures around the globe, this low-angle intersection geometry suggests that the junction between these fault sections may not act as a significant barrier to earthquake rupture propagation. This interpretation of the mechanical significance of the fault junction to earthquake ruptures is counter to previous suggestions, but is supported by new paleoseismic data from four paleoseismic trenches excavated on each side of the junction. In a new paleoseismic trench on the Molesworth section at Saxton River, $18 \mathrm{~km}$ to the west of the junction, up to ten surface-rupturing events in the past $\sim 15 \mathrm{ka}$ are recognised from 12 radiocarbon ages and 1 optically stimulated luminescence age. In two new trenches on the eastern section near to Upcot Saddle, $12 \mathrm{~km}$ northeast of the fault junction, five events took place in the past $5.5 \mathrm{ka}$, based on 21 radiocarbon ages. This chronology from Upcot Saddle is combined with data from two previous trenches located $\sim 55 \mathrm{~km}$ to the northeast at Lake Jasper, to infer nine events on the eastern section since $8330-8610$ cal. years B.P. These well-dated events on the eastern section are compared to those on the Molesworth section to the west of the fault junction. At 95\% confidence, five events on both sections have occurred with statistical contemporaneity since $\sim 6$ ka B.P. These five events may have ruptured both the eastern and Molesworth sections simultaneously, in accordance with the 
interpretation that the fault section junction does not arrest rupture propagation. Alternatively, these events may have been separate earthquakes that occurred within the statistical resolution provided by radiocarbon dating.

The most recent event to rupture the eastern section was the $\mathrm{Mw} \sim 7.51848$ Marlborough earthquake. The coseismic slip distribution and maximum traceable length of this surface rupture are calculated from the magnitude and distribution of small, metre-scale geomorphic displacements attributable to this earthquake. These data suggest this event ruptured $>100-110 \mathrm{~km}$ of the eastern section, with mean surface displacement of $5.3 \pm 1.6 \mathrm{~m}$. Based on these parameters, the moment magnitude of this earthquake would be $\mathrm{M}_{\mathrm{w}}$ 7.4-7.7. This magnitude estimate is indistinguishable from previous calculations that were based on attenuation of shaking intensity isoseismals that were assigned from contemporary historical accounts of that earthquake. On the basis of similar rupture lengths and coseismic displacements, it is inferred that the penultimate event had a similar moment magnitude to the 1848 earthquake.

Horizontal displacement of a flight of 6 fluvial terraces at Saxton River by the Molesworth section of the Awatere Fault is constrained to have occurred at a nearconstant rate of $5.5 \pm 1.5 \mathrm{~mm} / \mathrm{a}$ since $\sim 15 \mathrm{ka}$ B.P. These rates are based on two new optically stimulated luminescence ages for the highest terrace treads of $14.5 \pm 1.5$ and $6.69 \pm 0.74$ ka B.P. These rates are indistinguishable from recent strike-slip rate estimates for the eastern section of $5.6 \pm 1.1$ and $6 \pm 2 \mathrm{~mm} / \mathrm{a}$. Comparing the magnitudes and ages of the terrace riser displacements at Saxton River to the timing of paleoearthquakes on the Molesworth section implies a mean per-event displacement of $4.4 \pm 0.2 \mathrm{~m}$ since $\sim 15 \mathrm{ka}$. The new terrace ages also record two periods of aggradation that post-date the Last Glacial Maximum. 


\section{ACKNOWLEDGEMENTS}

My greatest thanks go to my supervisor, Tim Little, for all his knowledge, advice and critical assessment. This project would have suffered greatly had it not been for Tim's expertise and vision. Similarly, gathering and interpretation of paleoseismic data for this project benefited immensely from the expert guidance, and infectious enthusiasm, of Russ Van Dissen.

This research was funded by a grant from the New Zealand Earthquake Commission, as well as Graduate and Postgraduate scholarships awarded by Victoria University of Wellington. Thanks to David Dowrick, Euan Smith, Rob Langridge, Uwe Rieser, Alan Hogg, Nick Boyens and Nigel Hill for their vital technical assistance, input and discussion of ideas.

That four paleoseismic trenches were excavated and logged without hindrance, in a remote part of Marlborough, is testament to the efforts of the legion of enthusiastic field assistants: Tracey Bear, Matt Hill, Nigel Hill, Dougal Townsend, Ruth Wightman, and Kate Wilson. Special thanks go to Matt, for braving the vagaries of El Nino "summer" weather in the Awatere Valley over three field seasons, for his Herculean efforts excavating, logging and de-watering the four trenches, for his tolerance and sense of humour in the office, and for his expert golf tuition. Ruth earns my heartfelt gratitude for volunteering to proof-read the lengthy draft chapters. Thanks also to Kate, Dan and Nora for providing a relaxed and enjoyable office atmosphere.

Thankyou to the landowners in the upper Awatere Valley who kindly granted me free access to their property, aided in the excavation and infilling of the four trenches, and provided palatial field accommodation: Jim and Tracey Ward (Molesworth station), Steve and Mary Satterthwaite (Muller station), and Bill and Pam Stephenson (Upcot station).

The keen interest and support shown by my parents, Barbara and Andrew, and my sisters, Catriona and Kirsten, was unwavering throughout the duration of this project. This thesis would also not have been possible without Natalie's unconditional and unrelenting patience, understanding and support, all of which helped maintain my motivation when it otherwise might have faltered. 


\section{CONTENTS}

FRONTISPIECE II

AbSTRACT

ACKNOWLEDGEMENTS V V

$\begin{array}{ll}\text { CONTENTS } & \text { VI }\end{array}$

$\begin{array}{lll}\text { LIST OF FIGURES } & \text { XII }\end{array}$

1. INTRODUCTION 1 


\section{Neotectonic GeOlogy OF THE AWATERe FAUlt IN THE VICINITY OF A FAULT SECTION JUNCTION, INLAND Marlborough, NeW ZeAland}

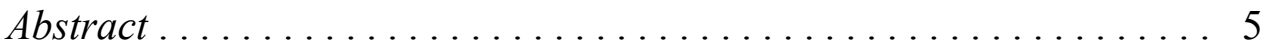

2.1. Introduction $\ldots \ldots \ldots \ldots \ldots \ldots \ldots \ldots \ldots \ldots \ldots \ldots$

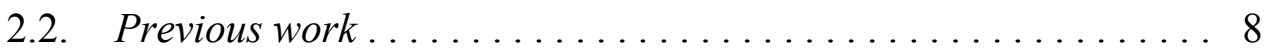

2.3. Study methods........................ 10

2.4. Neotectonics of the Awatere Fault in the upper Awatere and Acheron Valleys ........................... 10

2.4.1. Quaternary landforms and surficial deposits......... 10

2.4.2. Tectonic geomorphology of faulting. . . . . . . . . 14

The eastern section between Grey River and Castle River. . . . . . 15

The eastern section between Castle River and Wards Pass . . . . . 17

The eastern section between Wards Pass and Guide River . . . . 18

The Molesworth section between Isolated Flat and Kennet River 21

The Mt Chisholm block. . . . . . . . . . . . . . 22

Late Quaternary slip rates on the eastern section. . . . . . . . . . 24

2.5. Discussion ............................. 25

2.5.1. Relationships between fault strike and the amount and sense of vertical displacement. . . . . . . . . . . 25

2.5.2. Location of the junction between the eastern and

Molesworth sections . . . . . . . . . . . . . . . . . 29

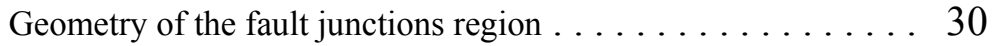

Implications for possible segmentation of earthquake ruptures on the Awatere Fault in the upper Awatere Valley. . . . . . . . . 30

2.5.3. Southwestern extent of the eastern section ......... . 34

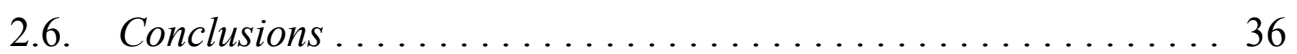




\section{INFLUENCE OF A FAULT SECTION JUNCTION ON THE RUPTURING BeHAViOUR OF THE AWATERE FAULT, NeW ZEALAND}

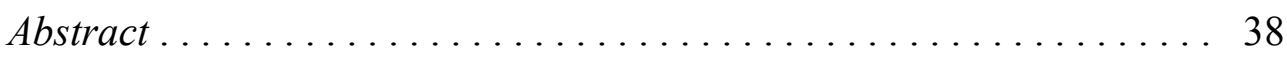

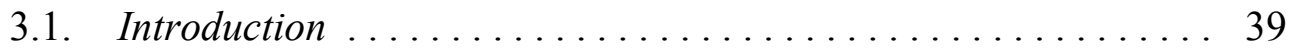

3.2. Previous work ....................... 41

3.3. Paleoseismology of the Molesworth section at Saxton River . . . . 42

3.3.1. Saxton River trenches . . . . . . . . . . . . . . 42

Stratigraphy and structure of fault strands and sediments exposed in the Saxton-2 trench . . . . . . . . . . . . . . . 44

Paleoseismic record preserved in the Saxton-2 trench . . . . . . 51

3.3.2. Integrated paleoseismic history for the Molesworth section ..................... 58

3.4. Paleoseismology of the eastern section in the upper Awatere Valley................................ 60

3.4.1. Upcot-1 trench . . . . . . . . . . . . . . . . 60

Stratigraphy and structure of fault strands and sediments exposed in the Upcot-1 trench. . . . . . . . . . . . . . . 60

Paleoseismic record preserved in the Upcot-1 trench . . . . . . . 65

3.4.2. Upcot-2 trench . . . . . . . . . . . . . . . . 68

Stratigraphy and structure of fault strands and sediments exposed in the Upcot- 2 trench. . . . . . . . . . . . . . . . 68

Paleoseismic record preserved in the Upcot-2 trench . . . . . . 70

3.4.3. Synthesis of results from the Upcot trenches . . . . . . . 72

3.4.4. Integrated paleoseismic history for the eastern section . . 72

3.5. Discussion ......................... 77

3.5.1. Earthquake recurrence intervals . . . . . . . . . . 77

Molesworth section. . . . . . . . . . . . . . . . . 77

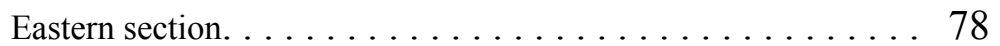

3.5.2. Rupture segmentation of the Awatere Fault ... . . . . . . 79

3.5.3. Implications for seismic hazard assessment . . . . . 82

3.6. Conclusions . . . . . . . . . . . . . . . . . . . . . . . . 83 


\section{REFINED SLIP DISTRIBUTION AND MOMENT MAGNITUDE FOR THE}

1848 Marlborough EarthQUaKe, New Zealand

Abstract .................................. 86

4.1. Introduction .......................... 87

4.2. Previous work on the 1848 earthquake .............. 89

4.2.1. Seismicity . . . . . . . . . . . . . . . . . . . . 89

4.2.2. Slip distribution $\ldots \ldots \ldots \ldots \ldots \ldots \ldots \ldots \ldots, \ldots \ldots \ldots$

4.3. Estimates of surface rupture length ................ 91

4.3.1. Uncertainties in rupture length calculation . ........ 92

4.4. Surface displacements . . . . . . . . . . . . . . . . . . . . . . 94

4.4.1. Magnitude and distribution of single-event offsets ..... 94

Variation in slip magnitude and sense of throw. . . . . . . . 98

4.4.2. Uncertainties in displacement measurement ......... 100

4.4.3. Second-smallest offsets . . . . . . . . . . . . . . . 101

4.5. Discussion: Displacement-length scaling relationships ........ 102

4.5.1. Length-averaged mean displacement .............. 102

4.5.2. Slip distribution $\ldots \ldots \ldots \ldots \ldots \ldots \ldots \ldots \ldots \ldots \ldots$

4.5.3. Implications for incorporation of Molesworth section displacement .......................... 105

4.5.4. Revision of moment magnitude for the 1848 earthquake . 108

4.5.5. Characteristics of the penultimate event ........... 110

4.6. Conclusions ................................... 111 


\section{RATES OF ACTIVE FAULTING DURING LATE QUATERNARY}

FLUVIAL TERRACE FORMATION AT SAXTON RIVER, AWATERE

FAULT, NeW ZEALAND

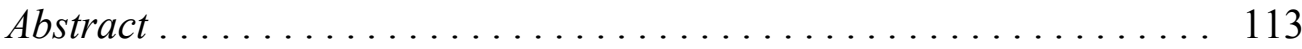

5.1. Introduction . . . . . . . . . . . . . . . . . . . . . . . . 114

5.2. Regional context ....................... 116

5.2.1. The displaced terrace sequence at Saxton River ...... 116

5.2.2. Mechanisms for late Quaternary fluvial terrace formation in central New Zealand . . . . . . . . . . . . . . . . 119

5.3. Terrace measurements ....................... 121

5.3.1. Fault displacements $\ldots \ldots \ldots \ldots \ldots \ldots \ldots \ldots \ldots$

5.3.2. Tread widths . . . . . . . . . . . . . . . . . . . . . . . . . . 129

5.4. Terrace abandonment ages . . . . . . . . . . . . . . . 133

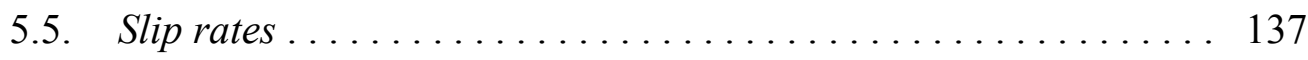

5.6. Discussion . . . . . . . . . . . . . . . . . . . . . . . . . 139

5.6.1. Slip rates of the Molesworth section of the Awatere Fault 139

5.6.2. Relationship between paleoseismicity and terrace displacements at Saxton River . . . . . . . . . . . . . . . . 141

Paleoseismicity . . . . . . . . . . . . . . . . 141

Holocene throw reversal. . . . . . . . . . . . . . . . . . . . 144

5.6.3. Implications of new slip rate estimates for the Awatere Fault and Marlborough fault system . . . . . . . . 146

5.6.4. Climatic implications of new terrace ages . . . . . . . 147

5.7. Conclusions ........................... 151 
$\begin{array}{ll}\text { REFERENCES } & 156\end{array}$

\section{APPENDIX A. GEOMORPHIC LANDFORMS DISPLACED BY THE}

AWatere Fault in the UPPER AWatere AND ACHERon

\section{RIVER VALLEYS}

Table A.1. Fault displacements measured along the eastern and

Molesworth sections of the Awatere Fault ........... 163

\section{APPENDIX B. LITHOLOGICAL DESCRIPTIONS OF STRATIGRAPHIC UNITS IDENTIFIED IN THE SAXTON AND UPCOT TRENCHES}

Table B.1. Units identified in the Saxton-2 trench . . . . . . . . . . 167

Table B.2. Units identified in the Upcot-1 trench. . . . . . . . . . . . . . 169

Table B.3. Units identified in the Upcot-2 trench. . . . . . . . . . . . 172 


\section{NeOtectonic GEOLOGY OF THE AWATERE FAULt IN THE} VICINITY OF A FAULT SECTION JUNCTION, INLAND MARLBOROUGH, NeW ZEALAND

2.1.a-c Tectonic setting of northeast South Island $\ldots \ldots \ldots \ldots \ldots$

2.2. Neotectonic map of the Awatere Fault .............. 11

2.3. Oblique photograph of landforms in the upper Awatere Valley. . 13

2.4. Histogram of 100 late Quaternary horizontal displacements. . . . 16

2.5. Map of the southwestern extent of the eastern section. . . . . . . 20

2.6. Map of the fault junctions region and Mt Chisholm block . . . . 23

2.7. Map of the deflected channel and spur near Upcot Saddle . . . . 26

2.8.a-b Graph of vertical to horizontal slip ratios for faulted landforms. . 28

2.9.a-b Aerial photograph of the eastern-Molesworth section junction. . 31

2.10. Digital terrain model of the fault junctions region. . . . . . . . 32

\section{INFLUENCE OF A FAULT SECTION JUNCTION ON THE RUPTURING}

\section{behaviour of The AWatere Fault, NeW ZeAland}

3.1.a-c Tectonic setting of northeast South Island . . . . . . . . . . . 40

3.2. Neotectonic map of the Saxton River trench site . . . . . . . 43

3.3. $\quad \log$ of the east wall of the Saxton-1 trench. . . . . . . . 45

3.4. $\quad$ Log of the east wall of the Saxton- 2 trench. . . . . . . . 46

3.5. Enlargement of the east wall, Saxton-2 trench . . . . . . . 47

3.6. $\quad \log$ of the west wall of the Saxton-2 trench . . . . . . . . 48

3.7. Age calibrations of ${ }^{14} \mathrm{C}$ samples from the Saxton-2 trench. . . . 53

3.8.a-b Earthquake chronologies of the Molesworth section, Awatere F 59

3.9.a-b Neotectonic map of the Upcot Saddle trench site. . . . . . . . 61

3.10. $\log$ of the northeast wall of the Upcot-1 trench . . . . . . . . 62

3.11. Log of the southwest wall of the Upcot-1 trench . . . . . . 63

3.12. Log of the southwest wall of the Upcot-2 trench . . . . . . . 69

3.13.a-c Earthquake chronologies of the eastern section at Upcot Saddle 73 
3.14.a-c Earthquake chronology of the entire eastern section, Awatere F 74

3.15.a-b Combined surface rupture chronology for the Awatere Fault. . 81

\section{REFINED SLIP DISTRIBUTION AND MOMENT MAGNITUDE FOR THE}

\section{Marlborough EaRTHQUaKe, NeW ZeALAND}

4.1.a-c Tectonic setting of northeast South Island. . . . . . . . . . . 88

4.2. Map of small geomorphic displacement sites . . . . . . . 93

4.3. Microtopographical map of two coseismic displacements. . . . . 97

4.4.a-b Graph of vertical to horizontal slip ratios for coseismic offsets. . 99

4.5. Graph of coseismic slip distribution for the 1848 earthquake . . . 104

4.6. Map of prominent scarps through Mt Chisholm . . . . . . . . 106

\section{RATES OF ACTIVE FAULTING DURING LATE QUATERNARY FLUVIAL} TERrACE Formation At SAXton River, AWATERe FAult, NeW

\section{ZEALAND}

5.1.a-c Tectonic setting of northeast South Island. . . . . . . . . . 115

5.2.a-b Photograph and block diagram of the Saxton River terraces. . . . 117

5.3.a-b Terrace geometry interpreted from aerial photograph mapping . . 118

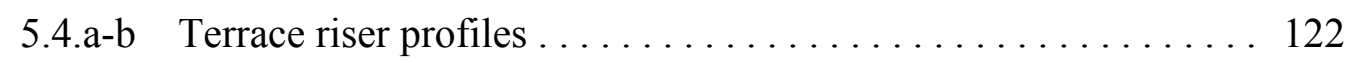

5.5.a-b Terrace geometry interpreted from GPS-based mapping. . . . . . 124

5.6.a-g Individual maps of terrace riser displacements . . . . . . . . 125

5.7. Schematic diagram of faulting during terrace formation. . . . . 130

5.8. Stratigraphy of new OSL samples . . . . . . . . . . . . 134

5.9.a-b Graph of incremental strike slip rates. . . . . . . . . . . . . . 140

5.10. Graph of cumulative horizontal and vertical terrace offsets . . . 143

5.11. Graph of incremental fluvial incision rates . . . . . . . . . 150

\section{APPENDIX A. GEOMORPHIC LANDFORMS DISPLACED BY THE}

\section{Awatere Fault in the UPPER Awatere ANd ACHERon}

\section{RIVER VALLEYS}

A.1. Neotectonic map of the Awatere Fault ........ Back pocket 


\section{INTRODUCTION}

Geometrical discontinuities within active fault systems, such as fault bends, stepovers or intersections, may divide faults into mechanical segments that rupture separately during earthquakes, with the discontinuities between these segments acting as barriers to rupture propagation and/or preferred sites of rupture nucleation (e.g., Aki, 1984; Schwartz and Coppersmith, 1984; King and Nabelek, 1985; Sibson, 1986). Understanding the role of such geometrical complexities in the earthquake rupturing process is important for seismic hazard assessment, because potential earthquake magnitudes on faults are commonly assessed on the basis of the maximum length of a future rupture, a dimension that may be limited by any mechanical segmentation of the fault. While dynamic propagation of the 1992 Landers earthquake in California and the 1999 Izmit earthquake in Turkey were temporarily impeded by a series of releasing stepovers $1-5 \mathrm{~km}$ wide, these ruptures ultimately propagated across the stepovers (Zachariasen and Sieh, 1995; Lettis et al., 2002). Similarly, paleoseismic investigations of the San Andreas Fault suggest that large earthquake ruptures can propagate across apparent segment boundaries along that fault (e.g., Grant and Sieh, 1994). Other segment boundaries, however, do impede rupture propagation, for example the 1999 Izmit earthquake rupture terminated eastward across a $\sim 4 \mathrm{~km}$-wide releasing stepover at Eften Lake (Lettis et al., 2002). Similarly, paleoseismic, geomorphic, topographic and geophysical data suggest that distinct structural discontinuities along the Wasatch fault zone in Utah confine major slip events to discrete parts of the fault zone, that represent only a fraction of the fault's total length (Schwartz and Coppersmith, 1984; Machette et al., 1991).

In northeast South Island, New Zealand, obliquely convergent relative motion between the Pacific and Australian plates is accommodated through the Marlborough fault system, a zone of dextral-slip faults. The Awatere Fault, one of four principal strike-slip faults within this plate boundary zone, is comprised of two geometric sections (the eastern and Molesworth sections) that have different strikes and that intersect across a complex fault junctions region in the upper Awatere Valley. Previous historical data suggest that this junction may have acted as a significant 
mechanical barrier to earthquake rupture propagation, as rupture of $>100 \mathrm{~km}$ of the eastern section of the Awatere Fault during the $\mathrm{M}_{\mathrm{w}} \sim 7.51848$ Marlborough earthquake apparently did not trigger rupture of the adjacent Molesworth section (Grapes et al., 1998). While the neotectonics and paleoseismicity of the Molesworth section (McCalpin, 1996a) and the northeastern end of the eastern section (Little et al., 1998; Benson and Little, 2001; Benson et al., 2001; Hill et al., 2001) have each been studied recently, no attempt has been made to evaluate the location, magnitude and distribution of late Quaternary scarps and geomorphic displacements across the fault junction region, or the processes of slip transfer through the junction during earthquakes. Nor have any detailed paleoseismic studies been undertaken there. This thesis focuses on the prominent junction between the two geometric sections of the Awatere Fault, and assesses how it may have influenced the location, magnitude and rates of late Quaternary deformation, and earthquake rupture dynamics.

The thesis is comprised of four self-contained chapters that describe a different aspect of the structure, paleoseismicity and rates of active deformation of the Awatere Fault in the vicinity of the junction between the eastern and Molesworth fault sections. Each chapter is intended to be individually submitted for possible publication, and consequently a certain amount of introductory material is repeated at the beginning of each chapter. In Chapter 2, the results of detailed field mapping of the active traces of the Awatere Fault are presented. These data clarify the styles of surface faulting along the oblique-slip Awatere Fault, and refine the location, dimensions and kinematics of the junction between the eastern and Molesworth sections. Comparing the geometry and tectonic geomorphology of the fault junctions region to geometrical discontinuities that were pervasively ruptured during modern strike-slip earthquakes in California and Turkey allows evaluation of the possible kinematic influence of this junction on the rupturing behaviour of the Awatere Fault. Detailed mapping of the remote southwestern end of the eastern section reveals the location and surface expression of the Awatere Fault in this area, and addresses the possibility that this fault may join with the oblique-slip Clarence Fault here. Also presented in this chapter are refined estimates of late Quaternary strike-slip rates for the eastern section.

Chapter 3 presents new data, including 33 radiocarbon dates and 1 optically stimulated luminescence date, from four paleoseismic trenches that were excavated 
on both sides of the fault junction between the eastern and Molesworth sections of the Awatere Fault. Refined late Quaternary surface rupture chronologies are constructed for both sides of the fault junctions region, and allow evaluation of whether large paleoearthquakes may have broken across the fault junction to rupture both sections simultaneously. The new, integrated rupture chronologies for the eastern and Molesworth sections show statistical contemporaneity (at 95\% confidence) in the occurrence of five paleoearthquakes younger than $\sim 6 \mathrm{ka}$ B.P., including the 1848 Marlborough earthquake. These relationships strongly suggest that large magnitude earthquakes have broken across the fault junction in the late Quaternary, with the consequent inference that the junction may not act as a significant barrier to earthquake rupture propagation. Alternatively, these apparent overlaps may represent separate earthquakes that ruptured each fault section individually, and occurred within a time period beyond the resolution of contemporary radiocarbon dating.

Chapter 4 focuses on the $\mathrm{M}_{\mathrm{w}} \sim 7.51848$ Marlborough earthquake. In this chapter the distribution and magnitude of metre-scale displacements of geomorphic landforms are used to infer the rupture length, slip distribution and the mean surface displacement of that historical earthquake. These data allow the moment magnitude of the 1848 earthquake to be re-evaluated, which is estimated to be $M_{w}$ 7.4-7.7. This is similar to previous magnitude estimates based on attenuation relationships of shaking intensity isoseismals assigned on the basis of historical data. The magnitudes of the second-smallest, metre-scale geomorphic displacements are used as a proxy for the amount of coseismic slip that has accrued since the penultimate event on the eastern section, at $\sim 1$ ka B.P. These data suggest that the penultimate event was of comparable magnitude to the 1848 event.

In Chapter 5, the rates of late Quaternary strike slip on the Molesworth section of the Awatere Fault are re-evaluated for a flight of six especially wellpreserved, and dated, fault-displaced terraces at Saxton River. This chapter presents two new optically stimulated luminescence ages that date abandonment of the highest two (aggradation) terraces. New estimates of horizontal and vertical displacements, based on a comprehensive re-survey of the terraces with a real time kinetic global positioning system (RTK-GPS), are combined with the new age data to estimate the rates of strike slip and the magnitude of per-event displacements on this 
part of the Molesworth section. The new terrace abandonment ages also record two post-glacial phases of fluvial aggradation by Saxton River.

Displacements of geomorphic landforms measured during detailed mapping of the active traces of the eastern and Molesworth sections of the Awatere Fault are summarised in Appendix A. The offset data are summarised in Table A.1, and the locations of sites where offset measurements were made are shown in Figure A.1 (enclosed in back pocket). Appendix B contains detailed lithological descriptions and calibrated radiocarbon ages of the stratigraphic units which were identified during logging of the four paleoseismic trenches described in Chapter 3. 


\section{NeOteCtONiC GeOlogy OF THE AWATERE FAUlT IN THE VICINITY OF A FAULT SECTION JUNCTION, INLAND MARLBOROUGH, NEW ZEALAND}

\section{ABSTRACT}

The Awatere Fault is one of four principal strike-slip faults within the obliquely-convergent plate boundary zone in northeastern South Island, New Zealand. It includes two sections (the eastern and Molesworth sections) that have different strikes and that intersect one another across a complex fault junction region in the upper Awatere Valley. This chapter presents the results of detailed mapping and analysis of the active traces of the Awatere Fault in the areas surrounding this junction, including measurement of horizontal fault displacements of 100 geomorphic features, with results ranging between $2.2 \mathrm{~m}$ and $180 \mathrm{~m}$. These data refine the styles of oblique-slip faulting along this active fault, and the location, geometry and segmentation of the fault-section junction. Variations in the sense of throw and the ratios of vertical to horizontal slip observed for geomorphic displacements along the eastern and Molesworth sections can only be partially modelled by a rigid block model of faulting associated with variable local strikes of the fault. Much of the near-surface vertical-slip is interpreted to be the result of complex deformation associated with nearby off-fault structures, including secondary horsts and grabens. Contrary to earlier mapping, the eastern and Molesworth sections are shown to intersect one another at a low angle $\left(10-15^{\circ}\right)$, with an elongate, wedge-shaped $(<3 \mathrm{~km}$ wide by $15 \mathrm{~km}$ long) fault junctions region between the two faults. On the basis of global observations of earthquake rupture in other discordant strike-slip zones, this geometry suggests that the fault junction may not act as a significant barrier to rupture propagation, and therefore that the two principal fault sections may rupture simultaneously across the fault junctions region. In the faulted block between the two fault strands, there are abundant sinuous, discontinuous scarps striking $<10^{\circ}$ and $20-30^{\circ}$ clockwise from the main faults. These faults split the flat-topped bedrock hills within the fault junctions region, and are spaced, on average, $\sim 175 \mathrm{~m}$ apart. The geometry and spacing of these faults suggest they may have accommodated the transfer of coseismic, dextral-oblique slip between the principal fault sections during the propagation of large earthquake ruptures, similar to patterns observed elsewhere within stepover regions along large strike-slip earthquake ruptures. To the southwest of Barefell Pass, the eastern section of the Awatere Fault is defined by a topographic lineation of notched bedrock ridges along the flanks of the Rachel Range, but the scarp is poorly preserved here because these hillslopes are mantled by active scree slopes. This alignment of notches extends to within $500 \mathrm{~m}$ of the Clarence Fault, suggesting the Awatere and Clarence Faults may meet across an acute intersection $\left(10-30^{\circ}\right)$ near the confluence of the Guide and Acheron Rivers. 


\subsection{INTRODUCTION}

Geometrical discontinuities within active fault zones, such as fault bends, stepovers or intersections, may divide faults into mechanical segments that rupture discretely in characteristic earthquakes (e.g., Aki, 1984; Schwartz and Coppersmith, 1984). Such discontinuities may act as barriers to rupture propagation and/or preferred sites of rupture nucleation (e.g., King and Nabelek, 1985; Sibson, 1986). While models of earthquakes based on the segmentation of a fault zone can be applied successfully, paleoseismic evidence (e.g., Grant and Sieh, 1994) and modern observations (e.g., Zachariasen and Sieh, 1995; Lettis et al., 2002) suggest large earthquake ruptures can propagate across apparent segment boundaries defined by structural discontinuities (Rubin, 1996). The geometry of these discontinuities, rather than simply their presence or absence, appears to be the important factor that may influence earthquake rupture propagation (e.g., Barka and Kadinsky-Cade, 1988).

In northeast South Island, New Zealand, obliquely convergent relative motion between the Pacific and Australian plates is accommodated through the Marlborough fault system, a zone of dextral-slip faults. The Awatere Fault includes two sections (the eastern and Molesworth sections; see Figure 2.1), which differ by $15-20^{\circ}$ in their strike and which intersect conspicuously near the Molesworth Station homestead in the upper Awatere Valley. Previous paleoseismic research suggests that this junction may have acted as a significant mechanical barrier to earthquake rupture propagation (Grapes et al., 1998). The eastern section of the Awatere Fault last ruptured during the $\mathrm{M}_{\mathrm{w}} \sim 7.51848$ Marlborough earthquake, when surface rupture on the eastern section was traced by first-hand accounts from the coast to at least as far as Barefell Pass (Grapes et al., 1998). Importantly, available historical reports suggest the rupture bypassed the fault junction without triggering rupture of the Molesworth section of the fault. The occurrence of well-preserved, fresh-looking scarps along the Molesworth section just to the west of the fault junctions region, however, is consistent with a recent or historic rupture there. While the neotectonics and paleoseismicity of the Molesworth section (McCalpin, 1996a) and the northeastern end of the eastern section (Little et al., 1998; Benson and Little, 2001; Benson et al., 2001; Hill et al., 2001) have each been studied recently, no attempt has 


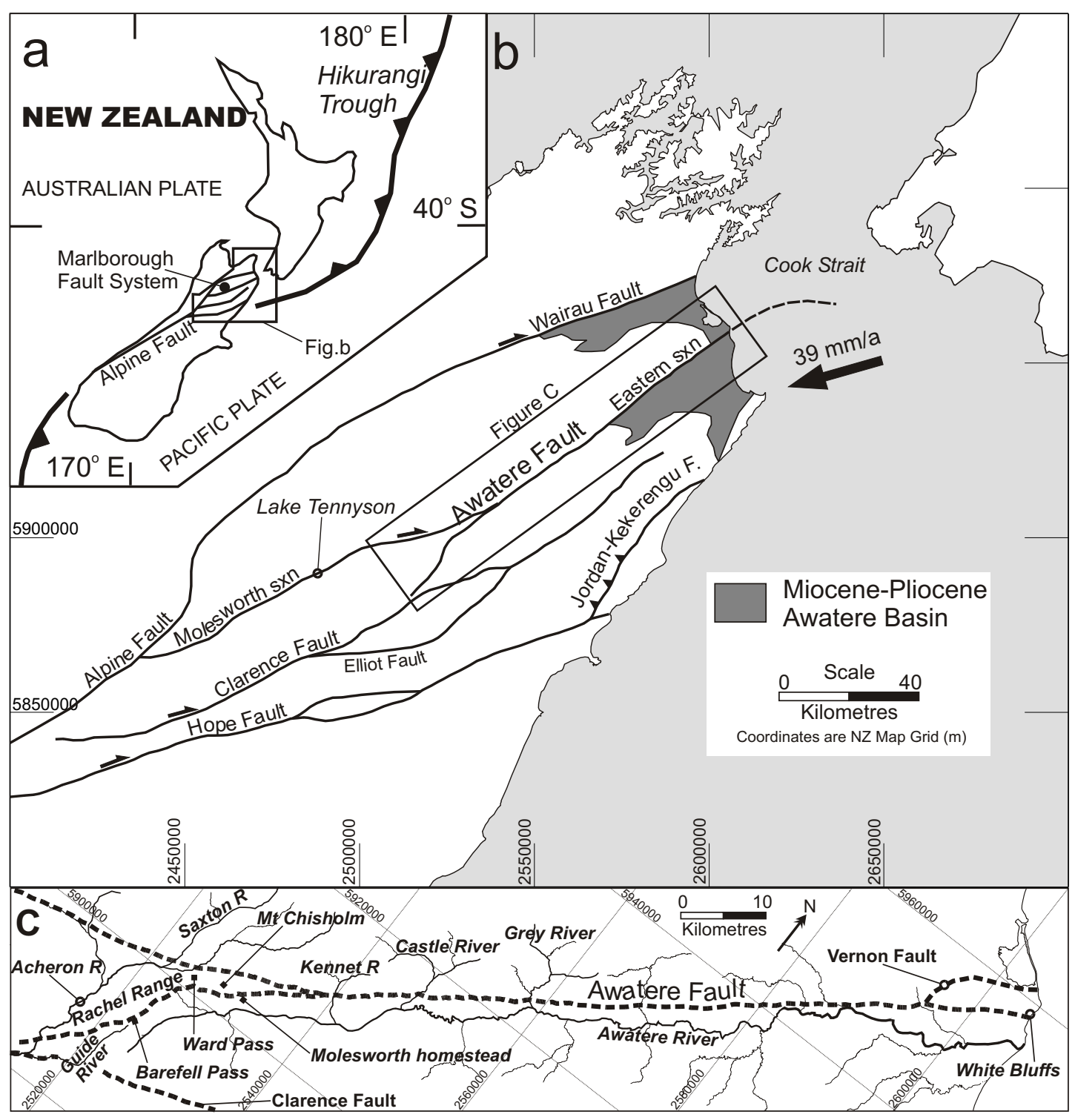

Figure 2.1a-c. (A) Map showing Pacific-Australia plate boundary through New Zealand. (B) Map of the Marlborough fault zone (northeast South Island), with principal active faults shown (after Little and Roberts, 1997; Little et al., 1998; Nicol and Van Dissen, 2002). The bold arrow indicates the azimuth and magnitude of Pacific plate motion relative to the Australian plate (de Mets et al., 1990; 1994); the offshore extent of the Awatere fault is adapted from Carter et al. (1988). (C) Location map of the active Awatere Fault trace from the east coast at White Bluffs to Acheron River. 
been made to evaluate the location, magnitude and distribution of late Quaternary scarps and geomorphic displacements in the area. These data would have implications for understanding the processes of slip transfer through the fault junctions region during earthquakes.

The southwestern extent of the eastern section of the Awatere Fault is poorly defined (Figure 2.1). Lensen (1963) mapped the eastern section at the 1:250,000 scale, showing the fault intersecting the Clarence Fault in the Guide River Valley, to the south-southwest of Barefell Pass. At the 1:50,000 scale, Kieckhefer (1979) mapped scarps and fault displacements of the Clarence Fault in the Guide and Acheron River valleys, but identified no late Quaternary scarps in this area that might be attributable to the nearby Awatere Fault. The possibility of a junction between the Awatere and Clarence Faults has therefore been unresolved.

This chapter presents the results of detailed field mapping of the active traces of the Awatere Fault in the upper Awatere and Acheron River valleys. The study area is comprised of three principal strands that make up the Awatere Fault zone in this region: the eastern section trace, from Grey River southwest to Guide River; the Molesworth section trace, from Saxton River east to Kennet River; and the elongate, internally faulted block between the two fault sections (termed the "Mt Chisholm block" by McCalpin, 1996a). Detailed mapping in these areas clarify the styles of surface faulting across a major fault junctions region along an active strike-slip fault. The objectives of this study are (1) to document the neotectonics and tectonic geomorphology of the eastern and Molesworth sections of the Awatere Fault in the vicinity of the fault junctions region, including the well-preserved scarps throughout this fault-bounded block, and (2) to delineate the extent of the remote and poorly studied strand of the Awatere Fault to the southwest of Barefell Pass; in particular to assess whether it links with the Clarence Fault to the southwest.

\subsection{PREVIOUS WORK}

The Awatere Fault extends inland from the east coast of the South Island at White Bluffs to the Alpine Fault near Lewis Pass, a distance of $>200 \mathrm{~km}$. The eastern $\sim 100 \mathrm{~km}$ of the fault trace has a mean strike of $\sim 057^{\circ}$ and generally dips $65^{\circ}$ $88^{\circ}$ to the northwest, although it locally undergoes changes in strike and dip at length 
scales of $10-10^{4} \mathrm{~m}$ (Little et al., 1998; Benson and Little, 2001). Mountainous topography on the northwest side of the Awatere Fault suggests that the long-term sense of vertical displacement on that structure is reverse. The Awatere Fault was mapped by Suggate et al. (1961) and Lensen (1963) at 1:250,000 scale. Offset of metamorphic isograds in the Torlesse Terrane near the western end of the fault led Suggate et al. (1961) to infer no more than $\sim 6.4 \mathrm{~km}$ (4 miles) of dextral slip on the Awatere Fault, a figure increased to $\sim 13 \mathrm{~km}$ by McLean (1986). Little and Jones (1998) measured a minimum finite dextral offset of $34 \pm 10 \mathrm{~km}$ across the eastern section, including several inactive strands, since $\sim 7$ Ma using a facies boundary within Late Miocene strata of the Awatere basin. These authors also conclude that slip on the eastern section of the Awatere Fault commenced some time since $7 \mathrm{Ma}$ whereas the even younger, presently active strand near the coast was established $<1$ Ma. Marine seismic profiles conducted by Carter et al. (1988) show that the eastern section of the Awatere Fault probably terminates $\sim 20 \mathrm{~km}$ offshore, within Cook Strait.

McCalpin (1992a, 1992b, 1996a) presented stratigraphic, geomorphic and paleoseismological data on the more inland Molesworth section of the Awatere Fault, including a mean strike slip rate estimate of $\sim 8 \mathrm{~mm} / \mathrm{a}$ since the Last Glacial Maximum for that part of the fault. Lensen (1964b, 1973) noted terrace displacements at Grey River and Saxton River; Knuepfer $(1988,1992)$ used pebble weathering rind and soil morphology ages to calculate late Quaternary strike slip rates for the faulted terraces at these two sites. Eden (1989) mapped the laterally extensive alluvial terraces in the lower Awatere Valley, and assigned a late Quaternary stratigraphy to these based on loess deposits and tephras. Little et al. (1998) and Benson and Little (2001) describe patterns of geomorphic segmentation of the fault trace, and the kinematics of surface displacement along a $27 \mathrm{~km}$ long reach of the eastern section near the South Island's east coast. They present new data on alluvial terrace ages, late Quaternary offsets, and slip rates on that structure, which they estimate to be $\sim 6 \mathrm{~mm} / \mathrm{a}$ since the late Quaternary. They also demonstrate a dramatic along-strike decrease in slip rate eastward towards the coast, where the fault bifurcates and strike-slip rates decrease to $<1.5 \mathrm{~mm} / \mathrm{a}$ in response to splaying of the fault system and the transfer of transcurrent motion into vertical-axis fault block rotations (e.g., Little and Roberts, 1997). 


\subsection{STUDY METHODS}

Active traces of the Awatere Fault were mapped between Grey River and Guide River on the eastern section and between Kennet River and Saxton River on the Molesworth section (Figure 2.2). Detailed analysis of 1:22,000 scale aerial photographs was followed by continuous field mapping of $>90 \%$ of the fault trace. Site locations were determined in the field by a Garmin E-Trek global positioning system (horizontal accuracy of $\pm 5-7 \mathrm{~m}$ ). Fault offsets of geomorphic landforms were measured at 97 sites in this area, and these are combined with three terrace riser displacements on the east bank of Grey River that were measured by Little et al. (1998). All the offset data are tabulated in Appendix A (Table A.1.), and the locations of each offset site are shown in Figure A.1. The majority of offsets identified from this study were measured in the field by projecting the displaced feature to the fault trace along the ground surface and measuring the separation with a measuring tape. At selected key localities, neotectonic offsets were surveyed using a Leica real-time kinetic global positioning system (RTK-GPS). Topographic data surrounding displaced features were contoured using the terrain modelling program Surfer v.8 (Golden Software Inc., 2002), which allow displacement calculations that take into account both the plunge of the feature and the dip of the fault plane (see Little et al., 1998). Large horizontal displacements that were identified during aerial photograph analysis were measured digitally by registering the aerial photographs within a global coordinate system/reference frame using the GIS program MapInfo. The terrace riser displacements at Grey River (sites 98, 99 and 100) were surveyed by Little et al. (1998) using a total-station electronic distance meter (EDM) theodolite.

\subsection{NEOTECTONICS OF THE AWATERE FAULT IN THE UPPER AWATERE AND ACHERON VALLEYS}

\subsubsection{Quaternary landforms and surficial deposits}

Alluvium shed off the uplifted mountains to the northwest of the Awatere Fault in the upper Awatere Valley (including the Rachel Range and the hills surrounding Mt Chisholm; see Figure 2.2) are preserved as outwash fans extending down onto the valley floor. These fans do not coalesce into a braided alluvial plain as proposed in facies models of alluvial fans (e.g., Boggs, 1995); instead they onlap 


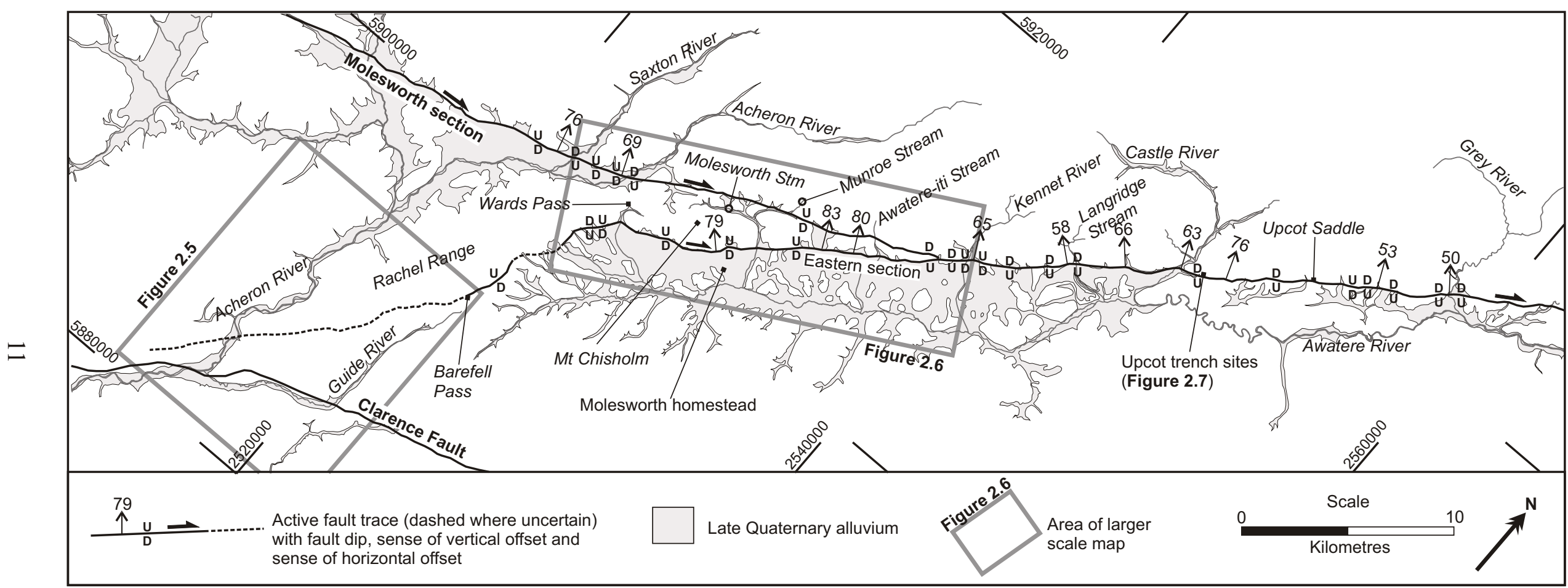

Figure 2.2 Simplified neotectonic map of the upper Awatere and Acheron Valleys showing the location and attitudes of the active Awatere Fault trace and the distribution of late Quaternary alluvium (undifferentiated). Sites mentioned in the text are labelled. 
and envelop bedrock (greywacke) promontories. In general, the fans are characterised by two distinct sets of surfaces: a higher and a lower set. The higher level of fans defines a regionally extensive horizon, that is now highly dissected. This surface is commonly $20-40 \mathrm{~m}$ above the level of active stream channels, though in rare places even higher bevelled ridges of bedrock, capped by a thin $(\sim 5 \mathrm{~m})$ cover of alluvium, occur 40-80 m above stream level. The sediment thicknesses of these higher fans are not well exposed, but appear to decrease away from the range front. In most cases, the higher fans are underlain by greywacke strath surfaces and are flanked by bedrock hillslopes (Figure 2.3), implying these sediments are only thin mantles $(<10 \mathrm{~m}$ ?). The alluvium consists of poorly sorted, angular to subrounded gravel that was deposited only a short distance from its source in the nearby ranges. The lower and less dissected set of fans consist of up to six levels, and occur at a lower topographic position than the higher set of fans. Their height is commonly less than $10 \mathrm{~m}$ above the modern stream level (Figure 2.3), and rarely as high as $20 \mathrm{~m}$ above stream level.

No suitable material was found for dating of these surfaces, but the higher set of fans may be similar in age to well-dated alluvial fans in the lower Awatere Valley that have ${ }^{14} \mathrm{C}$ ages of $21 \pm 3$ ka B.P. (Benson et al., 2001). Alluvial fans throughout the Awatere Valley similarly occur at an elevation of $>20 \mathrm{~m}$ above the modern level of tributary streams draining transversely into the Awatere River. In the lower Awatere Valley, fans at Nina Brook and Rossmore Stream are dated at $21 \pm 3$ ka B.P. (Benson et al., 2001). These fans are similar in surface morphology and height above the modern stream level to the higher set of fans in the upper Awatere Valley, suggesting the fans in both areas were deposited synchronously. If such a correlation is reasonable, then the $21 \pm 3 \mathrm{ka}$ B.P. age of the Nina Brook fan can be assumed to be the age of the high set of fans in the upper Awatere Valley.

Fluvial aggradation and incision have formed a spectacular set of alluvial terraces on the Saxton River near its junction with the Acheron River on the Molesworth section of the Awatere Fault. The highest terrace $\left(\mathrm{T}_{1}\right)$ at Saxton River is underlain by gravel that is 10-20 m thick. Lower flights of degradation terraces at Saxton River and Grey River are not as laterally extensive as terrace flights preserved in the lower Awatere Valley (e.g., Eden, 1989; Townsend, 2001), but intersect the Awatere Fault 


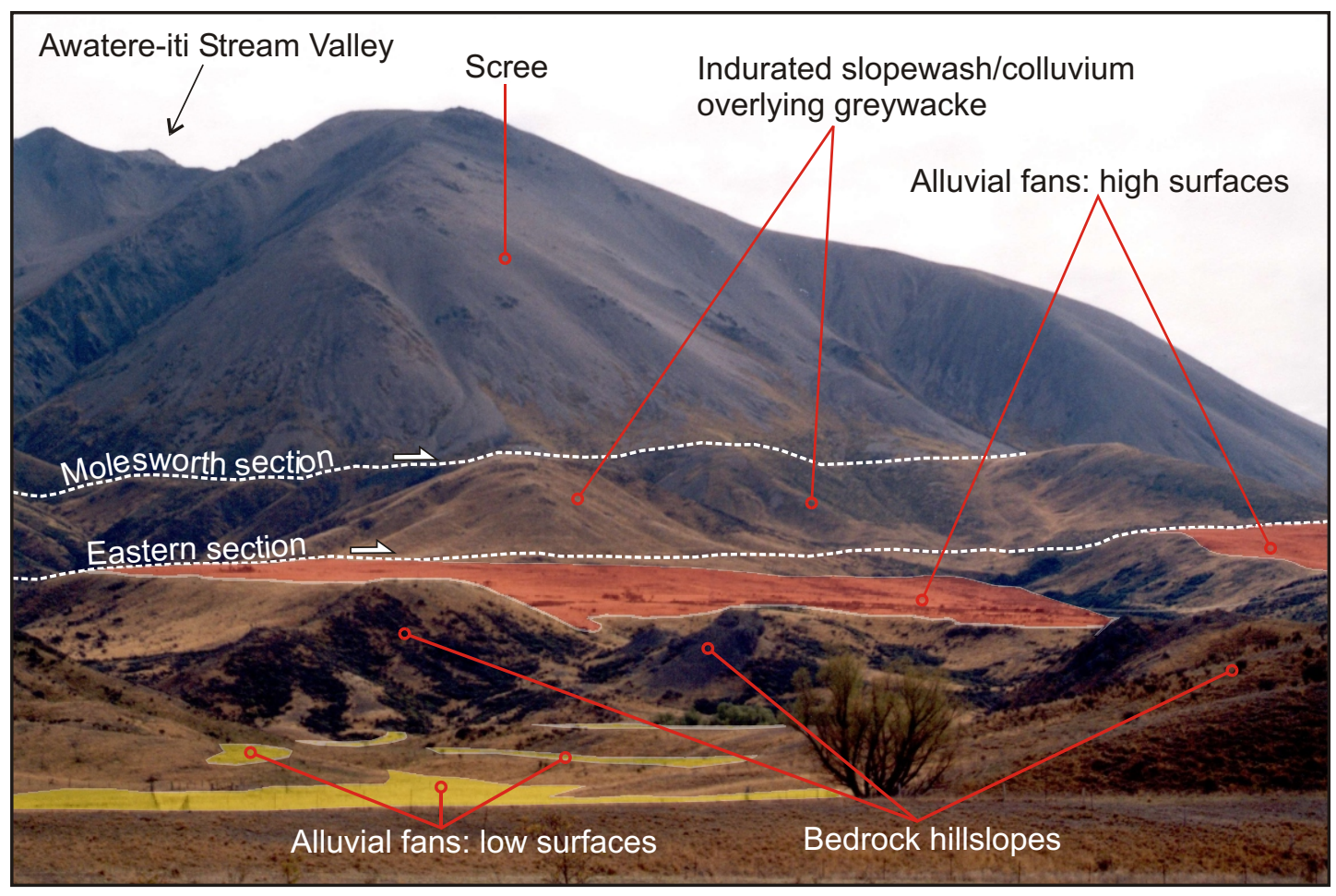

Figure 2.3 Photograph of the eastern and Molesworth sections of the Awatere Fault to the east of Awatere-iti Stream, showing several characteristic landforms of the upper Awatere Valley: steep scree slopes on the uplifted greywacke mountains, hillslopes covered by indurated slopewash and solifluction debris, remnants of high alluvial fan surfaces underlain by bedrock, low alluvial fan surfaces and modern stream levels. Alluvial fan surfaces have been accentuated. The high fan surfaces are possibly the same age as outwash fans deposited by tributary streams of the Awatere River in the lower Awatere Valley during the Last Glacial Maximum (Benson et al., 2001). The eastern section trace lies at an elevation of $\sim 1100 \mathrm{~m}$; the scree-covered peak above the Molesworth section trace is $\sim 2040 \mathrm{~m}$ high. 
and have been used to document late Quaternary fault slip on the Awatere Fault. The terrace displacements at Saxton River are described in detail in Chapter 5.

Scree slopes form much of the surface cover on the steep greywacke mountains that lie to the northwest of the Awatere Fault (Figure 2.3). The source of these scree slopes is presumed to be freeze-thaw weathering of exposed bedrock on the high peaks. This scree cover commonly obscures scarps along the Awatere Fault, especially in the region between Guide River and stream canyons at the foot of the Rachel Range in the area near to Barefell Pass. Where scree does not fully mantle the fault trace on mountainous terrain, the bedrock is typically covered by a minor (1-5 m thick) veneer of slopewash or colluvial fan deposits. Fault scarps are commonly preserved in these deposits, where they are up to $10 \mathrm{~m}$ in height.

Small (m-scale) ponds and swamps are locally found along the Awatere Fault that have formed where stream drainage has been impeded by fault scarps and shutter ridges, such as the Upcot Saddle trench site (Chapter 3). Similarly, groundwater seeps and springs were observed emanating from bedrock hillslopes in the region southwest of Wards Pass. These seeps commonly occur where the fault scarp is otherwise quite subdued.

Glacial landforms such as those described by McCalpin (1992a, 1992b) were not observed within the parts of the upper Awatere and Acheron Valleys that were mapped during this study. This suggests that this region has not been glaciated during the late Quaternary.

\subsubsection{Tectonic geomorphology of faulting}

From Grey River southwest to Wards Pass, and from Isolated Flat northeast to Kennet River (Figure 2.2), the active traces of the eastern and Molesworth sections of the Awatere Fault are defined by persistent, but locally discontinuous, scarps ranging in height from less than $1 \mathrm{~m}$ up to $15 \mathrm{~m}$. Southwest of Wards Pass, the trace of the eastern section of that fault becomes more subdued, and southwest of Barefell Pass it is poorly and discontinuously exposed (Figure 2.2). The strike of the Awatere Fault to the southwest of Grey River ranges in azimuth from $\sim 020^{\circ}$ to $\sim 100^{\circ}$. Much of the variance in fault strike is due to topographic effects, but localised fault bends exist across deeply incised valleys that are 10-100s-m wide (e.g., Little et al., 1998). 
The fault typically dips steeply to the northwest between $70^{\circ}-85^{\circ}$, as expressed by the sinuosity of the trace across stream valleys and direct measurement at rare outcrops. Dips as low as $50^{\circ}$ were measured by Little et al. (1998) at Grey River. The apparent sense of throw across the fault varies along-strike, but the sense of horizontal slip is everywhere dextral. The fault displaces stream channels, bedrock spurs, alluvial terrace risers, alluvial fan treads, hillslopes and other geomorphic features. 97 fault offsets of geomorphic landforms were measured in this area (Figure 2.4). The horizontal displacements have azimuths that range between $019^{\circ}-102^{\circ}$ and magnitude that range between $\sim 2 \mathrm{~m}$ and $\sim 180 \mathrm{~m}$ horizontally and up to $8 \mathrm{~m}$ vertically. Figure 2.4 is a frequency histogram of horizontal displacements at all the sites. These data do not show any clear modes, although 8 sites preserve horizontal displacements of $\sim 75-85 \mathrm{~m}$ that represent slip since $\sim 15 \mathrm{ka}$. This age is provided by the age of abandonment of $14.5 \pm 1.5 \mathrm{ka}$ of the oldest fluvial aggradation terrace $\left(\mathrm{T}_{1}\right)$ at Saxton River. The bedrock hillslope that forms the eastern edge of $T_{1}$ has been displaced by $76.5 \pm 15.3 \mathrm{~m}$ by the Molesworth section of the Awatere Fault (Chapter 5).

In the following section, the neotectonic features of the Awatere Fault are described systematically with respect to different regions of the fault, from east to west. The limits of these geographical regions do not necessarily relate to any geometric or mechanical segmentation of the Awatere Fault (Figure 2.2),

\section{The eastern section between Grey River and Castle River}

Through this region, the eastern section of the Awatere Fault has a mean strike of $056^{\circ}$, and cuts through steep hill country underlain by Mesozoic argillites, sandstones and conglomerates of the Torlesse Supergroup greywackes (Lensen, 1963; MacKinnon, 1983) and mid Cretaceous basalt of the Lookout Volcanics (Grapes et al., 1992; Baker et al., 1994). In this region, the Awatere River is confined to a gorge cutting into these Mesozoic basement formations, and has not deposited a significant alluvial sequence near to the fault. The active fault cuts through a late Quaternary cover that consists chiefly of hillslope, landslide and thin alluvial fan material deposited on greywacke and basalt strath surfaces. The fault scarps of the eastern section in this region are mostly well-preserved, uphill-facing scarps up to $10 \mathrm{~m}$ high. These scarps are preserved across the older (higher) set of alluvial fans and hillslopes, as well as across more recent alluvial fans that flank the 


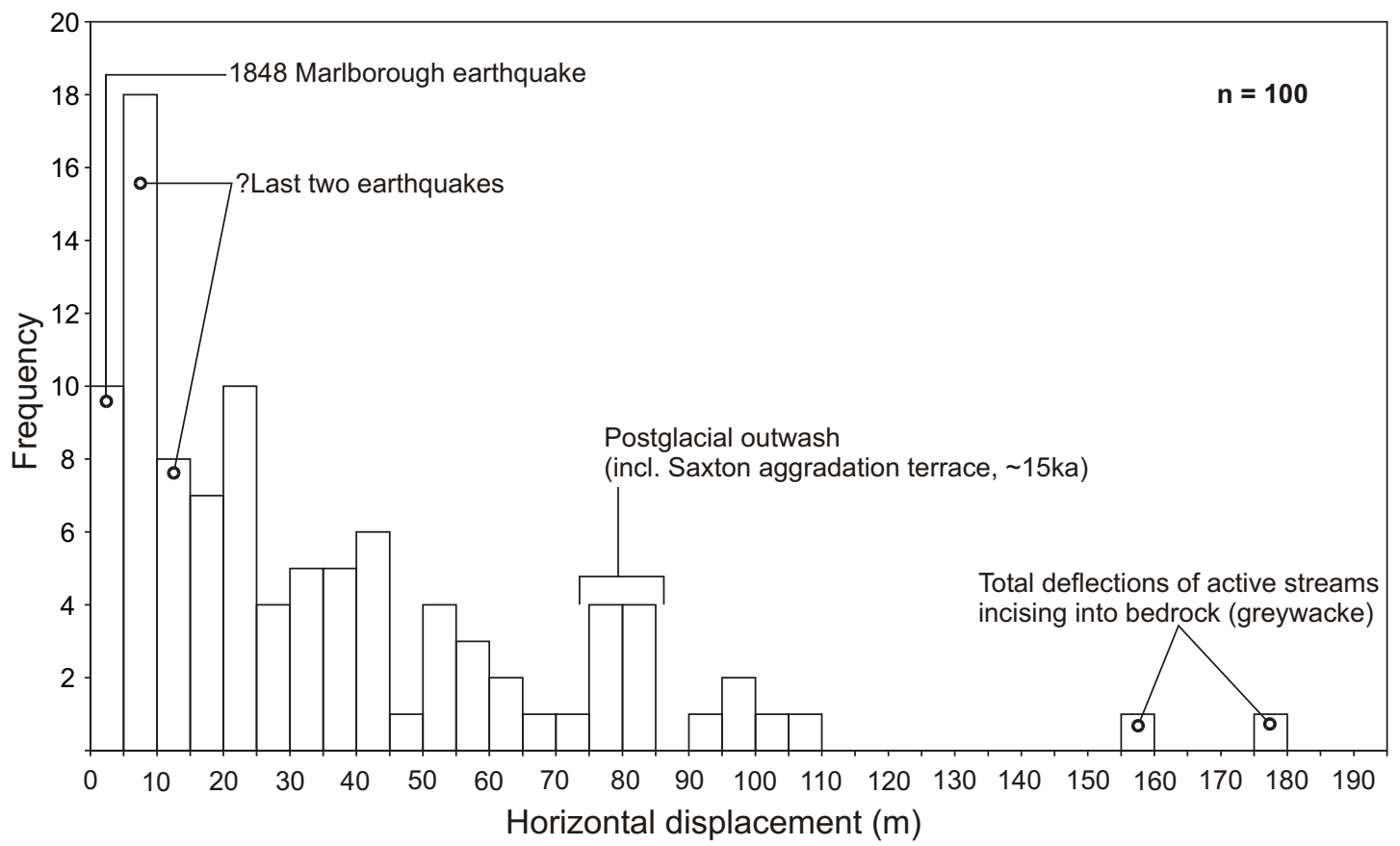

Figure 2.4 Histogram of 100 late Quaternary horizontal displacements along the Awatere Fault (west of Grey River), compiled from this study and Little et al. (1998). Slip data are grouped into $5 \mathrm{~m}$ intervals. 
currently active streams. The excellent preservation of the fault scarps here is presumably due at least in part to the recent rupture of this part of the Awatere Fault during the $\mathrm{M}_{\mathrm{w}} \sim 7.51848$ Marlborough earthquake. Nineteen displaced geomorphic features were measured in this region; these are chiefly bedrock channels and spurs, and have a mean azimuth of horizontal separation of $063^{\circ}$. In this region, alluvial terrace treads, alluvial fan surfaces and rare bedrock channels and hillslopes preserve both horizontal and vertical slip. Vertical displacements of 0.8-6 $\mathrm{m}$ of these features are largely upthrown to the southeast, and have ratios of vertical to horizontal slip between 0.01 and 0.63 .

\section{$\underline{\text { The eastern section between Castle River and Wards Pass }}$}

Through this region, the eastern section has a mean strike of $\sim 055^{\circ}$. The local fault strike varies smoothly along this reach of the fault between $032^{\circ}$ and $084^{\circ}$. Across this part of the Awatere Valley lie a laterally extensive cover of late Quaternary alluvial fans (the high terrace surfaces referred to earlier) that are punctuated by knolls of Torlesse greywacke. The active fault trace typically lies at or near the slope break between the uplifted greywacke mountains to the northwest and the downthrown fan alluvium to the southeast. Prominent scarps $<15 \mathrm{~m}$ high are formed across bedrock hillslopes and spurs, both levels of alluvial fans (see earlier description), and vegetated slopewash and landslide deposits. These become subdued, however, where the fault crosses deeply-incised valleys or active scree slopes shed from the $>2000$ m-high peaks on the northwest side of the fault. Across several deeply-incised valleys, such as the Kennet River and Langridge Stream valleys (Figure 2.2), the fault apparently bifurcates upwards to form at least two subparallel, discontinuous traces that are $<500 \mathrm{~m}$ apart. Forty displaced geomorphic features were measured along this part of the eastern section. Horizontal displacements of landforms range between $4.2 \pm 2 \mathrm{~m}$ and $179 \pm 36 \mathrm{~m}$, and have a mean azimuth of horizontal separation of $057^{\circ}$. Planar geomorphic features such as alluvial fans and hillslopes record vertical displacements of 0.3-8 $\mathrm{m}$ at 12 sites, and the majority of these displaced features are upthrown to the northwest. The ratio of vertical to horizontal slip of these displacements range between 0.02 and 0.4 . 


\section{The eastern section between Wards Pass and Guide River}

In the vicinity of Wards Pass, the eastern section swings to a more northerly strike, defining a $\sim 20^{\circ}$ restraining bend in the surface trace. The mean strike of the Awatere Fault between Wards Pass and Barefell Pass is $040^{\circ}$, and the sinuous nature of the surface trace suggests this part of the fault has a dip of $\sim 50^{\circ}$, somewhat shallower than the $70-80^{\circ}$ dip observed further east. Because of the subdued and obscured nature of the fault trace in the region southwest of Wards Pass, only 8 displacements of geomorphic landforms were measured: 6 deflected channels, 1 displaced spur and 1 displaced terrace. Horizontal displacements of these landforms range between $4.1 \pm 0.5 \mathrm{~m}$ and $33.4 \pm 1.5 \mathrm{~m}$, and the three measured vertical displacements range from $0.9 \pm 0.2 \mathrm{~m}$ to $3.8 \pm 1.8 \mathrm{~m}$. Two of the three vertical offsets are upthrown on the north side of the fault. The mean strike of the horizontal separations is $040^{\circ}$, and the ratios of vertical to horizontal slip range from 0.03 for a displaced terrace (site 20) to 0.43 for a deflected channel (site 11).

To the southwest of Wards Pass, the Awatere Fault trace is difficult to define. In this region, the eastern section of the fault is marked by discontinuous scarps up to $\sim 5 \mathrm{~m}$ high, that have subdued topographic expression relative to scarps further to the northeast. The scarps to the southwest of Wards Pass have variable facing directions; uphill (west) facing scarps and ridge rents are formed across hillslopes that consist chiefly of slopewash and colluvium, and downhill (east) facing scarps are formed across alluvial fans that were shed from the Rachel Range. Because these scarps are not as well-preserved as those mapped further to the northeast, tracing the fault was difficult in this region. At several sites, prominent scarps and displacements were locally well preserved (e.g., sites 6, 9, 11, 17, 18, 20 and 22; Table A.1), and these features were used as tie-points from which the fault trace was projected to the north and south, across the flanks of the Rachel Range. Prominent topographic steps, chiefly uphill-facing notches and troughs across spurs and hillslopes, are common in this region, especially along the projected fault trace. These features were therefore mapped as scarps of the Awatere Fault where they lie on this projection.

Seeps and springs were also mapped to be expressions of the Awatere Fault across the hillslope immediately to the southwest of Wards Pass, between sites 22 
and 24 (Figure A.1). Along this particular reach of the fault, the springs and seeps, as well as the slope break between alluvial fans and bedrock promontories, project along the same strike as the fault toward the fault offsets at sites 17, 18, 20 and 22 . At several of these springs, contacts between greywacke and colluvium/slopewash deposits were observed, with the groundwater flowing from within the hillslope deposits on the uphill side. This suggests there is a discontinuity or step in the bedrock surface that is impeding the groundwater flow, or, alternatively, that there is an impermeable horizon within the hillslope deposits. These observations suggest these springs lie where groundwater flow down the hanging wall hillslopes is impeded either by offset of the bedrock, or the presence of impermeable deposits (gouge) within the fault zone. Where they could be reasonably extrapolated along the trend of the fault from further southwest, these springs and seeps to the southwest of Wards Pass were mapped as expressions of the Awatere Fault.

Another area of uncertainty is $\sim 5 \mathrm{~km}$ northeast of Barefell Pass, where the fault cuts across several deeply incised canyons that are tributaries of the Awatere River. Scree slopes on the steep canyon walls obscure the trace of the fault along a 2-3 km stretch here. Between these canyons, bedrock spurs are incised along the inferred fault trace into sharp, uphill-facing notches. These notches lie at a prominent slope break between the steep hillslopes of the Rachel Range to the west and the more gently sloping spurs to the east. These features lie at a similar height to the downhill-facing fault scarps and displacements at sites 9 and 11, and together define an $\sim 045^{\circ}$ lineament that is similar to the fault's $040^{\circ}$ trend closer to Wards Pass to the northeast. These observations suggest the notches on these spurs may be remnant fault scarps, but that associated geomorphic displacements have been obliterated by erosion of the steep bedrock slopes on either side of these notches.

Southwest of Barefell Pass is the Guide River catchment (Figure 2.5), a deeply incised valley that is bounded on the west side by steep slopes $\left(<40^{\circ}\right)$ that are mantled with scree shed from the Rachel Range. The eastern section of the Awatere Fault can be traced as far southwest as Barefell Pass, but beyond this the fault does not form obvious scarps across the scree-covered flanks of the Rachel Range. The conspicuous alignment of a series of $>30$ notched spurs similar to those described above suggests the Awatere Fault probably continues through this valley, though only one of these spurs is obviously displaced (site 2). These notches are generally 


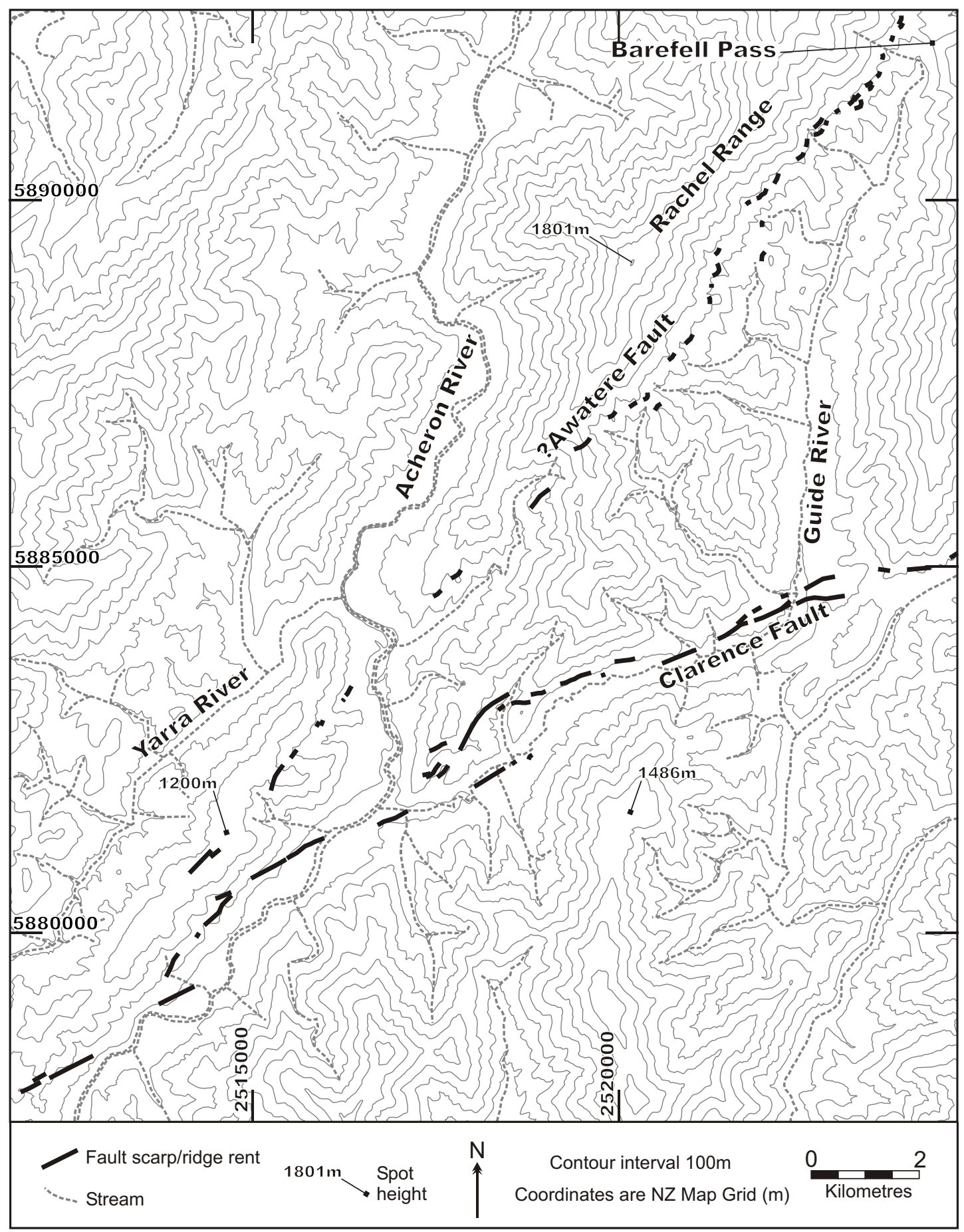

Figure 2.5 Map of the area surrounding the confluence of the Guide and Acheron Rivers. While the Awatere Fault is not as well-preserved in the Guide River Valley as in the Awatere Valley, a conspicuous line of notched ridges extends southwest from Barefell Pass to within $500 \mathrm{~m}$ of the Clarence Fault, suggesting these two faults may join in this area. Scarps of the Clarence Fault are from Kieckhefer (1979). 
sharp, uphill-facing features, defined by abrupt breaks in the crests of the spurs with up to $\sim 5 \mathrm{~m}$ of relief. The crests of these spurs consist of a thin $(\sim 1 \mathrm{~m})$ cover of colluvium that overlies steeply northwest-dipping Torlesse greywacke. The spurs have shallow inclinations $\left(0-20^{\circ}\right)$ compared to the steeper scree slopes, and thus protrude from beneath the scree cover at a mean elevation between 1300 and $1400 \mathrm{~m}$. These spurs define a distinctive topographic lineament that approximately corresponds to the height at which the fault was mapped near Barefell Pass, and has a mean trend of $\sim 040^{\circ}$, which is the same as the mean strike of the eastern section trace to the northeast of Barefell Pass. The lineament defined by these spurs was able to be traced, both on aerial photographs and during field mapping, southwest from Barefell Pass to near the confluence of the Guide and Acheron Rivers. Because of the similarities in the trend and topographic position of these features compared to the eastern section trace to the northeast of Barefell Pass, this lineament of notched spurs is assumed to be the southwestern expression of the eastern section of the Awatere Fault. In the Acheron River valley, uphill-facing notches incised into bedrock spurs were mapped across the hills to the northeast of Acheron River, and downhill (south) facing scarps $\sim 1-2 \mathrm{~m}$ in height were mapped along a flat-topped ridge that forms a watershed between the Acheron and Yarra Rivers (Figure 2.5).

$\underline{\text { The Molesworth section between Isolated Flat and Kennet River }}$

McCalpin (1996a) mapped the Molesworth section between Lake Tennyson and Acheron River, documenting a mean fault strike between of $072^{\circ}$, that is $\sim 15-20^{\circ}$ clockwise from the mean strike of the eastern section. The Molesworth section includes several small transtensional basins that are associated with a locally high ratio of vertical to horizontal slip (McCalpin, 1996a). Isolated Flat is the easternmost of these basins, and is infilled with late Quaternary alluvium deposited by the Saxton and Acheron Rivers (Figure 2.2). The Molesworth section of the Awatere Fault lies at the northern margin of this basin, and the active fault is marked by predominantly south-facing scarps that are typically 10-20 m high where they cut across late Quaternary alluvial fans. To the northeast of Isolated Flat, the Molesworth section is marked by prominent, continuous and well-preserved uphill (north) facing scarps. Here the fault primarily cuts across hillslopes that consist either of slopewash and colluvium, or relatively young flights of late Quaternary alluvial fans. Fault 
displacements of geomorphic landforms were measured at 31 sites along the Molesworth section between Saxton River and Kennet River. These landforms were typically channels and spurs, though displacements of alluvial terrace risers were measured on the east bank of Saxton River (see Chapter 5) and at Acheron River. Horizontal displacements range from $2.2 \mathrm{~m}$ for an ephemeral channel incised into the hillslope between the Saxton and Acheron Rivers, to $\sim 155 \mathrm{~m}$ for deflection of a bedrock-lined channel west of Kennet River. Together, these 31 displacements have a mean azimuth of horizontal separation of $\sim 065^{\circ}$. Vertical displacements of fluvial terrace treads and alluvial fan surfaces range from $0.4 \mathrm{~m}$ to $5.5 \mathrm{~m}$. The sense of throw across the Molesworth section along Isolated Flat is predominantly upthrown to the north, and ratios of vertical to horizontal slip on the fault from Isolated Flat to Kennet River vary between 0.02 and 0.14 .

\section{The Mt Chisholm block}

The Mt Chisholm block (McCalpin, 1996a) is bounded by the active traces of both the eastern and Molesworth sections. This region consists of a rhomboidal mountain block, sculpted into an anomalously flat-topped series of hills up to $\sim 1500$ $\mathrm{m}$ in elevation. Where exposures exist, the bedrock of the Mt Chisholm block is found to consist of fractured Torlesse greywacke. These hills are split by a complex system of topographic scarps, comprised of sinuous ridge rents, sidehill and uphillfacing scarps, and crestal horsts and grabens (Figure 2.6). Most of the scarps within the Mt Chisholm block are uphill-facing, and have a mean spacing of $175 \pm 20 \mathrm{~m}$. The spacing between individual scarps ranges from 20-30 m between scarps on the crest of these hills to $\sim 700 \mathrm{~m}$ between scarps on the hillslopes. Scarps on the crests of the ridges are mostly south-facing. The most continuous scarps, generally found on ridge crests or flat-lying alluvial fans, are up to $1000 \mathrm{~m}$ long and up to $8 \mathrm{~m}$ high, whereas the more discontinuous scarps and ridge rents across the steep hillslopes flanking this faulted block are typically 50-100 $\mathrm{m}$ long and less than $1 \mathrm{~m}$ high.

These scarps may not have formed by coseismic surface rupture through the Mt Chisholm block, but possibly by non-seismic, gravitational hillslope failure. Only one horizontal displacement was measured during mapping of this block (site 25), which does not provide definitive evidence in favour of these features being fault scarps. As these scarps occur across a narrow block that is bounded by two 


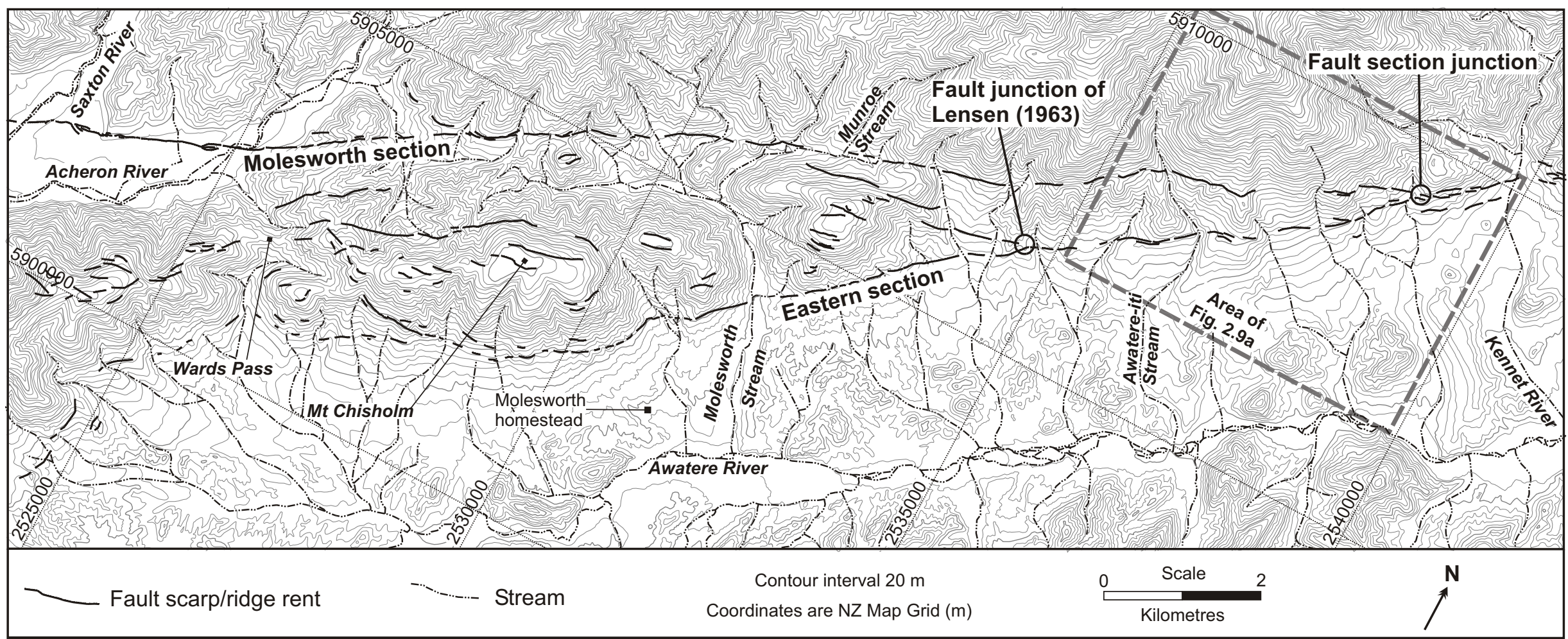

Figure 2.6 Map showing the distribution and abundance of prominent fault scarps within the fault junctions region (the Mt Chisholm block), between the active traces of the eastern and Molesworth sections of the Awatere Fault. This map shows the location of the fault section junction between the eastern and Molesworth sections as mapped by Lensen (1963), and the refined location of this junction based on new field mapping and aerial photo analysis. 
principal sections of an active strike-slip fault, and are morphologically indistinguishable from fault scarps and rents along the Awatere Fault, it is plausible that these features are fault scarps.

The fault scarps within the Mt Chisholm block have a bimodal distribution of strikes that are both oblique and subparallel to the strikes of the principal faults bounding the block. Between Awatere-iti Stream and Wards Pass, the eastern section has a mean strike of $\sim 055^{\circ}$, whereas the Molesworth section has a mean strike of $\sim 065^{\circ}$ between Acheron River and Kennet River. Within the Mt Chisholm block, one set of scarps has a mean strike of $\sim 085^{\circ}$, that is $20-30^{\circ}$ clockwise from the strikes of the adjacent bounding faults. Another set of scarps has a mean strike of $\sim 062^{\circ}$, which approximately bisects the angle between the strikes of the eastern and Molesworth sections in this area. The sense of slip across these faults appears to be dextral-oblique, on the basis of dextral displacement of a channel at site 25 .

\section{$\underline{\text { Late Quaternary slip rates on the eastern section }}$}

In the preceding section, the highest set of alluvial fans in the upper Awatere Valley was argued to have been deposited coevally with the $21 \pm 3$ ka B.P. Nina Brook fan in the lower Awatere Valley (Benson et al., 2001). If this correlation is reasonable, then this age may be used to estimate the slip rate at other sites in the upper Awatere Valley where fans are displaced by the Awatere Fault. At site 92, near Upcot Saddle (Table A.1), the well-defined edge of a high fan is dextrally offset by $117.5 \pm 15 \mathrm{~m}$. If this fan was deposited at $21 \pm 3 \mathrm{ka}$, then a lateral slip rate of 5.6 $\pm 1.1 \mathrm{~mm} / \mathrm{a}$ is inferred. This is indistinguishable from the $6 \pm 2 \mathrm{~mm} / \mathrm{a}$ calculated for lateral displacements on the Nina Brook fan surface in the lower Awatere Valley (Benson et al., 2001), and to the $5.5 \pm 1.5 \mathrm{~mm} / \mathrm{a}$ calculated for lateral displacements of a flight of faulted terrace risers at Saxton River on the Molesworth section (Chapter 5).

At a deflected stream channel between Upcot Saddle and Castle River (Figure 2.2), a fault-orthogonal paleoseismic trench was excavated (see Chapter 3 ). ${ }^{14} \mathrm{C}$ dating of the sediments exposed in this trench provides age data that may be used to estimate strike slip rates for displacement of this channel. This channel has been deflected by dextral displacement of a bedrock spur, and the swamp deposits that 
have accumulated against the $<10 \mathrm{~m}$ high shutter ridge scarp should have accumulated after displacement of the spur began to deflect the channel. The trench at this site was 4-5 m deep, and a peat horizon exposed near the base of the trench yielded a calibrated ${ }^{14} \mathrm{C}$ age of $5310-5590$ cal. years B.P. The channel has been deflected by $44.6 \pm 12.8 \mathrm{~m}$ (Figure 2.7 ), which yields a slip rate of $8.2 \pm 2.4 \mathrm{~mm} / \mathrm{a}$ with the age from the trench. This trench was not excavated into bedrock that is presumed to underlie the swamp deposits, and therefore the age of this peat will postdate the formation of the swamp. Consequently, this slip rate estimate should be considered a maximum rate.

\subsection{DISCUSSION}

\subsubsection{Relationships between fault strike and the amount and sense of vertical displacement}

The sense of throw and the ratio of vertical to horizontal $(\mathrm{V}: \mathrm{H})$ slip across a northwest-dipping dextral-slip fault should, assuming rigid behaviour of the fault blocks, be controlled by the angle between the fault surface and the local azimuth of relative fault block motion. According to this model, an anticlockwise deviation of the scarp azimuth relative to the mean fault strike should result in scarps that are upthrown to the north (reverse throw), while a clockwise deviation would produce scarps that are upthrown to the south (normal throw). Along the coastal part of the Awatere Fault, Little et al. (1998) and Benson and Little (2001) reported nonsystematic variations in the sense of throw across that fault with changes in the fault strike that do not agree with this rigid model of fault slip. In the upper Awatere Valley, the mean azimuth of horizontal displacement is $057^{\circ}$ for the eastern section of the Awatere Fault. Parts of the eastern section trace that are upthrown on the northwest side (reverse throw) range in strike from $048^{\circ}$ to $074^{\circ}$, while sections that are upthrown on the southeast side (normal throw) range in strike from $041^{\circ}$ to $102^{\circ}$. Throw sense therefore appears to be independent of fault strike on the eastern section, suggesting non-rigid behaviour of these fault blocks.

The sense of throw along the studied part of the Molesworth section does vary systematically with fault strike. McCalpin (1996a) calculated a mean strike of $072^{\circ}$ for the Molesworth section between Acheron River and Lake Tennyson. This study focused on the area to the east of McCalpin's area, along the eastern end of this 


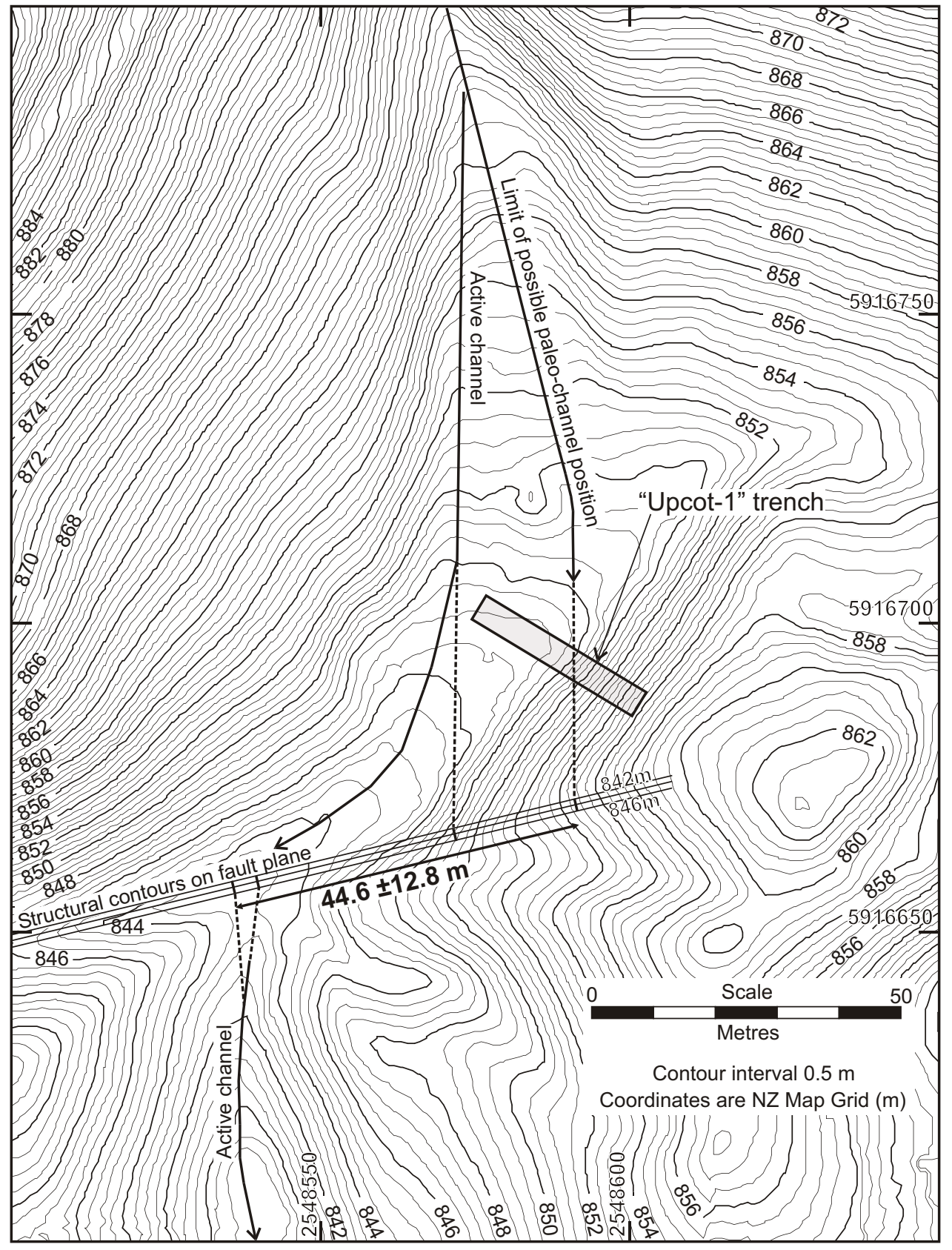

Figure 2.7 Map of the deflected channel and displaced spur at the Upcot Saddle trench site, surveyed using an RTK-GPS. Excavation of the Upcot-1 trench exposed carbonaceous horizons near the base of the trench (see Chapter 3) that provide a minimum age for accumulation of swamp deposits against the shutter ridge scarp. Measurement of the deflection of the channel, in combination with the ${ }^{14} \mathrm{C}$ data from the Upcot-1 trench, suggests a maximum slip rate of $8.2 \pm 2.4 \mathrm{~mm} /$ a since the mid-Holocene. 
fault section from Saxton River to Kennet River. Here, measured geomorphic displacements have a mean strike of $067^{\circ}$. The scarps along this part of the Molesworth section trace that are upthrown on the northwest side range in strike from $062^{\circ}$ to $081^{\circ}$, while scarps that are upthrown on the southeast side range in strike from $048^{\circ}$ to $062^{\circ}$. These observations would seem to be at least partially consistent with a rigid block model of fault slip such as that outlined above. In detail, however, the throw variations could only be explained if the Awatere Fault has a southeast dip. The observed pattern of fault trace deviation across topography, however, suggests a generally northwest dip across this region. This discrepancy may be due to upward bifurcation of the fault zone into multiple surface traces, which could result in a locally variable sense of throw across a series of near-surface fault slivers. Evidence for this includes a shallow basin, with $\sim 5 \mathrm{~m}$ of fine-grained sediment at its deepest point, that has formed along the fault on the highest terrace at Saxton River. Alternatively, non-rigid behaviour of the fault blocks may include plastic deformation of near-surface sediments by bulging and/or folding - processes that will strongly affect the local sense of throw on the adjacent fault.

For rigid blocks, the ratio of vertical to horizontal (V:H) slip should change predictably with local fault strike. Theoretically, as the angle of obliquity between the fault strike and the azimuth of local fault block transport increases, the magnitude of vertical slip should increase relative to horizontal slip. Figure $2.8 \mathrm{a}$ and $\mathrm{b}$ plot the $\mathrm{V}: \mathrm{H}$ ratios for sites on the eastern and Molesworth sections, respectively, where both vertical and horizontal slip were measurable. Also plotted are the $\mathrm{V}: \mathrm{H}$ ratios predicted by a rigid block scarp model of faulting (dotted lines). These ratios were plotted assuming fault dips of $50^{\circ}, 65^{\circ}$ and $80^{\circ}$ to the northwest, which approximates the range of fault dips measured for the Awatere Fault in this study. The azimuths of mean fault block transport are calculated to be $057^{\circ}$ for the eastern section and $067^{\circ}$ for the Molesworth section. The shaded regions show the fields of $\mathrm{V}: \mathrm{H}$ ratios for faults dipping $>0^{\circ}$ and $<90^{\circ}$ to the northwest.

Over half the $\mathrm{V}: \mathrm{H}$ ratios for geomorphic displacements measured on the eastern section show a consistent southeast-up sense of throw, with $\mathrm{V}: \mathrm{H}$ ratios between $0-0.1$, regardless of the local transport azimuth. This pattern would not be predicted by the rigid block model of faulting used here, and provides further 

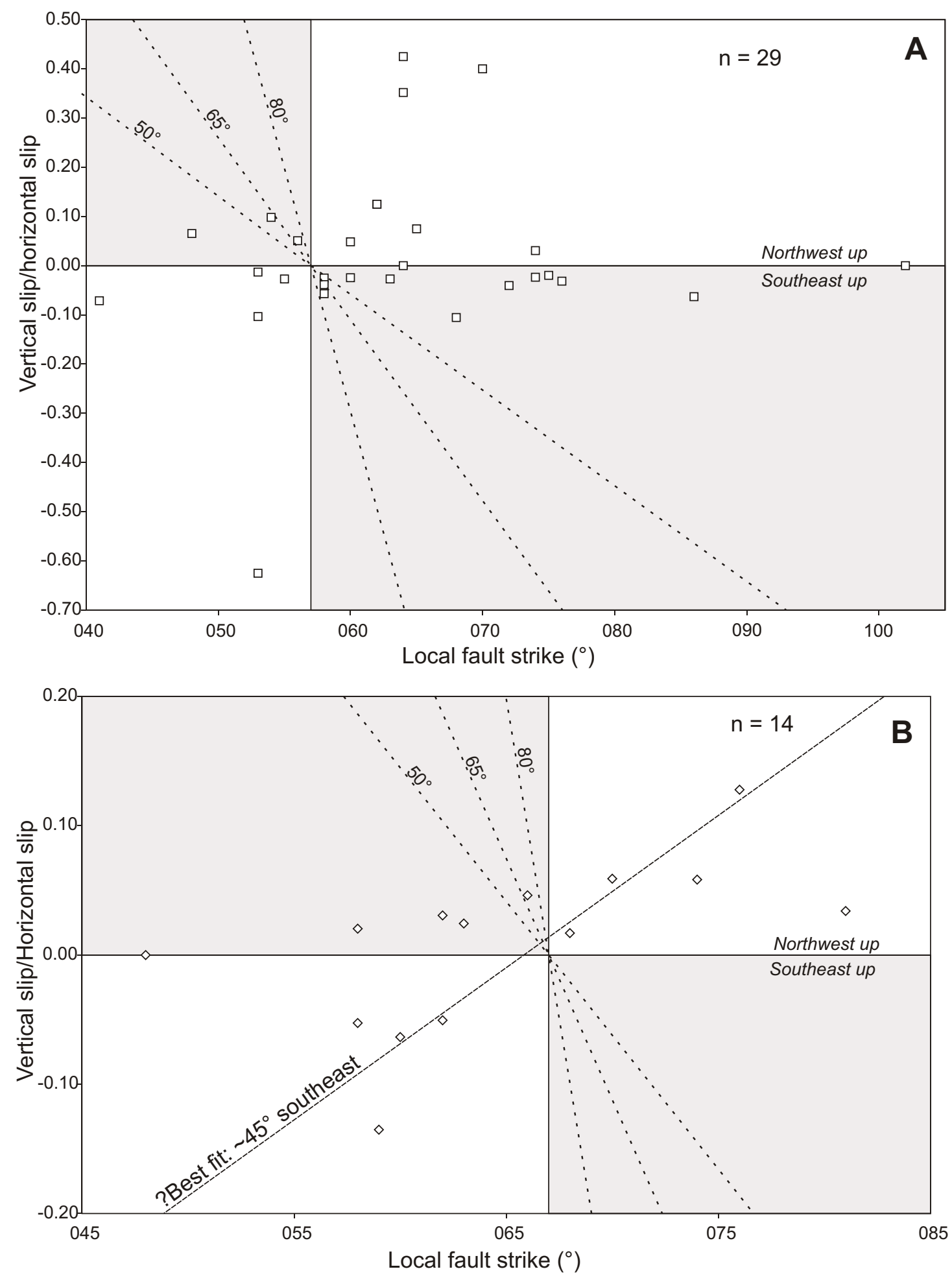

Figure 2.8a-b Ratios of vertical to horizontal (V:H) slip for displaced geomorphic features measured on the Awatere Fault between Grey River and Saxton River, plotted against the local fault strike. A negative $\mathrm{V}: \mathrm{H}$ value indicates the southeast side of the fault is upthrown. Dotted lines and shaded regions indicate $\mathrm{V}: \mathrm{H}$ ratios predicted by a rigid block model of faulting for a northwest-dipping fault plane (e.g., Benson and Little, 2001). This model assumes mean azimuths of fault block transport of $057^{\circ}$ for the eastern section and $067^{\circ}$ for the Molesworth section. The dotted lines represent the range of fault dips measured for the Awatere Fault. (A) Data for the eastern section; (B) data for the Molesworth section. 
evidence that the sense and magnitude of throw across the eastern section of the Awatere Fault are independent of fault strike. Data measured on the Molesworth section do show systematic variations in $\mathrm{V}: \mathrm{H}$ ratio with changing fault strike, though the pattern is not explicit. This pattern would partially fit a model with a fault plane that strikes $\sim 065^{\circ}$ and dips $\sim 45^{\circ}$ to the southeast, as shown by the dashed line in Figure $2.8 \mathrm{~b}$, though this the data show variations that are not completely consistent with this model. Lateral trimming of horizontal displacements might cause an apparent enhancement of V:H ratios (e.g., McCalpin, 1996a). Alternatively, nearsurface bifurcation of the fault, or non-rigid deformation of unconsolidated sediments both within the fault zone and near to the ground surface may also contribute to natural patterns that do not fit a rigid block model.

In general, the data for both the eastern and Molesworth sections of the Awatere Fault show that both $\mathrm{V}: \mathrm{H}$ ratios and along-strike variations in the sense of throw cannot be entirely explained with a simple rigid block model of oblique-slip faulting. This implies that some component of fault-normal slip is accommodated by off-fault deformation mechanisms. Benson and Little (2001) observed similar V:H patterns to those described here, and invoked structures such as blind faults, folds and pop-ups to accommodate a significant portion of dip-slip deformation away from the main fault plane along the coastal $27 \mathrm{~km}$ of the Awatere Fault. Similar off-fault structures were not obvious along most of the Awatere Fault in this study, though the abundant scarps within the Mt Chisholm block suggest significant distributed deformation away from the principal fault sections here. Such structures may therefore contribute to apparent discrepancies between the fault attitudes and the sense and magnitude of throw. Alternatively, the locally anomalous senses of throw may be an artefact of the sparse distribution of geomorphic features that preserve vertical displacements. Of the 100 measured displacements presented in this study, vertical offsets were only observed at 47 sites. This number of data points may not be a sufficiently large sample to statistically document the kinematics of oblique-slip faulting along this structure.

\subsubsection{Location of the junction between the eastern and Molesworth sections}

Previous mapping of the Molesworth section trace suggested this fault intersects with the eastern section in a tributary valley of the Awatere River, $\sim 2.5 \mathrm{~km}$ 
west of Awatere-iti Stream (Lensen, 1963; see Figure 2.6). New analysis of lowaltitude aerial photographs (1:22,000 scale) and detailed field mapping of this area show that the Molesworth section clearly extends $\sim 5 \mathrm{~km}$ further to the northeast of this previously-mapped termination. To the east of Munroe Stream, the fault is expressed by prominent, uphill-facing scarps with up to $5 \mathrm{~m}$ of relief that displace bedrock spurs and channels that have incised into vegetated scree, colluvium and greywacke bedrock (e.g., Figure 2.9). Horizontal displacements of channels range from $\sim 13 \mathrm{~m}$ for an ephemeral channel incised into vegetated scree/colluvium at site 66 to $\sim 155 \mathrm{~m}$ total deflection of an active channel incised into greywacke bedrock at site 63. The scarp of this easternmost part of the Molesworth section cuts down the hillslope to the east of the site shown in Figure $2.9 \mathrm{~b}$, and coalesces with the $055^{\circ}$ striking eastern section of the Awatere Fault at a site approximately $1.2 \mathrm{~km}$ southwest of Kennet River. This is the intersection between the two principal sections of the Awatere Fault.

\section{Geometry of the fault junctions region}

The fault junctions region is a narrow, elongate, fault-bounded wedge (Figure 2.10). The two fault sections differ in strike by $10-15^{\circ}$ across the fault junctions region. Uncertainties and local variations in the strike of fault scarps near the junction mean that this angle cannot be measured more precisely than $\pm 5^{\circ}$. To the west of the fault intersection point, the two faults are sub-parallel to one another, and therefore overlap with each other, for a distance of $\sim 15 \mathrm{~km}$. At the site of Figure 2.9, the fault-orthogonal width between the two fault sections is $\sim 500 \mathrm{~m}$; where Molesworth Stream crosses the faults, $7.5 \mathrm{~km}$ to the west of the site in Figure 2.9, they are spaced $2.0 \mathrm{~km}$ apart. The two sections diverge rapidly westward from one another at a point approximately $3 \mathrm{~km}$ to the west of Wards Pass. This coincides with the western edge of the internally deformed Mt Chisholm block, and is here taken as the western boundary of the fault junctions region (Figure 2.6).

Implications for possible segmentation of earthquake ruptures on the Awatere Fault in the upper Awatere Valley

The geometry of the fault junctions region may provide some insight into the rupturing behaviour of the Awatere Fault. Observations of the surface rupture and 

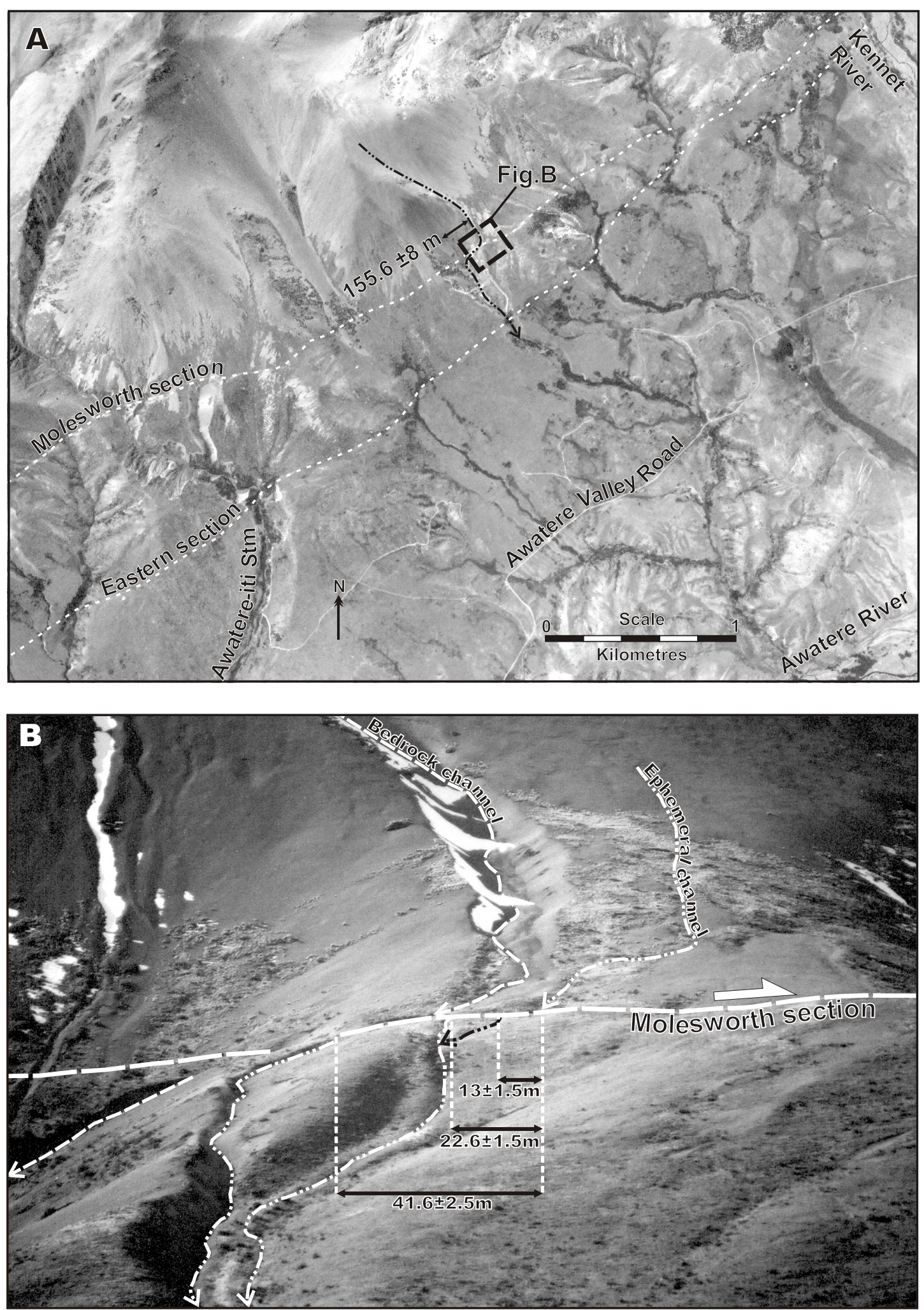

Figure 2.9a-b (A) Aerial photograph of the intersection between the eastern and Molesworth sections of the Awatere Fault. This feature is a low-angle intersection at a point $\sim 1.2 \mathrm{~km}$ west of Kennet River. The deflected channel at site 63 is emphasised. (B) Oblique photograph of geomorphic displacements across the Molesworth section $2.5 \mathrm{~km}$ to the west of Kennet River. At this site, displacements between $\sim 13$ and $\sim 155 \mathrm{~m}$ are preserved that lie several kilometres beyond the previously mapped eastern termination of the Molesworth section. 


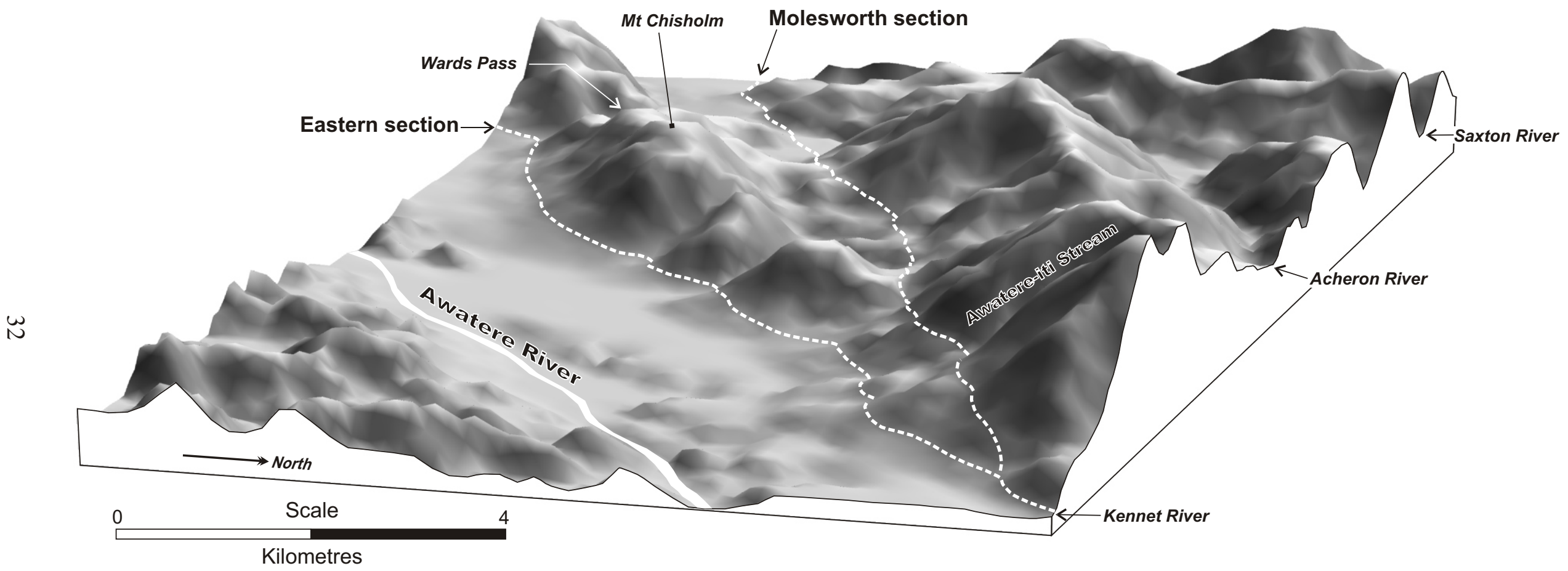

Figure 2.10 Digital terrain model of the fault junctions region between the eastern and Molesworth sections of the Awatere Fault. The two fault sections strike nearly parallel to one another on either side of Mt Chisholm, bounding a narrow, 100 's-m to 1000 's-m wide fault sliver, and intersect each other with a relatively low angle $\left(\sim 10-15^{\circ}\right)$ near Kennet River. 
slip distribution of the $M_{w} 7.31992$ Landers and the $M_{w} 7.41999$ Izmit strike-slip earthquakes suggest limiting parameters for the geometry of step-overs and bends along strike-slip faults that appear to arrest earthquake rupture propagation. Both these two earthquake ruptures only propagated across step-overs that are less than 5 km in width (e.g., Sieh et al., 1993; Spotila and Sieh, 1995; Zachariasen and Sieh, 1995; Barka et al., 2002; Langridge et al., 2002) and across fault bends that are less than $25^{\circ}$ (e.g., Hartleb et al., 2002). These are similar to results from global observations of historical earthquakes (e.g., Barka and Kadinsky-Cade, 1988; Lettis et al., 2002), and two-dimensional modelling of stress transfer across fault steps (e.g., Harris and Day, 1993). These studies suggests that $5 \mathrm{~km}$ may be a critical stepover width and $30^{\circ}$ may be a critical fault bend angle across which dynamic ruptures cannot jump.

Comparing the observed behaviour of the Landers and Izmit earthquake ruptures to the geometry of the intersection between the Molesworth and eastern sections of the Awatere Fault suggests this geometrical feature on the Awatere Fault may not significantly impede rupture propagation. The angle between the two fault sections is $10-15^{\circ}$, which is significantly less than the critical angle of $25-30^{\circ}$ estimated by Barka and Kadinsky-Cade (1988) and Hartleb et al. (2002). The fault junctions region between the eastern and Molesworth sections is $3 \mathrm{~km}$ wide at its widest point along a line southeast from Isolated Flat through Wards Pass, which is within the $\sim 5 \mathrm{~km}$ limit calculated by two-dimensional modelling of fault steps (Harris and Day, 1993) and observations of rupture patterns of global historical earthquakes (Lettis et al., 2002). The width of the Mt Chisholm block is also the same as step-overs that were pervasively ruptured during both the Landers (Zachariasen and Sieh, 1995) and the Izmit (Barka et al., 2002) earthquakes. This inference that the junction between the eastern and Molesworth sections might not significantly impede rupture propagation is in contrast to previous suggestions that this junction may have acted as a barrier to the propagation of historical and paleoearthquake ruptures, including the 1848 event (e.g., Grapes et al., 1998; Benson et al., 2001).

Faults mapped within step-over regions along the dextral-slip Landers and Izmit earthquake ruptures show that stress transfer across these step-overs was 
accommodated by rupture of closely spaced (sub-metre to kilometre-scale spacing) normal-oblique and dextral-slip cross faults that were oriented at an oblique angle $\left(\sim 20-40^{\circ}\right)$ from the main faults (e.g., Zachariasen and Sieh, 1995; Barka et al., 2002). As described above, the scarps within the Mt Chisholm block on the Awatere Fault lie in an en-echelon array, and have a mean spacing of $\sim 175 \mathrm{~m}$ and angles of $<10^{\circ}$ to $20-30^{\circ}$ clockwise from the strikes of the principal fault sections. These observations are similar to those from the Landers and Izmit earthquakes, and suggest the Mt Chisholm scarps may have formed during the transfer of coseismic dextral-oblique slip from one fault section to the other during propagation of the most recent earthquake rupture in 1848 .

Spotila and Sieh (1995) mapped the slip distribution along a $3 \mathrm{~km}$ gap in the dextral-slip surface rupture of the 1992 Landers earthquake in California. The transfer of dextral slip across this gap was accommodated by a zone of thrust fault and en-echelon extensional rupture. The lack of through-going dextral surficial rupture here was interpreted by these authors as a lack of a "mature" fault connection between the principal faults at either end of the gap, yet, despite this, both faults were ruptured during the same earthquake. Spotila and Sieh's (1995) observations imply that two seemingly-unconnected faults will not automatically act as discrete rupture segments. By extension, two faults that are connected across a minor geometrical discontinuity could be reasonably expected to rupture synchronously in the same earthquake, in the absence of any direct evidence to the contrary. Because there is obvious surficial evidence that the Molesworth section scarp coalesces with those of the eastern section, this relationship could be applied to these faults. The geometry of the fault intersection between the eastern and Molesworth sections of the Awatere Fault, and the distribution of scarps within the fault junctions region, therefore suggest the two principal fault sections may rupture simultaneously across the fault junctions region during large magnitude $\left(\mathrm{M}_{\mathrm{w}} \sim 7.5\right)$ earthquakes.

\subsubsection{Southwestern extent of the eastern section}

An important target of this study was to evaluate the southwestern extent, if any, of the eastern section to the southwest of Barefell Pass, perhaps including a junction between the Awatere and Clarence Faults. Establishing the existence or otherwise of such a junction would be important for understanding the distribution of slip between the Awatere Fault and the adjoining Clarence Fault, and for assessing 
the seismic hazard on these structures. In the Guide River catchment, at least 30 spurs with distinct notches were mapped traced from Barefell Pass to near the confluence of the Guide and Acheron Rivers. This lineament is possibly the surface expression of the eastern section of the Awatere Fault at its southwestern extent in the Guide Valley. A caveat for this interpretation is that only one of these notched spurs was obviously dextrally displaced (site 2, Table A.1.), which by itself does not provide definitive evidence that all these notches were formed by the Awatere Fault.

This lineament may also reflect the structural grain of sub-vertical, tightly folded bedding of Torlesse greywacke, which strikes north-northeast across much of northeast South Island (Little and Roberts, 1997). Where outcrops of steeply dipping greywacke beds were observed, however, their strike was generally oblique to the notch-defined lineament. At Barefell Pass, the difference in strike is $20-30^{\circ}$; in the lower Guide Valley, this difference increases to $\sim 40^{\circ}$ as the trend of the spur lineation swings clockwise. As these notches obliquely cross-cut the regional strike of bedrock, their formation is unlikely to be due to differential erosion of the greywacke beds.

The lineament of notched spurs attributable to the southwestern-most extension of the eastern section of the Awatere Fault may be followed at least as far as the Acheron River Valley. At this southwestern limit of the eastern section, uphill-facing notches incised into bedrock spurs were mapped across the hills to the northeast of Acheron River, and downhill (south) facing scarps and ridge rents $\sim 1-2$ $\mathrm{m}$ in height were mapped along a flat-topped ridge $1.5 \mathrm{~km}$ to the west of where the Guide River joins the Acheron (Figure 2.5). It seems most reasonable to infer a late Quaternary tectonic origin for these features, and to extend the Awatere Fault at least as far west as the Acheron River. Kieckhefer (1979) mapped fault scarps and terrace riser displacements of the Clarence Fault in this area. These prominent scarps are mapped to $\sim 500 \mathrm{~m}$ of the ridge rents. The proximity of these two lineaments suggest the Awatere Fault may join with the Clarence Fault in this area, though the Clarence Fault scarps are more sharply defined features than those of the Awatere Fault. This implies that the Clarence Fault may rupture in larger magnitude or higher-frequency earthquakes than those on the Awatere Fault. Alternatively, scarps formed by rupture of the Awatere Fault may merely be obscured beneath the active scree cover that mantles the Rachel Range. The mean strike of the Clarence Fault in the Guide 
River is $050-060^{\circ}$, whereas the lineament of notched spurs that is attributed to the Awatere Fault has a mean trend of $030-040^{\circ}$. If these two strike slip faults do join in the Guide River area, then the intersection between the faults is likely to be $10-30^{\circ}$.

\subsection{CONCLUSIONS}

Detailed mapping and measurement of geomorphic displacements along the Awatere Fault in the upper Awatere and Acheron Valleys provide important new data about the neotectonics of this strike-slip fault near to a fault section junction. The sense of throw, and the ratios of vertical to horizontal slip, for displacements measured on the eastern section do not follow a consistent relationship with the local fault strike, suggesting non-rigid behaviour of the fault blocks with considerable offfault deformation accommodating vertical slip. Horizontal displacement of an impeded stream channel suggests late Quaternary strike-slip on the part of the eastern section southwest of Grey River has accrued at a maximum rate of $8.2 \pm 2.4 \mathrm{~mm} / \mathrm{a}$ since the mid-Holocene. Displacement of an alluvial fan edge in this region has accrued at an average slip rate of $5.6 \pm 1.1 \mathrm{~mm} / \mathrm{a}$ if one assumes a Last Glacial Maximum age for deposition of the fan gravels. This rate is indistinguishable from late Quaternary slip rates calculated at Saxton River on the Molesworth section and at Lake Jasper on the coastal part of the eastern section of the Awatere Fault.

Detailed field mapping of the fault junctions region between the eastern and Molesworth sections refines the previously mapped location of this fault intersection. There is strong geomorphic evidence supporting the extension of the Molesworth section for $\sim 5 \mathrm{~km}$ eastward of the previously mapped termination of this fault section. The new location of the intersection between the Molesworth and eastern sections is approximately $1.2 \mathrm{~km}$ southwest of Kennet River. The fault sections make a low angle, smoothly curved intersection with respect to one another, with an angle of $10-15^{\circ}$ and a fault-orthogonal width of $3 \mathrm{~km}$ from Saxton River southeast through Wards Pass. Comparing the geometry of the junction to results from twodimensional modelling of fault steps and empirical data from modern and historical strike-slip earthquake ruptures suggests this structural feature on the Awatere Fault probably does not constitute a significant impediment to dynamic rupture propagation. The eastern and Molesworth sections of the Awatere Fault may therefore rupture simultaneously during large magnitude earthquakes. The abundant 
scarps throughout the Mt Chisholm block possibly accommodated the transfer of slip between the principal fault sections across the fault junctions region during earthquake rupture propagation.

A conspicuous alignment of notches incised into colluvium-covered bedrock spurs was mapped across steep, scree-covered hillslopes to the southwest of Barefell Pass. This topographic lineament extends southwest from Barefell Pass at a similar elevation and along a similar trend to the trace of the eastern section that was mapped in the region northeast of Barefell Pass. This lineament possibly represents the surface expression of the eastern section in the Guide River catchment, and is traceable to within $\sim 500 \mathrm{~m}$ of the Clarence Fault. The Awatere Fault may therefore join with the Clarence Fault across a narrow fault junctions region $\left(10-30^{\circ}\right)$ near the confluence of the Guide and Acheron Rivers. The different preservation states of the fault scarps in this area suggest the two faults do not rupture with the same frequency, and that the Clarence Fault is probably more active than the Awatere Fault here. 


\section{INFLUENCE OF A FAULT SECTION JUNCTION ON THE RUPTURING BEHAVIOUR OF THE AWATERE FAULT, NEW ZEALAND}

ABSTRACT

The Awatere Fault, one of four principal strike-slip faults within the obliquely-convergent plate boundary zone in northeastern South Island, New Zealand, is comprised of two principal sections (the eastern and Molesworth sections) that diverge across a complex fault junctions region in the upper Awatere Valley. Data from four new paleoseismic trenches excavated on both sides of this junction, including 33 radiocarbon dates, provide the context for investigating the influence of a fault-section junction on the late Quaternary rupturing behaviour of a major strike-slip fault. In addition, these new paleoseismic data significantly refine the seismic hazard posed by these principal strands of the Awatere Fault. On the Molesworth section, $18 \mathrm{~km}$ to the west of the junction, eight well-constrained surface-rupturing events in the past $6.3 \mathrm{ka}$ can be identified, and two, still older events younger than $\sim 15 \mathrm{ka}$ can also be recognised. Taken together, these ten events suggest a mean recurrence interval of $1435 \pm 165$ years on the Molesworth section of the fault, similar to mean recurrence intervals that one can calculate using available data on slip rates and mean per-event displacements. Intervals between individual paleoearthquakes on the Molesworth section are non-uniform, ranging from $<130$ to 1750 \pm 320 cal. years. Interestingly, the frequency of earthquakes on the Molesworth section show a significant increase through the Holocene since $\sim 2.6$ ka B.P., with a much shorter mean recurrence interval of $<570 \pm 90 \mathrm{cal}$. years since this time. On the eastern section, $12 \mathrm{~km}$ to the northeast of the fault junction, five events in the past $5.5 \mathrm{ka}$ have been identified, including a young event ( $<300 \mathrm{cal}$. years B.P.) that is presumed, on the basis of historical data, to be the surface rupture of the $M_{w} \sim 7.5$ 1848 Marlborough earthquake. These events near Upcot Saddle are combined with data from two previous trenches located $\sim 55 \mathrm{~km}$ to the northeast at Lake Jasper, to infer an internally consistent chronology of nine events since 8330-8610 cal. years B.P. on the eastern section. These nine events define a mean recurrence interval of $930 \pm 15$ cal. years on that fault, which is within error of mean recurrence intervals calculated using available data on slip rates and mean coseismic slip during the 1848 earthquake. The intervals between individual paleoearthquakes on the eastern section are nonuniform, as they range from $860-1160$ to $1740-2540$ cal. years. These data do not show any obvious change in the frequency of earthquake occurrence on the eastern section during the Holocene. Wellconstrained overlaps (at $95 \%$ confidence) are presented for the calibrated ${ }^{14} \mathrm{C}$-bracketed ages of five ruptures on both fault sections at 5750-6180, 4250-4600, 3000-3500, 930-1180 and 0-310 cal. years B.P. The prevalence of earthquakes that ruptured both the eastern and Molesworth sections suggest these geomorphically-distinct fault sections have ruptured simultaneously in very large magnitude earthquakes $\left(M_{w}>7.5\right)$, and that the fault junctions region between them does not act as a significant barrier to rupture propagation. Alternatively, the fault sections may rupture sequentially within a short geological time period, possibly as a propagating dynamic rupture on one section triggers failure of the adjacent section. 


\subsection{INTRODUCTION}

Understanding the role of geometric complexities on the earthquake rupturing process is important for seismic hazard assessment as potential earthquake magnitudes are commonly assessed by estimating the maximum length of a future rupture based on the dimensions of previous earthquake ruptures. This requires an assessment of the mechanical role of discontinuities along the fault on the propagation of dynamic earthquake ruptures. Schwartz and Coppersmith (1984) were among the first to advance the idea that discontinuities such as fault bends, stepovers or intersections may compartmentalise active fault systems into discrete earthquake segments that rupture during separate earthquakes, with the discontinuities acting as effective barriers to rupture propagation and/or as preferred sites of rupture nucleation (e.g., King and Nabelek, 1985, Sibson, 1986, Barka and Kadinsky-Cade, 1988). Dynamic propagation of the 1992 Landers earthquake in California and the 1999 Izmit earthquake in Turkey were temporarily impeded by a series of releasing stepovers $1-5 \mathrm{~km}$ wide, but ultimately ruptured across them (Zachariasen and Sieh, 1995; Lettis et al., 2002). Similarly, paleoseismic investigations of the San Andreas Fault suggest large earthquake ruptures can propagate across apparent segment boundaries (e.g., Grant and Sieh, 1994). These observations suggest the predicted size of a future earthquake based on a 'characteristic' fault-segment length may be underestimated (e.g., Rubin, 1996).

The Awatere strike-slip fault within the Marlborough fault system, New Zealand, includes two geometrically distinct active strands that intersect across a complex fault junction region near the Molesworth Station homestead in the upper Awatere Valley (see Figure 3.1). These fault sections, the Molesworth and eastern sections of the fault, can be recognised on the basis of their $20-25^{\circ}$ difference in mean strike and the complexity of surface deformation in the zone across which they intersect. Previous available paleoseismic data, and historical data for the $\mathrm{M}_{\mathrm{w}} \sim 7.5$ 1848 Marlborough earthquake, suggest that the two fault sections may have behaved as independent rupture segments, at least during the 1848 event; however, no detailed studies of paleoseismically defined rupture histories have been conducted across this fault junction. This study addresses this deficit in information, and presents descriptions of the stratigraphy and structure of sediments exposed in four 


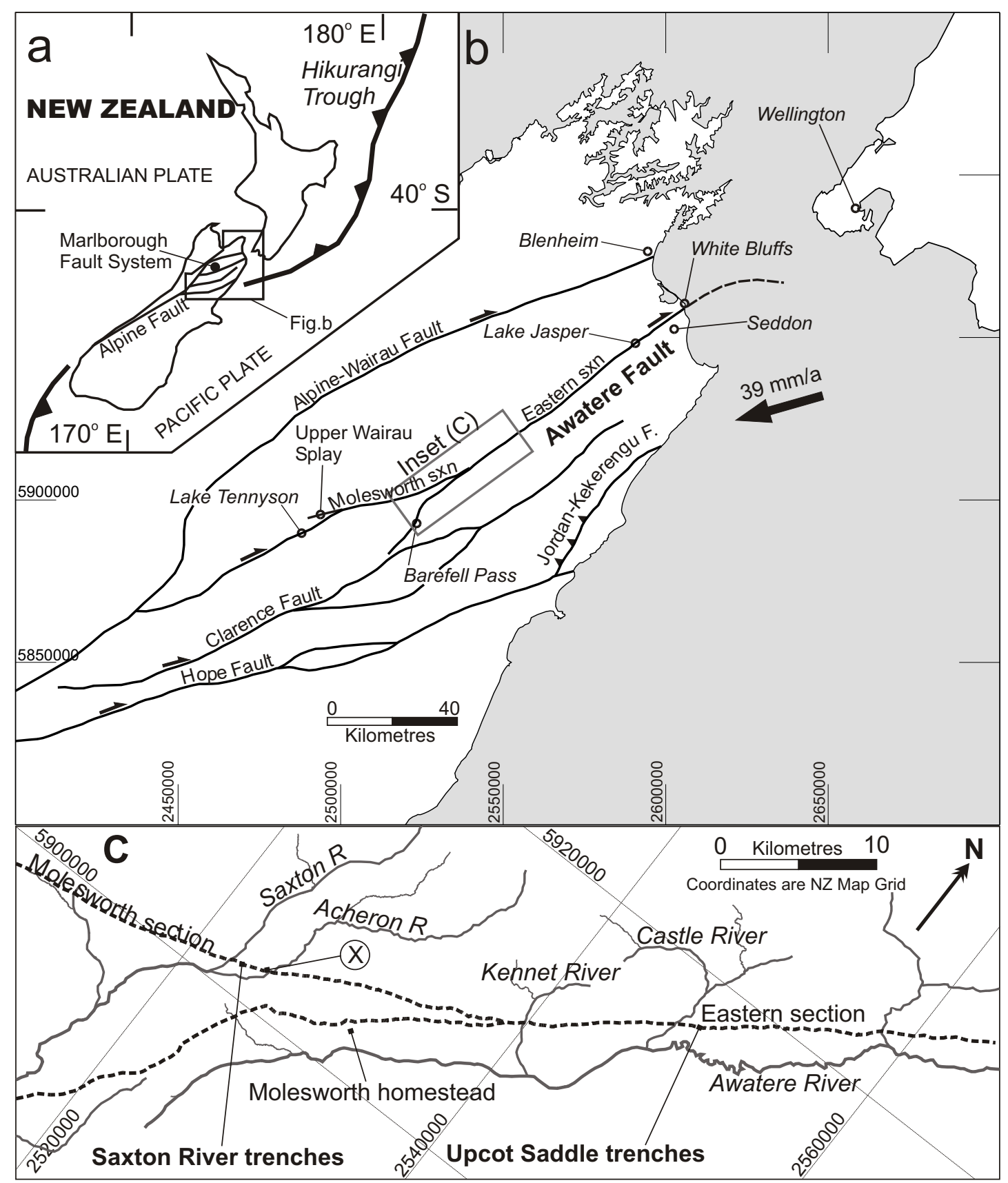

Figure 3.1a-c (A) Map showing Pacific-Australia plate boundary through New Zealand. (B) Map of the Marlborough fault zone (northeast South Island), with principal active faults shown (after Little and Roberts, 1997; Nicol and Van Dissen, 2002). The bold arrow indicates the azimuth and magnitude of Pacific plate motion relative to the Australian plate (De Mets et al., 1990; 1994); the offshore extent of the Awatere Fault is adapted from Carter et al. (1988). (C) Location map of the Awatere Fault trace in the upper Awatere Valley. Point "X" marks the position of a paleoseismic trench excavated by McCalpin (1996a). 
new paleoseismological trenches excavated on either side of this geometric segment junction. The sedimentary and paleoseismic histories from these four trenches were interpreted using the methodology of McCalpin (1996b) for distinguishing evidence for paleoearthquakes from exposures of strike slip faults. Interpretation of crosscutting relationships of these sediments, in combination with 33 new radiocarbon dates, allows the reconstruction of late-Quaternary rupture chronologies for both fault sections in close proximity $(12-18 \mathrm{~km})$ to the junction. These new data are used to (1) refine estimates of the frequency of earthquakes on both sections of the Awatere Fault, and (2) investigate the influence of the fault junction on the seismicity of the Awatere Fault by evaluating which events may have broken across the fault junction. These results have important implications regarding the dynamic rupture behaviour of complex fault-intersection regions on major strike-slip faults.

\subsection{PREVIOUS WORK}

Contemporary observations of an historical rupture of the eastern section of the Awatere Fault suggest that the two geometric fault sections behaved as discrete rupture segments in 1848. Historical accounts prove that the eastern section of the Awatere Fault last ruptured in the $\mathrm{M}_{\mathrm{w}} \sim 7.51848$ Marlborough earthquake, causing extensive shaking, damage to buildings and three deaths in Wellington city (Grapes et al., 1998). Contemporary accounts of landowners, and later surveys by government geologist Alexander McKay, suggest this earthquake involved surface rupture of the eastern section from the east coast at White Bluffs to at least as far west as Barefell Pass. More importantly, the rupture appears to have bypassed the junction with the Molesworth section without triggering rupture there (Grapes et al., 1998).

Before this study, paleoseismic data on the location and timing of surfacerupturing earthquakes on the Awatere Fault was available from detailed trenching studies on the eastern section near the coast at Lake Jasper (Benson et al., 2001, Hill et al., 2001), but was absent for the rest of the eastern section and sparse on the Molesworth section (McCalpin, 1996a). Near Lake Jasper, Benson et al. (2001) and Hill et al. (2001) identified $>7$ surface-rupturing events younger than 8330-8610 cal. years B.P. on the eastern section in two trenches excavated across an $8 \mathrm{~m}$ high fault 
scarp. McCalpin (1996a) mapped the Molesworth section from Acheron River to near Lake Tennyson, and dated the most recent surface rupturing event on that section of the fault by radiocarbon dating and pebble weathering rind calibration to have taken place between 522-597 cal. years B.P. This age is significantly older than the 1848 event on the eastern section, a result that suggested that the 1848 earthquake did not rupture the Molesworth section at all, as is consistent with contemporary historical observations (Grapes et al., 1998). Similarly, the inferred timing of the penultimate event on the Molesworth section (2.5-4.5 ka B.P., McCalpin, 1996a) does not coincide with the paleoseismically determined timing of the penultimate rupture on the eastern section at $\sim 1$ ka B.P. (Benson et al., 2001; Hill et al., 2001). These results imply the eastern section may have ruptured independently from the Molesworth section in the late Quaternary, though the surface rupture record for the Molesworth section may be incomplete, as only 2 ruptures have been identified on the main trace of that section in the past $4.5 \mathrm{ka}$ (McCalpin, 1996a). The goal of this study is to improve the resolution of the surface rupture history of the Molesworth section, and explore the possibility that the two geometric fault sections have behaved as discrete rupture segments.

\subsection{PALEOSEISMOLOGY OF THE MOLESWORTH SECTION AT SAXTON RIVER}

\subsubsection{Saxton River trenches}

On the east bank of Saxton River, a flight of late Quaternary fluvial terraces has been progressively displaced by the Molesworth section of the Awatere Fault. On the highest terrace tread, two laterally adjacent, $\sim 50 \mathrm{~m}$ long transtensional sagponds have developed between right-stepping, bifurcating fault strands (see Figure 3.2). Two trenches were excavated across a $\sim 30 \mathrm{~m}$ wide ephemeral sagpond that has developed between $\sim 1 \mathrm{~m}$ high fault scarps, in order to reconstruct the surface rupture history at this site. The first trench (Saxton-1) was excavated in 2002 at the end of an unseasonably wet summer, causing the water table to be unusually high for the site. For safety reasons, this first trench could only be excavated across the eastern fringe of the sagpond depression, rather than across its depocentre. This trench exposed a thin sequence of massive fine-grained silts underlain by thick, poorly sorted fluvial gravel. Several faults were mapped in this trench, but 


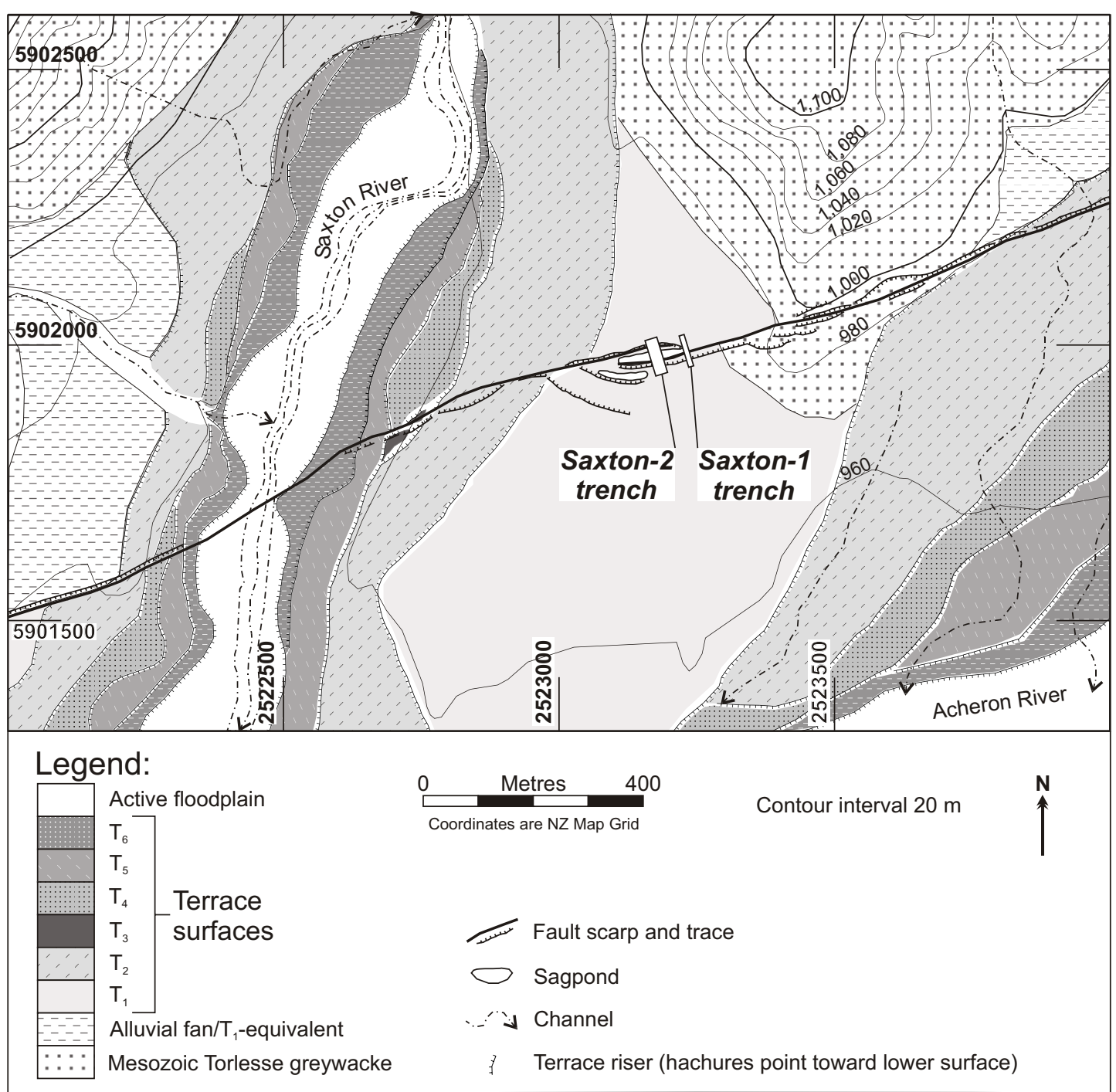

Figure 3.2 Neotectonic map of the Saxton River terraces, showing the location of the paleoseismic trenches excavated across the transtensional depression (sagpond) that has formed between bifurcating fault strands on the highest terrace surface $\left(\mathrm{T}_{1}\right)$. 
individual faulting events could not be differentiated as all these faults were mapped to cut poorly sorted, massive fluvial gravels. The fine-grained, laminated horizons mapped in this trench were unfaulted (Figure 3.3). Later augering proved that the depocentre of the sagpond contains bedded carbonaceous silts and fibrous peats to a thickness of $>1.5 \mathrm{~m}$. For this reason, a second trench (Saxton-2) was excavated across the centre of this fault-bounded depression in 2003 when the groundwater conditions were more favourable. The Saxton-2 trench exposed abundant carbonaceous horizons that revealed clear evidence for multiple faulting events. Because of the poor resolution of data from the Saxton- 1 trench, only the Saxton- 2 trench will be discussed below. The graphical log of the east wall is given in Figure 3.4; whereas an enlargement of the near-surface stratigraphy and fault zones on the east wall is given in Figure 3.5. The log of the west wall is given in Figure 3.6.

$\underline{\text { Stratigraphy and structure of fault strands and sediments exposed in the Saxton-2 }}$ $\underline{\text { trench }}$

The Saxton-2 trench exposed a sequence of massive inorganic silt with intercalated carbonaceous silts, peat layers and paleosols. Detailed lithological descriptions of the stratigraphic units, and the inferred correlatives of individual units across fault zones, are given in Appendix B (Table B.1). Because of the complex fault splaying and the finely laminated nature of the blocks between the fault zones in the upper bench on the east wall (see Figure 3.5), units could not be assumed to correlate or match across the fault strands. For this reason, units were described separately in each major fault block: northern, central and southern. These units are underlain by massive gravels, presumed to be aggradational fan gravels deposited by Saxton River. Individual units from each of these zones are prefaced with "N", "C", "S", and "G", respectively. A brief summary of the stratigraphic units and fault zones is given below.

The units exposed by the Saxton-2 trench are truncated, displaced and thickened across numerous fault strands, that are concentrated into four discrete zones. Fault zone 1 cuts the fine-grained sediments deposited within the sagpond, and consists of a single strand at depth that bifurcates into at least four strands near to the ground surface. Each one of these strands is named separately on the east wall (Figure 3.5) due to the spatial complexity of the rupture history. While upward 


\section{Saxton-1 Trench: East Wall}

\section{$N$}

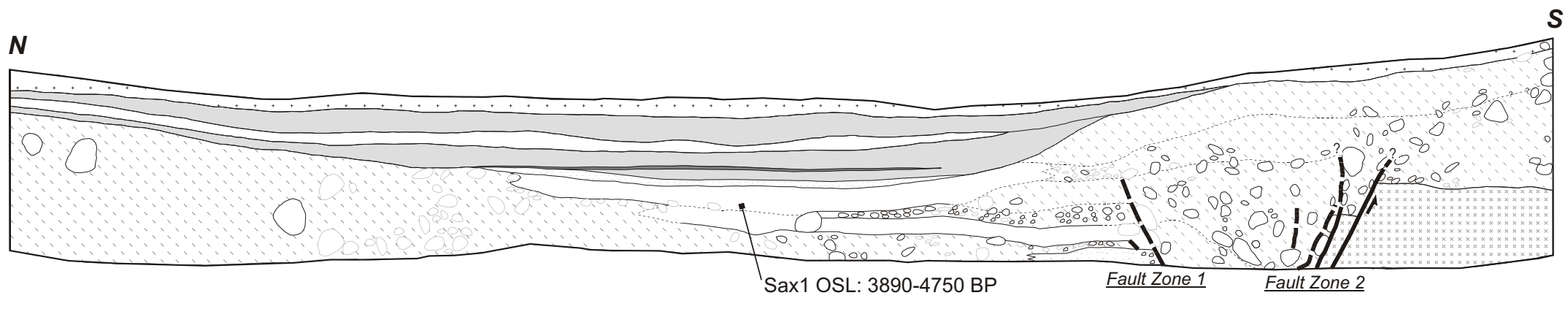

\begin{tabular}{|c|c|c|c|c|}
\hline Inorganic clay/silt & $\because \because \because$ & Gravelly mud & $\infty$ & Individual clast (where differentiated) \\
\hline Organic silt & & Sand/fine gravel & & Indurated sandstone (greywacke) basement \\
\hline
\end{tabular}

Peat/very organic silt

Alluvial fan gravels

Zone of modern soil formation

Contact

Inferred/gradational contact

Fault

- - - Inferred Fault

Figure 3.3 Log of the east wall of the Saxton-1 trench. Because fault zones 1 and 2 did not cut through any fine-grained carbonaceous horizons, the surface rupture history could not be determined from this trench.

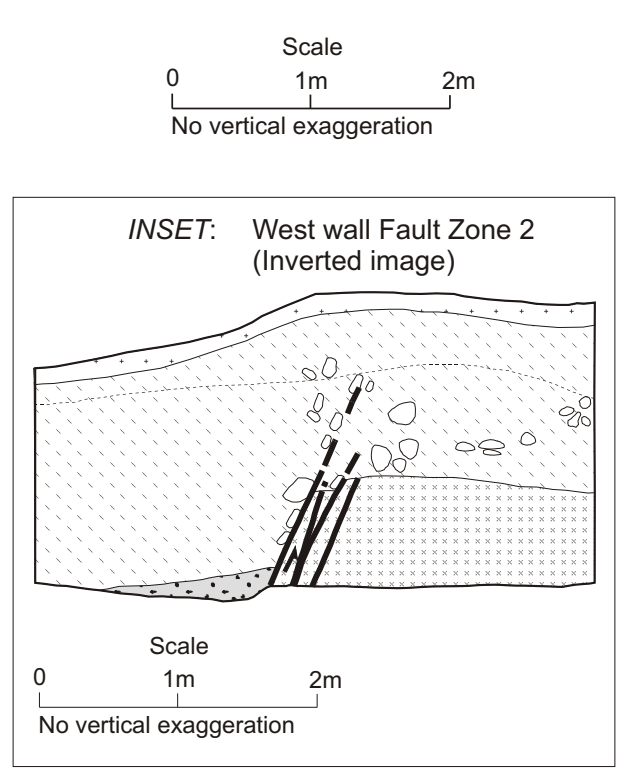




\section{Saxton-2 Trench: East wall}

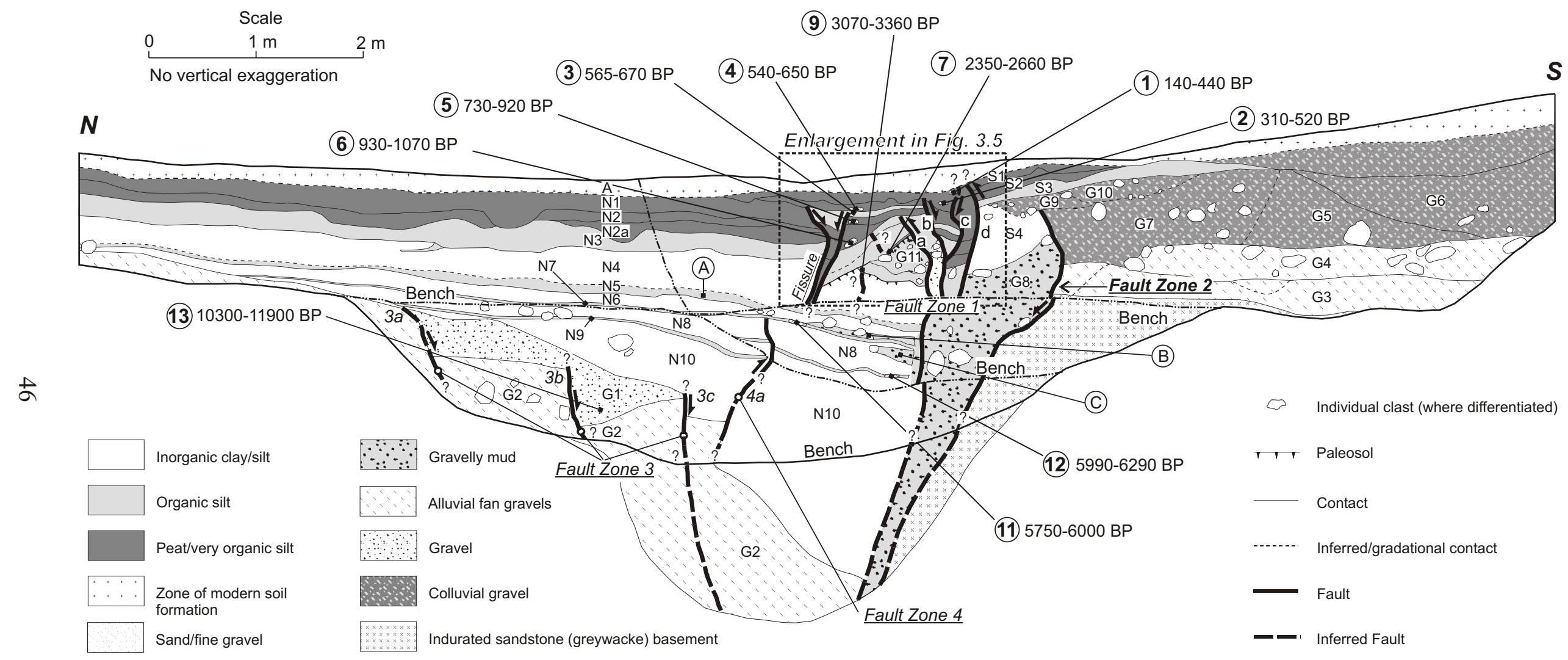

Figure 3.4 Log of the east wall of the Saxton-2 trench, with the position and calibrated ages of optically stimulated luminescence and radiocarbon samples shown (see Table 3.1 for individual sample details). Because of the finely laminated nature of the near-surface stratigraphy between fault zones 1 and 2, the unit labels are shown in the enlargement (Figure 3.5). Locations A, B, and C (circled) identify features mentioned in the text. 


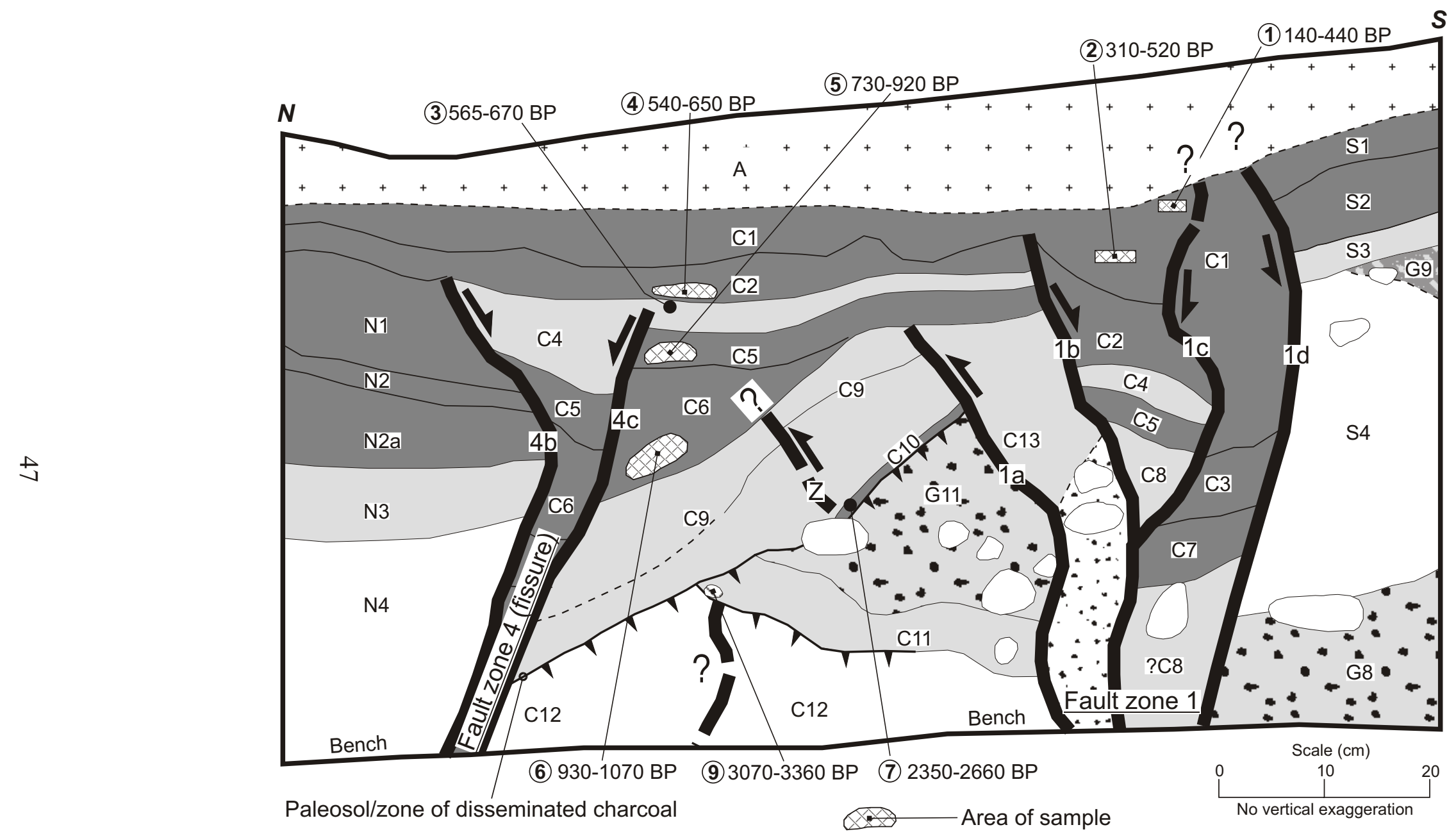

Figure 3.5 Enlargement of the near-surface (upper bench) stratigraphy from the east wall of the Saxton-2 trench. 


\section{Saxton-2 Trench: West wall}

[Inverted image]

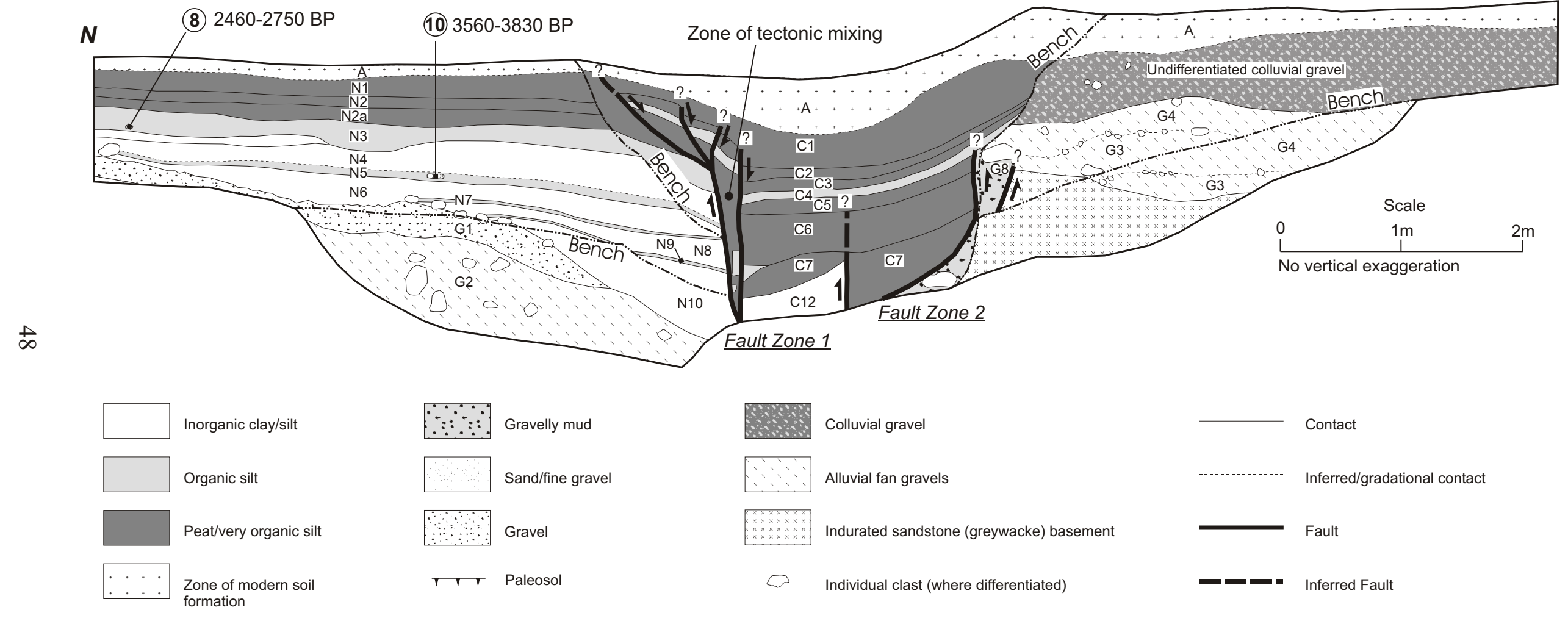

Figure 3.6 Log of the west wall of the Saxton-2 trench, with the position and calibrated ages of radiocarbon samples shown (see Table 3.1 for individual sample details). This log has been inverted to give the same oriented view as the east wall. 
termination of fault strands at different stratigraphic levels does not necessarily require distinct rupture events (e.g., McCalpin, 1996b), on the upper part of the east wall of the Saxton-2 trench such upward terminations are not associated with any obvious fault-tip related stratal rotation or ductile deformation. This suggests that the several fault strands did not terminate as fault tips, but that each strand ruptured to the contemporary ground surface during several discrete events, each of which was followed by mantling of the fault by layers of undeformed sediment. Fault zone 2 consists of one principal strand that juxtaposes indurated sandstones of the Torlesse Supergroup against highly sheared, reworked, sediment. Fault zone 3 consists of three, regularly spaced strands that were mapped near the base of the trench. These strands only displace horizons within the basal gravels underlying the fine-grained sagpond sediments. Fault zone 4 lies between fault zones 2 and 3 and consists of three principal strands; the lowest of these strands displaces the massive silt units near the base of the trench and is possibly a splay off fault zone 3. The remaining two strands of fault zone 4 were two sub-parallel, vertically-discontinuous fault strands mapped on the upper bench of the east wall (the "fissure zone" in Figure 3.4).

Exposed at the base of the Saxton-2 trench are blue-grey unsorted massive gravels (G1, G2). These gravel units are inferred to be correlatives of G3 and G4 on the southern side of the fault zones. Immediately underlying the topographic scarp at the southern end of the trench are a series of colluvial gravels (G5-G7, G9, G10) which are possibly scarp-derived lobes of reworked alluvial gravel. Between fault zones 1 and 2 is a zone of highly mixed, undifferentiated blue-grey silt with vertically-imbricated clasts (G8). Several wedges of poorly sorted silt and gravel (e.g. G11 and other undifferentiated small lobes adjacent to fault zone 1 in Figure 3.4) possibly represent coseismic fault scarp collapse into the sagpond. The base of the Saxton-2 trench on the southern side of fault zone 2 was cut into highly sheared, indurated greywacke sandstone of the Torlesse Terrane, which forms basement in this region (Lensen, 1963; MacKinnon, 1983).

Onlapping and stratigraphically overlying these gravel units are the northern, central and southern units. The northern units consist of medium-dark brown fibrous and laminated silty peats (N1-N2a), light brown and dark blue-grey carbonaceous silt (N3, N5, N7, N9) and blue-grey massive inorganic silt (N4, N6, N8, N10). Four 
radiocarbon ages were obtained from these units (samples 8 and 10-12; see Table 3.1). The central units are separated from the northern units by two sub-parallel fault strands of fault zone 4 (termed the 'fissure zone' in Figure 3.4 and Figure 3.5), and consist of medium-brown fibrous and silty peats (C1-C3, C5-C7), light brown and dark blue-grey carbonaceous silt $(\mathrm{C} 4, \mathrm{C} 8-\mathrm{C} 11, \mathrm{C} 13)$ and blue-grey massive silt (C12). Eight radiocarbon ages provide age control for these units (samples 1-7 and 9; see Table 3.1).

Table 3.1 - Sample descriptions and results of radiocarbon analyses of carbonaceous samples collected from the Saxton-2 trench.

\begin{tabular}{|c|c|c|c|c|c|c|}
\hline $\begin{array}{c}\text { Sample } \\
\text { No. }\end{array}$ & $\begin{array}{c}\text { Laboratory } \\
\text { No.* }^{*}\end{array}$ & Unit & $\begin{array}{l}\text { Material } \\
\text { Dated }\end{array}$ & $\begin{array}{c}\delta^{13} \mathbf{C} \\
(\% \circ \text { wrt PDB) }\end{array}$ & $\begin{array}{c}\text { Conventional } \\
\text { Radiocarbon Age } \\
(\mathrm{yr} B P \pm 1 \sigma)^{1}\end{array}$ & $\begin{array}{c}\text { Calibrated Age } \\
\text { (cal. yr BP; } \\
95 \% \text { confidence) }{ }^{2}\end{array}$ \\
\hline 1 & Wk-13163 & $\mathrm{C} 1$ & peat & $-31.0 \pm 0.2$ & $257 \pm 39$ & $0-460(140-440)$ \\
\hline 2 & Wk-13160 & C1 & peat & $-31.9 \pm 0.2$ & $376 \pm 46$ & $310-510(310-520)$ \\
\hline 3 & Wk-13161 & $\mathrm{C} 4$ & wood & $-29.1 \pm 0.2$ & $624 \pm 44$ & $540-660(565-670)$ \\
\hline 4 & Wk-13159 & C2 & peat & $-30.3 \pm 0.2$ & $674 \pm 44$ & $550-690(540-650)$ \\
\hline 5 & Wk-13157 & C5 & peat & $-30.6 \pm 0.2$ & $898 \pm 36$ & $730-920$ \\
\hline 6 & Wk-13156 & $\mathrm{C} 6$ & peat & $-28.6 \pm 0.2$ & $1095 \pm 33$ & $930-1070$ \\
\hline 7 & NZA 17716 & C10 & $\begin{array}{l}\text { charcoal \& } \\
\text { organic silt }\end{array}$ & -25.1 & $2474 \pm 40$ & $\begin{array}{c}2360-2720 \\
(2350-2660)\end{array}$ \\
\hline 8 & NZA 17807 & N3 & charcoal & -25.0 & $2482 \pm 40$ & $\begin{array}{c}2360-2740 \\
(2460-2750)\end{array}$ \\
\hline 9 & NZA 17806 & C11 & charcoal & -26.6 & $3037 \pm 45$ & $3070-3360$ \\
\hline 10 & Wk-13162 & N5 & organic silt & $-28.5 \pm 0.2$ & $3417 \pm 40$ & $3560-3830$ \\
\hline 11 & NZA 17701 & N7 & organic silt & -27.6 & $5157 \pm 45$ & $\begin{array}{c}5750-6170 \\
(5750-6000) \\
\end{array}$ \\
\hline 12 & $\begin{array}{c}\text { Wk-13158 } \\
\text { (NZA 18165) }\end{array}$ & N9 & $\begin{array}{l}\text { charcoal \& } \\
\text { organic silt }\end{array}$ & $-28.9 \pm 0.2$ & $5390 \pm 52$ & $5990-6290$ \\
\hline 13 & - & G1 & $\begin{array}{c}\text { inorganic } \\
\text { silt }^{3}\end{array}$ & - & - & $11100 \pm 800^{3}$ \\
\hline
\end{tabular}

* Samples with prefix "Wk" denote analyses performed by the Waikato University Radiocarbon Laboratory using Liquid Scintillation Counting; samples with prefix "NZA" denote analyses performed by the Rafter Radiocarbon Laboratory at the Institute of Geological and Nuclear Sciences using Accelerator Mass Spectrometry.

${ }^{1}$ Result based on Libby half-life of 5568 yr with correction for isotopic fractionation applied

${ }^{2}$ Radiocarbon ages were calibrated to calendric years before 1950 using OxCal v3.9 software of Ramsey (1995; 2003), incorporating atmospheric data from Stuiver et al. (1998). The age ranges shown in parentheses are posterior age distributions calibrated according to the stratigraphic order of the samples (see Figure 3.7).

${ }^{3}$ This sample was dated by optically stimulated luminescence (OSL) dating at the Luminescence Laboratory of the Victoria University of Wellington, and is a preliminary OSL age

The southern units are separated from the central units by fault zone 1 . These consist of dark brown fibrous peat and brown-grey carbonaceous silt (S1-S3) and 
blue-grey massive silt (S4). Overlying all three of these blocks is dark brown fibrous peat with abundant modern roots (unit A) that is inferred to be the A horizon of the modern soil.

\section{Paleoseismic record preserved in the Saxton-2 trench}

Interpretation of the logged cross-cutting and tilting relationships between horizons exposed in the Saxton-2 trench allows the differentiation of up to ten paleoearthquakes. Slumping of the peat-rich part of the west wall between fault zones 1 and 2 made logging this section in detail difficult, and therefore the bulk of the paleoseismic interpretation was derived from logging of stratigraphic relations on the more stable east wall. In this study maximum and preferred age ranges for each event are presented (e.g., Benson et al., 2001). Because a calibrated radiocarbon age is typically an asymmetric or bimodal probability distribution function for that sample forming in any given calendar year (Biasi et al., 2002), the calibrated ${ }^{14} \mathrm{C}$ data are quoted as a total age range (i.e. $\mathrm{t}_{0}-\mathrm{t}_{2}$ ) at the $95 \%$ confidence limit, rather than a mean and standard deviation (i.e. $\mathrm{t}_{1} \pm \sigma_{1}$ ). Thus the maximum and preferred ages for paleoearthquakes are also quoted as total age ranges. The maximum permissible age ranges are provided by the calibrated ages of radiocarbon samples that postdate and predate the inferred event. Preferred age ranges represent the most probable time of faulting as evaluated on the basis of the stratigraphic context by extrapolation of event horizon ages between dated samples on the assumption of uniform sedimentation rates.

The assumed maximum age of the fine-grained sediments in the sagpond depression is $14.5 \pm 1.5 \mathrm{ka}$, provided by an optically stimulated luminescence (OSL) age of silt on top of the terrace surface (Chapter 5) that is assumed to be correlative to the silts in the sagpond depression. This OSL age provides a maximum age for all ten of the earthquakes recognised in the trench; an OSL age of $11.1 \pm 0.8 \mathrm{ka}$ from gravel unit G1 provides age control for oldest two events. A suite of 12 radiocarbon samples from the stratigraphically-overlying silt and peat sequence provides narrow age ranges on the youngest eight surface rupturing events (see Table 3.2). Many of the radiocarbon samples were from vertically adjacent horizons, and as a result some have overlapping calibrated age distributions. These overlapping ages have been recalibrated using the OxCal v3.9 software of Ramsey $(1995 ; 2003)$ to incorporate 


\begin{tabular}{|c|c|c|}
\hline 1: 0-460 (140-440) & & $M A$ \\
\hline 2: $310-510(310-520)$ & & $M$ \\
\hline 4: 550-690 (540-650) & & $M$ \\
\hline 3: 540-660 (565-670) & & $M$ \\
\hline 5: $730-920$ & & Min \\
\hline 6: 930-1070 & & $M$ \\
\hline $7: 2360-2720(2350-2660)$ & mivm & \\
\hline 8: $2360-2740$ (2460-2750) & mann & \\
\hline 9: $3070-3360$ & $M^{M} W_{W L}$ & \\
\hline 10: $3560-3830$ & $w^{N} m_{L}$ & \\
\hline 11: $5750-6170(5750-6000)$ & Mm & \\
\hline 12: $5990-6290$ & MWM & \\
\hline Calibrated age ranges & Calibrated age (years B.P.) & 2000 \\
\hline
\end{tabular}

Figure 3.7 Plot of radiocarbon samples from the Saxton-2 trench showing prior age calibrations (dashed lines with greyscale fill) and posterior age distributions (solid lines with white fill). Both age distributions are quoted for each sample at the $95 \%$ confidence limit; the posterior distributions are given in parentheses. This figure shows how the probability distributions of the calibrated ages can be weighted according to the stratigraphic order of the samples (e.g., Biasi and Weldon, 1994; Biasi et al., 2002). This method weights the probability that a given sample formed in any given calendar year according to the proximity of mutually exclusive super/subjacent samples; samples 3, 4, 7 and 8 are notable examples of how this method can alter the calibrated age of a sample. Age calibrations and posterior age distributions were calculated using the OxCal v3.9 software of Ramsey $(1995 ; 2003)$. 
A narrower age range for this event could be assigned on the basis of the calibrated age of sample 2 (310-520 cal. years B.P.). This sample lies beneath the apparent terminations of the Event 1 fault strands, suggesting this event considerably postdates deposition of this sample. This would yield a speculative preferred age of 0-310 cal. years B.P. for Event 1.

Stratigraphic evidence for Event 2 was observed on the east wall, where an organic silt layer $(\mathrm{C} 4)$, truncated by fault zone strand $1 \mathrm{~b}$, is overlain by a peat unit (C1) that is unfaulted by this fault strand. This event ruptured fault zone $1 \mathrm{~b}$, displacing $\mathrm{C} 4$ and possibly tilting/draping the overlying peat unit $(\mathrm{C} 2)$ above the upward termination of the fault strand. These units were later mantled by deposition of $\mathrm{C} 1$. Event 2 is therefore older than deposition of $\mathrm{C} 1$ at $310-520$ cal. years B.P. (sample 2) and younger than deposition of $\mathrm{C} 4$ at 565-670 cal. years B.P. (sample 3). As C2 thickens on the downthrown side of fault zone 1b, and is also possibly offset, Event 2 was possibly synchronous with deposition of this unit at 540-650 cal. years B.P. (sample 4). Accordingly, the calibrated age of this inferred event horizon is used as the preferred age for this event.

The upward truncation of two, sub-parallel fault zone 4 strands beneath the lobate organic silt $\mathrm{C} 4$ is used to infer Event 3. These faults ( $4 \mathrm{~b}$ and $4 \mathrm{c})$ are deemed to represent a discontinuous fault zone created by coseismic fissuring of the ground surface, based on their limited vertical extent and the lack of an equivalent structure on the opposite trench wall. Where other fault zones seen in the east wall have correlatives in the west wall, this 'fissure zone' (fault zone 4) projects toward a zone of undeformed silts and peats on the west wall. Event 3 created a surface depression between the two fissure zone strands (possibly during rupture of a principal fault strand such as fault zone 2) which was subsequently filled by $\mathrm{C} 4$ silt. This event therefore occurred before deposition of $\mathrm{C} 2$, which is undeformed by the fissure zone faults and does not thicken across them, at 540-650 cal. years B.P. (sample 4). Event 3 must have occurred after deposition of the faulted unit C5 at 730-920 cal. years B.P. (sample 5). The geometry of unit $\mathrm{C} 4$ suggests that it infilled the tectonic depression between the walls of the fissure immediately following Event 3 . Assuming that $\mathrm{C} 4$ was deposited essentially syntectonically with this rupture, the 
calibrated age of sample 3 (565-670 cal. years B.P., sample 3$)$ is used as the preferred age of Event 3.

The chief stratigraphic evidence for Event 4 is a prominent angular discordance between a tilted organic silt/paleosol (units C9 and C10) and a younger, relatively untilted peat (C5) on the south side of the fissure zone on the east wall (Figure 3.5). This event involved northward tilting (and possibly displacement) of units $\mathrm{C} 9$ and $\mathrm{C} 10$ across fault zone 1a, followed by deposition of the wedge-shaped peat (C6) above these units in the accommodation space created by this event. This is supported by the upward termination of a small splay, Z, beneath the base of C6 (Figure 3.5). In tilting $\mathrm{C} 9$ and $\mathrm{C} 10$ to the north, this event possibly reversed some of the southward tilting of the underlying paleosol (unit C11) that occurred during Event 5 (see below). Still later, the peat sequence and fault zone 1a were mantled by deposition of $\mathrm{C} 5$ and C6. Event 4 therefore occurred before deposition of C5 at 730920 cal. years B.P. (sample 5) and after deposition of C10 at 2350-2660 cal. years B.P. (sample 7). The preferred age range is 930-1070 cal. years B.P., provided by the age of deposition of the inferred event horizon C6 (sample 6) and based on the presumption this peat was deposited immediately after this event.

Stratigraphic evidence for Event 5 is an angular discordance between the paleosol/organic silt sequence (C9 and C10) and an older paleosol and organic silt couplet (unit C11). This event involved southward tilting and truncation of C11 by fault zone 1a, with possible coseismic deposition of a scarp-derived gravel wedge (G11) on top of C11, and was followed by the unconformable deposition of units C9 and C10. Event 5 occurred before deposition of $\mathrm{C} 10$ at 2350-2660 cal. years B.P. (sample 7), was possibly synchronous with deposition of G11, and occurred after deposition of $\mathrm{C} 11$ at 3070-3360 cal. years B.P. (sample 9). Assuming a constant sedimentation rate for C11 (silt), and near-instantaneous deposition of G11 (gravel), allows a preferred age to be estimated for this event. In the undeformed sequence to the north of fault zone 1 on the west wall, unit N4 (presumed to be the lateral equivalent of unit $\mathrm{C} 11$ based on their similar radiocarbon ages) accumulated at a rate of $\sim 18-30 \mathrm{~cm} / \mathrm{ka}$, using the sediment thickness between samples 8 and 10 (Figure 3.6). If the base of G11 on the east wall represents the event horizon for Event 5, then the thickness of $\mathrm{C} 11(\sim 20 \mathrm{~cm})$ represents the amount of time that elapsed following deposition of the charcoal at its base (sample 9) before Event 5. These 
accumulation rates suggest Event 5 occurred $\sim 300-600$ years after deposition of sample 9, which yields a preferred age range of $\sim 2500-3000$ cal. years B.P.

An angular discordance of $\sim 5-10^{\circ}$ between organic silts N3 and N5 provides evidence for Event 6. This angular discordance is the relative angle N5 makes to N3 at an inflection point (point "A" on Figure 3.4) where the dip of N5 steepens. The discordance is visible on both walls, but the fault strands that may have ruptured the surface during this event cannot be identified due to the tectonically mixed nature of the sediment between fault zones 1 and 2 (unit G8). Event 6 appears to have involved deepening of the basin, and consequent southward tilting of unit N5, due to normal offset across the principal strands of fault zones 1 or $2.20-40 \mathrm{~cm}$ of vertical slip across these fault zones during Event 6 is implied by $5-10^{\circ}$ of discordance between units $\mathrm{N} 3$ and $\mathrm{N} 5$ at a distance of 2-3 $\mathrm{m}$ from the faults. This calculation possibly overestimates the amount of slip during this event, as the silt that lies between N3 and N5 (unit N4) only appears to thicken by 10-15 cm. This event occurred before deposition of N3 at 2460-2750 cal. years B.P. (sample 8) and after deposition of N5 at 3560-3830 cal. years B.P. (sample 10). To the north of point A, the thickness of unit N4, and therefore the angle between N5 and N3, remains relatively constant. The amount of thickening of $\mathrm{N} 4(10-15 \mathrm{~cm})$ can be used as a proxy for the elapsed time between deposition of N5 and deformation during Event 6. Using sedimentation rates of $\sim 18-30 \mathrm{~cm} / \mathrm{ka}$ between units $\mathrm{N} 3$ and $\mathrm{N} 5$ (samples 8 and 10), 10-15 cm of thickening of N4 represents a preferred age range of $\sim 3000$ 3500 cal. years B.P. for Event 6 (i.e. 300-800 years after deposition of N5).

A subtle angular discordance of $5-6^{\circ}$ between organic silt units N5 and N7 provides evidence for Event 7. This discordance is more obvious on the west wall than on the east. In addition, a small wedge of poorly sorted silt and gravel at the base of N6, adjacent to fault zone 1 on the east wall, is possibly a scarp-derived lobe of gravel deposited during this earthquake (point "B" on Figure 3.4). The presence of this gravel suggests Event 7 ruptured fault zone $1( \pm 2)$, deepening the basin and tilting N7 to the south. This event therefore occurred before deposition of N5 at 3560-3830 cal. years B.P. (sample 10) and after deposition of N7 at 5750-6000 cal. years B.P. (sample 11). If deposition of the lobe of gravel was coseismic with Event 7 , then the stratigraphic position of this gravel suggests this event occurred not long after deposition of N7 (see Figure 3.4). To the north of point B, the thickness of N6 
is constant at 10-12 cm, suggesting this amount of sediment had accumulated prior to tilting during Event 7. As sedimentation of $\mathrm{N} 6$ occurred at $8-10 \mathrm{~cm} / \mathrm{ka}$ (calculated between samples 10 and 11), then this 10-12 cm accumulation of N6 represents 1000-1500 years between deposition of unit N7 and rupture during Event 7, and the maximum preferred age range for this event would be 4250-5000 cal. years B.P.

The upward truncation of fault zone 4a beneath N7 on the east wall, an angular discordance of $<10^{\circ}$ between N9 and N7, and the presence of a small wedge of gravel adjacent to fault zone 1 (point " $\mathrm{C}$ " on Figure 3.4) are used as evidence for an earthquake that took place between deposition of N9 and N7 (Event 8). This event predates deposition of N7 at 5750-6000 cal. years B.P. (sample 11) and postdates deposition of N9 at 5990-6290 cal. years B.P. (sample 12). Similar to Event 7, the small gravel wedge near the top of $\mathrm{N} 8$ is inferred to have been coseismically deposited during this event, and suggests Event 8 occurred closer in time to deposition of N7. The small difference in calibrated age between samples 11 and 12 mitigates any meaningful estimation of sedimentation rates, and therefore the calibrated age of sample 11 is used as the preferred age for Event 8.

Evidence for two older events (Events 9 and 10) were observed in inorganic sediments exposed near the base of the east wall, but their age could not be resolved by radiocarbon dating. Displacement of the top contact of G1 by strands of fault zones 3 and 4 provides stratigraphic evidence for Event 9. This is inferred to be distinct from Event 10, which ruptured fault zone 3 strands $\mathrm{a}$ and $\mathrm{b}$ and displaced the top contact of G2, creating a tectonic depression that was infilled by fluvial gravel unit G1. The age of G1 is provided by an optically stimulated luminescence age of $11.1 \pm 0.8$ ka B.P. (sample 13; Figure 3.4), which provides a maximum age for Event 9 and a minimum age for Event 10. Event 9 predates deposition of N9 at 5990-6290 (sample 12) and postdates deposition of G1 at 10300-11900 years B.P. (sample 13). Event 10 predates deposition of G1 at 10300-11900 years B.P. (sample 13), and postdates deposition of G2, which was undated. An inferred maximum age for G2 is provided by an OSL age of 13000-16000 years B.P. from silt on top of the alluvial terrace surface (Chapter 5). Unconformities between gravels at the base of the trench (G1 and G2) and the overlying silts prevent any meaningful estimation of sedimentation rates for deposition of $\mathrm{G} 1$, and therefore preferred ages cannot be estimated for Events 9 and 10. These two events possibly date from the early 
development of the sagpond depression, as they involve displacement of the terraceforming alluvial fan gravels and occurred before deposition of the fine-grained sagpond sediments.

\subsubsection{Integrated paleoseismic history for the Molesworth section}

The new results from Saxton River significantly revise and enlarge the paleoseismic history of the Molesworth section initiated by McCalpin (1996a). The bracketing and preferred age ranges of surface rupturing events at Saxton River, together with the previous data of McCalpin (1996a), are presented in Figure 3.8 and in Table 3.2 .

On the basis of four paleoseismic trenches (including one trench excavated between Saxton and Acheron Rivers; see Figure 3.1), hand-dug trenches and stream cut exposures, McCalpin (1996a) inferred four earthquakes on the Molesworth

section from Acheron River to Lake Tennyson. These were dated by $33{ }^{14} \mathrm{C}$ ages to have taken place at 522-597, 751-873, 1296-2923 and 2500-4500 cal. years B.P. The youngest of these correlates well to Event 2 in the Saxton-2 trench. If it is correlative, then Event 2 from the Saxton-2 trench would be further constrained by McCalpin's data to be no older than $\sim 600$ cal. years B.P. McCalpin's penultimate event at 751-873 cal. years B.P. ruptured the $9.5 \mathrm{~km}$ long upper Wairau splay (Figure 3.1), but as this age range overlaps with the timing of both Events 3 and 4 at Saxton River, this event does not help to refine the ages of either event at Saxton River. This event may not have ruptured the entire Molesworth section, as a bend in the fault near Lake Tennyson may have acted as a barrier to earthquake rupture propagation, separating the upper Wairau splay into a discrete rupture segment independent from the more eastern reach of the Molesworth section between Lake Tennyson and Kennet River (McCalpin, 1996a). McCalpin's event at 1296-2923 cal. years B.P. was also identified from exposures along the upper Wairau splay, but because of its broad age range it cannot be robustly correlated to any of the events at Saxton River. McCalpin's oldest event at 2500-4500 cal. years B.P. is indistinguishable from Events 5, 6 and 7 from the Saxton-2 trench, and because of its broad age range it does not help to refine the age ranges of any of the events identified at Saxton River. 
Calender years B.P.

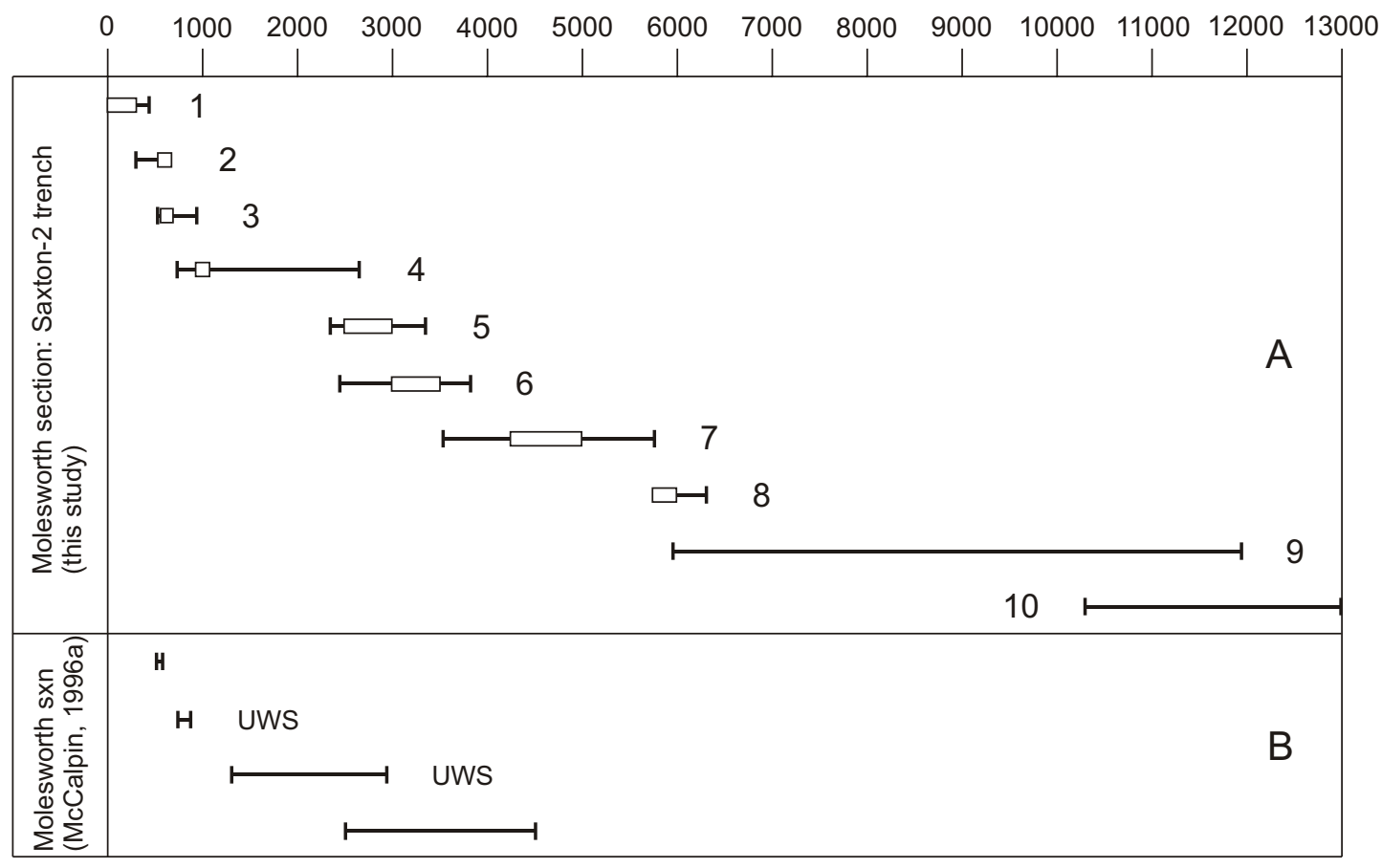

Figure 3.8a-b Earthquake chronologies for the Molesworth section of the Awatere fault. The boxes indicate the most probable time of faulting (the 'preferred age') as interpreted from stratigraphic evidence, and the bracketing limits represent the maximum permissible limits for faulting events as determined from ${ }^{14} \mathrm{C}$ and optically stimulated luminescence dating. (A) Chronology of late Quaternary surfacerupturing paleoearthquakes on the Molesworth section at Saxton River. (B) Chronology of surface rupturing paleoearthquakes inferred along the length of the Molesworth section from Acheron River to Lake Tennyson; UWS = events that ruptured the upper Wairau Splay (McCalpin, 1996a). 


\subsection{PALEOSEISMOLOGY OF THE EASTERN SECTION IN THE UPPER AWATERE VALLEY}

\subsubsection{Upcot-1 trench}

To reconstruct the surface rupture history of the eastern section, a paleoseismic trench was excavated at a site $\sim 12 \mathrm{~km}$ northeast of the fault junction, between Castle River and Upcot Saddle (Figure 3.9). At this site dextral displacement of a bedrock ridge has deflected a small stream, impeding drainage across the fault and resulting in deposition of swamp and fluvial sediments against the $<10 \mathrm{~m}$ high shutter ridge scarp. The $25-30 \mathrm{~m}$ long Upcot- 1 trench was excavated in 2002 across the flat-lying swamp and the lowest 3-5 $\mathrm{m}$ of the adjacent fault scarp. This trench was 4-5 m deep, but did not reach the base of the swamp deposits as time constraints and groundwater flow made deepening the trench impractical. The graphical $\log$ of the northeast wall of Upcot-1 is given in Figure 3.10 and the southwest wall in Figure 3.11.

$\underline{\text { Stratigraphy and structure of fault strands and sediments exposed in the Upcot-1 }}$ trench

The Upcot-1 trench exposed fluvial gravels and silts, ponded silts and peats, and scarp-derived colluvial fans and debris-flow deposits (Figure 3.10, Figure 3.11). These sequences are cut by two fault zones. Fault zone 1 cuts through the centre of the trench to the northwest of the topographic scarp, whereas fault zone 2 cuts colluvial fans beneath the scarp's slope break. The units exposed in the trench are described in two fault blocks (northern and southern) that are separated by fault zone 1. A synopsis of the logged fault zones and stratigraphic units is given below (see Appendix B, Table B.2, for detailed unit descriptions).

The principal strand of fault zone 1 truncates the lower northern units; the upper northern units are anticlinally deformed above the upward termination of several bifurcating splays of fault zone 1. The principal strand of fault zone 1 has a shallow to moderate southeast dip, despite the generally steep northwest dip of the Awatere Fault on a regional scale (e.g., Little et al., 1998). Fault zone 1 is likely to be a contractional, oblique-reverse splay off the more steeply dipping 'master' fault at depth that has developed as an antithetic structure on a small, right-stepping bend 


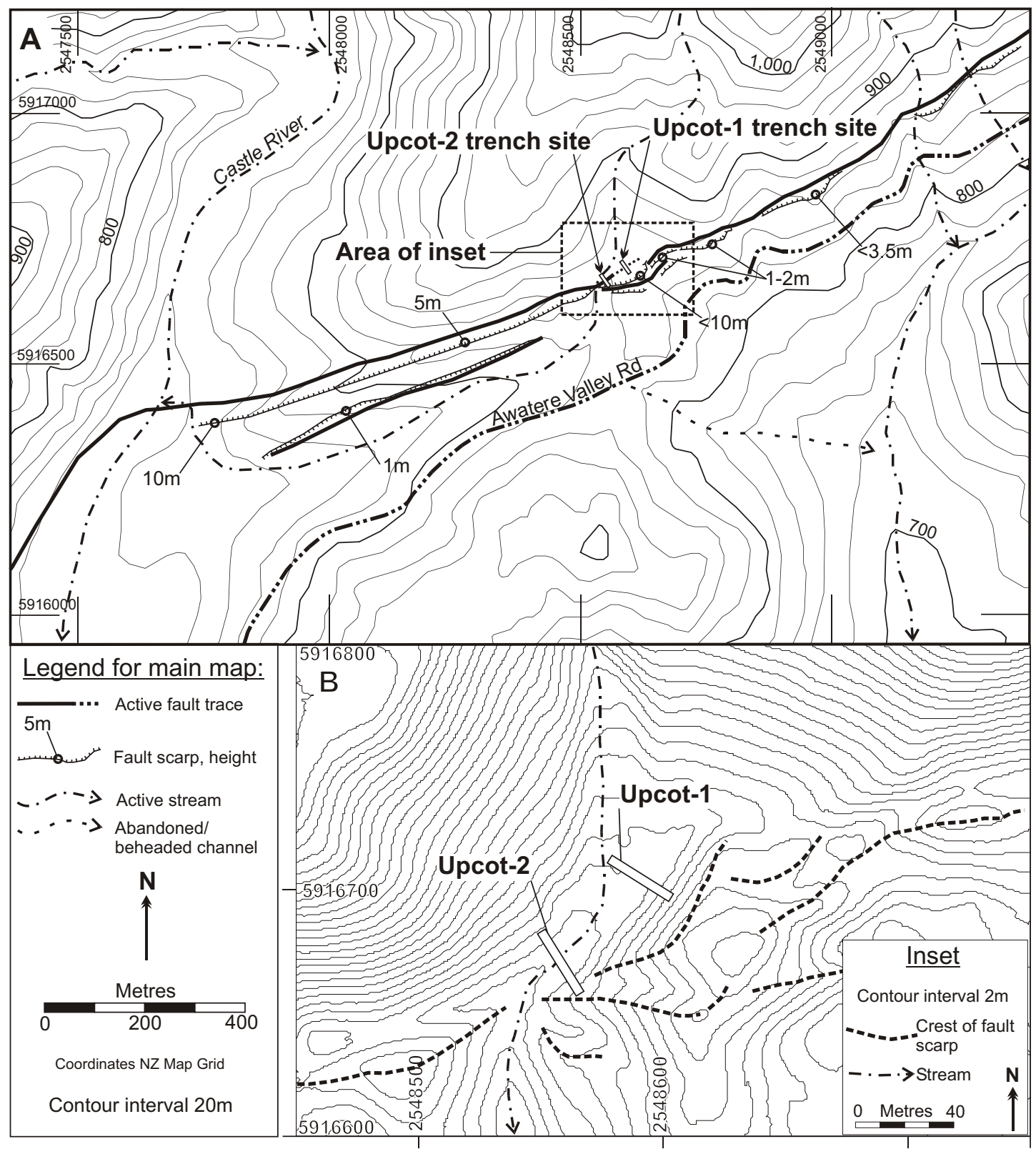

Figure 3.9a-b (A) Neotectonic map of the Upcot Saddle trench site showing the location of the paleoseismic trenches excavated across the $<10 \mathrm{~m}$ high fault scarp (shutter ridge) through the swamp of a fault-deflected tributary of Castle River. (B) Contour map of the shutter ridge and deflected channel surveyed with an RTK-GPS, with the position of the two trenches shown. The complex zone of fault scarps through the shutter ridge has also been accentuated. 
Upcot-1 Trench: Northeast wall

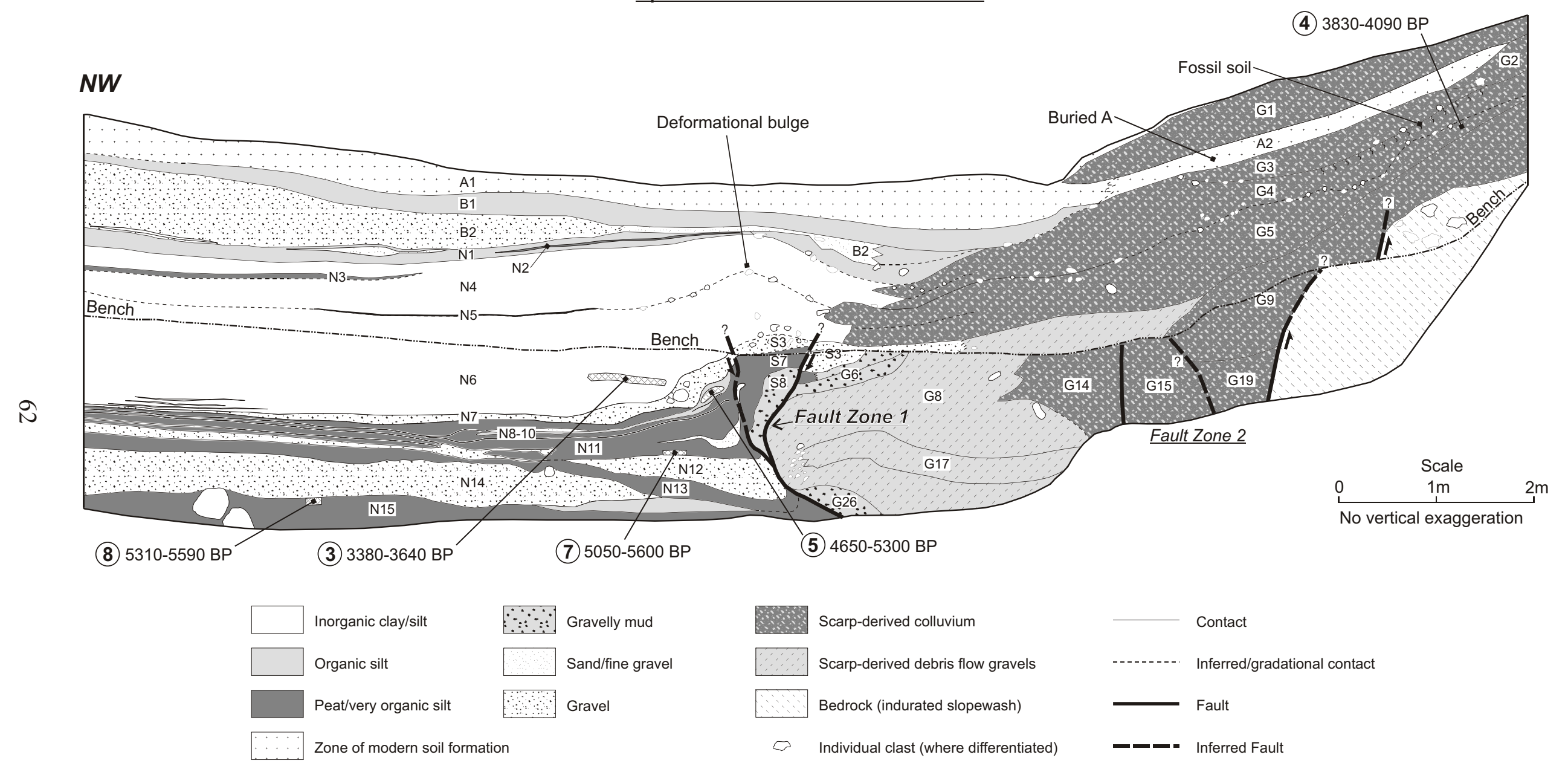

Figure 3.10 Log of the northeast wall of the Upcot-1 trench, with the position and calibrated ages of radiocarbon samples shown (see Table 3.3 for individual sample details). 


\section{Upcot-1 Trench: Southwest wall}

(Inverted image)

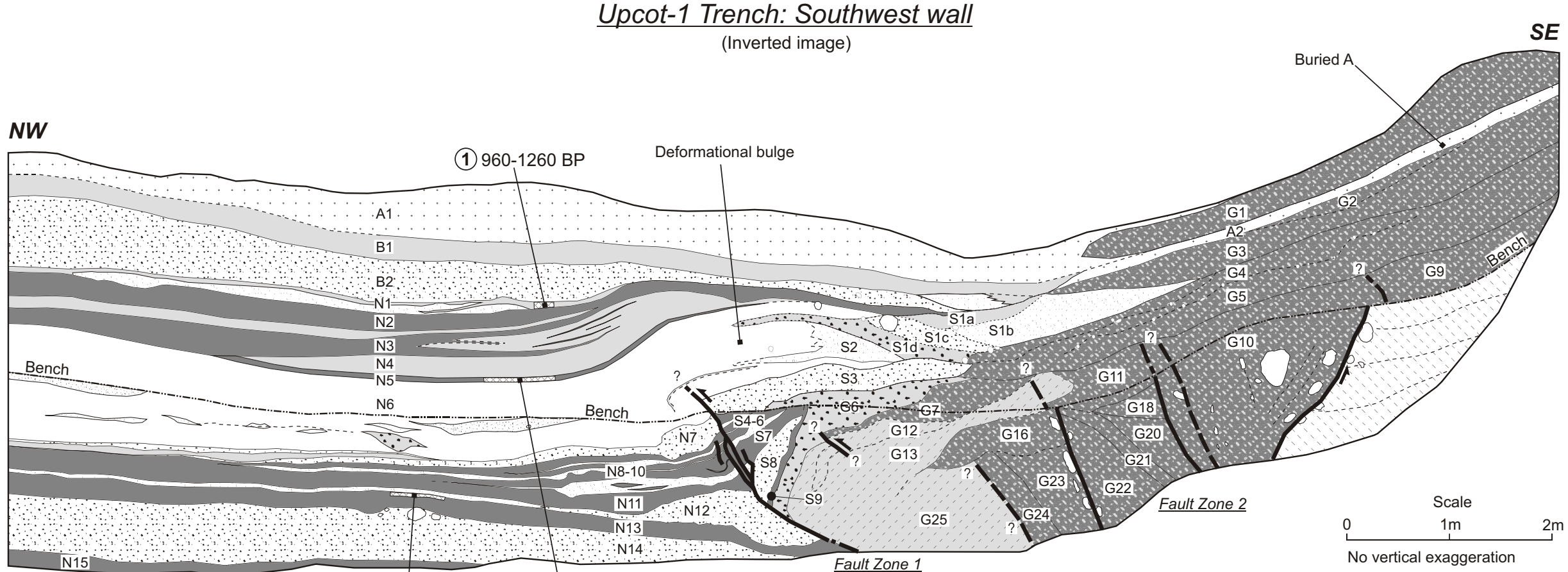

(6) $4960-5310 \mathrm{BP}$ (2) $1600-1890 \mathrm{BP}$

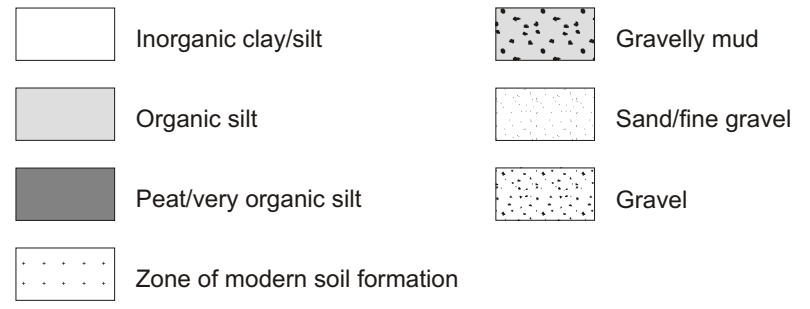

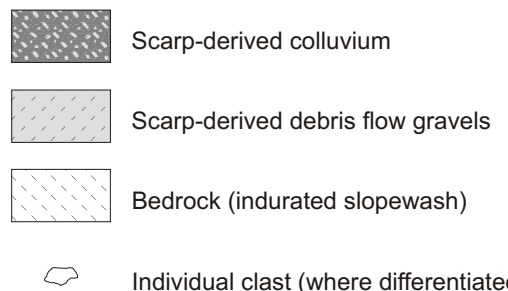

Contact

Inferred/gradational contact

Fault

Figure 3.11 Log of the southwest wall of the Upcot-1 trench, with the position and calibrated ages of radiocarbon samples shown (see Table 3.3 for individual sample details). This $\log$ has been inverted to give the same oriented view as the northeast wall. 
on this part of the Awatere Fault. While the northern units appear to correlate across fault zone 1, thickness and lithology contrasts across these oblique-slip faults makes such stratigraphic correlations difficult. The northern units consist of brown-grey carbonaceous silts $(\mathrm{N} 1, \mathrm{~N} 4)$, light brown silty peats to dark brown fibrous peats (N2, N3, N5, N11, N13, N15), blue-grey massive silt (N6), blue-grey poorly sorted massive gravels (N7, N12, N14) and several thin blue-grey, poorly sorted fine sand and sandy gravel layers that are intercalated with finely laminated peats (N8-N10). Seven radiocarbon ages were obtained from these units (samples 1-3, 5-8; see Table $3.3)$.

Table 3.3 - Sample descriptions and results of radiocarbon analyses of carbonaceous samples collected from the Upcot-1 trench.

\begin{tabular}{|c|c|c|c|c|c|c|}
\hline $\begin{array}{c}\text { Sample } \\
\text { No. }\end{array}$ & $\begin{array}{c}\text { Laboratory } \\
\text { No.* }\end{array}$ & Unit & $\begin{array}{c}\text { Material } \\
\text { Dated }\end{array}$ & $\begin{array}{c}\delta^{13} \mathbf{C} \\
(\% \circ \text { wrt PDB) }\end{array}$ & $\begin{array}{c}\text { Conventional } \\
\text { Radiocarbon Age } \\
(\mathrm{yr} \mathrm{BP} \pm 1 \sigma)^{1}\end{array}$ & $\begin{array}{c}\text { Calibrated Age } \\
\text { (cal. yr BP; } \\
95 \% \text { confidence) }{ }^{2}\end{array}$ \\
\hline 1 & Wk-11059 & $\mathrm{N} 1$ & organic silt & $-27.9 \pm 0.2$ & $1183 \pm 56$ & $960-1260$ \\
\hline 2 & Wk-11058 & N5 & peat & $-31.1 \pm 0.2$ & $1823 \pm 58$ & $1600-1890$ \\
\hline 3 & Wk-11816 & N6 & organic silt & $-29.9 \pm 0.2$ & $3276 \pm 55$ & $3380-3640$ \\
\hline 4 & NZA 17112 & G5 & charcoal & -24.1 & $3651 \pm 45$ & $3830-4090$ \\
\hline 5 & WK-11057 & N8 & peat & $-30.8 \pm 0.2$ & $4351 \pm 108$ & $\begin{array}{c}4600-5350 \\
(4650-5300)\end{array}$ \\
\hline 6 & Wk-11060 & N13 & peat & $-29.2 \pm 0.2$ & $4460 \pm 55$ & $\begin{array}{c}4870-5300 \\
(4960-5310)\end{array}$ \\
\hline 7 & Wk-11815 & N11 & peat & $-29.4 \pm 0.2$ & $4647 \pm 57$ & $5050-5600$ \\
\hline 8 & Wk-11056 & N15 & peat & $-29.9 \pm 0.2$ & $4733 \pm 68$ & $\begin{array}{c}5310-5600 \\
(5310-5590)\end{array}$ \\
\hline
\end{tabular}

* Samples with prefix "Wk" denote analyses performed by the Waikato University Radiocarbon Laboratory using Liquid Scintillation Counting; samples with prefix "NZA" denote analyses performed by the Rafter Radiocarbon Laboratory at the Institute of Geological and Nuclear Sciences using Accelerator Mass Spectrometry.

${ }^{1}$ Result based on Libby half-life of $5568 \mathrm{yr}$ with correction for isotopic fractionation applied

${ }^{2}$ Radiocarbon ages were calibrated to calendric years before 1950 using OxCal v3.9 software of Ramsey $(1995 ; 2003)$, incorporating atmospheric data from Stuiver et al. (1998). The age ranges shown in parentheses are posterior age distributions calibrated according to the stratigraphic order of the samples (see Figure 3.7).

Units to the south of fault zone 1 consist of blue-grey poorly sorted massive gravel (S1, S3, S8), blue-grey moderately-well sorted pebbly sand to fine sand (S2, S4-S6), dark brown fine peat and carbonaceous silt (S7) and banded dark to light brown fine peat (S9). Both the northern and southern units are mantled by an 
undeformed sequence of dark brown silt and fine peat (A1), brown-grey massive carbonaceous silt (B1), and blue-grey poorly sorted massive gravel (B2). The southern units interfinger, onlap, or are truncated southward against a series of poorly bedded or massive, poorly sorted, scarp-derived colluvial fans (G1-G5, G7, G9-G11, G13-G16, G18-G24), debris flow gravels and pebbly muds (G6, G8, G12, G17, G25, G26), and a much more well-indurated unit with very large angular clasts, termed "bedrock" during logging of the trench section. The lower gravel units are truncated by various sub-vertical strands of fault zone 2, most of which dip steeply toward the northwest, accordant with the regional dip of the Awatere Fault.

\section{$\underline{\text { Paleoseismic record preserved in the Upcot-1 trench }}$}

In the Upcot-1 trench, stratigraphic evidence for 5 events was observed. The ages of these events are given in Table 3.4, and the evidence used to differentiate between them is summarised below.

Table 3.4 - Age and time interval between surface-rupturing earthquake events recognised in the Upcot-1 trench. The arguments used in assigning a preferred age are outlined in the text.

\begin{tabular}{|c|c|c|c|c|}
\hline \multirow{2}{*}{ Event No. } & \multicolumn{2}{|c|}{$\begin{array}{c}\text { Maximum Age Range } \\
\text { (cal. yr B.P.; 95\% confidence) }\end{array}$} & $\begin{array}{c}\text { Preferred Age } \\
\text { (cal. yr B.P.) }\end{array}$ & $\begin{array}{c}\text { Interval from } \\
\text { previous event } \\
\text { (cal yr; 95\% confidence) }\end{array}$ \\
\cline { 2 - 5 } & Upper limit & Lower limit & $? 102$ & $1010 \pm 150$ \\
\hline 1 & 0 & $960-1260$ & $960-1260$ & $2140 \pm 400$ \\
\hline 3 & $960-1260$ & $1600-1890$ & $3000-3500$ & $1850 \pm 750$ \\
\hline 4 & $1600-1890$ & $4650-5300$ & $4650-5600$ & $0-1000^{*}$ \\
\hline 5 & $3380-3640$ & $5050-5600$ & $5050-5590$ & - \\
\hline
\end{tabular}

Limiting radiocarbon ages

${ }^{2}$ Result based on extrapolation of event horizon ages, assuming uniform sedimentation rates, and historical information on the 1848 earthquake

* A recurrence interval of 0 years only applies if evidence used to differentiate Events 4 and 5 actually applies to only one event.

Evidence for the most recent event (Event 1) includes a buried A horizon (unit A2), observed at the southeast end of both trench walls. Coseismic shaking during Event 1, possibly during initial deposition of unit B1, is inferred to have triggered failure of the topographic scarp, burying the contemporaneous soil with scarp-derived colluvium from the south (unit G1). This event was possibly the 1848 Marlborough earthquake as the burial of such a shallow soil horizon suggests a 
young event. As no obvious fault strands can be seen to have ruptured the contemporary ground surface at Upcot-1, this evidence, by itself, is not compelling and does not rule out the possibility of a storm-triggered scarp collapse. This earthquake interpretation is supported, however, by a surface-rupturing fault trace exposed in the Upcot-2 trench (discussed below).

A prominent unconformity observed on both walls between undeformed organic silt and fluvial gravel (units B1 and B2) and anticlinally-deformed organic silts and laminated peats (units N1-N6) provides evidence for Event 2. Similar to Event 1, this event does not appear to have ruptured the ground surface at the trench site. Instead, reverse slip on the fault zone 1 splays in the core of an anticline resulted in ductile deformation and tilting of the upper peat layers. This created a surface bulge which was later mantled and buried by fluvial gravel (B2), which thins over the top of the bulge. Event 2 therefore occurred before deposition of B2 and after deposition of $\mathrm{N} 2$. As $\mathrm{N} 2$ was undated, the maximum age for this event is provided by deposition of N5, dated at 1600-1890 cal. years B.P. by sample 2. Unit $\mathrm{N} 1$ is possibly the event horizon for this earthquake, as this unit appears to have been deformed just prior to its truncation by B2 (Figure 3.11). If Event 2 indeed postdates during deposition of N1, then the calibrated age of this event horizon (960-1260 cal. years B.P., sample 1) is the preferred age range for this event. Shaking associated with this earthquake possibly triggered deposition of a scarp-derived colluvial landslide (G3), burying the contemporary soil which is now exposed as a fossil soil horizon between G3 and G4 at the southeast end of the northeast wall.

An angular discordance between units N5 and N7 observed on both walls implies deformation sometime during the interval of N6 deposition, though the lack of bedding in this massive silt prevents further resolution of the timing of this tilting (Event 3). Down-dip projection of a scarp-derived colluvial wedge (G5) from the southeast end of the northeast wall indicates that this unit was deposited at approximately the same time as N6, suggesting deposition of this wedge during earthquake shaking related to this event. The truncation of at least four fault zone 2 strands below the base of G5 indicates surface rupture along fault zone 2 that was penecontemporaneous with the development of the unconformity between N5 and N7. This unconformity is an expression of forelimb rotation related to growth of fault zone 1's fault-propagation fold (the 'deformational bulge' in Figure 3.10 and 
Figure 3.11). Event 3 occurred before deposition of N5 at 1600-1890 cal. years B.P. (sample 2) and after deposition of N8 at 4650-5300 cal. years B.P. (sample 5). If G5 was deposited coseismically, then its stratigraphic position suggests Event 3 occurred during the middle stages of deposition of N6. The age of N6 is 3380-3640 cal. years B.P. (sample 3), and the age of G5 is 3830-4090 cal. years B.P. (sample 4). Given the uncertainty in differentiating the various scarp-derived colluvium units at the southeast end of the trench, the calibrated age of sample 4 is not used as a preferred age for Event 3. Instead, the broader age range of 3000-3500 cal. years B.P. is used. This preferred age for Event 3 is similar to the age of sample 3 in the middle of N6, as N6 is broadly syntectonic with respect to Event 3 and sample 3 lies at the downdip projection of the inferred colluvial wedge related to that event (G5).

Below the bench level on the southwest wall, there is an angular unconformity between fluvial gravel unit N7 (and its inferred correlative S3) and the underlying, finely laminated peats, silts and gravels (N8-N11). These older, more strongly deformed units also show an upward decrease in the amount of slip on fault zone 1. This geometry could be reasonably interpreted as representing multiple events, although it could also be a manifestation of the upward termination of fault zone 1 in the core of the fault-propagation fold that was tightened during Event 3. The geometry of the angular unconformity would require Event 4 to have post-dated the deposition of the more deformed unit N11, dated at 5050-5600 cal. years B.P. by sample 7, and to have predated deposition of N7/S3, a minimum age for which is 3380-3640 cal. years B.P., provided by sample 3 from the overlying unit N6. These samples yield a bracketing age range of 3380-5600 cal. years B.P. The topmost silt/peat layer (unit N8) was possibly deposited syntectonically with respect to Event 4. This unit is subparallel to the underlying, more strongly deformed peats and gravels on the southwest wall (Figure 3.11), which suggests this unit was deformed during this event. On the northeast wall, this unit appears to be subparallel to the unconformably overlying gravel unit N7/S3 (Figure 3.10). Unit N8 is therefore the event horizon for this earthquake, and the preferred age for this event is 4650-5600 cal. years B.P., using the age of deposition of unit N8, dated at 4650-5300 cal. years B.P. by sample 5 .

The truncation of lobate fluvial gravel (N12) against older debris flow gravels (G8, G13) across fault zone 1 provides evidence for Event 5. N12 thickens towards 
fault zone 1, and its presumed correlative (S8) thins on the upthrown (southeast) side of the fault, suggesting Event 5 ruptured fault zone 1 and was followed by deposition of a lobe of fluvial gravel (N12/S8) into the tectonic depression at the foot of the fault scarp. N12 onlapped onto the older debris-flow gravels, and has been truncated and displaced against these gravels by reverse movement across fault zone 1 during younger events. Event 5 occurred before deposition of N8 at 4650-5300 cal. years B.P. (sample 5) and after deposition of N15 at 5310-5600 cal. years B.P. (sample 8). The top contact of N12 is the inferred event horizon, which is dated by sample 7 to be 5050-5600 cal. years B.P. This is used as the preferred age range for Event 5.

\subsubsection{Upcot-2 trench}

The Upcot-2 trench was excavated in April 2003 at a site $\sim 50 \mathrm{~m}$ to the southwest of Upcot-1, where two fault scarps on either side of the contractional bend in the fault trace appear to coalesce. This trench was $<3 \mathrm{~m}$ deep, 15-18 $\mathrm{m}$ long and exposed mostly greywacke-derived indurated colluvium. Because this trench was excavated across the active channel, surface and groundwater flow rendered the upstream (northeast) wall unstable, and therefore only the southwest wall was logged. The graphical log of this wall is given in Figure 3.12.

Stratigraphy and structure of fault strands and sediments exposed in the Upcot-2 $\underline{\text { trench }}$

The Upcot-2 trench exposed a similar sedimentary sequence and set of fault zones to that of the Upcot-1 trench, though the basin is much narrower and shallower here, and only $\sim 2 \mathrm{~m}$ of fine-grained (ponded) sediments were exposed (detailed unit descriptions are given in Appendix B, Table B.3). At the northwest end of the trench, a series of colluvial units (N4, N5, N10-N13) dipping parallel to the ground surface represent hillslope deposits shed into the northern margin of the basin. Onlapping these are brown-grey carbonaceous silts (N1-N3, N9), poorly sorted muddy gravel (N6), massive gravel (N7a), and dark brown silt and peat (N7b, N8). These northern units are truncated by the principal strand of fault zone 1, which has a similar dip and reverse sense of dip-slip to fault zone 1 in the Upcot-1 trench. Reverse movement across fault zone 1 has displaced a series of well-indurated debris flows (S17), colluvial wedges (G1-G6) and bedrock units up the dip of the paleohillslope deposits to the northwest. These units have in turn been truncated by 


\section{Upcot-2 Trench: Southwest wall}

NW

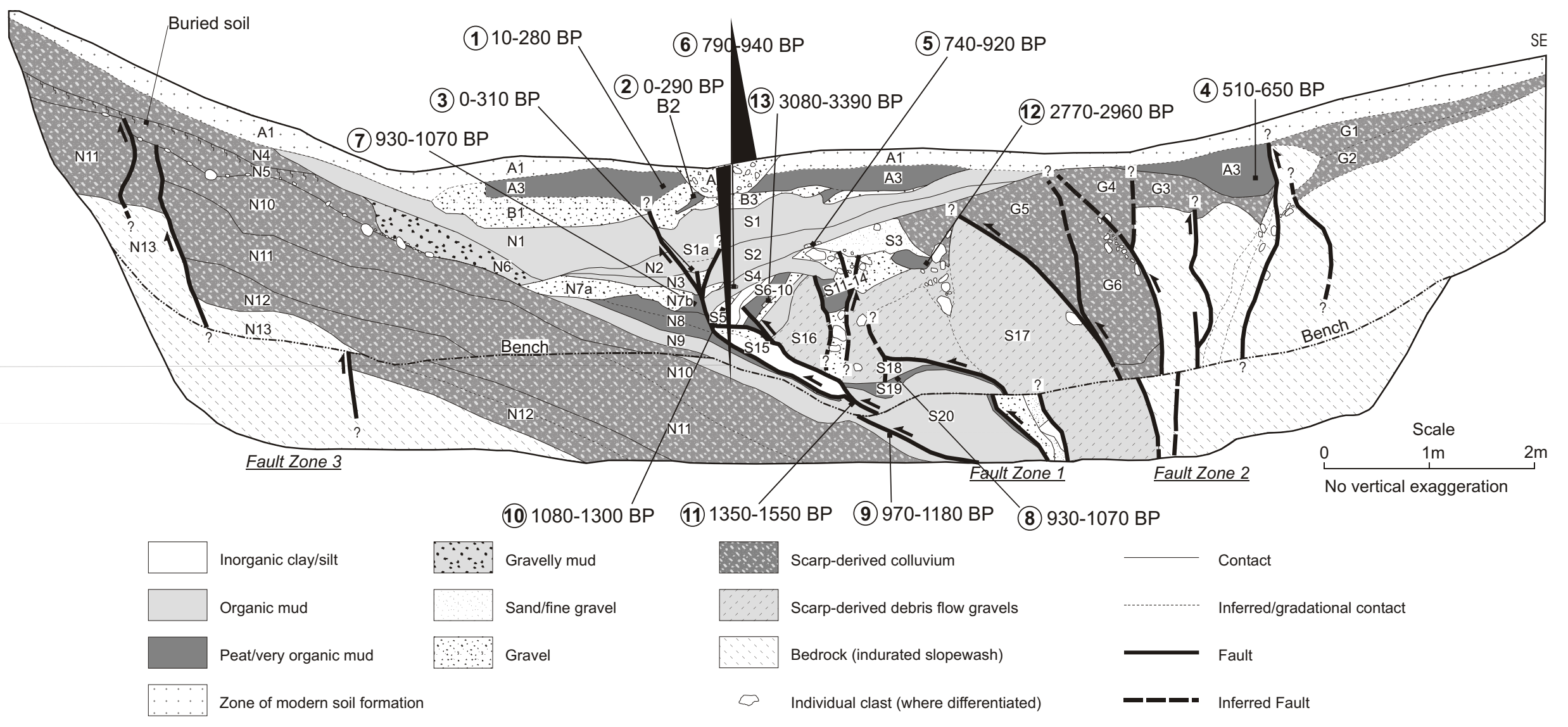


sub-vertical fault zone 2 strands, which appear to bifurcate from a single fault strand at depth. Overlying these gravel units are more continuous southern units, which consist of brown-grey carbonaceous silt (S1-S5, S10, S19, S20), massive inorganic silt (S6, S7, S15), dark brown fine peat (S8, S11, S13) and very poorly sorted silty gravel (S16, S18).

$\underline{\text { Paleoseismic record preserved in the Upcot- } 2 \text { trench }}$

Two events can be inferred from stratigraphic relations exposed in the Upcot2 trench. A total of 13 radiocarbon samples were submitted from this trench in an attempt to resolve stratigraphic relationships in this complexly mixed sequence of discontinuous units (Table 3.5).

Table 3.5 - Sample descriptions and results of radiocarbon analyses of carbonaceous samples collected from the Upcot-2 trench.

\begin{tabular}{|c|c|c|c|c|c|c|}
\hline $\begin{array}{c}\text { Sample } \\
\text { No. }\end{array}$ & $\begin{array}{l}\text { Laboratory } \\
\text { No.* }^{*}\end{array}$ & Unit & $\begin{array}{l}\text { Material } \\
\text { Dated }\end{array}$ & $\begin{array}{c}\delta^{13} \mathrm{C} \\
(\% \circ \text { wrt PDB) }\end{array}$ & $\begin{array}{c}\text { Conventional } \\
\text { Radiocarbon Age } \\
(\text { yr BP } \pm 1 \sigma)^{1}\end{array}$ & $\begin{array}{c}\text { Calibrated Age } \\
\text { (cal. yr BP; } \\
95 \% \text { confidence) }{ }^{2}\end{array}$ \\
\hline 1 & NZA 17809 & A3 & charcoal & -25.7 & $71 \pm 45$ & $0-280(10-280)$ \\
\hline 2 & Wk-13164 & B2 & wood & $-26.0 \pm 0.2$ & $186 \pm 34$ & $0-310(0-290)$ \\
\hline 3 & Wk-13166 & S1a & wood & $-27.2 \pm 0.2$ & $186 \pm 34$ & $0-310$ \\
\hline 4 & $\begin{array}{c}\text { Wk-13168 } \\
\text { (NZA 18187) }\end{array}$ & A3 & $\begin{array}{c}\text { soil \& } \\
\text { organic silt }\end{array}$ & $-28.7 \pm 0.2$ & $554 \pm 50$ & $510-650$ \\
\hline 5 & NZA 17808 & S2 & $\begin{array}{l}\text { charcoal \& } \\
\text { organic silt }\end{array}$ & -27.4 & $937 \pm 45$ & $730-940(740-920)$ \\
\hline 6 & NZA 17717 & S4 & wood & -27.1 & $939 \pm 40$ & $760-940(790-940)$ \\
\hline 7 & Wk-13584 & N7b & $\begin{array}{c}\text { wood \& } \\
\text { organic silt }\end{array}$ & $-28.3 \pm 0.2$ & $1100 \pm 36$ & $930-1070$ \\
\hline 8 & Wk-13165 & S19 & wood & $-29.5 \pm 0.2$ & $1102 \pm 36$ & $930-1070$ \\
\hline 9 & Wk-13585 & N9 & $\begin{array}{c}\text { wood \& } \\
\text { organic silt }\end{array}$ & $-29.5 \pm 0.2$ & $1158 \pm 36$ & $970-1180$ \\
\hline 10 & NZA 17703 & S5 & wood & -29.2 & $1286 \pm 45$ & $1080-1300$ \\
\hline 11 & Wk-13169 & N9 & $\begin{array}{c}\text { soil \& } \\
\text { organic silt }\end{array}$ & $-31.3 \pm 0.2$ & $1576 \pm 40$ & $1350-1550$ \\
\hline 12 & NZA 17702 & S13 & $\begin{array}{c}\text { wood } \\
\text { fragments }\end{array}$ & -25.1 & $2778 \pm 40$ & $2770-2960$ \\
\hline 13 & Wk-13167 & S7 & wood & $-26.6 \pm 0.2$ & $3067 \pm 46$ & $3080-3390$ \\
\hline
\end{tabular}

* Samples with prefix "Wk" denote analyses performed by the Waikato University Radiocarbon Laboratory using Liquid Scintillation Counting; samples with prefix "NZA" denote analyses performed by the Rafter Radiocarbon Laboratory at the Institute of Geological and Nuclear Sciences using Accelerator Mass Spectrometry.

${ }^{1}$ Result based on Libby half-life of 5568 yr with correction for isotopic fractionation applied

${ }^{2}$ Radiocarbon ages were calibrated to calendric years before 1950 using OxCal v3.9 software of Ramsey (1995; 2003), incorporating atmospheric data from Stuiver et al. (1998). The age ranges shown in parentheses are posterior age distributions calibrated according to the stratigraphic order of the samples (see Figure 3.7). 
The age of samples from the base of this trench $(\sim 1.5 \mathrm{ka})$ are much younger than those at a comparable depth in the Upcot-1 trench $(\sim 5.5 \mathrm{ka})$. The faster sedimentation rate in the Upcot-2 trench is in large part responsible for fewer events being recognised in that trench. The ages of the events identified in the Upcot-2 trench are given in Table 3.6, and the evidence used to differentiate between them is summarised below.

Table 3.6 - Age and time interval between surface-rupturing earthquake events recognised in the Upcot-2 trench. The arguments used in assigning a preferred age are outlined in the text.

\begin{tabular}{|c|c|c|c|c|}
\hline Event No. & \multicolumn{2}{|c|}{$\begin{array}{c}\text { Maximum Age Range } \\
\text { (cal. yr B.P.; 95\% confidence) }\end{array}$} & $\begin{array}{c}\text { Preferred Age } \\
\text { (cal. yr B.P.) }^{2}\end{array}$ & $\begin{array}{c}\text { Interval from } \\
\text { previous event } \\
\text { (cal. yr; 95\% confidence) }\end{array}$ \\
\cline { 2 - 4 } & Upper limit & Lower limit & $1090 \pm 110$ \\
\hline 1 & $10-280$ & $0-290$ & 102 & - \\
\hline 2 & $790-940$ & $1080-1300$ & $1080-1300$ & - \\
\hline
\end{tabular}

${ }^{1}$ Limiting radiocarbon ages

${ }^{2}$ Result based on stratigraphic and historical information on the 1848 earthquake

The most recent event (Event 1) ruptured the westernmost strand of fault zone 1 nearly to the contemporary ground surface. There, fault zone 1 extends at least as far as the base of A3 (the modern A horizon, $\sim 50 \mathrm{~cm}$ from the modern ground surface), and displaces the base of soil horizons B1/B3 by $30-40 \mathrm{~cm}$. Event 1 therefore occurred before deposition of A3 at 10-280 cal. years B.P. (sample 1) and after deposition of B3 at 0-290 cal. years B.P. (sample 2). These data are consistent with Event 1 being the 1848 Marlborough earthquake, at 102 cal. years B.P. (using 1950 A.D. as 0 cal. years B.P.). At the southern end of the trench, the truncation of A3 (younger than 510-650 cal. years B.P.; sample 4) by an eastern strand of fault zone 2 also possibly occurred during Event 1.

A prominent angular unconformity between a sequence of tilted, finely laminated silts, gravel and peat (S5-S10) and overlying, untilted carbonaceous silts (S2, S4) provides the basis for differentiation of the penultimate event (Event 2). This unconformity is possibly the same feature as the unconformity mapped in the Upcot-1 trench between units B2 and N1. Event 2 in the Upcot-2 trench involved surface rupture along fault zone 1 , and possibly fault zone 2 , with localised northwestward tilting $<25^{\circ}$ of units S5-S10. These units were subsequently bevelled and 
mantled by S2 and S4. Event 2 therefore occurred before deposition of S4 at 790940 cal. years B.P. (sample 6) and after deposition of S5 at 1080-1300 cal. years B.P. (sample 10). The preferred age for this event is 1080-1300 cal. years B.P., assuming uniform sedimentation rates between samples 10 and 6 , and based on the inference that sample 10 represents the event horizon for this earthquake.

Displacement across fault zone 1 increases with depth in the trench, suggesting more events have ruptured the trench site than the two events outlined above. Unfortunately, the occurrence of several age reversals from radiocarbon samples throughout the trench, especially samples 12 and 13, make reliable differentiation of these events problematical. These age reversals are most likely due to recycling of older detrital wood fragments into younger peat accumulations.

\subsubsection{Synthesis of results from the Upcot trenches}

Graphical representation of the timing of earthquakes identified in the Upcot1 (Figure 3.13a) and Upcot-2 (Figure 3.13b) trenches show obvious coincidences in the timing of the two most recent events at Upcot Saddle. Combining bracketing age data from both trenches can increase the statistical precision of the age of individual earthquake events relative to that derived from age data in only one trench in isolation (Figure 3.13c). Surface rupture from the 1848 earthquake was only observed directly on fault zone 1 in the Upcot-2 trench (Event 1), so the maximum and preferred age ranges for Event 1 are derived from data in Upcot- 2 only. The timing of the penultimate events from both trenches overlap, and therefore both probably represent rupture during the same event (Event 2). This event is tightly constrained to be no younger than 960 cal. years B.P. by sample 1 in Upcot-1, and no older than 1300 cal. years B.P. by sample 10 in Upcot-2. Similarly, the preferred age (the projected age of the event horizon) is constrained to be no younger than 1080 cal. years B.P. by Upcot-2 and no older than 1300 cal. years B.P. by Upcot-1. As only the last two events were identified in the Upcot-2 trench, the ages of Events 3-5 remain unchanged from those derived above for Upcot-1.

\subsubsection{Integrated paleoseismic history for the eastern section}

The timing of surface ruptures on the Awatere Fault at Upcot Saddle (Figure 3.14a) can be compared to the Holocene surface rupture history for the eastern section at Lake Jasper (Figure 3.14b) can be compared with these at Upcot Saddle 


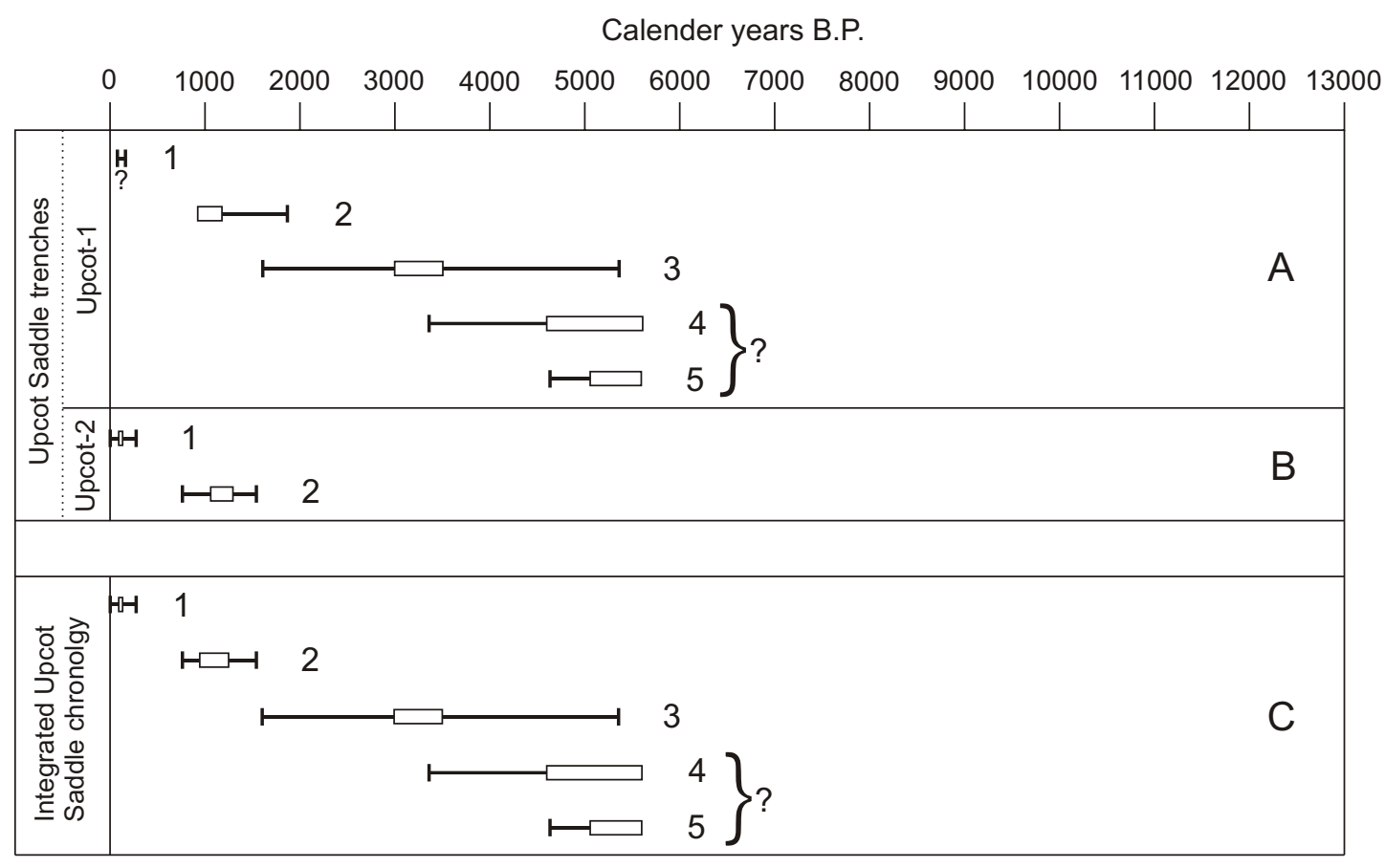

Figure 3.13a-c Earthquake chronologies for the eastern section of the Awatere fault at Upcot Saddle. The boxes indicate the most probable time of faulting (the 'preferred age') as interpreted from stratigraphic and historical evidence, and the bracketing limits represent the maximum permissible limits for faulting events as determined from ${ }^{14} \mathrm{C}$ dating. (A) Chronology of Holocene surfacerupturing paleoearthquakes on the eastern section identified in the Upcot-1 trench. (B) Chronology of paleoearthquakes identified in the Upcot-2 trench. (C) Holocene surface rupture chronology integrating results from the two Upcot trenches. 
Calender years B.P.

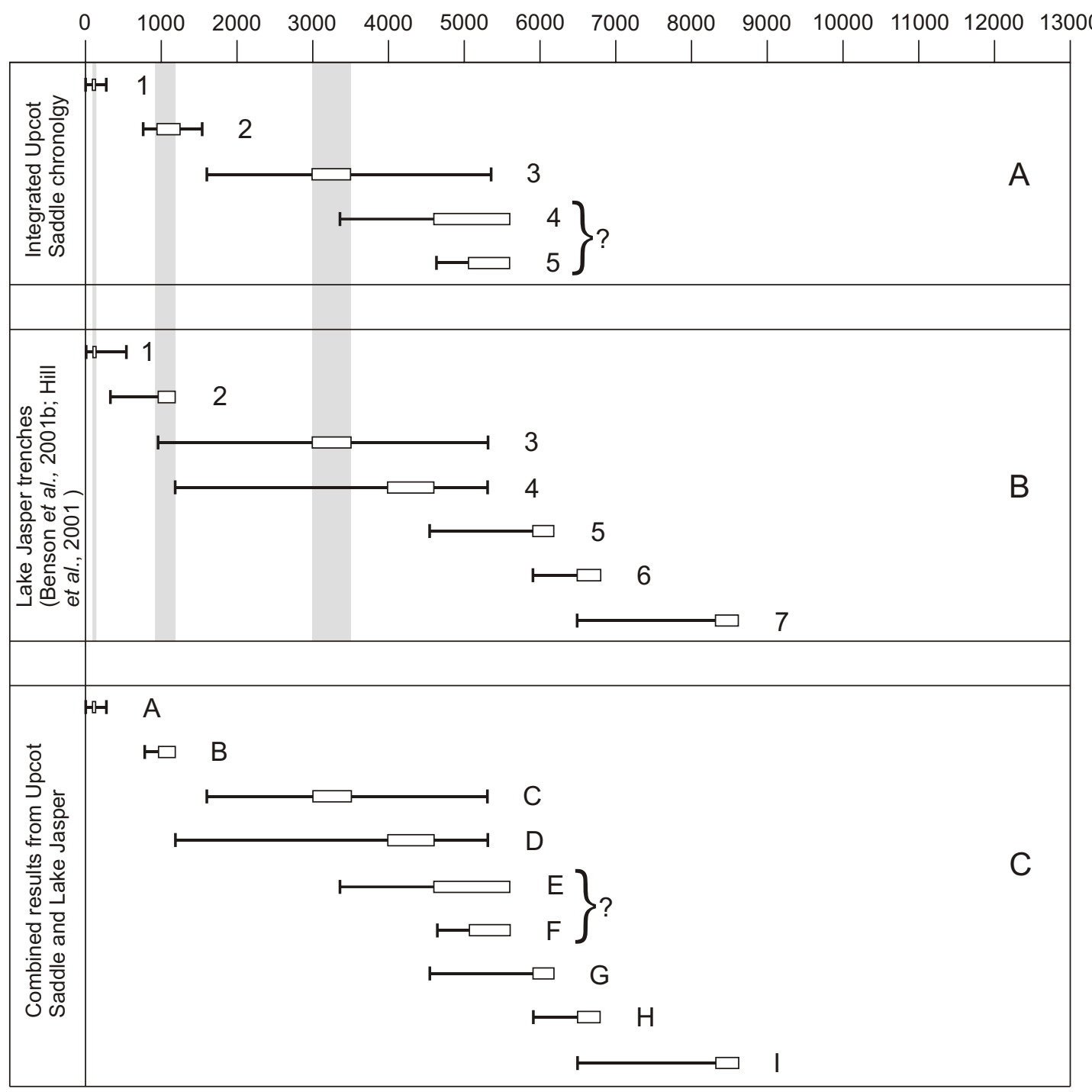

Figure 3.14a-c Earthquake chronologies for the eastern section of the Awatere fault. The boxes indicate the most probable time of faulting (the 'preferred age') as interpreted from stratigraphic and historical evidence, and the bracketing limits represent the maximum permissible limits for faulting events as determined from ${ }^{14} \mathrm{C}$ dating. (A) Holocene surface rupture chronology integrating results from the two Upcot trenches. (B) Combined Holocene surface rupture chronology from the Lake Jasper trenches (Benson et al., 2001; Hill et al., 2001). The shaded bars indicate events identified at Upcot Saddle that occurred at a similar time to events identified at Lake Jasper. (C) Holocene surface rupture chronology for the eastern section of the Awatere Fault, integrating results from the Upcot Saddle and Lake Jasper trench sites. 
$\sim 55 \mathrm{~km}$ to the southwest. A combined earthquake chronology for the eastern section of the Awatere Fault is summarised in Table 3.7 and presented graphically in Figure $3.14 \mathrm{c}$.

Table 3.7 - Age ranges and intervals for the combined record of recognisable events from the Upcot1 and Upcot-2 trenches (this study) and the Lake Jasper trenches (Benson et al., 2001; Hill, et al., 2001). The arguments used in assigning a preferred age are outlined in the text.

\begin{tabular}{|c|c|c|c|c|}
\hline \multirow[t]{2}{*}{ Event No. } & \multicolumn{2}{|c|}{$\begin{array}{c}\text { Maximum Age Range } \\
\text { (cal. yr B.P.; } 95 \% \text { confidence) }\end{array}$} & \multirow[t]{2}{*}{$\begin{array}{l}\text { Preferred Age } \\
\text { (cal. yr B.P.) }\end{array}$} & \multirow{2}{*}{$\begin{array}{c}\text { Interval from } \\
\text { previous event } \\
\text { (cal. yr) }\end{array}$} \\
\hline & Upper limit & Lower limit & & \\
\hline A & 0 & $0-310$ & 102 & $980 \pm 100$ \\
\hline B & $790-940$ & $980-1180$ & $980-1180$ & $2170 \pm 350$ \\
\hline $\mathrm{C}$ & $1600-1890$ & $4550-5300$ & $3000-3500$ & $1050 \pm 550$ \\
\hline D & $980-1180$ & $4550-5300$ & $4000-4600$ & $1000 \pm 600$ \\
\hline$E$ & $3380-3640$ & $5310-5600$ & $5000-5600$ & $745 \pm 435$ \\
\hline $\mathrm{F}$ & $4550-5300$ & $5910-6180$ & $5910-6180$ & $605 \pm 235$ \\
\hline $\mathrm{G}$ & $5910-6180$ & $6490-6790$ & $6490-6790$ & $1820 \pm 220$ \\
\hline $\mathrm{H}$ & $6490-6790$ & $8330-8610$ & $8330-8610$ & - \\
\hline
\end{tabular}

Here, it is assumed that statistical (95\%) overlaps in the timing of events at each site record large single events that ruptured the entire eastern section. Where reasonable, the preferred age ranges (the most probable time of faulting as estimated by extrapolating event horizon ages) are used in these correlations. Events identified at one site with no obvious correlative at the other site are here considered to be separate events. These events may not have ruptured the entire eastern section, or they may not be recorded by the trench stratigraphy at every site. The combined data sets provide a more complete surface rupture history of the eastern section than taking any of the trenches in isolation, and together document nine surface rupturing earthquakes on this part of the Awatere Fault since 8330-8610 cal. years B.P. (Figure $3.14 \mathrm{e})$.

Evidence for an 1848-age surface rupture (Event A) was observed at both the Upcot and Lake Jasper sites, in accordance with historical observations that this earthquake ruptured the entire $\sim 100 \mathrm{~km}$ traceable length of the eastern section (Grapes et al., 1998). Event 2 at Upcot Saddle occurred between 960-1300 cal. years 
B.P., which is very similar to the age of Event 2 at Lake Jasper (980-1180 cal. years B.P.), implying that both sites record the same event. This combined event (Event B) is constrained by the Upcot trenches to be no younger than 790 cal. years B.P., and is constrained by the Jasper trenches to be no older than 1180 cal. years B.P. The preferred age of Event 2 from the Jasper-1 trench is the narrower interval (Benson et al., 2001), and is therefore adopted as the preferred age range for Event B on the eastern section of the Awatere Fault.

The bracketing ages of Event 3 at Lake Jasper overlap with the bracketing ages of Event 3 at Upcot Saddle, suggesting both sites record the same event (Event C). This event is constrained by the Upcot- 1 trench to be no younger than $1600 \mathrm{cal}$. years B.P. The maximum bracketing age at both sites is 5300 cal. years B.P. The preferred age of Event 3 at Lake Jasper (3000-3500 cal. years B.P.) is indistinct from the preferred age of Event 3 from the Upcot-1 trench (also 3000-3500 cal. years B.P.), and therefore this age range is used for the preferred age of Event $C$ on the eastern section.

Earthquakes that are older than Event 3 show obvious statistical correlations between the bracketing ages of rupture events identified at Lake Jasper. Despite these correlations, individual events inferred at Upcot Saddle cannot be uniquely correlated to only one event at Lake Jasper because of broad bracketing age ranges at both sites. For example, the maximum age range of Event 4 from Upcot-1 overlaps with the bracketing ages of Events 3, 4 and 5 at Lake Jasper (Figure 3.14). Because of these non-unique overlaps, Events 4 and 5 identified at Lake Jasper do not help to refine the age ranges of Events 4 and 5 identified at Upcot Saddle. Consequently, Events 4 and 5 at Upcot Saddle are considered to be separate events from Events 4 and 5 at Lake Jasper. Event 4 at Lake Jasper has the youngest preferred age of these four events, and is therefore the next-oldest earthquake on the eastern section (Event D). Events 4 and 5 from the Upcot- 1 trench would be Events E and F, respectively, and Event 5 at Lake Jasper is Event G.

The Lake Jasper paleoseismic record is longer than the Upcot Saddle record, and three events from the Jasper-1 trench (Events 4, 5 and 6) are older than any identified from the Upcot-1 trench (Benson et al., 2001). These three events are included here as Events G, H and I. 


\subsection{DISCUSSION}

\subsubsection{Earthquake recurrence intervals}

A requisite element of seismic hazard assessment is an estimate of the recurrence of large earthquakes. Recurrence intervals can be calculated individually from the calibrated age difference between paleoearthquakes or statistically from the division of a mean per-event displacement by the fault's slip rate (McCalpin, 1996b). Recurrence intervals for the Molesworth and eastern sections were calculated using both methods, and are outlined below.

Recurrence intervals between paleoearthquakes identified in the trenches were calculated from the most probable time of faulting (the 'preferred' age limits). The radiocarbon ages that bracket individual rupturing events were calibrated at the $95 \%$ confidence limit. The total interval between any two events was calculated by subtracting the minimum age of the younger event from the maximum age of the older as one extreme, and the maximum age of the younger event from the minimum age of the older event as the other extreme. As the radiocarbon sample ages were calibrated to calendar years B.P. at the $95 \%$ confidence limit, the recurrence intervals are assumed also to capture $95 \%$ of the age uncertainty, and are thus quoted as mean values with standard deviations that capture all the possible ages within that interval.

\section{$\underline{\text { Molesworth section }}$}

The identification of ten earthquakes between $0-310$ and $14500 \pm 1500$ years B.P. (Table 3.2) yields a mean recurrence interval of $1435 \pm 165$ cal. years. This is most likely a maximum interval due to incompleteness of the paleoseismic record in the lower part of the Saxton-2 trench (older than Event 8), where massive alluvial gravels and fine-grained silt only record two events with large intervals between them (Events 9 and 10). Individual return times between earthquakes younger than these two events are non-uniform, and range from $<130$ years between Events 2 and 3 to $1750 \pm 320$ cal. years between Events 4 and 5. The formal uncertainty of these return time intervals is $95 \%$, which represents the confidence limit of the ${ }^{14} \mathrm{C}$ age distributions that bracket individual paleoearthquakes. These return times appear to increase with increasing age, dividing the paleoseismic record into two 'clusters' of events. The older cluster encompasses Events 8 to Event 4, and has recurrence intervals $<1750 \pm 320$ cal. years. The younger cluster spans Event 4 to the present, 
with an average recurrence of $<570 \pm 90$ cal. years. At face value, this increase in frequency suggests seismicity of the Molesworth section has increased in the late Holocene. Knuepfer (1992) and McCalpin (1996a) both noted a late Holocene reversal in the sense of throw of the Saxton River terraces across the Awatere Fault, which may have occurred at a similar time to this increase in seismicity (Chapter 5). Although there may be no direct connection between these two observations, it might be speculated there is a causal relationship between these phenomena. Further studies at other sites along the Molesworth section are needed to refine such an hypothesis. Alternatively, the increase in earthquake frequency may merely be due to changes in the preservation potential of the sagpond stratigraphy, as there are few well-bedded carbonaceous horizons older than $\sim 3$ ka that constrain faulting events compared to the finely laminated upper-bench stratigraphy.

Calculating a statistical mean recurrence interval for the Molesworth section from strike-slip rates and mean per-event displacements yields similar results to those calculated between individual paleoearthquakes. New OSL dating of the Saxton River terraces show the slip rate of this part of the Molesworth section has been constant at $\sim 5.5 \pm 1.5 \mathrm{~mm} / \mathrm{a}$ since the late Quaternary (Chapter 5). Using Geyh and Schliecher's division rule for variables with unequal standard deviations (McCalpin, 1996b), and assuming a maximum per-event displacement of 6-8 m (McCalpin, 1996a), these slip rates yield a maximum recurrence interval of 1270 \pm 390 years. This is possibly an overestimated recurrence as the per-event displacements at the easternmost end of the Molesworth section may be $<4 \mathrm{~m}$ (Chapter 4). This reduced estimate of coseismic slip yields a recurrence interval of $550 \pm 230$ years, which compares favourably to the mean late Holocene interval. Most importantly, the new paleoearthquake data from the Saxton-2 trench significantly decrease the recurrence intervals calculated using McCalpin's paleoearthquake data, which are between $\sim 1000-2000$ years (between 2-4 events since 4.5 ka B.P.).

\section{$\underline{\text { Eastern section }}$}

The calibrated ages of the five paleoearthquakes identified in the Upcot Saddle trenches are separated by intervals that range from $1010 \pm 150$ to $1850 \pm 750$ cal. years (Table 3.4 and Table 3.6). Benson et al. (2001) and Hill et al. (2001) 
reported similar non-uniform recurrence intervals for the eastern section at Lake Jasper between $605 \pm 235$ and $2170 \pm 350$ cal. years. Integrating the two datasets yields a more complete paleoseismic record for the eastern section, with nine events since 8330-8610 cal. years B.P. occurring at a mean recurrence of $930 \pm 15$ cal. years. The individual intervals between these integrated events are non-uniform, and range from $605 \pm 235$ to $2170 \pm 350$ cal. years (Table 3.7). Unlike the Molesworth section, these recurrence intervals show no decrease through the Holocene.

Calculating a statistical mean recurrence interval for the eastern section from strike-slip rates and mean per-event displacements produces a shorter mean recurrence interval than that calculated individually from the calibrated ages of paleoearthquakes. Strike-slip rates on the eastern section have been relatively constant at $6 \pm 2 \mathrm{~mm} / \mathrm{a}$ since $\sim 21 \mathrm{ka} \mathrm{B.P.} \mathrm{(Benson} \mathrm{et} \mathrm{al.,} \mathrm{2001).} \mathrm{The} \mathrm{mean} \mathrm{recurrence}$ interval calculated using these slip rates and the mean coseismic horizontal displacement estimate of $5.3 \pm 1.6 \mathrm{~m}$ for the 1848 earthquake (Chapter 4) is $880 \pm 400$ years. The mean interval calculated from the paleoseismic trenches is $\sim 1000$ years, within the error of this slip rate-based estimate. In this interval, $\sim 6 \mathrm{~m}$ of elastic strain would accumulate using Benson et al.'s (2001) slip rates of $6 \pm 2 \mathrm{~mm} / \mathrm{a}$. This agrees with the mean coseismic horizontal displacement of $5.3 \pm 1.6 \mathrm{~m}$ that is attributed to the 1848 earthquake (Chapter 4).

\subsubsection{Rupture segmentation of the Awatere Fault}

Previous neotectonic and paleoseismic research suggested that the eastern and Molesworth sections have behaved as discrete rupture segments at least during the 1848 earthquake (e.g., McCalpin, 1996a; Grapes et al., 1998; Little et al., 1998; Benson et al., 2001; Hill et al., 2001). New mapping of this fault junctions region (Chapter 2) shows this feature to be a low angle $\left(10-15^{\circ}\right)$ and narrow, elongate $(<3$ $\mathrm{km}$ ) fault intersection that is expressed by fresh-looking scarps and fissures. The conspicuously low-angle geometry of this fault strand intersection might mechanically favour the simultaneous rupture of both sections (e.g., Barka and Kadinsky-Cade, 1988), an observation which runs counter to interpretations that were based on previous available paleoseismic data. In the following section, the new paleoseismic data collected as part of this study is used to investigate the influence of the fault sections junction on the rupturing behaviour of the Awatere Fault. The detailed surface rupture chronologies presented earlier for each fault 
section span both sides of the fault junctions region, and thus provide a qualitative means of determining whether past ruptures have broken across the junction.

The new, integrated rupture chronologies for the eastern and Molesworth sections show well-constrained overlaps (at 95\% confidence) in the occurrence of paleoearthquakes at 5750-6180, 4250-4600, 3000-3500 and 930-1180 cal. years B.P. (Figure 3.15). Significantly, a very young surface rupture on the Molesworth section at Saxton River may have occurred at the same time as the 1848 Marlborough earthquake on the eastern section, as its age is statistically indistinct from that date. These overlaps are based on the most probable age of faulting (estimated by extrapolation of event horizon ages under the assumption of constant sedimentation rates); comparing the bracketing ages of events on both fault sections would result in identification of more overlapping events that just the five mentioned above.

The overlapping ages of five paleoearthquakes across the fault junction suggest the two geometric sections are mechanically linked, an observation that counters previous interpretations of the influence of the fault junctions region on Awatere Fault seismicity. While the relative timing of these correlated ruptures cannot be resolved on the basis of available ${ }^{14} \mathrm{C}$ data, their close timing allows the possibility that the two fault sections rupture synchronously across the Mt Chisholm fault junction in large magnitude earthquakes. These observations are accordant with paleoseismic, historical and modern observations of large-magnitude strike slip earthquake ruptures that broke across apparent structural discontinuities (e.g., Sieh et al., 1993; Grant and Sieh, 1994; Zachariasen and Sieh, 1995; Rubin, 1996; Rockwell et al., 2000; Barka et al., 2002; Lettis et al., 2002). These studies suggest that apparent rupture boundaries defined on the basis of the geometric segmentation of the fault may not act as effective barriers to rupture propagation. In this context, the statistically inseparable age of the most recent event on the Molesworth section relative to the $\mathrm{M}_{\mathrm{w}} \sim 7.51848$ earthquake, and the fresh nature of fissures and scarps on the Molesworth section, suggest both fault sections may have ruptured simultaneously in 1848 .

An alternative explanation for the indistinct ages of the most recent event on the Molesworth and eastern sections, and the close timing of older earthquakes, would be that these events were not simultaneous ruptures of both fault sections, as 


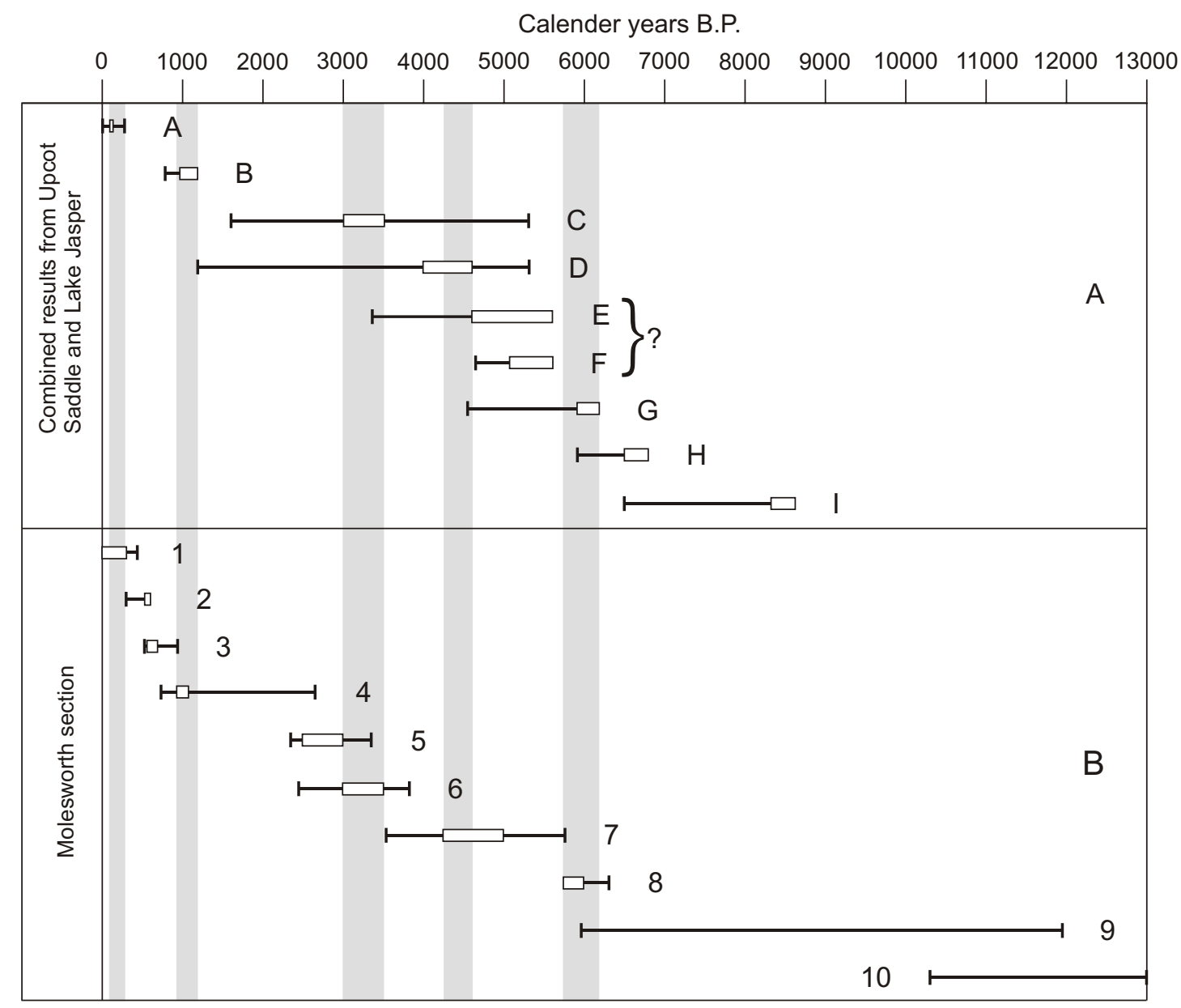

Figure 3.15a-b Earthquake chronologies for the Awatere fault. The boxes indicate the most probable time of faulting (the 'preferred age') as interpreted from stratigraphic and historical evidence, and the bracketing limits represent the maximum permissible limits for faulting events as determined from ${ }^{14} \mathrm{C}$ dating. (A) Chronology of late Quaternary surface-rupturing paleoearthquakes on the eastern section of the Awatere Fault. (B) Chronology of late Quaternary surface-rupturing paleoearthquakes on the Molesworth section of the Awatere Fault. The shaded bars indicate events on the eastern section that occurred at a similar time to events on the Molesworth section. 
the resolution of available paleoseismic dating techniques cannot distinguish between a simultaneous, large rupture of two fault sections and two separate ruptures that are closely spaced in time (McCalpin, 1996b). The fault junction may indeed act as an effective barrier to rupture propagation, in accordance with previous interpretations (e.g., Grapes et al., 1998). The close timing of rupture on these adjacent fault sections implies they are not independent rupture segments, however, and that a propagating dynamic rupture on one section increased the shear stress on the adjacent section and eventually triggered rupture there. Such a model has been proposed for a sequence of seven earthquakes in the Marlborough fault system since the 1848 event (Doser and Robinson, 2002) and a sequence of ten earthquakes on the North Anatolian Fault between 1939-1992 (Stein et al., 1997).

\subsubsection{Implications for seismic hazard assessment}

Despite the Awatere Valley being relatively sparsely populated, the Awatere Fault still poses a significant ground-shaking hazard to central New Zealand, as demonstrated by the 1848 earthquake, which caused extensive damage to buildings in Wellington city (Eiby, 1980). The most recent evaluation of seismic hazard for New Zealand includes the Awatere Fault as two active fault sources (Stirling et al., 2002a). The eastern section (termed "Awatere NE" by Stirling et al., 2002a) is expected to rupture in earthquakes of $\mathrm{M}_{\mathrm{w}} \sim 7.5$, with a recurrence interval of 1000 years. New paleoseismic data from this study do not significantly change these parameters, though the earthquake record from the Upcot trenches supplements the pre-existing paleoseismic record of Benson et al. (2001) and Hill et al. (2001). The Molesworth section (termed "Awatere SW" by Stirling et al., 2002a) is estimated to rupture in earthquakes of $\mathrm{M}_{\mathrm{w}}<7.5$ every 2930 years. The new paleoseismic data from the Saxton-1 trench on the Molesworth section significantly reduce the recurrence interval quoted by Stirling et al. (2002a), effectively increasing the seismic hazard posed by the Molesworth section.

The nature of the putative linkage between the eastern and Molesworth sections could also affect the seismic hazard posed by the Awatere Fault. If the eastern and Molesworth sections are linked, and rupture simultaneously in large earthquakes, then the recurrence interval for the Awatere Fault as a whole would increase if any two individual events identified on each fault section were actually 
the same event. This would correspondingly decrease the probability of rupture. If ruptures can propagate across the junction, then the rupture length is likely to be larger than $110 \mathrm{~km}$, which is the length of the well-preserved eastern section trace that ruptured in 1848 (Grapes et al., 1998). This length forms the basis for the 'characteristic' magnitude estimate of $\mathrm{M}_{\mathrm{w}}$ 7.5. If single earthquakes rupture both fault sections, the magnitude could increase to $\mathrm{M}_{\mathrm{w}} \sim 7.7$, using the regressions scaling rupture dimensions against moment magnitude of Wells and Coppersmith (1994) and Stirling et al. (2002a), as the combined rupture length increases to $<170 \mathrm{~km}$. Under this scenario, the seismic hazard of the Awatere Fault as a whole is reduced, despite the larger magnitude, because only one seismic source would be required to rupture both fault sections.

The alternative hypothesis that the two sections are independent yet trigger rupture could potentially increase the seismic hazard as two smaller, sequential events would double the exposure for sites close to the fault such as Seddon and Blenheim. Similarly, under this scenario the probability of rupture on one section would be dependent on the probability of the adjacent section rupturing. If one section were to rupture, the time until the next large earthquake on the adjacent section could be significantly altered depending on the location and orientation of the adjacent section with respect to stress shadows and stress-triggering zones associated with the preceding rupture (e.g., Stein, 1999).

\subsection{CONCLUSIONS}

From cross-cutting and differential tilting relationships observed between stratigraphic units exposed in a new paleoseismic trench at Saxon River, $18 \mathrm{~km}$ to the west of the fault junctions region on the Molesworth section of the Awatere Fault, up to ten surface-rupturing paleoearthquakes since $14.5 \pm 1.5 \mathrm{ka}$ B.P. are identified. These events are separated by a mean recurrence interval of $1435 \pm 165$ cal. years, which is most likely a maximum interval due to an incomplete event record preserved by the oldest units in the trench. This is similar to the mean interval of $1270 \pm 390$ years calculated using strike-slip rates and mean per-event displacement estimates. Intervals between individual events are non-uniform, and range from $<130$ to $1750 \pm 320$ cal. years. An apparent prominent increase in earthquake frequency during the late Holocene is contemporaneous with an apparent reversal in 
the upthrown side of the active fault trace, and, if representative of the current seismic pattern, would apparently increase the seismic hazard posed by the Molesworth section.

Near Upcot Saddle, two new trenches were excavated $\sim 12 \mathrm{~km}$ to the northeast of the fault junctions region on the eastern section. Up to five paleoearthquakes since 5310-5600 cal. years B.P. are identified from these trenches. The most recent event ( $<300$ cal. years B.P.) is inferred to be the 1848 Marlborough earthquake. These events are separated by a maximum mean recurrence interval of $1045 \pm 55$ cal. years, though the intervals between individual events are non-uniform, and range from $1010 \pm 150$ to $1850 \pm 750$ cal. years.

When the Upcot events are combined with a detailed surface rupture chronology for the eastern section near Lake Jasper, nine events since 8330-8610 cal. years B.P. are identified. These events are separated by a maximum mean recurrence interval of $930 \pm 15$ cal. years. This is within error of the mean interval of $880 \pm 400$ years calculated from strike-slip rates and the mean coseismic horizontal displacement of $5.3 \pm 1.6 \mathrm{~m}$ attributed to the 1848 earthquake. The intervals between individual events from the expanded eastern section paleoearthquake chronology are non-uniform, and range from $605 \pm 235$ to $2170 \pm 350$ cal. years. Unlike the Molesworth section, there is no apparent systematic change in the frequency of seismicity on the eastern section.

Five surface rupturing events on the eastern section, including the 1848 Marlborough earthquake, are coincident with events on the Molesworth section at Saxton River. The age ranges of these overlaps are 5750-6180, 4250-4600, 30003500, 930-1180 and 0-310 cal. years B.P. Near-synchronous earthquakes on opposing sides of a fault section junction suggest that this apparent structural discontinuity may not act as an effective barrier to rupture propagation, allowing the possibility that the two fault sections are mechanically linked across the fault junction, and that large magnitude earthquakes $\left(\mathrm{M}_{\mathrm{w}} \sim 7.5\right)$ rupture both fault strands simultaneously. Alternatively, these closely-timed events may have been separate events that occurred within a time period narrower than the resolution provided by available radiocarbon dating. Stress-loading of adjacent faults during rupture of a principal fault section may be responsible for triggering rupture of those faults. The 
nature of the linkage between the eastern and Molesworth sections has important bearings on the seismic hazard posed by the Awatere Fault as a whole, depending on whether the two fault sections rupture simultaneously in large earthquakes. 


\title{
4. REFINED SLIP DISTRIBUTION AND MOMENT MAGNITUDE FOR THE 1848 MARLBOROUGH EARTHQUAKE, NEW ZEALAND
}

\begin{abstract}
The Awatere Fault is an important element of the obliquely-convergent plate boundary zone in northeastern South Island, New Zealand, and is comprised of two geometrically defined sections that join across a complex fault junction in the upper Awatere Valley. A large-magnitude $\left(\mathrm{M}_{\mathrm{w}} 7.5+\right)$ earthquake in 1848 on the Awatere Fault provides the historical context for investigating the influence of a fault-section junction on the rupturing behaviour of a major strike-slip fault. Preliminary historical and paleoseismic data have previously been interpreted as suggesting that this junction has acted as a barrier to dynamic rupture propagation, a conclusion that has not been substantiated by further neotectonic or paleoseismic research. This study (1) documents the coseismic slip distribution along the previously-unmapped trace in the vicinity of the fault junction and presents refined surface rupture length and mean coseismic displacement estimates of $>100-110 \mathrm{~km}$ and $5.3 \pm 1.6 \mathrm{~m}$, respectively; (2) re-evaluates the moment magnitude of the earthquake to $M_{w}=7.4-7.7$; and (3) presents the hypothesis that the eastern and Molesworth sections are mechanically linked, and that they ruptured simultaneously in 1848. Addition of the smallest and youngest geomorphic displacement measurements from the Molesworth section into a combined displacement-length curve for both sections is consistent with the hypothesis that there was a mean cumulative-slip maximum in 1848 of $8.1 \pm 2.0 \mathrm{~m}$ in the vicinity of the junction, which implies that this earthquake may have nucleated in this area. On the basis of similar rupture lengths and geomorphic displacements, it is also inferred that the penultimate event had a similar moment magnitude to the 1848 earthquake.
\end{abstract}




\subsection{INTRODUCTION}

In northeast South Island, New Zealand, obliquely convergent relative motion between the Pacific and Australian Plates is accommodated through a zone of dextral-slip faults. Of these, the Awatere Fault comprises two geometric sections (the eastern and Molesworth sections; see Figure 4.1), which differ by $20-25^{\circ}$ in strike and are separated by a conspicuous fault junctions region near the Molesworth Station homestead in the upper Awatere Valley. Previous neotectonic and paleoseismic research indicate this junction may be a significant mechanical barrier to earthquake rupture propagation, thus influencing the magnitude of seismicity on the Awatere Fault. The eastern section last ruptured in the $\mathrm{M}_{\mathrm{w}} \sim 7.51848$ Marlborough earthquake (Grapes et al., 1998), which was one of the very few largemagnitude historical earthquakes in New Zealand; the others being the M8.2-8.3 1855 earthquake on the Wairarapa Fault (Grapes, 1999) and the M7-7.3 North Canterbury earthquake in 1888 on the Hope Fault (Cowan, 1991).

The 1848 earthquake on the Awatere Fault provides the opportunity to increase our understanding of the effect of fault discontinuities on a major strike-slip fault. Contemporary accounts indicate that the surface rupture of this earthquake extended along the eastern section from the coast at White Bluffs to at least Barefell Pass, a distance of $\sim 110 \mathrm{~km}$. Importantly, it appears this earthquake did not trigger rupture of the Molesworth section, suggesting the two differently striking strands of the fault acted as mechanically distinct rupture segments during this earthquake. A similar pattern is inferred for older events by Benson et al. (2001) and Hill et al. (2001), who note the penultimate event on the eastern section does not correlate with the penultimate event on the Molesworth section (McCalpin, 1996a). The data thus suggest the fault junction has been an important mechanical boundary controlling the location and magnitude of seismicity on the Awatere Fault.

Despite recent neotectonic and paleoseismic research (e.g., Grapes et al., 1998; Little et al., 1998; Benson et al., 2001; Hill et al., 2001), the total length of the 1848 rupture and the slip distribution along this length are not well-constrained. The primary goal of this study, therefore, is to establish the maximum traceable length of the 1848 surface rupture, and to determine the coseismic slip distribution by the identification and measurement of small geomorphic displacements related to that 


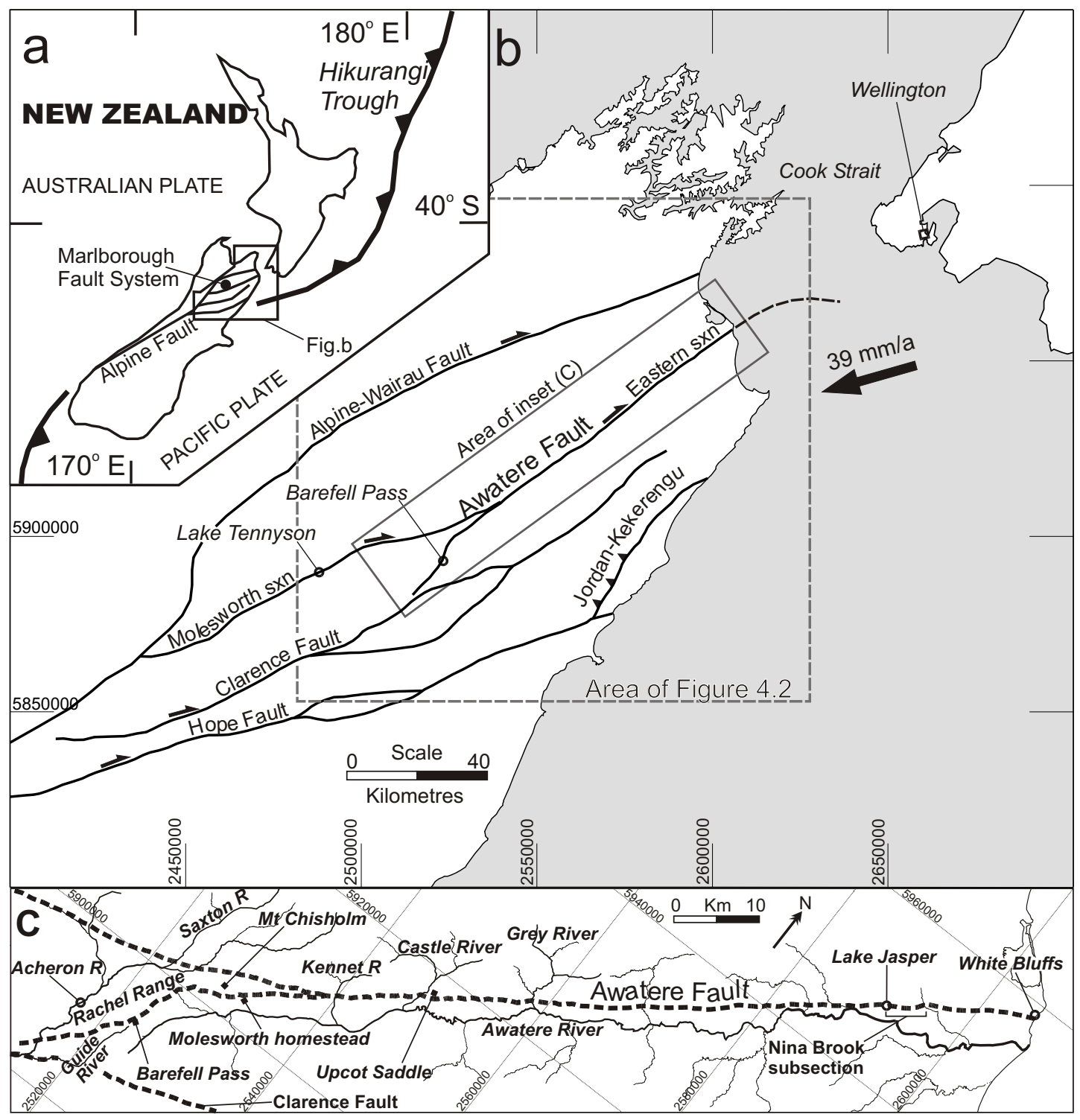

Figure 4.1a-c. (A) Map showing Pacific-Australia plate boundary through New Zealand. (B) Map of the Marlborough fault zone (northeast South Island), with principal active faults shown (Little and Roberts, 1997; Nicol and Van Dissen, 2002). The bold arrow indicates the azimuth and magnitude of Pacific plate motion relative to the Australian plate (de Mets et al., 1990; 1994); the offshore extent of the Awatere fault is adapted from Carter et al. (1988). (C) Location map of the Awatere Fault trace, with specific localities referred to in the text. 
earthquake. Of particular interest is the slip distribution in the vicinity of the previously-unmapped fault junction zone between the eastern and Molesworth sections of the fault, which may offer insights into the influence of a major faultsegment junction on rupture nucleation and propagation along a strike-slip fault. Refining the length and mean displacement over the whole surface rupture also offers the opportunity directly to calculate the moment magnitude of the earthquake, a result which can be compared to other previous magnitude estimates based on regression of geometrical rupture parameters (e.g., Wells and Coppersmith, 1994) and attenuation models of felt intensities (e.g., Dowrick and Rhoades, 1999). This chapter (1) refines the length and displacement estimates for the 1848 surface rupture by field mapping of a previously-unmapped active trace in the inland region southwest of Grey River; (2) re-evaluates the moment magnitude of the earthquake based on these new length and displacement estimates; and (3) tests the hypothesis that the Molesworth section did not rupture in 1848, with the consequent inference that the fault junction between the eastern and Molesworth sections is an important boundary between independent rupture segments, and may function as a barrier to propagation of earthquake ruptures.

\subsection{PREVIOUS WORK ON THE 1848 EARTHQUAKE}

\subsubsection{Seismicity}

The 1848 earthquake sequence did not appear to have involved any foreshocks, with the largest magnitude earthquake occurring on October 16. This mainshock caused three deaths and extensive damage to brick buildings in Wellington, and was followed by numerous aftershocks, the largest of which struck on October 17, 19 and 24. These aftershocks, while large enough to cause further building damage in Wellington, were demonstrably smaller than the October 16 mainshock, and have inferred magnitudes between M 6-7.5 (Eiby, 1980).

Until recently, the site of rupture nucleation for the 1848 event was in dispute. Based on contemporary accounts referring to surface rupture and subsidence in the "Wairau" area, Eiby (1980) concluded the 1848 earthquake sequence ruptured the Wairau Fault. Following Grapes and Wellman's (1986) observation that beach ridges $<800$ years old overlying the Wairau Fault are 
unfaulted, Grapes et al. (1998) re-examined the historical accounts, including observations by Awatere landowner Frederick Weld and geologists Sir Charles Lyell, F. von Hochstetter and Alexander McKay, which specifically refer to a recent rupture of the Awatere "line of fracture" from the coast at White Bluffs to Molesworth Station. Most importantly, a survey map of the lower Awatere Valley in 1854 by T. Musgrave explicitly refers to rupture of the Awatere Fault, though the age of this rupture was given as October 1847 (Grapes et al., 1998). These new data led to the conclusion that the 1848 earthquake sequence involved rupture of the Awatere Fault, rather than the Wairau Fault. The probable magnitude of this rupture was inferred to be 7.4-7.5 on the basis of a small number of single-event displacements, by application of Wells and Coppersmith's (1994) rupture magnitude regressions, and maximum felt intensities assigned using historical accounts (Grapes et al., 1998). Recent paleoseismic studies on the eastern section near Lake Jasper (Benson et al., 2001; Hill et al., 2001) and at Upcot Saddle (Chapter 3, this report) provide further strong evidence for a surface rupturing event on the Awatere Fault during the last $\sim 300$ cal. years B.P., as is consistent with the interpretation that this part of the fault ruptured in 1848 .

\subsubsection{Slip distribution}

As the surface slip distribution for the 1848 earthquake was not mapped immediately after the event (Grapes et al, 1998), estimates of coseismic slip at points along the rupture rely upon the preservation of metre-scale displacements of linear geomorphic features (such as ephemeral channel thalwegs, alluvial terrace risers and spur crests) that can be inferred to have accrued coseismically during the historical 1848 earthquake.

The easternmost $24 \mathrm{~km}$ of the active fault trace of the eastern section has been mapped by Grapes et al. (1998), Little et al. (1998) and Benson et al. (2001), with small horizontal offsets $(<15 \mathrm{~m})$ recorded at 27 locations. Of these, 24 are inferred to be coseismic displacements attributable to the 1848 earthquake. These range from $3.5 \pm 1$ to $7 \pm 2 \mathrm{~m}$. Little et al. (1998) also mapped a sequence of offset alluvial terraces at Grey River, and concluded that strike-slip displacement of the youngest terrace riser $(5.6 \pm 2.1 \mathrm{~m})$ occurred during the 1848 earthquake. 
McCalpin (1996a) mapped the Molesworth section from Mt Chisholm to near Lake Tennyson, measuring 14 small displacements between 6-8 $\mathrm{m}$ and examining evidence of the most recent surface rupture in a trench near Acheron River and streamcuts to the west of Isolated Flat. Dating of these exposures suggest that the youngest surface rupturing event took place between 522-597 cal. years B.P. This forms the basis for interpretations that the 1848 rupture broke only the eastern section of the fault, while it bypassed the Molesworth section, propagating southwest past the junctions region along the eastern section toward Barefell Pass (Benson et al., 2001; Grapes et al., 1998). However, results from two new paleoseismic trenches excavated across a $20 \mathrm{~m}$-wide transtensional sagpond on an aggradational terrace on the Molesworth section at Saxton River have shown the most recent rupture to have occurred between 0-440 cal. years B.P. (with the preferred age 0-310 years B.P.; see Chapter 3, this report), rather than the older age of McCalpin (1996a). As this new age brackets the 1848 event (= 102 cal. years B.P.), it raises the possibility the Molesworth section did in fact last rupture in 1848, a relationship that would have important implications for the mechanical significance of the junction between the two principal fault sections.

\subsection{ESTIMATES OF SURFACE RUPTURE LENGTH}

Estimates of the coseismic slip at points on the Awatere Fault were made using point measurements of inferred single-event displacements at all possible points along the Awatere Fault, including the section known to have ruptured in 1848. The total length of the 1848 rupture is constrained by the fault-parallel distance between the two sites of observed offset that are furthest apart. Estimating the rupture length in this way provides a minimum estimate, because of the arbitrary nature of the two end-points, as it is possible that the rupture extended beyond these sampled limits. This method also involves other implicit assumptions, which are discussed in detail below.

Coseismic displacement data for the 1848 rupture prior to this study was available for only the easternmost $24 \mathrm{~km}$ of the eastern section, with one additional more inland point measurement at Grey River. New smallest offset data collected as part of this study extends the coverage of small, potentially syn-1848 displacements on the eastern section westward from Grey River to within $500 \mathrm{~m}$ of Barefell Pass. 
This revised and enlarged coseismic slip distribution verifies that small, single-event offsets can be traced inland along the eastern section of the Awatere Fault at least as far as Barefell Pass. Figure 4.2 shows the locations of these single-event displacement sites along the eastern section from the coast to Barefell Pass. In addition, it plots the sites where small offsets have been observed on the Molesworth section between Kennet River and Saxton River. The fault-parallel length on the eastern section of the Awatere Fault between the end-points yields a minimum rupture length of $100-110 \mathrm{~km}$, depending on whether one includes poorly preserved displacements near Barefell Pass. Errors in obtaining this rupture length estimate are discussed below.

\subsubsection{Uncertainties in rupture length calculation}

The estimation of the surface rupture length relies upon the validity of two chief assumptions. First, it is assumed that all the smallest, metre-scale horizontal geomorphic displacements $(<\mathrm{c} .7 \mathrm{~m}$ for the Awatere Fault) accrued as a result of a single coseismic slip increment during the most recent surface rupture. Secondly, it is assumed that all the individual measurements record one earthquake of the same age, in this case 1848. On the eastern section of the Awatere Fault, these assumptions can be made with a fair degree of confidence, because both historical accounts and paleoseismic studies support the occurrence of a laterally continuous rupture along the eastern section between the coast and Barefell Pass in 1848 (Grapes et al., 1998; Benson et al., 2001; Hill et al., 2001; Chapter 3, this report). The second assumption becomes more tenuous if data from the Molesworth section is also included, given the possibility, advanced by McCalpin (1996a), that this part of the fault did not rupture in 1848 .

This estimate of the 1848 rupture length is a minimum because the surface rupture may have extended for some distance beyond the end-points of the coseismic displacement data (Figure 4.2). The rupture may have extended further to the northeast beyond White Bluffs and into Cook Strait, and/or further to the southwest across the steep, scree-covered flanks of the Rachel Range and Guide River catchment. In this southwestern region subtle landscape features such as small scarps are unlikely to be preserved on the active scree slopes. However, the Awatere Fault has been resolved from shallow-crust seismic studies in Cook Strait to extend $\sim 20 \mathrm{~km}$ out to sea past White Bluffs (Carter et al., 1988), and in new mapping is 


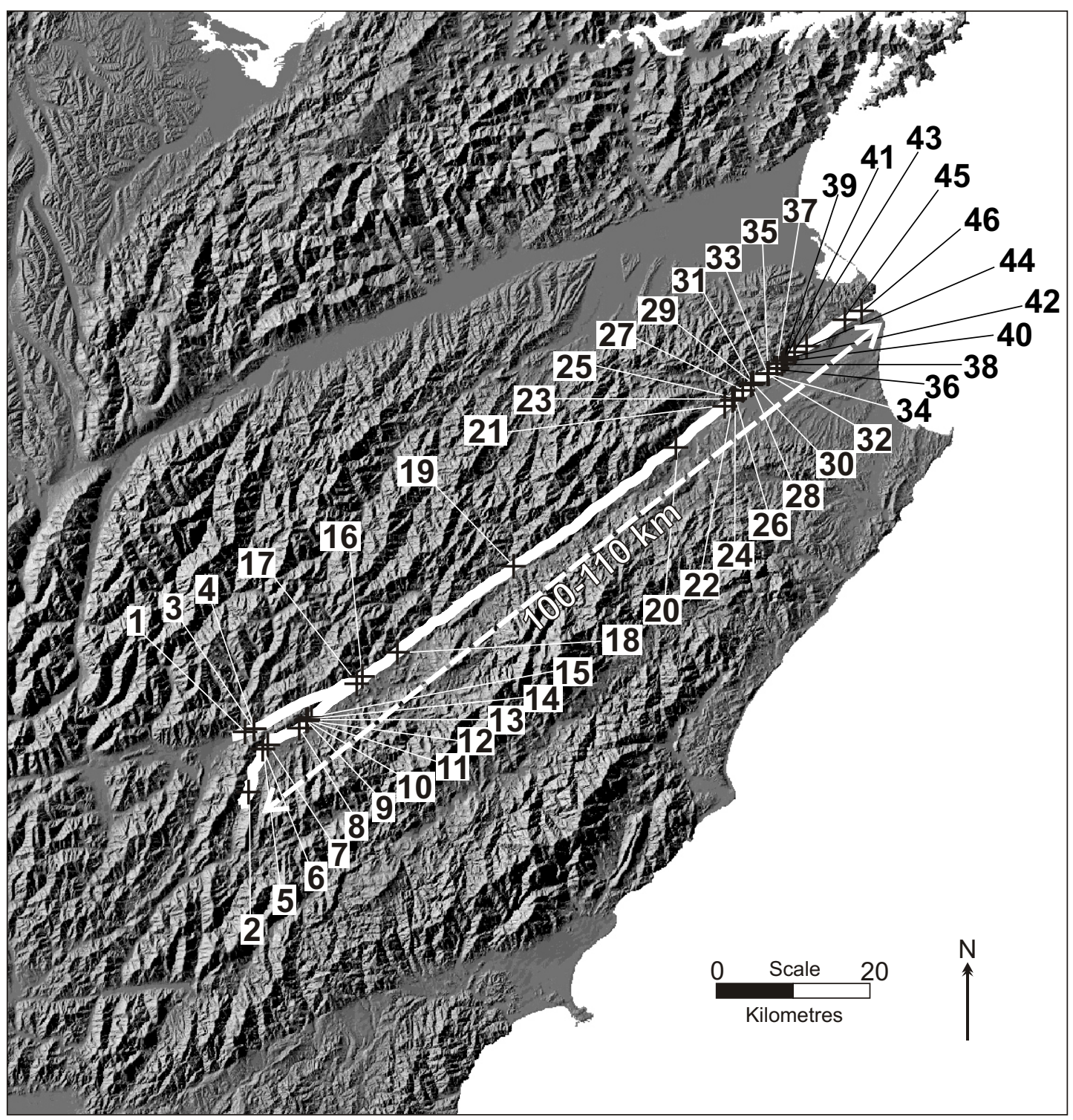

Figure 4.2 Map showing distribution of sites showing small geomorphic displacements $(<15 \mathrm{~m})$. Small offsets were recorded along the eastern section from the coast to within $500 \mathrm{~m}$ of Barefell Pass, a cumulative fault-parallel length of $\sim 110 \mathrm{~km}$, and on the Molesworth section from Kennet River to Saxton River. Refer to Table 4.1 for individual site details. 
traceable for $\sim 13 \mathrm{~km}$ southwest from Barefell Pass toward the Clarence Fault (Chapter 2). Therefore, if the 1848 surface rupture did extend beyond the limitations of the current data points, its actual length could potentially be as great as $140 \mathrm{~km}$.

Another reason why the $110 \mathrm{~km}$ estimate for the 1848 rupture length may be an underestimate is that it excludes the possibility of any contemporaneous rupture on the Molesworth section. New ${ }^{14} \mathrm{C}$ data on the age of the last Molesworth section rupture at Saxton River (Chapter 3), contrary to the inference of McCalpin (1996a), are consistent with a model of simultaneous rupture of the eastern and Molesworth sections. This possibility runs counter to previous inferences that the junction acted as a mechanical boundary between distinct earthquake rupture segments in 1848 (Grapes et al., 1998). The new hypothesis is circumstantially supported by new mapping of the junctions region, which shows the fault junction to be a much more acute and more smoothly curved transition than previously mapped (Chapter 2). If the two sections were to rupture in the same earthquake, then theoretically the rupture length could potentially be up to $\sim 250 \mathrm{~km}$, for example, if the Molesworth section ruptured as far as the Alpine Fault (Figure 4.1). A more likely increase is up to $\sim 190 \mathrm{~km}$, which represents the addition of the $\sim 50 \mathrm{~km}$ length of the well-preserved Molesworth trace (as mapped by McCalpin, 1996a) to the $140 \mathrm{~km}$ of the eastern section. The implications of adding the Molesworth section to estimates of the eastern section rupture length are discussed in more detail below.

\subsection{SURFACE DISPLACEMENTS}

\subsubsection{Magnitude and distribution of single-event offsets}

As mentioned above, calculation of the mean displacement and slip distribution along the rupture length are made using point measurements of the smallest geomorphic offsets. These are inferred to represent surface slip during the most recent event, in this case the 1848 earthquake, and fall in the range of 3-7 m.

Grapes et al. (1998), Little et al. (1998) and Benson et al. (2001) recognised 25 smallest geomorphic displacements on the eastern section between White Bluffs and Grey River, and attributed them to the 1848 earthquake. For this study, 18 new small geomorphic displacements $(<10 \mathrm{~m})$ were identified on the eastern section $(14$ sites) between Grey River and the confluence of the Guide and Acheron Rivers; and 
on the Molesworth section (4 sites) between Kennet River and Saxton River (Figure 4.1; Table 4.1). The 14 offsets $<8 \mathrm{~m}$ on the eastern section are reliably attributed to the 1848 rupture: larger displacements $(\sim 8-10 \mathrm{~m})$ are likely to represent cumulative surface displacement during the two most recent events, as is consistent with new paleoseismic results (site 1; Chapter 3). Similarly, evidence for sequential offset and abandonment of ephemeral channels at sites 3,11 and 13 (Table 4.1) suggests multiple events leading to cumulative displacement $<10 \mathrm{~m}$. The smallest offsets on the eastern section (13 sites) are assigned to the 1848 earthquake, whereas the smallest offsets on the Molesworth section ( 2 sites) are attributed to the most recent event on this part of the Awatere Fault, which may or may not have been during $1848\left({ }^{14} \mathrm{C}\right.$ age constraints for the last event at Saxton River are $0-450$ cal. years B.P., see Chapter 3).

The most common offset features in the upper Awatere Valley that preserve small horizontal displacements are beheaded or abandoned channels incised into alluvial terrace treads, though more rarely spurs and active channels were observed to be offset by 3.7-6.5 m. The majority of offsets were measured in the field by projecting the displaced feature to the fault trace along the ground surface and measuring the separation with a measuring tape. At sites 1 and 9-14, cm-precision surveys were carried out with a Real-Time Kinematic (RTK) GPS system to create detailed contour maps of the offset feature by gridding and contouring of the GPS data (see Figure 4.3). These microtopographical maps were used to project the offset feature to the fault plane by taking into account the plunge of the feature and the attitude of the fault plane (see Little et al., 1998).

In their study of the easternmost $24 \mathrm{~km}$ of the 1848 surface rupture, Benson et al. (2001) noted a local slip maximum of $<7 \pm 2 \mathrm{~m}$ on the Nina Brook subsection, a $5.5 \mathrm{~km}$-long geometric fault segment bounded by adjacent releasing and restraining bends that forms a $1 \mathrm{~km}$-wide releasing stepover in the fault trace. Outside this stepover region, smallest displacements decrease to $\sim 4 \mathrm{~m}$ to the east and west. In a small drainage catchment on the southeast flank of Mt Chisholm, the eastern section of the Awatere Fault trace cuts across alluvial terraces to define a $\sim 1 \mathrm{~km}$-long releasing side-step. Well-preserved ephemeral channels incised into alluvial terrace treads there record small offsets that range between $4.6 \pm 1.3$ and $6.2 \pm 1.7 \mathrm{~m}$ (sites 9 , 10, 12 and 14; Table 4.1). To the east and west of these sites, displaced features 


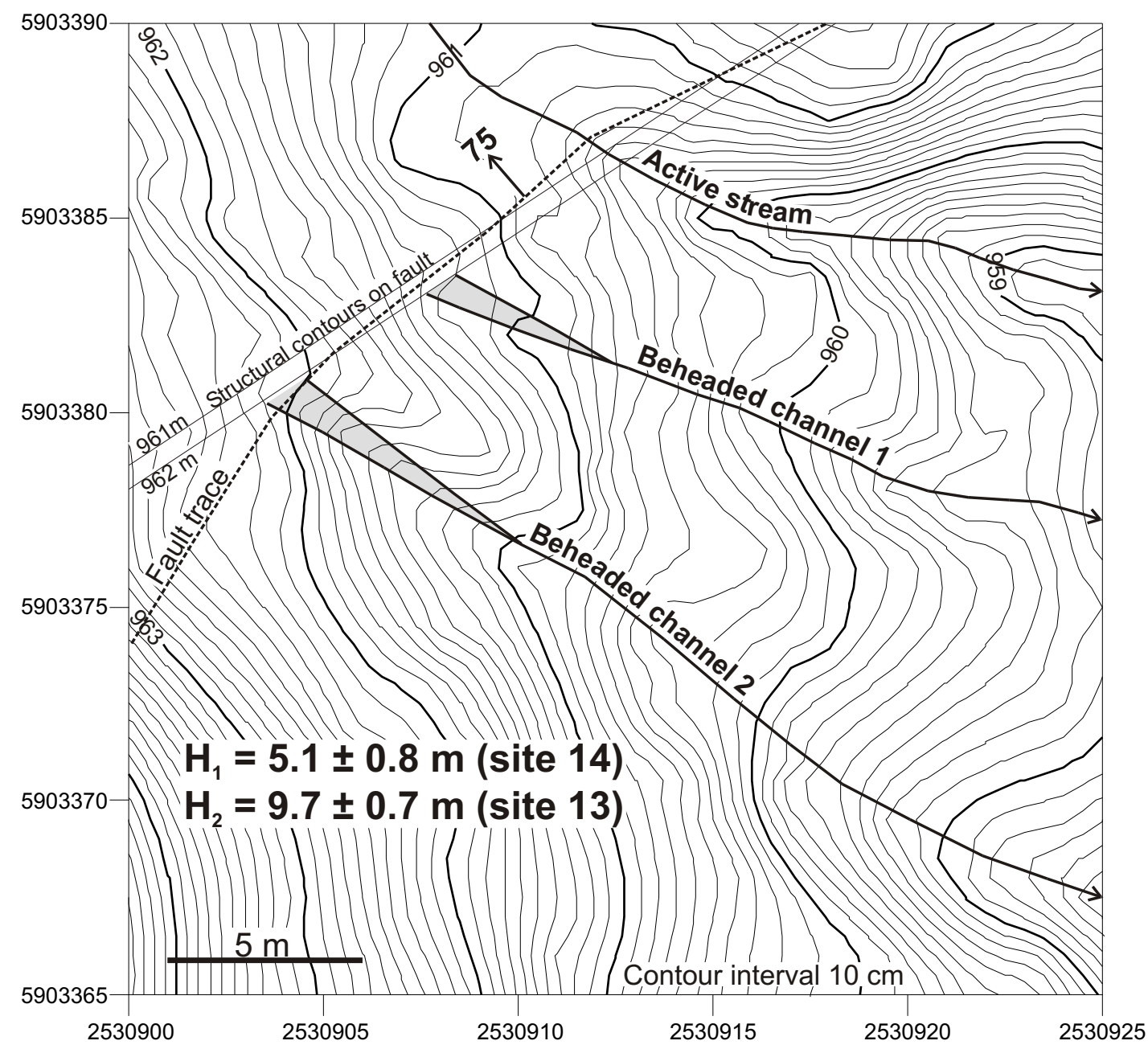

Figure 4.3 Small-scale contour map surveyed with an RTK-GPS showing two beheaded channels displaced dextrally away from the active stream (sites 13-14). These channels record sequential offset during the two most recent surface rupturing events. Up-plunge projection of the channel thalwegs to structural contours constructed on the fault plane allowed accurate measurement of horizontal offsets. 
define a variable slip distribution with individual offsets ranging from $4.1 \pm 0.5$ to 6.5 $\pm 2.5 \mathrm{~m}$. Single-event offsets on the Molesworth section, west of Kennet River, include the smallest values measured, ranging from $2.2 \pm 0.4$ to $3.7 \pm 1 \mathrm{~m}$.

$\underline{\text { Variation in slip magnitude and sense of throw }}$

Figure 4.4 plots horizontal to vertical $(\mathrm{H}: \mathrm{V})$ ratio of slip and the magnitude of horizontal slip against local fault strike. No simple pattern exists between the slip components and fault strike, although the majority of larger offset values appear to be located where the fault trace has a more easterly strike (e.g. the Nina Brook subsection). Benson et al. (2001) proposed that in these areas of maximum local slip there was possibly enhanced moment release during rupture propagation due to the transtensional geometry of the fault. Another possible explanation for the variation is the contribution of slip acquired during high-magnitude aftershocks. The aftershock sequence, while augmenting damage sustained to buildings in Wellington during the October 16 mainshock, only involved 3 relatively large magnitude shocks. Provisional magnitude estimates of 6-7.5 have been assigned to these aftershocks, with the lower end of this range likely to be more accurate (Eiby, 1980). It is therefore assumed that most or all of the coseismic slip accrued during the October 16 mainshock.

Postseismic surface creep is another possible source of the variable slip distribution. Langridge et al. (2002), in their study of the slip distribution on the Sakarya fault segment during the 1999 Izmit earthquake, inferred that at sites of maximum local slip all of the slip was released during or soon after the mainshock, and that 'afterslip' only occurred in significant amounts at sites distant from the local slip maxima. However, as such afterslip is hard to quantify following modern earthquakes, it is essentially impossible to calculate for an historical event such as 1848 .

Vertical slip is typically an order of magnitude smaller than the horizontal slip component. As relatively few vertical offsets were measurable with respect to the smallest geomorphic displacements, however, and given the small vertical slip magnitudes, consideration of this slip component does not significantly increase the mean three-dimensional coseismic slip estimate for 1848. Anomalous to this trend, 

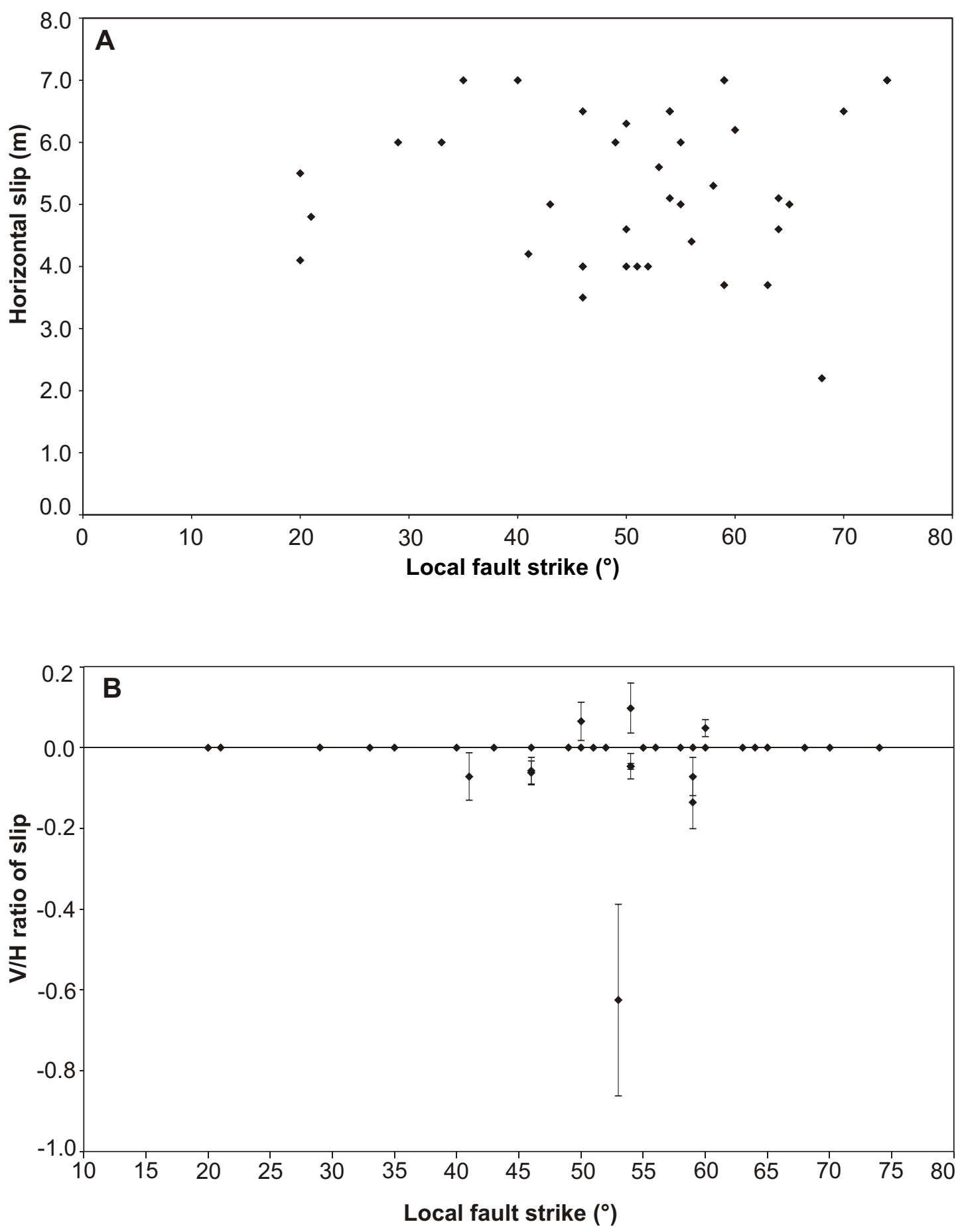

Figure 4.4a-b. (A) Graph of horizontal slip against local fault strike for the complete set of smallest geomorphic offsets $(n=39)$. The data indicate little relationship between slip magnitude and the local fault strike. (B) Graph of vertical to horizontal displacement ratios for offset geomorphic features on the Awatere Fault. Anegative V/H value indicates vertical displacement sense is upthrown to the southeast. 
the offset terrace riser at Grey River shows a large vertical displacement (3.5 $\pm 0.2 \mathrm{~m})$ in relation to a horizontal offset of $5.6 \pm 2.1 \mathrm{~m}(\mathrm{H}: \mathrm{V}=2.3-1.0)$. This large vertical displacement may reflect local site effects due to incision by Grey River, which created an enhanced component of vertical slip on a locally re-oriented fault trace (e.g., Benson and Little, 2001). Another possibility is that this offset has accrued during more than one earthquake; Knuepfer (1992) assigned a pebble weathering rind-based age of $2380 \pm 820$ years B.P. to this terrace surface, which is older than the ages of both the 1848 and the penultimate events on the eastern section (Benson et al., 2001; Hill et al., 2001; Chapter 3, this report). While this would suggest this terrace records displacement of at least the last two events, the uncertainties involved in pebble weathering rind calibrations (e.g., Chapter 5) do not rule out this offset solely representing the 1848 event.

\subsubsection{Uncertainties in displacement measurement}

Most of the uncertainties surrounding measuring geomorphic displacements are hard to quantify, but it is important to acknowledge them as they may bias the results and interpretations. As mentioned above, estimates of the length and surface displacement for the 1848 rupture rely upon the validity of two main assumptions: that small displacements represent only one surface rupture, and that all such displacements are of uniform age along the fault. Given the dataset of historical observations and paleoseismic data around Lake Jasper that confirms extensive surface rupturing in 1848 along the Awatere Fault, these assumptions can be made for the entire length of the eastern section of the fault with a high degree of confidence. Therefore the most apparent source of uncertainty for the individual displacements is the technique used for measuring the displacements. As already stated, using a compass and tape measure in the field relies upon projections of channel thalwegs and ridge crests to the fault along the ground surface. Accordingly, this method does not take into account the dip of the fault or the plunge of the feature. Surveying offset features with an RTK-GPS at sites 1 and 9-14, and the subsequent construction of microtopographical maps of the features, on the other hand, does allow three-dimensional calculation of more precise slip estimates (with errors of $\pm 5-15 \%$ ), but this was not practical at all sites. Most offsets (11 sites) were

measured with a tape measure, and these typically have uncertainties attached to them of up to $\pm 45 \%$ (average relative error was $\pm 15-30 \%$ ). These tape measure 
errors are quoted as symmetrical values about a 'mean' offset amount, and are based on a qualitative estimate of the uncertainty in landform projection to the fault plane. These are treated as nominal estimates of the $95 \%$ confidence interval.

An important source of uncertainty in the slip estimates are the inclusion of especially poorly preserved or modified offset features such as active channels. Well-preserved stream channels on alluvial terraces are associated with the least uncertainty; the paleo-displacement of still-active channels on steep hill country, however, cannot be measured with certainty as some deflection across the fault could be due to non-tectonic curvature of the incising channel. The most prominent examples of this are sites 2, 7 and 17 (Table 4.1; Figure 4.2). At site 2 a stream eroding through scree and vegetated colluvium into greywacke bedrock has been apparently offset $4.8 \pm 1.2 \mathrm{~m}$. However, it is possible that some deflection of the channel was due to infilling by a colluvial fan, forcing a shift in location of the stream channel that was unrelated to any coseismic offset.

As there are only three of these less certain single-event slip estimates, their inclusion or exclusion in the dataset would not significantly change the estimate of the mean slip. The southwestern extent of surface rupture is defined by the deflected active channel at Barefell Pass mentioned above. Excluding this site would decrease the minimum estimate of the 1848 rupture length from $110 \mathrm{~km}$ to $\sim 100 \mathrm{~km}$ (see site 5, Table 4.1). However, as historical accounts record evidence of rupture to at least as far as Barefell Pass (Grapes et al., 1998), it is reasonable to conclude that the deflection of the channel near Barefell Pass does represent coseismic displacement during the 1848 earthquake.

\subsubsection{Second-smallest offsets}

At three locations in this study (sites $3,11,13$ ) and three locations along the easternmost part of the eastern section (sites 28, 29, 42; Benson et al., 2001) abandoned or beheaded channels show evidence for their repeated displacement. This is shown by the preservation of two or more channels, beheaded at the fault scarp, that are dextrally displaced away from the active channel (Figure 4.3). At these sites the amount of coseismic slip that accrued during both the penultimate and most recent events can be estimated by measuring the incremental separation of each beheaded channel relative to the still-active modern channel. On the eastern section, 
the penultimate event can be constrained by ${ }^{14} \mathrm{C}$ dating to have taken place $980-1180$ cal. years B.P. (see chapter 3, this report). Despite this long interval of time, the separation between the two beheaded channels should be a good proxy for the amount of displacement during the penultimate event. These second-smallest offsets are approximately double the size of the smallest displacements in the same area, implying the penultimate event had a similar magnitude of surface displacement to 1848. For example, sites 11 and 13 show offsets that are approximately twice as large as those at sites 12 and 14 (see Table 4.1).

A small number of active streams were also observed to show deflections of between 8-12 m. While offsets of this magnitude would suggest they have accrued during only the two most recent events, the fact that the offset feature is a perennially active stream implies that these offsets are likely to be minima, because of the possibility that they have been laterally trimmed by the stream. Accordingly they are not included into the compilation of second-smallest offsets. Similarly, offset of a channel incised into the Saxton-6 terrace on the Molesworth section (see Chapter 5) was not included into the single-event dataset. As the age of the terrace surface (1.172 $\pm 0.111 \mathrm{ka}$ B.P.; McCalpin, 1996a) is older than at least the two most recent surface ruptures on this part of the fault (see Chapter 3), the displacement of $6.3 \pm 0.8$ $\mathrm{m}$ is inferred to represent slip that has accumulated during two surface ruptures.

\subsection{DISCUSSION: DISPLACEMENT-LENGTH SCALING RELATIONSHIPS}

\subsubsection{Length-averaged mean displacement}

In order to evaluate the slip distribution during 1848, slip at each site was plotted against that site's position along the fault trace. This is shown in Figure 4.5, with the coast at White Bluffs taken as an arbitrary origin for the fault length. Although it is probable that the 1848 surface rupture extended beyond Barefell Pass, the offset at Barefell Pass is taken as $0 \mathrm{~m}$ because of the lack of observable scarps on the steep, scree-covered flanks of the Rachel Range to the southwest. Similarly, slip offshore from White Bluffs is assumed to be $0 \mathrm{~m}$, as both the length and magnitude of displacement of the submarine surface rupture is unknown and cannot be confidently estimated. 
On the eastern section, there are only 2 single-displacement slip measurements between 24 and $80 \mathrm{~km}$ from White Bluffs (sites 19 and 20); both were observed by Little et al. (1998). Given the paucity of data in this $56 \mathrm{~km}$ long interval, and the abundance of offsets in the surrounding regions, the data was subdivided into three regions: the coastal region containing Grapes et al.'s (1998), Little et al.'s (1998) and Benson et al.'s (2001) data (23 points), the central region with its 2 offsets, and the inland region, containing the 11 single-displacement sites recognised on the eastern section as part of this study. A mean slip value was calculated for each region separately to determine whether or not the absence of data from the central region would significantly influence the calculation that integrated slip along the entire fault. All three regions have a mean displacement between 5.1$5.3 \mathrm{~m}$, and the length-averaged mean slip for the entire eastern section, including the central region, is here calculated to have been $5.3 \pm 1.6 \mathrm{~m}$. This is an increase in the mean coseismic slip value of $0.4 \mathrm{~m}$ from Benson et al.'s (2001) estimate of $4.9 \mathrm{~m}$, which was a numerical mean averaged over only $24 \mathrm{~km}$ of fault length. The uncertainty for the new mean slip incorporates the error for each individual point measurement.

As historical and paleoseismic data indicates that the 1848 rupture bypassed the Molesworth section, less emphasis was given to mapping small geomorphic displacements on the Molesworth section, which cannot be confidently attributed to that event. Therefore, the Molesworth section was only examined in detail between Kennet River and Saxton River, along which four sites yielded small offset data. Two of these are attributed to the most recent rupture along this section of the Awatere Fault (sites 4 and 16). Figure 4.5 shows these offsets, which occur along the portion of the Molesworth section that overlaps with the adjacent eastern section. Calculating a length-averaged mean displacement using these two measurements would not be statistically reasonable, as the total length is unknown and there are so few data; important parameters such as moment magnitude and slip distribution therefore cannot be ascertained for the Molesworth section with any confidence. McCalpin (1996a) noted 12 offsets of $<8$ m magnitude to the west of Saxton River, and inferred a typical event magnitude of $\mathrm{M}_{\mathrm{w}}$ 7.5-7.8 for the last event on the Molesworth section which he extended $\sim 50 \mathrm{~km}$ west of the junctions region to near Lake Tennyson. 


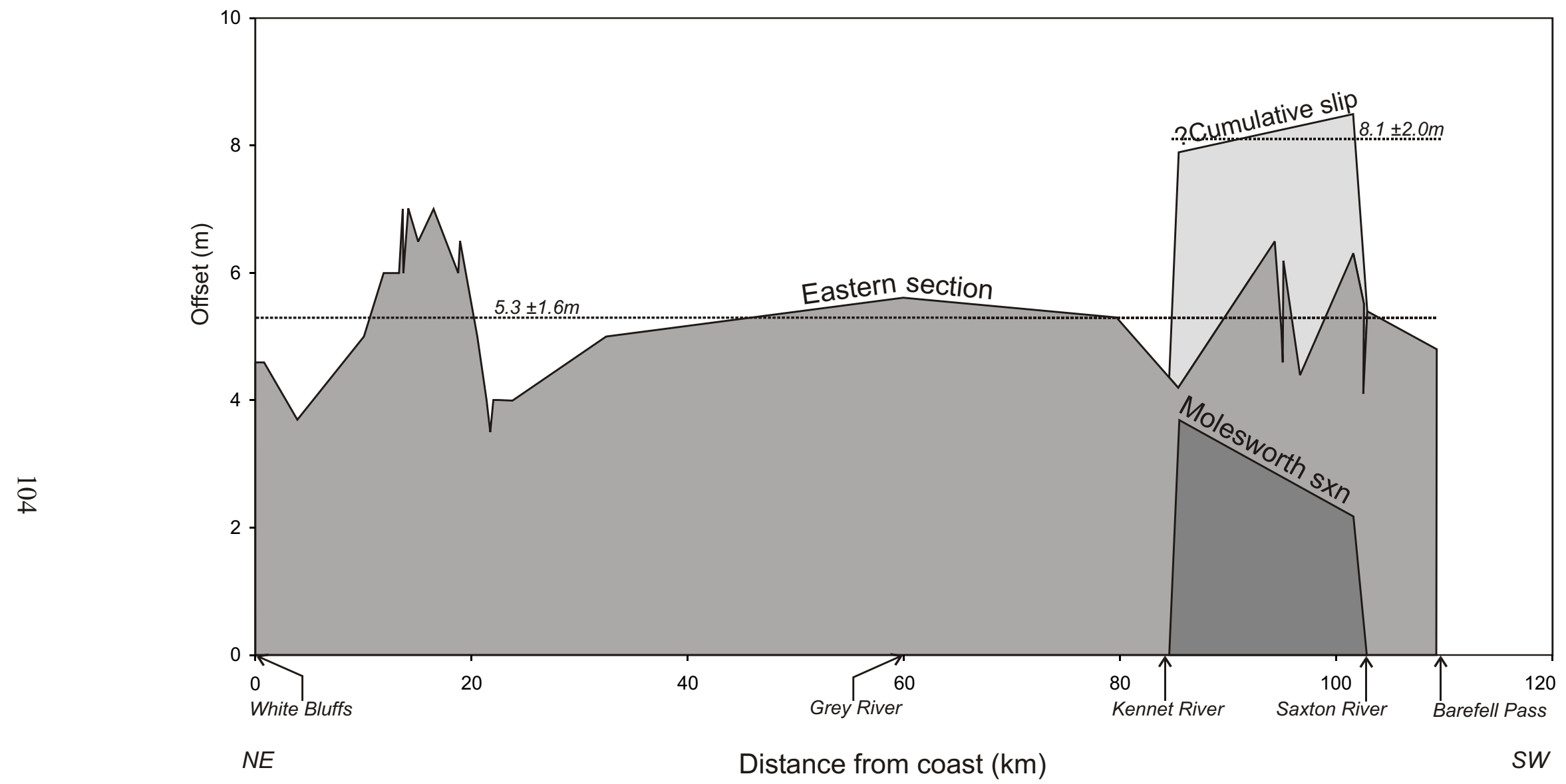

Figure 4.5 Graphical compilation of smallest horizontal offsets measured on the Awatere Fault between the coast at White Bluffs (origin) and Barefell Pass. The length-averaged mean of the eastern section data indicates the 1848 earthquake was associated with $5.3 \pm 1.6 \mathrm{~m}$ of mean surface strike-slip displacement over the $110 \mathrm{~km}$ from the coast to Barefell Pass. If one attributes small geomorphic displacements on the Molesworth section to the 1848 event as well, then the cumulative-slip maximum for that earthquake would have occurred in the area of fault section overlap to the southwest of Kennet River. 


\subsubsection{Slip distribution}

On the eastern section, between Kennet River and Barefell Pass, the slip distribution is complex, varying between 4.6-6.5 m over less than $1 \mathrm{~km}$ of fault length (see Figure 4.5). In this region there is good evidence for significant and variable off-fault deformation, a situation which has probably contributed to the complex pattern of fault slip at the surface. The off-fault deformation is expressed by numerous well-preserved scarps that transect the 'Mt Chisholm block' in the fault junctions region (see Figure 4.6). Unfortunately, the cumulative magnitude of slip accommodated by this distributed deformation is unquantified due to the lack of suitable displaced landforms. Despite this, the excellent preservation of these scarps suggests a similar age of formation as the scarps on the main Awatere Fault trace, and implies that considerable distributed deformation may have affected the $\mathrm{Mt}$ Chisholm block during 1848, possibly when the propagating dynamic rupture front encountered the fault junctions region. While Figure 4.5 shows local variations in slip on wavelengths as short as $1 \mathrm{~km}$, on the scale of the entire eastern section no slip maximum is apparent. At face value, the lack of evidence for a significant decrease in single event slip along the recognised trace of the 1848 rupture is consistent with the idea that the actual rupture length extended beyond the nominally recognised limits of $\sim 110 \mathrm{~km}$.

\subsubsection{Implications for incorporation of Molesworth section displacement}

Recent paleoseismic studies on the Molesworth section west of Lake Tennyson (Langridge, 2000) and at Saxton River (Chapter 3) show strong evidence that the most recent surface rupture on the Molesworth section may have been coeval with the 1848 event on the eastern section. The age of the most recent surface rupture on the Molesworth section has been constrained at Saxton River to 0-310 cal. years B.P. (Chapter 3). McCalpin's (1996a) age of 522-597 years B.P. for the last event on the Molesworth section was derived from data to the west of Saxton River, in the vicinity of Lake Tennyson, and does not agree with this new data that was obtained further to the east. Taken together, these data suggest the possibility of an historical rupture/-s of the Molesworth section between Kennet River (the eastern boundary of the Molesworth section) and at least as far west as Saxton River, a distance of $\sim 20 \mathrm{~km}$. 


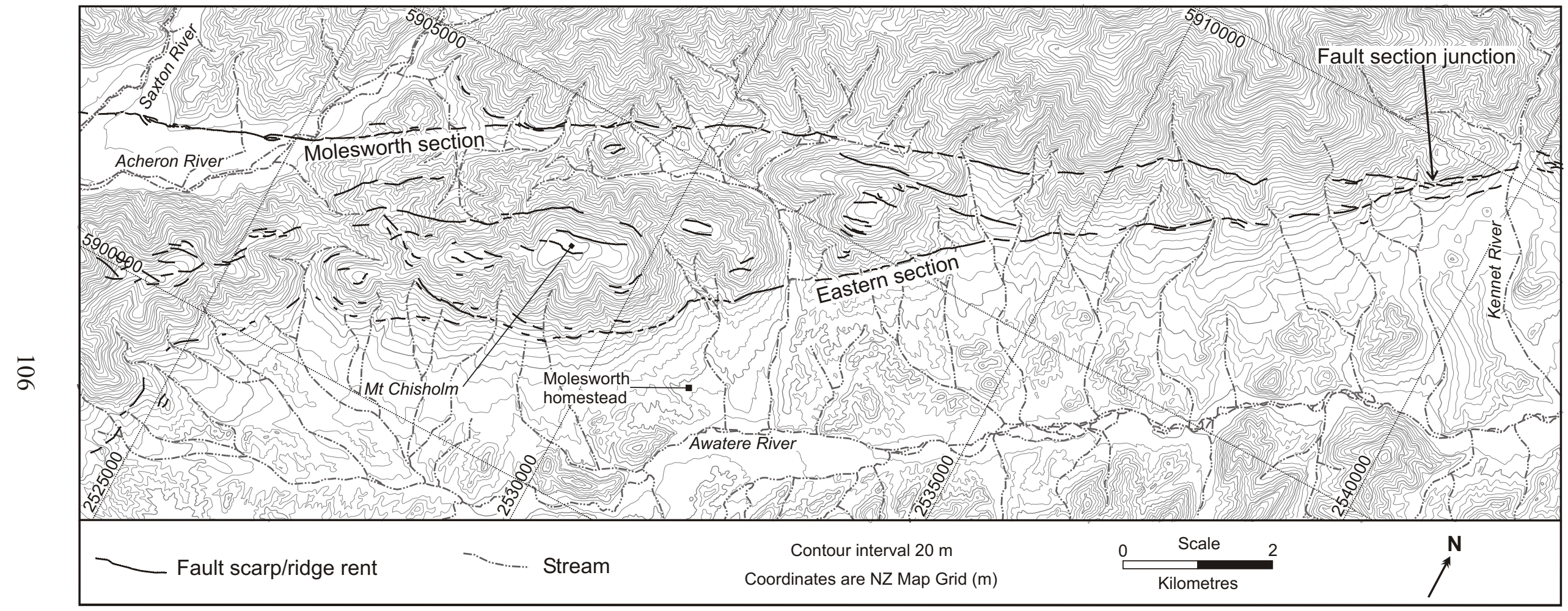

Figure 4.6 Scarp map of the Mt Chisholm block. The abundance of continuous, well-preserved scarps throughout the zone between the two principal fault sections suggests distributed surface deformation resulting from a relatively recent earthquake. 
New ${ }^{14} \mathrm{C}$ ages suggest approximately contemporaneous rupture with respect to a large event that took place at $\sim 1$ ka both on the Molesworth section (930-1070 cal. years B.P.) and on the eastern section (980-1180 cal. years B.P.; see Chapter 3). Thus it is possible that the 1848 earthquake ruptured both fault sections simultaneously, a relationship that leaves open the possibility that large events can rupture across this apparent "segment boundary" (c.f. Rubin, 1996). As the resolution of available paleoseismic dating techniques cannot distinguish between a simultaneous, large rupture of two fault sections and two separate, triggered ruptures that are closely spaced in time (McCalpin, 1996c), it is equally likely that the close correlation of events represents individual earthquakes occurring within a geologically short period. Such a model has been proposed for a sequence of seven earthquakes in the Marlborough fault system since the 1848 event (Doser and Robinson, 2002) and a sequence of ten earthquakes on the North Anatolian Fault between 1939-1992 (Stein et al., 1997).

As mentioned above, the slip distribution of the eastern section does not appear to show any obvious decrease along-strike away from a slip maximum; instead there is relatively uniform slip from the coast to at least as far as Barefell Pass. This relationship suggests that the Mt Chisholm block may not have been close to the rupture end-point in 1848. Similarly, the individual offsets on the Molesworth section to the west of the fault junction, while sparse, also do not record an obvious decrease in slip eastward. Given the inference that triggered events nucleate near the end-points of the preceding rupture (e.g., Stein, 1999), one possible interpretation is that the 1848 earthquake ruptured both the eastern and Molesworth section simultaneously. While not categorical evidence for such an hypothesis, new mapping of the fault junctions region (Chapter 2) and new paleoseismic records on both fault sections (Chapter 3) provide data that are consistent with this idea with respect to 1848 .

Should such a linkage between the eastern and Molesworth sections have existed both in 1848 and at $\sim 1 \mathrm{ka}$, the small displacements along the Molesworth section would be attributable to the 1848 rupture. The effect of their inclusion in the 1848 data set would be to increase the mean and cumulative displacement related to that earthquake. The mean (length-averaged) displacement on the eastern section 
alone is $5.3 \pm 1.6 \mathrm{~m}$; addition of the Molesworth section's single-event displacements to the 1848 dataset would increase this to $5.8 \pm 2.0 \mathrm{~m}$, not a significant increase given the other uncertainties. The most important implication of combining the single event offsets on the two sections, however, is that the true coseismic displacement southwest between Kennet River and Saxton River would be the sum of both sections' individual displacement profiles. A cumulative slip maximum of $8.1 \pm 2.0$ $\mathrm{m}$ would be obtained for the 1848 earthquake, as localised in the fault junctions region. Although this hypothesis cannot be tested, the data permit a model which suggests that the 1848 earthquake nucleated in the fault junctions region. This scenario implies that the two fault sections are mechanically linked across a recurrently broken asperity, and that the fault junction area may act as a preferred site for the nucleation of large earthquakes, accordant with current ideas about the possible mechanical role of stepovers, bends, asperities and barriers in the dynamic earthquake faulting process (e.g., Aki, 1984; King and Nabelek, 1985; Sibson, 1986; Lettis et al., 2002).

\subsubsection{Revision of moment magnitude for the 1848 earthquake}

New rupture length and surface displacement estimates for the 1848 earthquake allow re-calculation of the moment magnitude of that event. Given the refined values of $\mathrm{L}=100-110 \mathrm{~km}$ and $\mathrm{D}=5.3 \pm 1.6 \mathrm{~m}$, and assuming a rupture width, $\mathrm{W}=12-15 \mathrm{~km}$, and shear modulus, $\mu=3.0 \times 10^{10} \mathrm{~N} / \mathrm{m}^{2}$, the seismic moment can be calculated as follows (Hanks and Bakun, 2002):

$$
\mathrm{M}_{\mathrm{o}}=\mu \mathrm{WLD}
$$

Equation 4.1 yields $\mathrm{M}_{\mathrm{o}}=1.3-3.4 \times 10^{20} \mathrm{~N} \mathrm{~m}$. The corresponding moment magnitude of the earthquake can be calculated using the moment magnitude scale of Hanks and Kananmori (1979) as follows:

$$
\mathrm{M}_{\mathrm{w}}=2 / 3 \log \mathrm{M}_{0}-6.03
$$

Equation 4.2 yields a magnitude of $\mathrm{M}_{\mathrm{w}}=7.4-7.7$ for the 1848 event, which compares favourably to the previous estimate of $7.5 \pm 0.3$ for that earthquake based on attenuation of Modified Mercalli isoseismals assigned using historical accounts of shaking intensity and building damage (Grapes et al., 1998). 
New attenuation relationships developed by Dowrick and Rhoades (1999) were used to re-evaluate Grapes et al.'s (1998) felt intensity data. This revised analysis increases the estimated magnitude to $\mathrm{M}_{\mathrm{w}} 7.8$ (Dowrick, submitted). Although this new magnitude estimate seems large, the historical data on shaking intensity is sparse in the inland Marlborough region surrounding the surface rupture through Molesworth station, and thus Dowrick's re-evaluation cannot be discredited. Such an earthquake magnitude for 1848 would seem to require an increase in the rupture dimensions: for example, the rupture width would have to increase to $\sim 20 \mathrm{~km}$ as the rupture length increases to $\sim 140 \mathrm{~km}$, encompassing the entire eastern section from Cook Strait to the Clarence Fault. The available data does not preclude these possibilities: the $1966 \mathrm{M}_{\mathrm{w}} 5.8$ Seddon earthquake, for example, occurred near the northeastern (offshore) limit of the Awatere Fault, and had a centroid depth of $19 \mathrm{~km}$ (Anderson et al., 1993). The rupture length in this study was defined by the somewhat arbitrary (and underestimating) extremities of the sampled coseismic displacements. In addition, if the Molesworth section also ruptured during the 1848 earthquake, as appears plausible, then the moment magnitude could have been larger than previously estimated, in accordance with Dowrick's magnitude estimate of $\mathrm{M}_{\mathrm{w}}$ $=7.8$. Further study is therefore required on the Molesworth section to constrain the timing and extent of the most recent rupture west of Saxton River, and especially to constrain the idea that it may have taken place in 1848 .

To conduct a "sensitivity" test of differing fault parameters' empirical scaling relationships with earthquake magnitude, multiple calculations were attempted using the range of published regressions scaling rupture dimensions against moment magnitude (e.g., Bonilla et al., 1982; Wells and Coppersmith, 1994; see Table 4.2). Using the revised coseismic rupture parameters cited in this paper, these differing regressions yield 1848 magnitudes that range between $\sim 7.3$ to $\sim 8.0$, although most yield magnitudes of 7.4-7.7. It appears that the regressions based on the maximum and average displacement return magnitude estimates that are larger, whereas regressions on the rupture length yield smaller magnitudes. This appears to reinforce the notion that the known 1848 rupture length may be too small, due to the lack of any reliable estimate for the total rupture length. 
Table 4.2 - Magnitude estimates for the 1848 event using published magnitude-dimension regressions, based on revised rupture dimensions $\mathrm{L}_{\text {surf }}=110 \mathrm{~km}$ and $\mathrm{D}_{\text {avg }}=5.3 \pm 1.6 \mathrm{~m}$ (eastern section; this study)

\begin{tabular}{|c|c|c|c|c|}
\hline Source & Regression & $a\left(s_{a}\right)$ & b $\left(s_{b}\right)$ & Magnitude \\
\hline Bonilla et al. (1984) & $\begin{array}{l}M_{s}=a+b \log \left(L_{\text {surf }}\right) \\
M_{s}=a+b \log \left(D_{\text {max }}\right)\end{array}$ & $\begin{array}{l}6.04(0.215) \\
6.95(0.077)\end{array}$ & $\begin{array}{l}0.708(0.122) \\
0.723(0.146)\end{array}$ & $\begin{array}{l}7.49 \pm 0.47 \\
7.56 \pm 0.20\end{array}$ \\
\hline Wells \& Coppersmith (1994) & $\begin{array}{l}M=a+b \log \left(L_{\text {surf }}\right) \\
M=a+b \log \left(L_{\text {sub }}\right)^{1} \\
M=a+b \log \left(D_{\text {max }}\right) \\
M=a+b \log \left(D_{\text {avg }}\right)\end{array}$ & $\begin{array}{l}5.16(0.13) \\
4.33(0.06) \\
6.81(0.05) \\
7.04(0.05)\end{array}$ & $\begin{array}{l}1.12(0.08) \\
1.49(0.05) \\
0.78(0.06) \\
0.89(0.09)\end{array}$ & $\begin{array}{l}7.45 \pm 0.30 \\
7.56 \pm 0.17 \\
7.47 \pm 0.10 \\
7.68 \pm 0.12\end{array}$ \\
\hline Anderson et al. (1996) & $M_{w}=a+b \log \left(L_{\text {surf }}\right)-c \log S^{2}$ & $5.12(0.12)$ & $1.16(0.07)$ & $7.34 \pm 0.29$ \\
\hline $\begin{array}{l}\text { Hemphill-Haley and Weldon } \\
\text { (1999) }\end{array}$ & $\mathrm{M}_{\mathrm{w}}=\mathrm{a}+\mathrm{b} \log \left(\mathrm{D}_{\text {avg }} \cdot \mathrm{mvcds}\right)^{3}$ & 6.93 & 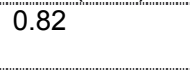 & $\begin{array}{l}7.53+0.12 \\
-0.19\end{array}$ \\
\hline Stirling et al. (2002b) & $\begin{array}{l}M_{w}=a+b \log \left(L_{\text {surf }}\right)^{4} \\
M_{w}=a+b \log \left(L_{\text {surf }}\right)^{5}\end{array}$ & $\begin{array}{l}5.45(0.08) \\
5.89(0.11)\end{array}$ & $\begin{array}{l}0.95(0.06) \\
0.79(0.06)\end{array}$ & $\begin{array}{l}7.39 \pm 0.20 \\
7.50 \pm 0.24\end{array}$ \\
\hline $\begin{array}{l}\text { Dowrick and Rhoades (in } \\
\text { press) }\end{array}$ & $\begin{array}{l}M_{w}=a+b \log \left(L_{\text {sub }}\right) \\
M_{w}=a+b \log \left(D_{\text {avg }}\right) \\
M_{w}=a+b \log \left(D_{\text {avg }}\right)\end{array}$ & $\begin{array}{l}4.75(0.14) \\
6.05(0.05) \\
6.17(0.08)\end{array}$ & $\begin{array}{l}1.50(0.09) \\
2.0(\text { con })^{6} \\
1.73(0.14)\end{array}$ & $\begin{array}{l}7.50 \pm 0.05 \\
7.42 \pm 0.18\end{array}$ \\
\hline \multicolumn{5}{|l|}{ Notes: } \\
\hline \multicolumn{5}{|c|}{$\mathrm{s}_{\mathrm{a}}=$ standard error of $\mathrm{a} ; \mathrm{s}_{\mathrm{b}}=$ standard error of $\mathrm{b} ; \mathrm{L}_{\text {surf }}=$ surface rupture length $(110 \mathrm{~km}) ; \mathrm{L}_{\text {sub }}=$ subsurface rupture length $(146.7$} \\
\hline \multicolumn{5}{|c|}{$\mathrm{km}) ; \mathrm{D}_{\max }=$ maximum surface displacement $\left(7.0 \pm 2.0 \mathrm{~m}\right.$; Benson et al., 2001); $\mathrm{D}_{\text {avg }}=$ average surface displacement $(5.3 \pm 1.6$} \\
\hline \multicolumn{5}{|c|}{ m); $\mathrm{S}=$ fault slip rate $(5.5-6 \mathrm{~mm} / \mathrm{a}$; Benson et al., 2001; Chapter 5, this report) } \\
\hline \multicolumn{5}{|c|}{ 'subsurface rupture length estimated using Wells and Coppersmith's (1994) observation that $\mathrm{L}_{\text {surf }}=3 / 4\left(\mathrm{~L}_{\text {sub }}\right)$} \\
\hline \multicolumn{5}{|c|}{${ }^{2} \mathrm{c}=0.2 \pm 0.07$} \\
\hline \multicolumn{5}{|c|}{${ }^{3}$ mvcds $=$ mode value combined displacement statistic $(\operatorname{mvcds}=1.02[+0.40,-0.43]$ for $n>10$ displacement measurements over } \\
\hline \multicolumn{5}{|c|}{$100 \%$ of the fault length) } \\
\hline \multicolumn{5}{|c|}{${ }^{4}$ regression on data from 'instrumental era' } \\
\hline \multicolumn{5}{|c|}{${ }^{5}$ regression on data from 'pre-instrumental era' } \\
\hline${ }^{6}$ constrained slope coefficient $\mathrm{o}$ & gression line & & & \\
\hline
\end{tabular}

\subsubsection{Characteristics of the penultimate event}

The preservation of sites that show sequential abandonment and displacement of stream channels allows comparisons to be drawn between the 1848 and penultimate events. As these second-smallest displacements are approximately double the size of the smaller displacements they are next to, it suggests the penultimate event was associated with similar surface displacement to the 1848 event. The fault-parallel length between sites 11 and 41 is $\sim 80 \mathrm{~km}$, potentially a minimum estimate for the surface rupture length of the penultimate event. On the basis of the similar magnitudes of coseismic displacement, the penultimate event may have had a similar moment magnitude to the 1848 earthquake. As an approximate contemporaneity exists between the eastern and Molesworth sections for the penultimate events, as is the case for the 1848 event, the penultimate event on the eastern section could conceivably have involved simultaneous rupturing of both sections of the Awatere Fault. 


\subsection{CONCLUSIONS}

The fault-parallel length of the smallest preserved geomorphic displacements indicates the 1848 earthquake on the Awatere Fault ruptured at least 100-110 km of its eastern section's surface trace, as is consistent with historical evidence. Integrating point measurements of coseismic displacement along this rupture length yields a mean displacement of $5.3 \pm 1.6 \mathrm{~m}$ for the eastern section in 1848. This is based on the assumptions that (1) any smallest, metre-scale geomorphic displacement accrued on the eastern section as a result of a single coseismic slip increment during the most recent surface rupture, and (2) all these individual slip measurements record one earthquake of the same age (=1848). Available paleoseismic data constrain the timing of the last surface ruptures on both the eastern and Molesworth sections of the Awatere Fault, together with the lack of an apparent decrease in single-event slip toward the fault junctions region where the two sections overlap, suggesting the eastern and Molesworth sections may have ruptured simultaneously in 1848, producing a local cumulative-slip maximum of $8.1 \pm 2.0 \mathrm{~m}$ in the vicinity of the fault junctions region. If true, this scenario would enlarge the mean coseismic slip estimate to $5.8 \pm 2.0 \mathrm{~m}$ during 1848 , and extend the surface area of rupture westward along the Molesworth section at least as far as Saxton River, which would not affect the estimated rupture length. Alternatively, these data may be interpreted as representing separate, triggered earthquakes over a geologically short period beyond the resolution of ${ }^{14} \mathrm{C}$ dating.

The refined rupture parameters for the 1848 event yield a new moment magnitude estimate of $\mathrm{M}_{\mathrm{w}}=7.4-7.7$ for that earthquake, which compares favourably to previous estimates based on felt intensities assigned using historical accounts. The minimum nature of the available rupture length estimate implies this magnitude is also a minimum.

Detailed mapping of fresh-looking fault scarps in the area surrounding the fault junction suggests considerable distributed off-fault surface deformation was accommodated in the region between the principal fault sections, possibly during 1848. If a cumulative-slip maximum did occur near the fault junctions region, then this suggests that the rupture nucleated near that fault section, and that this 
geometrical complexity has acted as a preferred site for the nucleation of very large $\left(\mathrm{M}_{\mathrm{w}}>7.5\right)$ earthquakes.

New mapping of the previously-unmapped eastern section fault trace southwest of Grey River also allowed the recognition of older single-event displacements that suggest that the penultimate event on the eastern section, which took place at 980-1180 cal. years B.P., was of comparable magnitude to the 1848 event. 


\title{
5. RATES OF ACTIVE FAULTING DURING LATE QUATERNARY FLUVIAL TERRACE FORMATION AT SAXTON RIVER, AWATERE FAUlt, NeW ZEALAND
}

\begin{abstract}
In northeastern South Island, New Zealand, 80-100\% of the obliquely-convergent relative motion between the Pacific and Australian plates is accommodated by slip across active dextral-oblique faults in the Marlborough fault system. Refined estimates of late Quaternary strike-slip rates are presented along one of these faults, the Molesworth section of the Awatere Fault. Climatic changes since the last glaciation have resulted in the formation of a flight of 6 fluvial terraces on the Saxton River near Isolated Flat. These well-preserved terraces have been progressively displaced across the Molesworth section of the Awatere Fault, with horizontal displacements ranging from $\sim 6 \mathrm{~m}$ for an ephemeral channel on the youngest terrace to $\sim 77 \mathrm{~m}$ for a bedrock spur above the oldest terrace. New optically stimulated luminescence ages for abandonment of the two oldest terrace treads are $14.5 \pm 1.5$ and 6.69 \pm 0.74 ka B.P. When combined with observed horizontal displacements, these new ages suggest that strike slip has accrued on this part of the Awatere Fault at a near-constant rate of $5.5 \pm 1.5 \mathrm{~mm} / \mathrm{a}$ since $\sim 15 \mathrm{ka}$. Comparing the magnitudes and ages of the terrace riser displacements to the timing of paleoearthquakes on the Molesworth section allows estimation of a mean per-event displacement of $4.4 \pm 0.2 \mathrm{~m}$. An apparent increase in seismicity in the Holocene reduces the magnitude of the youngest per-event displacement estimates to $<2 \mathrm{~m}$. The new terrace ages also allow differentiation of two, separate, late Quaternary aggradational periods by Saxton River. The earlier aggradation was occurring at the Last Glacial Maximum, and persisted until the late Pleistocene. The younger aggradation occurred coevally with a local glacial advance in the early Holocene, and persisted after these glaciers retreated in the early-mid Holocene. The delivery of glacially-accumulated sediment to the river system is inferred to be responsible for the transient continuation of fluvial aggradation following glacial retreat. Rapid incision following abandonment of the youngest aggradation surface may also have resulted in a change in the upthrown side of the Awatere Fault across the youngest Saxton River terraces.
\end{abstract}




\subsection{INTRODUCTION}

In northeast South Island, relative motion between the Pacific and Australian plates at $\sim 073^{\circ} / 253^{\circ}$ is oblique to the average strike of the Marlborough fault system (De Mets et al., 1990, 1994), resulting in oblique slip across those northeast striking faults (e.g., Little et al., 1998; Nicol and Van Dissen, 2002). The Marlborough fault system is a transition zone linking the zone of continental convergence in the Southern Alps, to the south, with the westward-directed Hikurangi subduction margin to the north (Lewis and Pettinga, 1993; Walcott, 1998), and cumulative fault slip rates across this plate boundary zone suggest the Marlborough faults together with local vertical axis rotations accommodate $80-100 \%$ of the relative plate motion (Holt and Haines, 1995; Little and Roberts, 1997). Knuepfer (1992) presented ages, displacements and rates of slip for faulted geomorphic surfaces at 16 sites across the Marlborough fault system, including two sites on the Awatere Fault, and interpreted the results as revealing distinct temporal and spatial variations in late Quaternary slip across this zone of transcurrent faulting. His data suggested a dramatic decrease in lateral slip rate in the last 3-5 ka, which was interpreted to be a manifestation of short-term (i.e. $10^{3}$ years) changes in convergence accommodated across this part of the plate boundary zone. If correct, such a dramatic variation in fault slip rates would have important implications for the tempo and nature of plate boundary processes in active deformation zones such as those in the South Island of New Zealand.

The Awatere Fault is one of four principal strike slip faults in the Marlborough fault system, yet slip rates are well-constrained at only a few sites along its length. This fault is comprised of two geometrically defined fault sections (the eastern and Molesworth sections, Figure 5.1). These intersect at a conspicuous junction near the Molesworth Station homestead in the upper Awatere Valley. While the eastern section has been the focus of several recent neotectonic and paleoseismological studies, the Molesworth section is still poorly documented. Nor is the mechanical significance of the junction resolved. On the eastern section, Little et al. (1998) described the neotectonic geology in detail, presented new thermoluminescence ages for faulted alluvial surfaces in the lower Awatere Valley, and calculated strike slip rates of $7 \pm 1 \mathrm{~mm} / \mathrm{a}$ since $15 \mathrm{ka}$ at a site near Lake Jasper on 


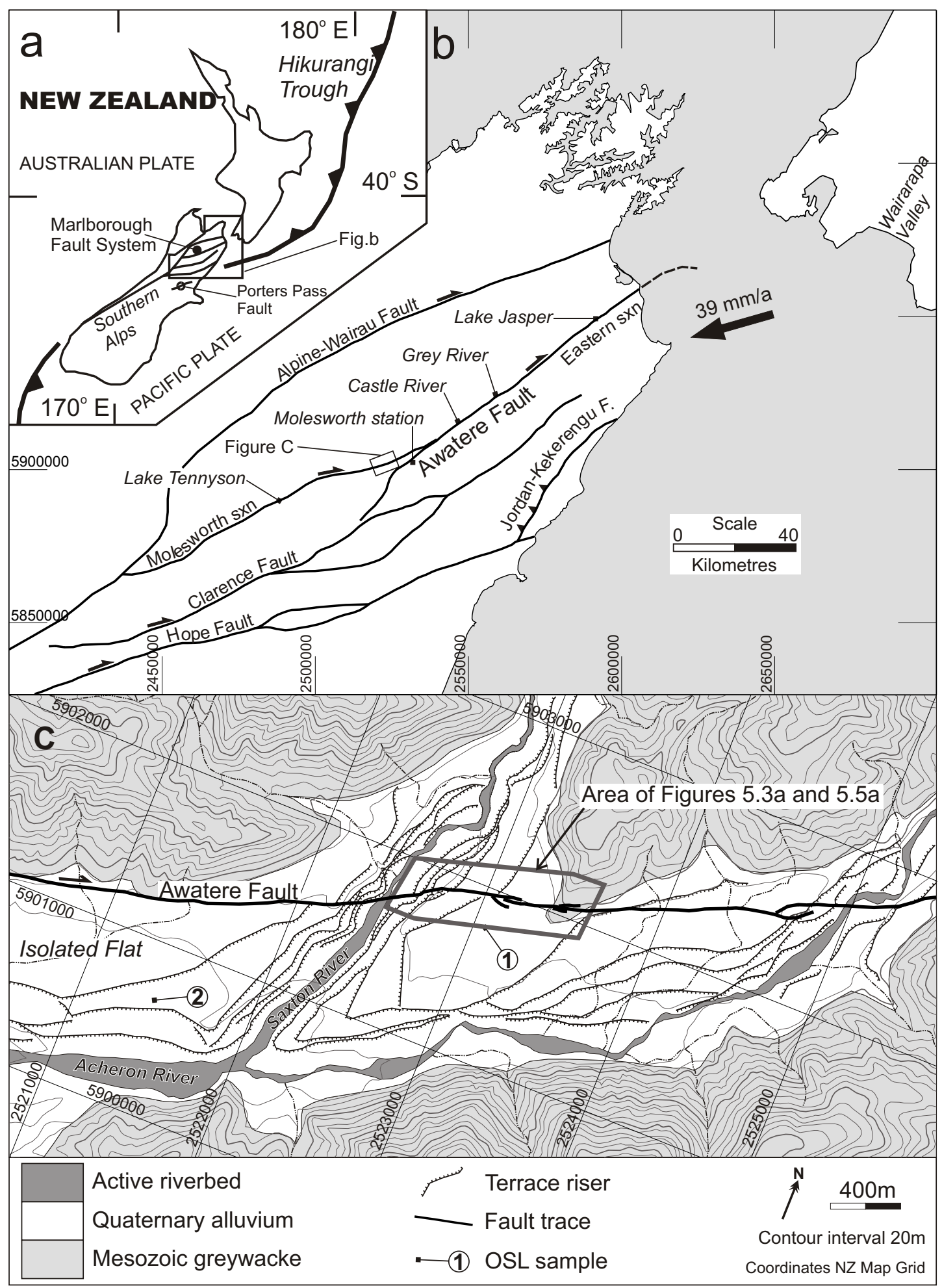

Figure 5.1a-c. (A) Map showing Pacific-Australia plate boundary through New Zealand. (B) Map of the Marlborough fault zone with principal active faults shown (after Carter et al., 1988; Little and Roberts, 1997; Nicol and Van Dissen, 2002). The bold arrow indicates the azimuth and magnitude of Pacific plate motion relative to the Australian plate (de Mets et al., 1990; 1994). (C) Map of the Awatere Fault trace at Isolated Flat. Quaternary alluvium deposited by the Saxton and Acheron Rivers has been cut into a series of terraces since the late Pleistocene and subsequently displaced by the Awatere Fault. The locations of two new OSL samples $(1,2)$ and the area of Figure 5.3a and Figure 5.5a (area of inset) are also shown. 
the South Island's east coast. Benson et al. (2001) revised these slip rates on the basis of new ${ }^{14} \mathrm{C}$ dating of key alluvial terraces near Lake Jasper, calculating constant slip rates of $6 \pm 2 \mathrm{~mm} / \mathrm{a}$ on this section of the Awatere Fault since $20 \mathrm{ka}$. McCalpin (1996a) mapped the Molesworth section from Acheron River to Lake Tennyson and presented slip rates of $\sim 8 \mathrm{~mm} / \mathrm{a}$ based on assumed late Pleistocene ages $(<10 \mathrm{ka})$ for displaced alluvial terrace risers and moraine crests.

\subsection{REGIONAL CONTEXT}

\subsubsection{The displaced terrace sequence at Saxton River}

Near Isolated Flat, in inland Marlborough, the Molesworth section of the Awatere Fault lies at the northern margin of a sedimentary basin that has been infilled with Quaternary alluvium deposited by the Saxton and Acheron Rivers (Figure 5.1). On the eastern side of Saxton River, late Pleistocene aggradational fans have been eroded into a flight of well-preserved fluvial terraces that have been progressively displaced by the Molesworth section of the Awatere Fault (Figure 5.2). These terraces have been used in previous slip rate estimates for the Molesworth section (Lensen, 1973; Knuepfer, 1992; McCalpin, 1996a) and are the focus of this study.

Wellman (1953) mapped four fluvial terraces on the eastern side of Saxton River by aerial photograph analysis, inferring a local fault-strike of $067^{\circ}$, progressively increasing vertical and horizontal offsets of older terrace risers, and tread heights above the modern river level. G. Lensen (unpublished mapping) surveyed the Saxton River area with a measuring tape, stadia rod and theodolite, mapping five terrace surfaces. In combination with low-altitude aerial photographs and the former Department of Lands and Survey's $3^{\text {rd }}$ order triangulation network (pillar 412) for absolute coordinates, Lensen's data were used by New Zealand Aerial Mapping Ltd (NZAM) to create a topographical map of the Saxton River area in 1969 (see Figure 5.3). Lensen (1973) documented fault displacements of the terrace risers and treads, assumed a late-glacial age of $\sim 18 \mathrm{ka}$ for the highest terrace and interpreted a near-uniform rate of horizontal faulting since this time. Knuepfer (1992) presented new ages for the five terraces as mapped by Lensen, based on 

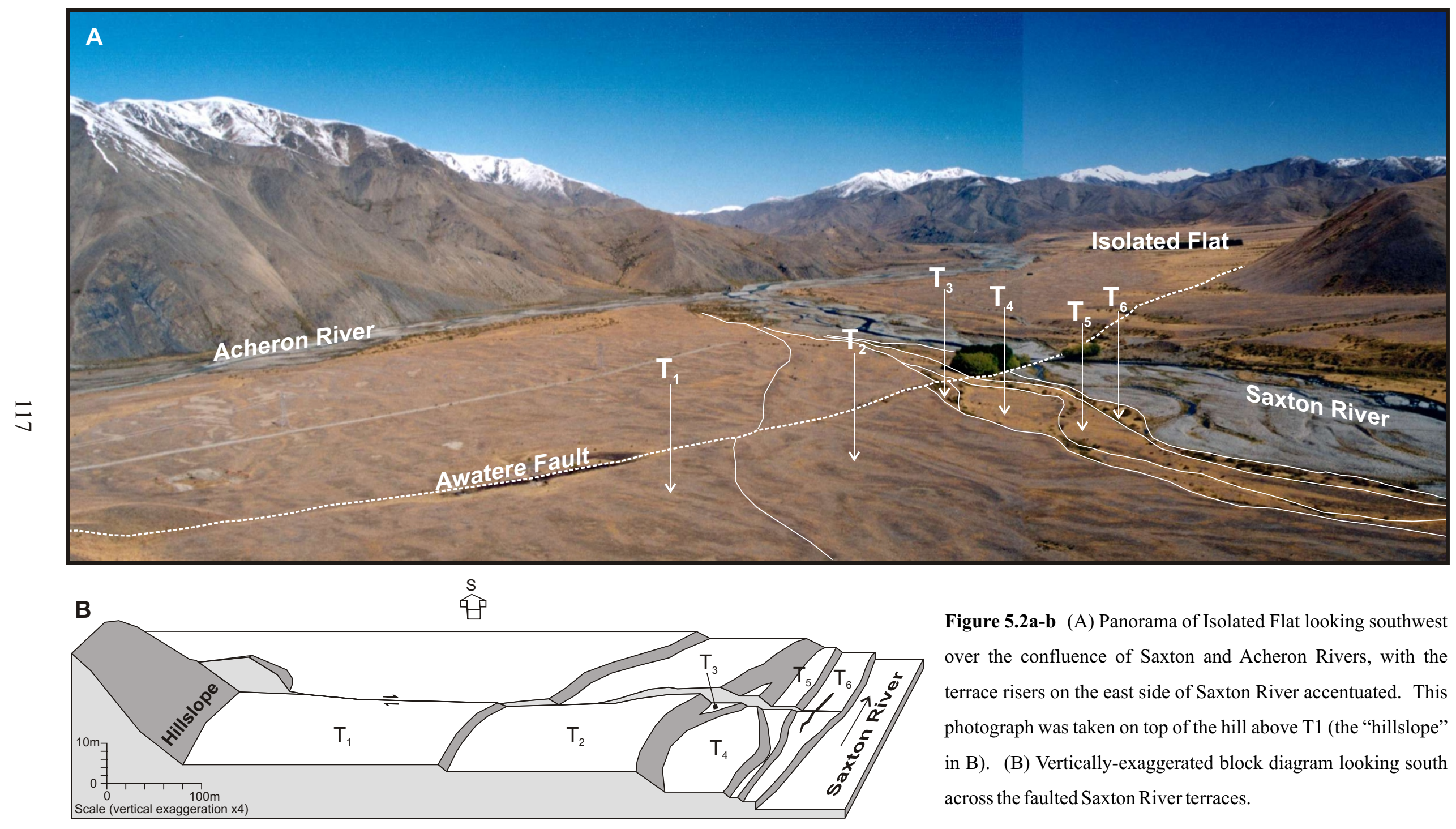

Figure 5.2a-b (A) Panorama of Isolated Flat looking southwest over the confluence of Saxton and Acheron Rivers, with the terrace risers on the east side of Saxton River accentuated. This photograph was taken on top of the hill above T1 (the "hillslope" in B). (B) Vertically-exaggerated block diagram looking south across the faulted Saxton River terraces. 


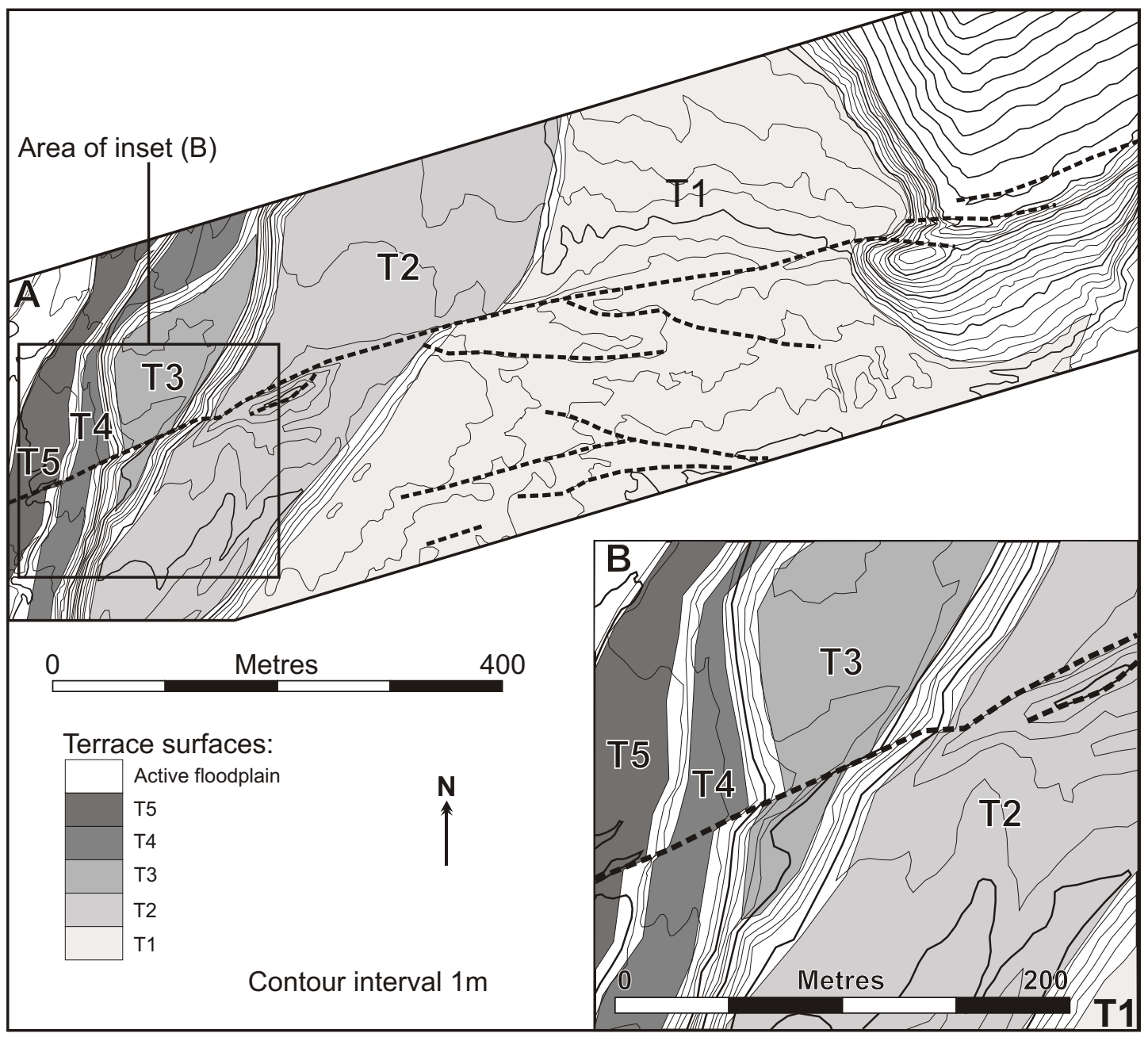

Figure 5.3a-b (A) Adaptation of aerial photo-based map produced by NZAM (1969), showing interpreted terrace geometry. (B) Enlargement surrounding $\mathrm{T}_{3}$ in the vicinity of the fault scarp. 
calibrating pebble weathering rind thickness measurements to rind-growth curves calculated from surfaces with numerical ages (e.g. ${ }^{14} \mathrm{C}$-based ages, see Knuepfer, 1988). McCalpin (1996a) re-measured the fault displacements, presented a new ${ }^{14} \mathrm{C}$ based age for the youngest terrace, and attributed displacement of this terrace to coseismic slip during only the most recent surface rupturing event.

As the well-preserved terraces at Saxton River are a key site in slip rate estimates for the Molesworth section of the Awatere Fault, improvements in surveying and dating technology offer the opportunity to re-evaluate the slip rates at this site, in particular testing the apparent temporal variability in horizontal slip rate observed here by Knuepfer (1992). Accurately measured displacements using microtopographical maps constructed from cm-precision GPS surveys, in combination with new optically stimulated luminescence (OSL) dating of the two highest surfaces, form the basis of this study, which (1) presents new high resolution measurements of the displaced terrace risers and channels on the eastern side of Saxton River, (2) presents new OSL ages of abandonment of the two highest surfaces, (3) presents refined slip rate estimates based on these new data; and (4) discusses the implications of these new data in terms of temporal variations in the rates of active faulting and fluvial terrace formation in the Marlborough fault system. The timing and origin of a late Holocene reversal in the sense of throw across the Awatere Fault, and climatic interpretations of the terrace morphology at Saxton River are also considered here.

\subsubsection{Mechanisms for late Quaternary fluvial terrace formation in central New Zealand}

Fluvial terraces form when the transport capacity of a river exceeds the sediment supply, resulting in the river incising (downcutting) into previouslyaggraded alluvium to leave behind an abandoned terrace tread (Bowen, 1978). The transport capacity of a river depends on the volume of discharge, the slope, and, to a lesser degree, the width and depth of the channel (Leopold et al., 1964). External forces such as climate (e.g., Vella et al., 1988; Eden, 1989; Molnar et al., 1994; Eden et al., 2001) and tectonics (e.g., Rockwell et al., 1984; Ouchi, 1985; Merritts et al., 1994) are variably credited with forcing shifts in the above variables affecting 
transport capacity that result in terrace formation, though climate change appears to be fundamental to terrace formation in almost all known case studies.

Fluvial terraces can therefore offer insight into climate change. In some eastern North Island drainage catchments, significant aggradation of fluvial gravels ceased 17,600 cal. years B.P. (Newnham et al., 2003), which correlates closely with the culmination of the Last Glacial Maximum (Suggate, 1990). This suggests aggradation occurs during glacial conditions, where reduced vegetation cover, increased erosion capacity and insufficient rainfall produce an excess of sediment that cannot be transported, and is consequently aggraded. Conversely, interglacial conditions are associated with increases in regional precipitation, fluvial discharge and catchment vegetation cover, and are correlated with periods of terrace abandonment and river downcutting (e.g., Berryman et al, 2000; Eden et al., 2001). These relationships suggest a simple model where climatic changes from a glacial to an interglacial regime reduce sediment availability and increase stream transport capacity, resulting in a switch from aggradation to incision.

Refined dating of surfaces in northeastern South Island, however, suggests this simple climate-sedimentation model is not necessarily valid for the periglacial Marlborough region. Evidence cited by Eden et al. (2001) for an apparent New Zealand-wide switch from aggradation to incision during the transition from the Last Glacial Maximum to the present interglacial includes abandonment ages of aggradation surfaces in Marlborough. Specifically, the youngest aggradation surface in the lower Awatere Valley (the Starborough-1 terrace) was assigned an abandonment age of $17 \pm 2 \mathrm{ka}$ by Eden (1989), based on estimated loess accumulation rates and the presence of the $\sim 22$ ka Kawakawa Tephra (Aokautere Ash; Pillans et al., 1993) within loess inferred to have derived from the then-active Starborough-1 floodplain. This abandonment age was reinforced by a thermoluminescence age of $15.2 \pm 1.3 \mathrm{ka}$ from loess mantling the Starborough-1 terrace by Little et al. (1998), implying the last major period of aggradation in this region culminated at this time. Townsend (2001) obtained an OSL-based age of abandonment of the Starborough-1 terrace of $9.15 \pm 0.71 \mathrm{ka}$ B.P. and suggested aggradation persisted in this region into the early Holocene, well after the Last Glacial Maximum. Similarly, the frequent preservation of Kawakawa Tephra within localised colluvial and tributary alluvial fans in the coastal Awatere area, but not in 
major along-river aggradation gravel sequences, suggests that significant aggradation on major rivers such as the Awatere River was not taking place during the Last Glacial Maximum (Townsend, 2001). An early post-glacial age of aggradation is also suggested by dating studies of aggradation surfaces in the lower Wairarapa Valley (Shulmeister and Grapes, 2000). While this study does not have a regionalscale focus (e.g., Eden et al., 2001; Townsend, 2001), new age estimates for the Saxton River terraces help to further refine the timing of aggradation in the inland Marlborough region, and its relationship to periods of glaciation and deglaciation.

\subsection{TERRACE MEASUREMENTS}

In this study, Eden's (1989) terrace nomenclature is adopted. The oldest surface is referred to as $T_{1}$ and the youngest abandoned terrace $\left(T_{6}\right)$ is defined as the banks of the modern river floodplain. At Saxton River, 6 abandoned terrace treads are recognised, the oldest of which $\left(T_{1}\right.$ and $\left.T_{2}\right)$ are inferred to represent aggradation surfaces due to the thickness of gravel beneath the terrace treads $(<20 \mathrm{~m}$; see Figure 5.4). Bedrock was not observed in the active channel of Saxton River in the vicinity of the fault trace, which provides a minimum constraint on the thickness of the aggradation gravels if the bedrock strath surface intersects with the hillslope beneath $\mathrm{T}_{1}$. Projecting the hillslope down-plunge below $\mathrm{T}_{1}$ to intersect the bedrock surface gives an estimated maximum gravel thickness of $20 \mathrm{~m}$ beneath $T_{1}$ and $T_{2}$. In the Saxton-2 trench, greywacke was exposed on the locally-upthrown southern side of the sagpond 'graben' (see Chapter 3). This observation gives a minimum thickness of 2-3 $\mathrm{m}$ for the sediments beneath the $\mathrm{T}_{1}$ tread at this site. On the north side of the fault, greywacke was not encountered at the base of the trench, $\sim 6 \mathrm{~m}$ below the $T_{1}$ surface. Thus 2-6 $\mathrm{m}$ is considered a minimum thickness for the $\mathrm{T}_{1}$ gravels.

Terraces $\mathrm{T}_{3}-\mathrm{T}_{6}$ were formed during periods of downcutting, and have relatively thin $(<5-10 \mathrm{~m})$ accumulations of gravel beneath the treads. The recognition of 6 terraces here is a revision of the 5 surfaces mapped by Lensen (1973), Knuepfer (1988; 1992) and McCalpin (1996a). The inference of an added terrace is due to GPS-based surface modelling of the terraces, which allows differentiation between two surfaces $\left(\mathrm{T}_{3}\right.$ and $\left.\mathrm{T}_{4}\right)$, which previous workers considered to be the same surface (see Figure 5.3b). This GPS-based mapping shows $\mathrm{T}_{4}$ has been completely removed on the south side of the fault, in close vicinity to the fault 

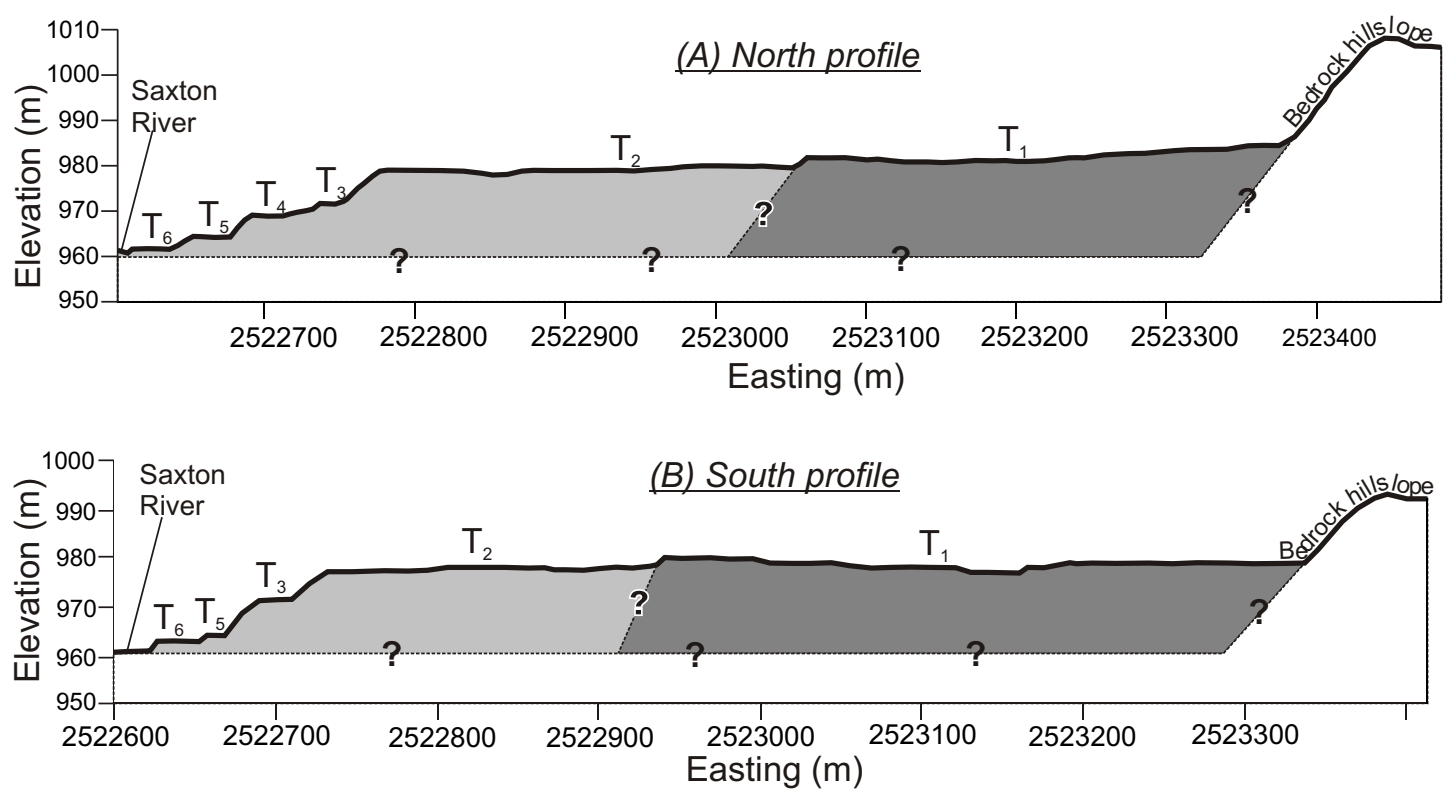

Vertical exaggeration $x 3$

Figure 5.4a-b Fault-parallel, vertically exaggerated, topographic profiles and schematic cross sections of the terrace stratigraphy along the east bank, Saxton River. Based on the inferred gravel thickness below the tread, their morphology and relative position above the modern river, the terrace sequence can be subdivided according to their formation by aggradation $\left(T_{1}\right.$ and $\left.T_{2}\right)$ and incision $\left(T_{3}-T_{6}\right)$ processes. 
scarp (Figure 5.5b). As the risers above and below $\mathrm{T}_{4}$ cannot be matched across the fault, no displacements of the $\mathrm{T}_{3}-\mathrm{T}_{4}$ and $\mathrm{T}_{4}-\mathrm{T}_{5}$ risers can be measured. Therefore, 5 displaced geomorphic features were recognised at Saxton River: one offset bedrock spur to the east of (above) the highest terrace surface; three terrace risers $\left(T_{1}-T_{2}, T_{2}-\right.$ $\mathrm{T}_{3}$, and $\mathrm{T}_{5}-\mathrm{T}_{6}$ ) and an abandoned channel incised into the $\mathrm{T}_{6}$ surface. Below the $\mathrm{T}_{6}$ surface is the active Saxton River floodplain, and therefore the ' $T_{6}$ riser' is the modern river bank, which does not preserve any fault displacement.

\subsubsection{Fault displacements}

All the terraces on the east bank of Saxton River were surveyed using a RealTime Kinematic (RTK) GPS system with points on the ground surface sampled every $2 \mathrm{~m}$. The raw GPS data was processed into New Zealand Map Grid coordinates, gridded with a grid spacing of $0.5 \mathrm{~m}$, and contoured using the terrain modelling programme Surfer v.8 (Golden Software Inc, 2002). Microtopographical maps of individual offsets were created, and these were used to project the offset features to the fault plane, taking into account both the plunge of the feature and the attitude of the fault plane (see Little et al., 1998). The maps created from the GPS surveys are shown in Figure 5.6a-g, fault displacement data are presented in Table 5.1, measurements of the terrace tread widths and riser heights are given in Table 5.2 , and a brief summary of each terrace measurement is given below.

Table 5.1 - Fault displacement data. All offsets are given in metres; the vertical offsets are from this study (a negative vertical offset is upthrown on the south side of the fault). The offset uncertainties (this study) arise from uncertainties in projecting terrace risers and the hillslope to the fault plane.

\begin{tabular}{|c|c|c|c|c|c|}
\hline $\begin{array}{l}\text { Terrace } \\
\text { feature }\end{array}$ & $\begin{array}{c}\text { Lensen } \\
(1973)\end{array}$ & $\begin{array}{c}\text { Knuepfer } \\
(1992)\end{array}$ & $\begin{array}{c}\text { McCalpin } \\
\text { (1996a) }\end{array}$ & This study & $\begin{array}{c}\text { Vertical } \\
\text { offset (m) }\end{array}$ \\
\hline Hillslope & 72 & $66 \pm 5$ & $60-64$ & $76.5 \pm 15.3$ & $2.6 \pm 1.6$ \\
\hline $\mathrm{T}_{1}$ edge & & & & $51.5 \pm 6.3$ & \\
\hline $\mathrm{T}_{1}$ tread & & & & & $3.0 \pm 1.8$ \\
\hline $\mathrm{T}_{1}-\mathrm{T}_{2}$ riser & 72 & $52 \pm 5$ & $62-70$ & $41.2 \pm 9.6$ & \\
\hline $\mathrm{T}_{2}$ tread & & & & & $1.9 \pm 0.2$ \\
\hline$T_{2}-T_{3}$ riser & 37 & $35 \pm 5$ & $35.2-42$ & $34.5 \pm 7.4$ & \\
\hline $\mathrm{T}_{3}$ tread & & & & & $0.7 \pm 0.2$ \\
\hline$T_{3}-T_{4}$ riser & 15 & $15 \pm 4$ & $11.5-12.0$ & - & \\
\hline $\mathrm{T}_{4}$ tread & & & & & - \\
\hline $\mathrm{T}_{4}-\mathrm{T}_{5}$ riser & - & - & - & - & \\
\hline $\mathrm{T}_{5}$ tread & & & & & $-0.5 \pm 0.2$ \\
\hline$T_{5}-T_{6}$ riser & 7.6 & $8 \pm 2$ & $7.2-7.6$ & $9.5 \pm 1.7$ & \\
\hline $\mathrm{T}_{6}$ tread & 6.7 & $7.2 \pm 0.5$ & $7.2-7.6$ & $6.3 \pm 0.8$ & $-0.4 \pm 0.1$ \\
\hline
\end{tabular}




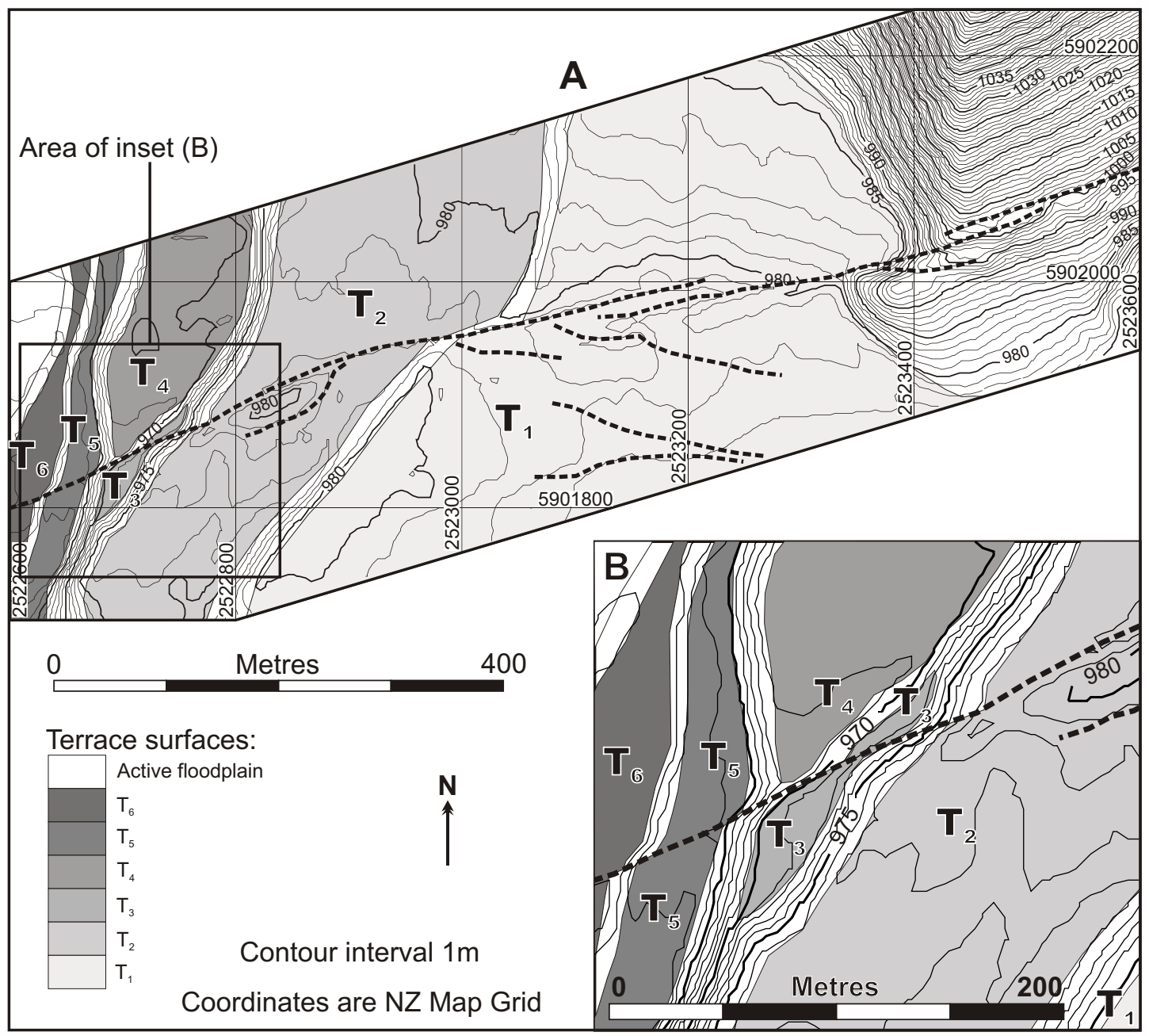

Figure 5.5a-b (A) GPS-based map of the eastern bank of Saxton River, showing the terraces mapped in this study. (B) Enlargement of the same area as Figure 5.3b, showing the revised interpretation of the terraces using GPS-based modelling and contouring of the terrace surfaces. Note the differentiation of two separate surfaces, $\mathrm{T}_{3}$ and $\mathrm{T}_{4}$, which is mapped as only $\mathrm{T}_{3}$ on the NZAM map. 

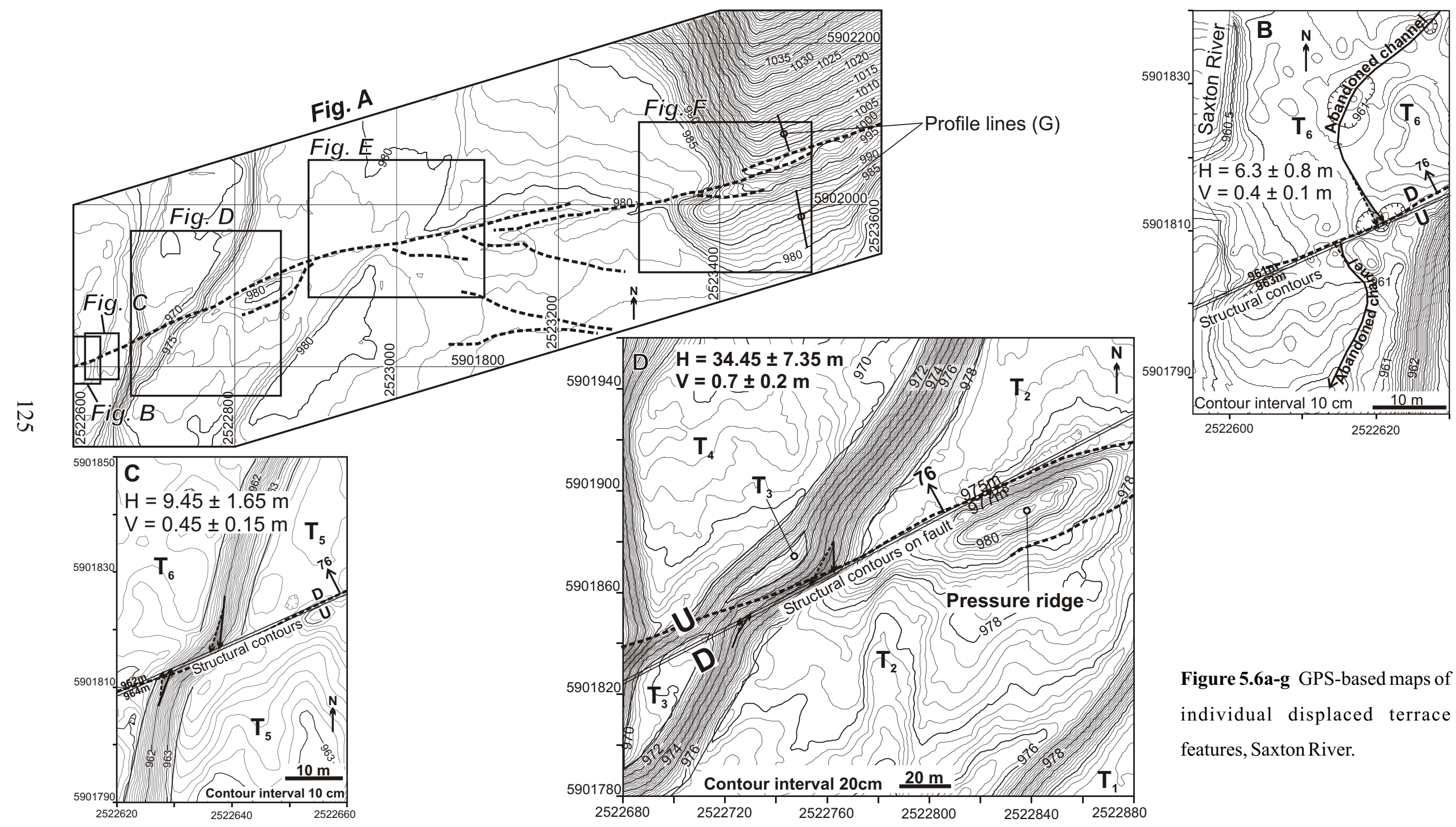

Figure 5.6a-g GPS-based maps of individual displaced terrace features, Saxton River. 

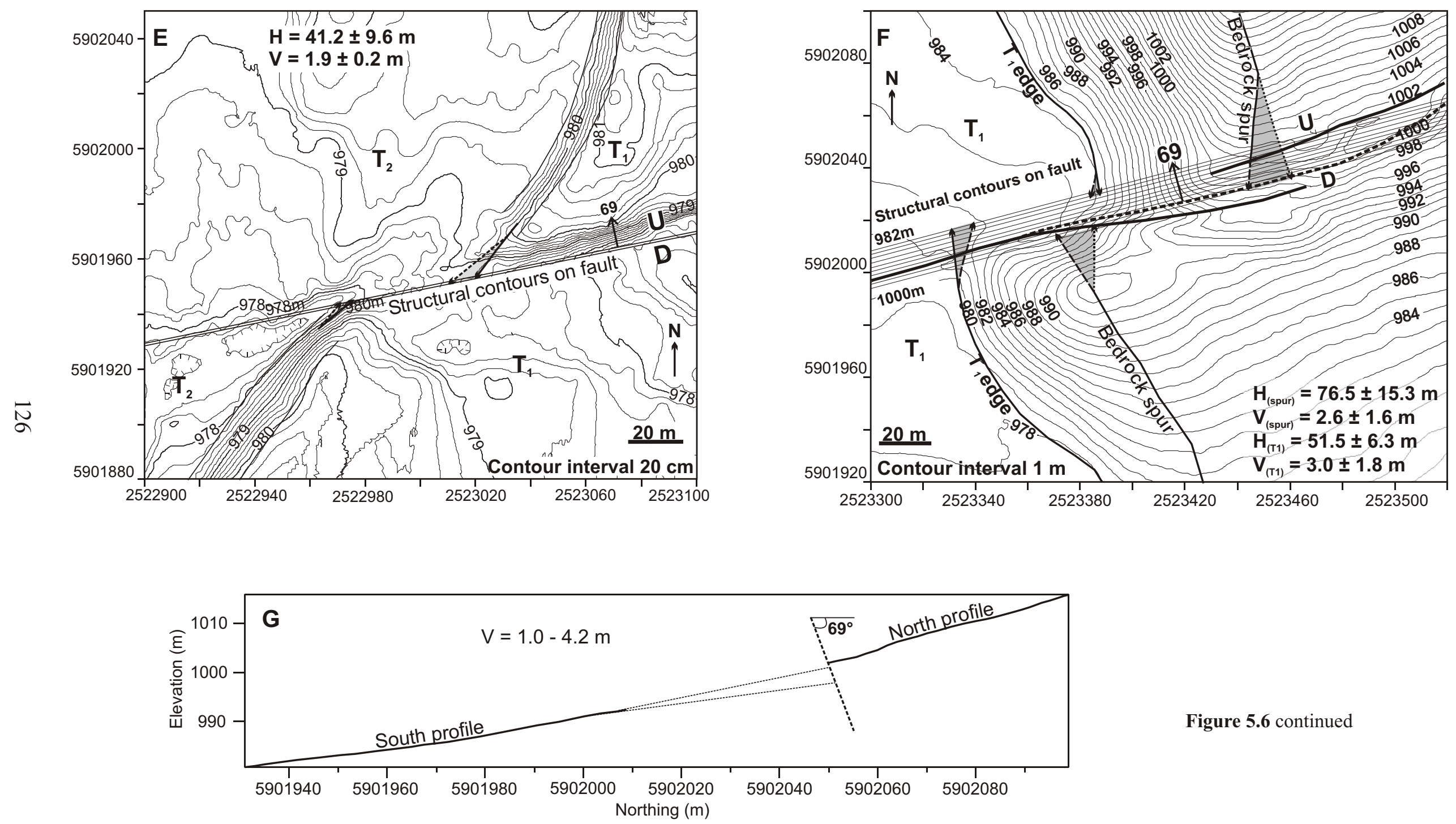

Figure 5.6 continued 
Table 5.2 - Measurements of the tread widths and riser heights of the Saxton River terraces on each side of the Molesworth section of the Awatere Fault.

\begin{tabular}{|l|c|c|c|c|}
\hline Terrace feature & $\begin{array}{c}\text { North tread } \\
\text { width }(\mathbf{m})\end{array}$ & $\begin{array}{c}\text { North riser } \\
\text { height }(\mathbf{m})\end{array}$ & $\begin{array}{c}\text { South tread } \\
\text { width }(\mathbf{m})\end{array}$ & $\begin{array}{c}\text { South riser } \\
\text { height }(\mathbf{m})\end{array}$ \\
\hline $\mathrm{T}_{1}$ tread & 318 & & 359 & \\
\hline $\mathrm{T}_{1}-\mathrm{T}_{2}$ riser & & 2.6 & & 2.1 \\
\hline $\mathrm{T}_{2}$ tread & 255 & & 228 & 6.0 \\
\hline $\mathrm{T}_{2}-\mathrm{T}_{3}$ riser & 13.3 & & & 8.0 \\
\hline $\mathrm{T}_{3}$ tread & & 1.6 & & \\
\hline $\mathrm{T}_{3}-\mathrm{T}_{4}$ riser & 38.5 & & - & - \\
\hline $\mathrm{T}_{4}$ tread & & 4.8 & & \\
\hline $\mathrm{T}_{4}-\mathrm{T}_{5}$ riser & 24.5 & & 12.6 & 1.5 \\
\hline $\mathrm{T}_{5}$ tread & & 2.8 & & \\
\hline $\mathrm{T}_{5}-\mathrm{T}_{6}$ riser & 26.9 & & 25.8 & 2.3 \\
\hline $\mathrm{T}_{6}$ tread & & 1.9 & & \\
\hline Modern river bank & & & & \\
\hline
\end{tabular}

As terrace risers at Saxton River are not vertical, but modified by erosion at the top of the riser and deposition at the base, reference contours approximately halfway down the riser were used as a proxy for an unmodified, sample elevation on the riser. Uncertainties using this technique are largest when the two linear features on each side of the fault have different trends, such as the bedrock spur flanked by terrace $\mathrm{T}_{1}$ (see Figure 5.6g). In this particular case, the spur on the north side of the fault has a trend of $005^{\circ}$, while on the south side it has a trend of $325^{\circ}$. Projections of the maximum and minimum offsets were made by adjusting the trend on each side of the fault to match that on the opposite side. This is based on the assumption that prior to slip and erosion on the fault scarp, each riser segment in close proximity to this feature had a locally identical trend on either side of the fault. Each symmetrical error as quoted in Table 5.1 is the numerical average of the maximum and minimum offsets, and is informally considered to be a $95 \%$ confidence interval containing the true offset.

The flight of terraces at Saxton River show progressively increasing fault displacement with increasing surface height and relative age. The smallest measured displacement is an abandoned channel incised into the $T_{6}$ surface, which is a subtle feature, and hard to measure in the field (e.g., Lensen, 1973). This channel was able to be differentiated on the microtopographic map of the $\mathrm{T}_{6}$ tread, however, allowing 
projection of the remnant channel thalwegs to the fault. The GPS data yielded a horizontal offset for this channel of $6.3 \pm 0.8 \mathrm{~m}$, and a south side-up vertical offset of the $\mathrm{T}_{6}$ surface into which it is incised of $0.4 \pm 0.1 \mathrm{~m}$ (Figure $5.6 \mathrm{~b}$ ). $10-15 \mathrm{~m}$ to the east of this channel is the higher and older $\mathrm{T}_{5}-\mathrm{T}_{6}$ riser, which was measured to be offset along the fault by $9.5 \pm 1.7 \mathrm{~m}$ horizontally and $0.5 \pm 0.2 \mathrm{~m}$ vertically, also with the south side upthrown (Figure 5.6c).

Lensen (1973), Knuepfer (1992) and McCalpin (1996a) all measured horizontal offsets $>10 \mathrm{~m}$ of a "T3" riser. Figure $5.5 \mathrm{~b}$ shows the re-interpretation of the terrace geometry here. Here two terraces $\left(T_{3}\right.$ and $\left.T_{4}\right)$ are distinguished that cannot be assumed to match across the fault rather than a single terrace $T_{3}$ which is offset. $\mathrm{T}_{4}$ is only preserved on the north side of the fault near to the fault scarp. Therefore, no attempt was made to measure any apparent offset of the riser that is immediately above the $\mathrm{T}_{5}$ surface.

Horizontal offset of the $T_{2}-T_{3}$ riser by the fault was measured to be $34.5 \pm 7.4$ m (Figure 5.6d), which is similar to previous measurements by Lensen (1973), Knuepfer (1992) and McCalpin (1996a). The $\mathrm{T}_{3}$ tread adjacent to this riser is vertically offset by $0.7 \pm 0.2 \mathrm{~m}$, with the north side upthrown. On the $\mathrm{T}_{2}$ tread $50 \mathrm{~m}$ to the east of this riser, however, a $5-10^{\circ}$ anticlockwise change (restraining bend) in the strike of the fault has resulted in the formation of a 1-2 m high, $60-80 \mathrm{~m}$ long pressure ridge on the south side of the fault. While formation of this bulge has resulted in localised uplift of the southern side of the fault, $140 \mathrm{~m}$ farther to the east, below the $T_{1}-T_{2}$ riser, the $T_{2}$ tread is upthrown to the north, consistent with the sense of throw of the $\mathrm{T}_{3}$ tread.

Lensen (1973) noted that the $T_{1}-T_{2}$ terrace riser has been offset by the same amount as the bedrock spur (72 $\mathrm{m}$ for both features, see Table 5.1). This observation differs significantly from the GPS-based measurements, which show the riser to be dextrally offset $41.2 \pm 9.6 \mathrm{~m}$ (Figure 5.6e). The differing offset amounts are most likely due to interpretations of the original curvature of the riser; here it is assumed that curvature of this riser derives from the original meandering or braided geometry of the river banks. Projection of the terrace riser to the fault trace was therefore made along the trend of the riser, rather than orthogonal to the fault trace, resulting in the measurement of a smaller horizontal separation. Vertical offset of the $T_{2}$ tread 
below this riser was measured to be $1.9 \pm 0.2 \mathrm{~m}$, upthrown to the north. The $\mathrm{T}_{1}$ tread is upthrown by a similar amount $<200 \mathrm{~m}$ to the east, although right-stepping, bifurcating fault strands on this tread have formed two $\sim 50 \mathrm{~m}$ long transtensional sagponds in the downthrown 'graben' between the fault scarps, and total offset of $\mathrm{T}_{1}$ may actually be near $0 \mathrm{~m}$.

The displaced bedrock spur at the eastern edge of the Saxton terraces has accrued the largest horizontal offset of $76.5 \pm 15.3 \mathrm{~m}$ (Figure 5.6f). The $\pm 15 \mathrm{~m}$ uncertainty in the horizontal separation arises from the different trends of the ridge crest, which is most likely due to bevelling and trimming of the hillslope on the northern side of the fault. The vertical offset is not well constrained, and was deemed immeasurable by previous workers as erosion and tectonic deformation have resulted in a zone of slumping and bulging adjacent to the fault scarps. To estimate the vertical offset, fault-perpendicular profiles of the tectonically-undeformed hillslope were constructed and projected to the fault (Figure 5.6g). The fault-parallel separation between the profiles yielded a vertical offset estimate of $2.6 \pm 1.6 \mathrm{~m}$ (north side upthrown).

\subsubsection{Tread widths}

Lensen (1964a) noted that faulting during a period of fluvial downcutting or lateral erosion will produce displaced river banks that are trimmed in the period between earthquakes. This results in differences in the tread widths across the fault that are concomitant with the older, preserved fault displacements. Similarly, vertical displacement of an active floodplain will be trimmed on the upthrown side of the fault and aggraded on the downthrown side. This results in differences in the tread heights across the fault. Measurements of both the tread width and riser height differences across the fault may, in theory, provide a useful test of the accuracy of fault displacement measurements. A graphical summary of Lensen's model is given in Figure 5.7; here a flight of hypothetical fluvial terraces A, B and C is shown, with $\mathrm{A}$ and $\mathrm{B}$ abandoned terrace treads and $\mathrm{C}$ the active floodplain. In this model, the river flows southward, and the oblique-slip fault displays dextral strike-slip and north-up vertical slip. These parameters suggest that following an increment of fault slip the leading edge terrace riser (the river bank on the south side of the fault) will be laterally trimmed by the same amount as the fault has moved horizontally, decreasing the width of the tread above that riser by this amount. Similarly, the north 
1
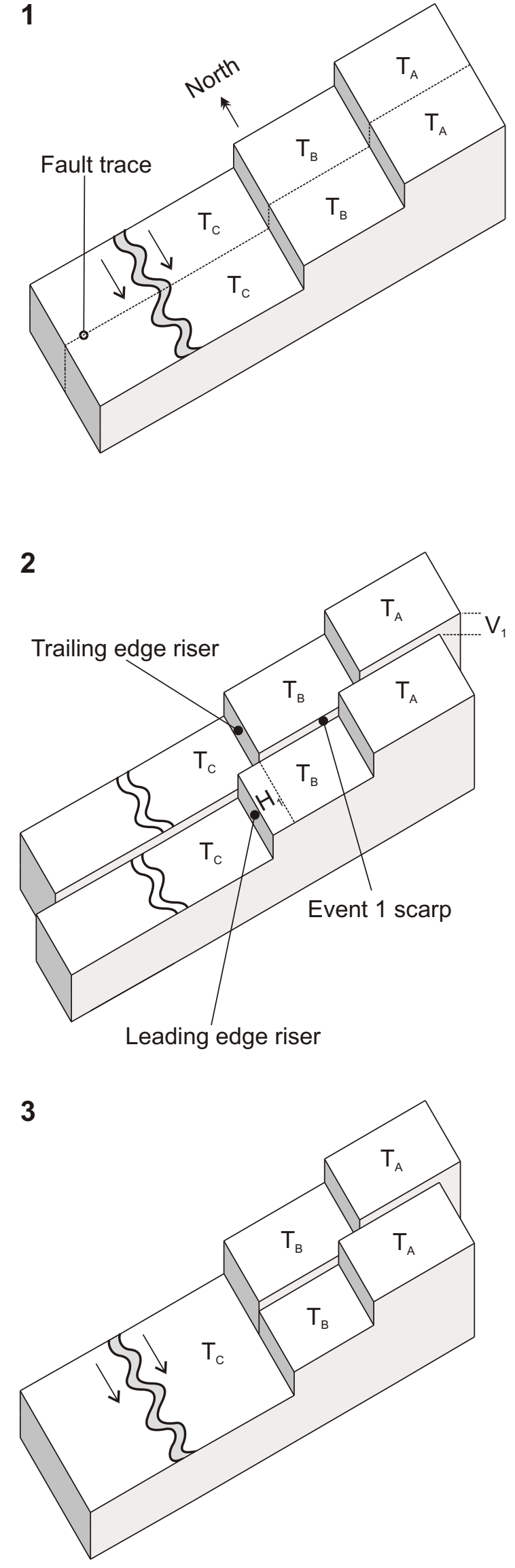

Figure 5.7 Idealised history of progressive fault displacement during fluvial downcutting.

(1) Prefaulting: Abandonment of $T_{B}$ occurs, followed by downcutting to $\mathrm{T}_{\mathrm{C}}$. Tread widths of $B$ are the same on both sides of the fault. The trace of the Event 1 rupture is shown (dotted line).

(2) Faulting Event 1: Displacement of all terraces occurs by horizontal increment $\mathrm{H}_{1}$ and vertical increment $V_{1}$.

(3) First interseismic period: Trimming of the leading edge $T_{B}-T_{C}$ riser (river bank) occurs so that the northern tread of $T_{B}$ is now wider than the southern tread. This width difference is equal to the offset of the $T_{A}-T_{B}$ riser. Downcutting of the upthrown side of the fault ( \pm aggradation on the downthrown side) occurs so that the $T_{B}-T_{C}$ riser is now higher on the north side of the fault. This height difference is equal to the vertical offset of the $T_{B}$ tread. 
4

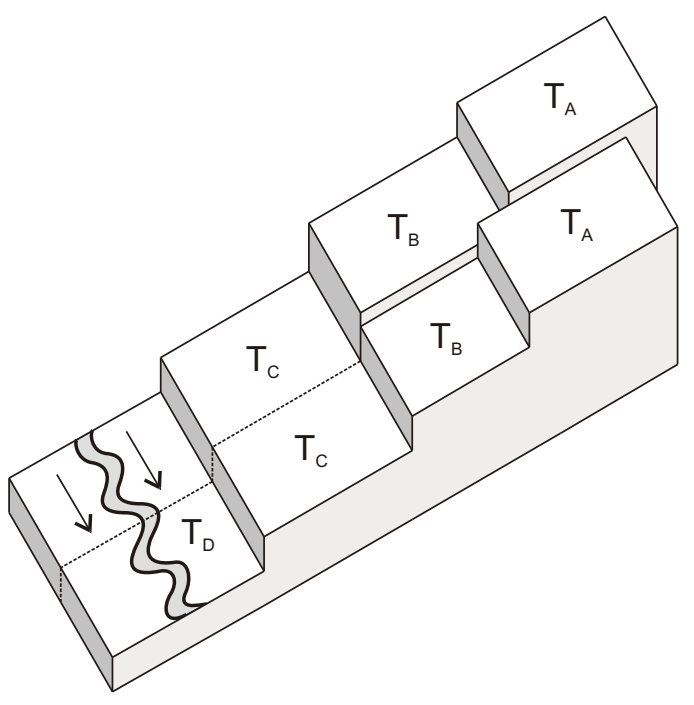

5

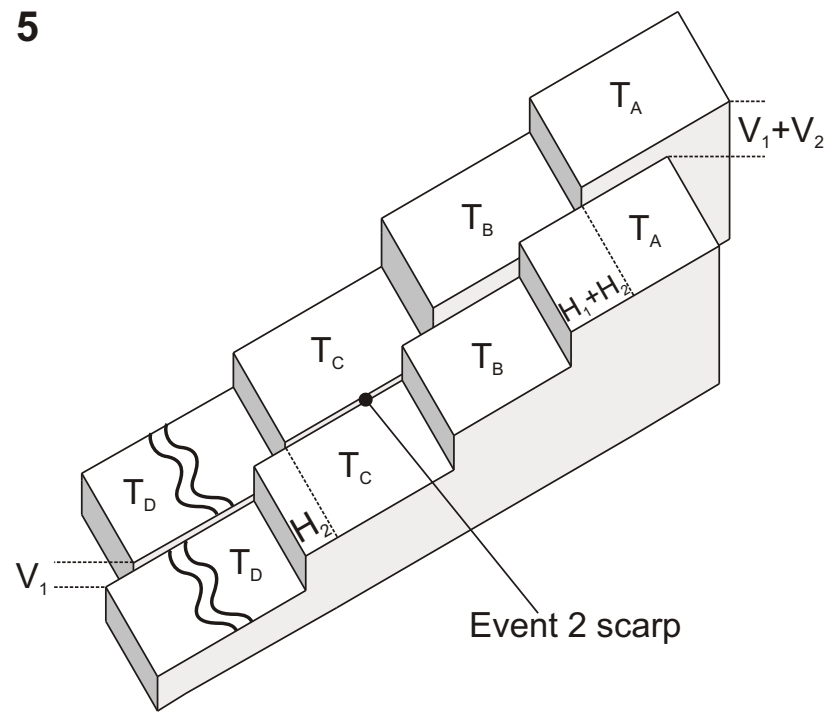

6

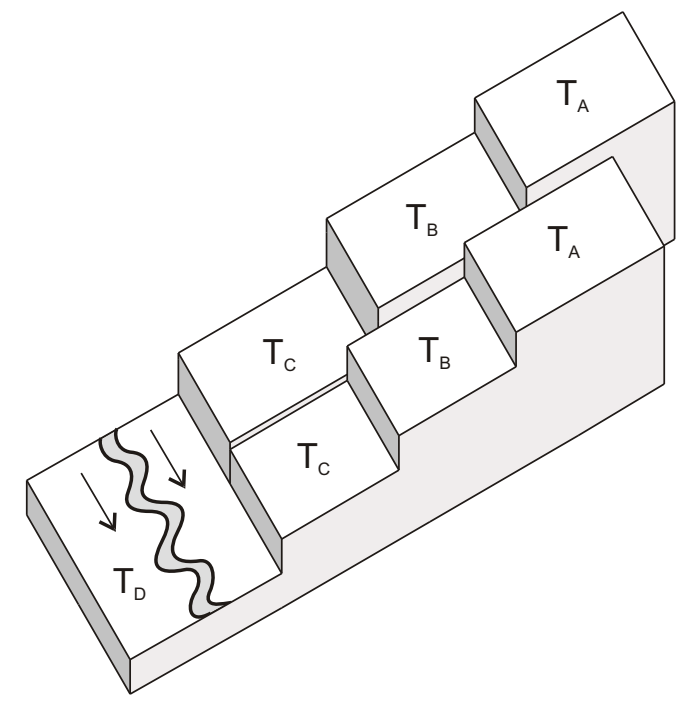

Figure 5.7 continued

(4) Second interseismic period: Terrace C is abandoned, and terrace D is occupied. The tread width of $T_{C}$ is initially the same on both sides of the fault. The trace of the Event 2 rupture is shown on $T_{C}$ and $T_{D}$.

(5) Faulting episode 2: Displacement of all terraces occurs by horizontal increment $\mathrm{H}_{2}$ and vertical increment $\mathrm{V}_{2}$. The $\mathrm{T}_{\mathrm{A}}$ tread is now vertically offset by $V_{1}+V_{2}$, the $T_{A}-T_{B}$ riser is horizontally offset by $\mathrm{H}_{1}+\mathrm{H}_{2}$, the $\mathrm{T}_{B}$ tread is vertically offset by $V_{1}+V_{2}$, the $T_{B}{ }^{-}$ $\mathrm{T}_{\mathrm{C}}$ riser is horizontally offset by $\mathrm{H}_{2}$ only, the $T_{C}$ tread is vertically offset by $V_{2}$ only, the $\mathrm{T}_{\mathrm{C}}-\mathrm{T}_{\mathrm{D}}$ riser (active river bank) is horizontally offset by $\mathrm{H}_{2}$, and the $T_{\mathrm{D}}$ tread (active river floodplain) is vertically offset by $\mathrm{V}_{2}$.

(6) Third interseismic period: Trimming of the leading edge $T_{C}-T_{D}$ riser (river bank) occurs so that the northern tread of $T_{C}$ is now wider than the southern tread. This width difference is equal to the offset of the $T_{B}-T_{C}$ riser. Downcutting of the upthrown side of the fault ( \pm aggradation on the downthrown side) occurs so that the $T_{C}-T_{D}$ riser is now higher on the north side of the fault. This height difference is equal to the vertical offset of the $T_{C}$ tread. 
side of the fault is upthrown, and therefore the floodplain on this side of the fault will be eroded. As the river banks are laterally trimmed, the river bank on the north side of the fault increases in height as this side is downcut.

If the active river banks are completely trimmed between earthquakes, then a terrace riser would only start accruing displacement once the surface below it is abandoned. Under such a scenario, the tread width difference of $\mathrm{T}_{\mathrm{B}}$ should be equal to the offset of the $\mathrm{T}_{\mathrm{A}}-\mathrm{T}_{\mathrm{B}}$ riser, giving an indication of the lateral faulting that occurred following abandonment of $\mathrm{T}_{\mathrm{B}}$ and during the river's downcutting and occupation of $\mathrm{T}_{\mathrm{C}}$. Any disparity between these two measurements suggests there was some preserved offset of the river banks after abandonment of $T_{B}$ and prior to abandonment of $\mathrm{T}_{\mathrm{C}}$. Importantly, this mathematical case requires the terrace tread that is trimmed to be equal to or narrower than the opposite side of the fault following abandonment of the next-younger tread. On the east side of Saxton River, dextral slip across the Awatere Fault would create a modified channel geometry conducive to localised trimming of the offset river bank on the south side of the fault (= the leading edge riser). Lensen's (1964a) model suggests that abandoned terraces on the south side of the fault would have narrower terrace treads than on the north side, with the width difference equal to the magnitude of offset of the riser above the tread in question.

Lensen's argument, however, assumes a mathematically ideal geometry where terrace risers and channels are oriented perpendicular to a single, linear fault trace. Such a fault-orthogonal channel geometry does not exist at Saxton River, so that analyses of fault offset that take into account differences in fault-parallel tread widths here do not significantly improve our understanding of the incremental slip history of this fault relationship to terrace abandonment events. The tread width of $\mathrm{T}_{1}$ increases downstream, due to its lobate plan-form, and is thus wider on the south side of the fault. This observation is opposite to that expected for trimming of this side of the fault, and the tread width difference of this terrace therefore does not clarify the observed displacements. Downstream changes in the width of the $T_{2}$ tread do fit Lensen's model. If the south riser was completely trimmed during downcutting between $T_{2}$ to $T_{3}$, then the difference in tread widths should be equal to the difference in offset of the $T_{1}-T_{2}$ and $T_{2}-T_{3}$ risers. The tread width difference is 25 
$\mathrm{m}$ (Table 5.2), and the difference in riser offsets is $23.7 \mathrm{~m}$ (at $95 \%$ confidence) if the minimum $\mathrm{T}_{2}-\mathrm{T}_{3}$ offset $(27.1 \mathrm{~m})$ is subtracted from the maximum $\mathrm{T}_{1}-\mathrm{T}_{2}$ offset $(50.8$ $\mathrm{m})$. As the 'symmetrical' offsets given in Table 5.1 are numerical means of reasonable riser projections (Figure 5.6c-d), they do not necessarily preclude this apparent accordance of slip estimates. Accordingly, the $\mathrm{T}_{2}-\mathrm{T}_{3}$ riser may have been completely trimmed prior to abandonment of $\mathrm{T}_{3}$, after $\sim 25 \mathrm{~m}$ of dextral slip in the $\mathrm{T}_{2^{-}}$ $\mathrm{T}_{3}$ time period. The data are not precise enough, however, to use the terrace width differences to resolve the amount of lateral trimming that may have taken place between the $T_{2}$ and $T_{3}$ abandonment events.

Differences in tread widths for terraces younger than $T_{2}$ do not provide further insight into progressive fault displacement: $T_{3}$ is only preserved as small terrace fragments adjacent to the scarp apron, $\mathrm{T}_{4}$ has been removed from the south side of the fault, and $\mathrm{T}_{6}$ is being trimmed by the modern river and only has a minimal tread width difference. As $\mathrm{T}_{4}$ has been completely trimmed on the south side of fault, there is no reference riser above $T_{5}$ that can be matched across the fault, and thus Lensen's (1964a) model cannot be applied to $\mathrm{T}_{5}$.

\subsection{TERRACE ABANDONMENT AGES}

Knuepfer (1988) presented new ages for the Saxton River terraces based on modal thicknesses of weathering rinds developed on Torlesse sandstone cobbles on the terrace surfaces, calibrated to established rind-growth curves (e.g., Chinn, 1981; McSaveney, 1992). The stated accuracy of the ages obtained using this method is \pm 5 $- \pm 40 \%$ (Knuepfer, 1988). For this study, samples from the base of $<1.5 \mathrm{~m}$ thick sandy silt accumulations on the $T_{1}$ and $T_{2}$ treads were dated in the Victoria University of Wellington (VUW) luminescence laboratory by optically stimulated luminescence (OSL) dating (see Figure 5.8). The deposition ages for these sediment samples were determined using the multiple aliquot additive-dose method, with latelight subtraction. The OSL-ages were calculated by dividing the equivalent dose $\left(D_{e}\right)$ by the doserate $(\mathrm{dD} / \mathrm{dt})$. In this technique the equivalent dose (the radiation dose that has accumulated in the sample since its last exposure to light) was determined by measuring the blue luminescence output during infrared optical stimulation ( $\alpha$ and $\beta$-irradiation, which selectively stimulated the feldspar fraction). Extrapolation of the luminescence growth curve ( $\beta$-induced luminescence activity vs 


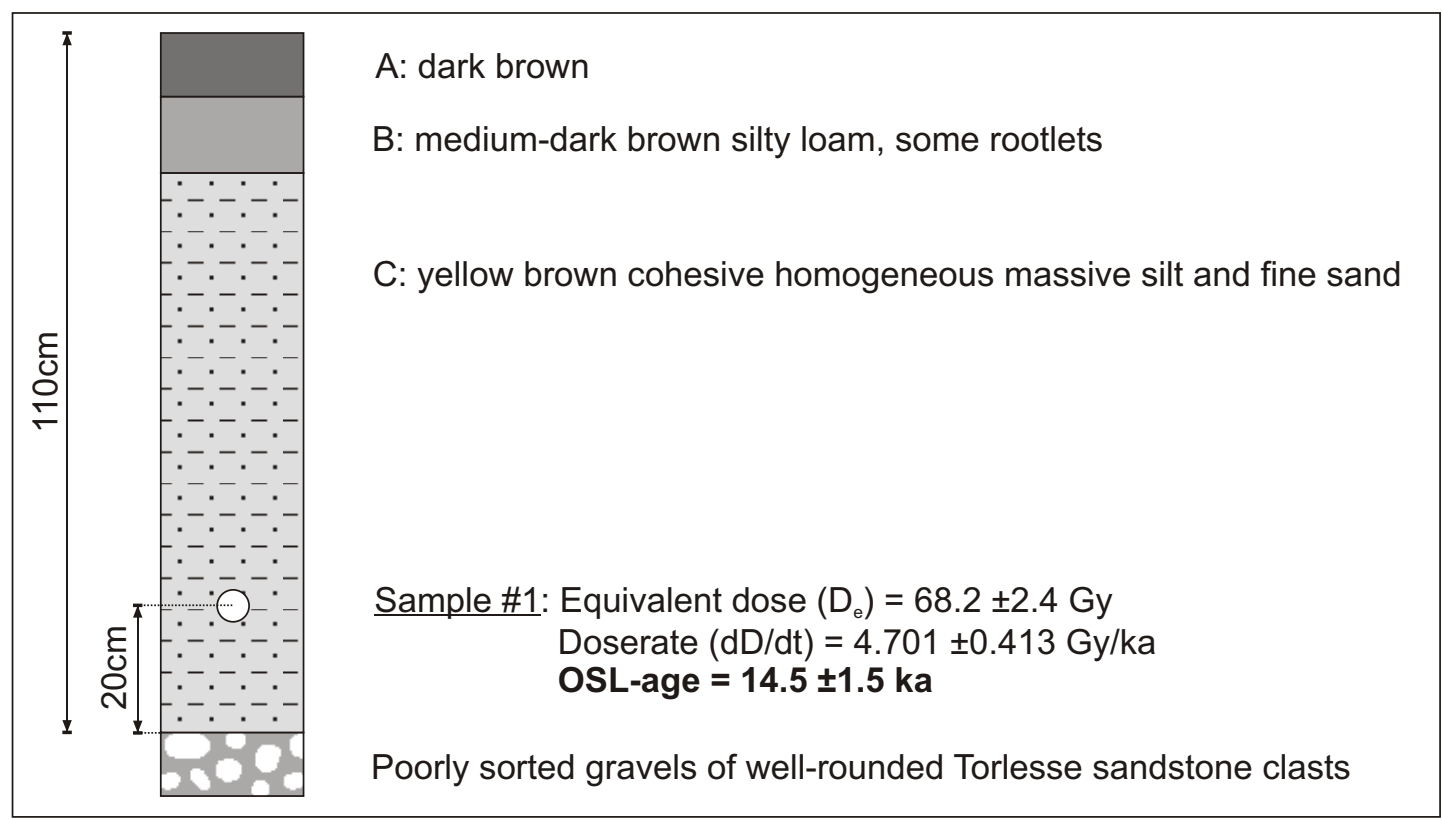

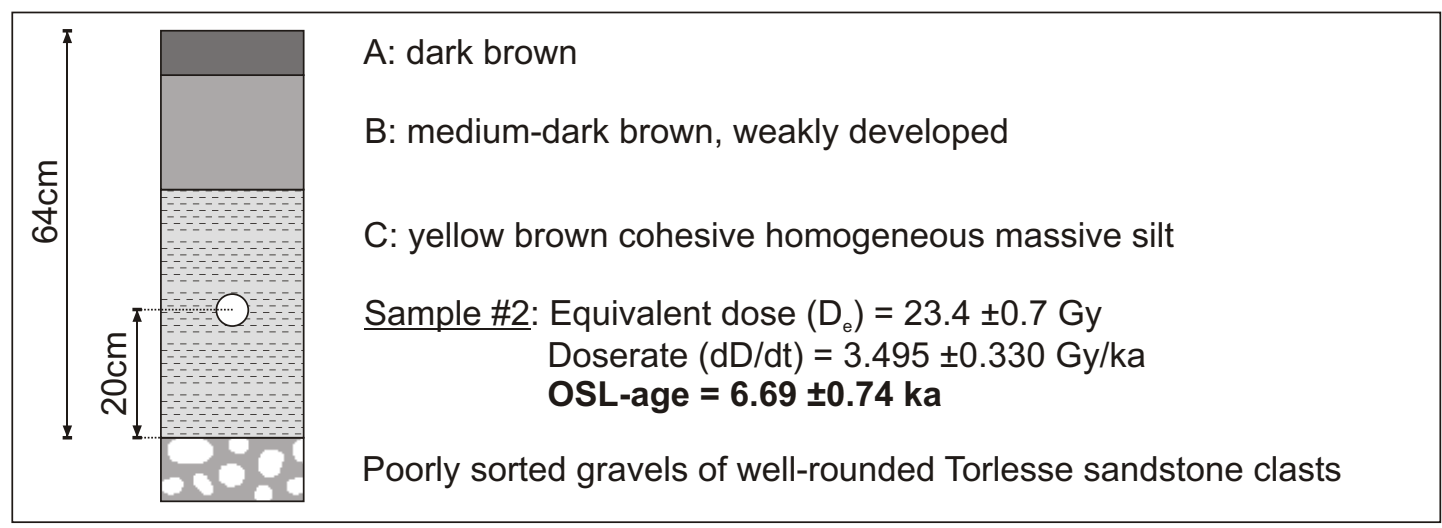

Figure 5.8 Stratigraphy of the Saxton River OSL samples, taken from yellow-brown silt (?loess) on the $\mathrm{T}_{1}$ (sample 1) and $\mathrm{T}_{2}$ (sample 2) treads; the circle marks the position of the sample. Listed for each sample are the equivalent dose (used as a proxy for the paleodose), the doserate and the OSL-age. The OSL age is calculated by dividing the equivalent dose by the doserate. 
added dose) to the dose-axis gives the equivalent dose. This was assumed to represent the paleodose (the radiation dose that has accumulated in the sample since its deposition). The doserate was estimated on the basis of a low gammaspectrometry measurement. None of the samples exhibited indications of anomalous fading (Rieser, 2002). The sampled sediment accumulations are lobate, anastomosing lenses forming remnant interfluves between gravel-based meander channels. These were possibly deposited when the terraces were last occupied. This suggests that during aggradation of the gravels, $<1 \mathrm{~m}$ thick accumulations of silt and fine sand were deposited as overbank levees and crevasse channel fans (e.g., Miall, 1992). The OSL ages are therefore considered to be minimum ages for abandonment of the terraces. If, however, the silt accumulations are aeolian deposits, blown from the active Saxton and Acheron River floodplains, then the OSL ages will underestimate the tread abandonment age. Extrapolating the OSL ages to the terrace tread, assuming a constant accumulation rate and an age of $0 \mathrm{ka}$ for the ground surface, would yield maximum ages for the terraces. The various estimates of the age of abandonment of the terrace treads are given in Table 5.3, and each estimate is discussed below.

Table 5.3 - Terrace tread ages

\begin{tabular}{|c|c|c|c|}
\hline Terrace & $\begin{array}{c}\text { Pebble weathering } \\
\text { rind age (yrs) }\end{array}$ & $\begin{array}{c}{ }^{14} \mathbf{C} \text {-based age } \\
\text { (cal. yrs) }\end{array}$ & OSL age (yrs) $^{3}$ \\
\hline$T_{1}$ & $9410 \pm 1570$ & - & $14500 \pm 1500^{*}$ \\
\hline$T_{2}$ & $7150 \pm 1100$ & - & $6690 \pm 740^{*}$ \\
\hline$T_{3}$ & $? 5460 \pm 770$ & - & - \\
\hline$T_{4}$ & $5460 \pm 770$ & - & - \\
\hline$T_{5}$ & $4000 \pm 1000$ & - & - \\
\hline$T_{6}$ & $2000 \pm 500$ & $1172 \pm 111$ & - \\
\hline
\end{tabular}

Age sources: ${ }^{1}$ Knuepfer (1992); ${ }^{2}$ McCalpin (1996a); ${ }^{3}$ this study

* These samples showed a radioactive disequilibrium, and the quoted OSL ages are corrected for that. As the correction had to be done under the assumption that the disequilibrium was in a steady state for the whole time after deposition, the corrected age represents only a better estimate than the equilibrium age, and not necessarily the true age. Without the correction, the ages would be $\mathrm{T}_{1}: 14.1$ $\pm 1.3 \mathrm{ka}$ and $\mathrm{T}_{2}: 6.31 \pm 0.64 \mathrm{ka}$ (Rieser, 2002).

Knuepfer (1988) calculated a pebble weathering rind age of $9.41 \pm 1.57 \mathrm{ka}$ for $\mathrm{T}_{1}$. The new OSL sample from silt $20 \mathrm{~cm}$ above the terrace gravels, however, 
yielded an age of $14.5 \pm 1.5 \mathrm{ka}$, significantly older than the weathering rind age. If the silt on the $T_{1}$ tread is aeolian, then this OSL age will underestimate the abandonment age of the terrace tread. Assuming a linear rate of silt accumulation on this surface, and that silt at the ground surface has an age of $0 \mathrm{ka}$, the $20 \pm 5 \mathrm{~cm}$ of silt below this OSL sample represents $3.2 \pm 0.9 \mathrm{ka}$ of accumulation. Extrapolating downward from the OSL sample to the silt-gravel contact yields a maximum age of $17.7 \pm 5.2 \mathrm{ka}$ for abandonment of this terrace. Because the silt is assumed to be fluvial, coevally deposited with aggradation of the gravels, this extrapolated age probably overestimates the true age. If the assumption of fluvial deposition is valid, then the OSL age by itself represents the best estimate of the time of abandonment of $\mathrm{T}_{1}$. The large age difference between this and the pebble weathering rind age is most likely due to the presence of the silt cover (from which the OSL sample was taken) which possibly inhibited rind development on the $\mathrm{T}_{1}$ gravels. Despite only surface clasts being selected for weathering rind measurement (Knuepfer, 1988), the pebble age may underestimate the true age because cobbles presently exposed at the surface may have been previously buried by silt for an extended period of time pre-dating their last exhumation.

The second OSL sample from the base of the silt cover on $T_{2}$ yielded an age comparable to Knuepfer's (1988) weathering rind age for that same terrace. The OSL age of this terrace is $6.69 \pm 0.74 \mathrm{ka}$, compared to Knuepfer's weathering rind age of $7.41 \pm 1.1 \mathrm{ka}$. If, as explained above, the silt is aeolian, and has accumulated at a constant rate since abandonment of $\mathrm{T}_{2}$, then an extrapolated age from the OSL sample to the tread would be $9.7 \pm 3.1 \mathrm{ka}$.

The OSL age of the $T_{2}$ terrace suggests weathering rind calibrations return more accurate ages for younger surfaces, consistent with the exponential decay pattern of weathering rind growth curves (Chinn, 1981). Given this observation, Knuepfer's (1988) weathering rind ages for treads $T_{3}-T_{6}$ are adopted for slip rate calculations in this study, though with some qualification. $T_{3}$ was not differentiated by Knuepfer (1988), and thus his pebble weathering rind age of $5.46 \pm 0.77 \mathrm{ka}$ for the $\mathrm{T}_{4}$ terrace is used here as a minimum age for the $\mathrm{T}_{3}$ terrace. The similar morphology of the two surfaces suggests they are close in age, and using Knuepfer's $\mathrm{T}_{4}$ age for the older $\mathrm{T}_{3}$ surface should not introduce any significant errors. Abandonment of $\mathrm{T}_{5}$ was dated by pebble weathering rind calibration as $4.0 \pm 1.0$ ka (Knuepfer, 1988). 
Two ages have been offered for $\mathrm{T}_{6}$ : a pebble weathering rind age of $2.0 \pm 0.5 \mathrm{ka}$, which is attributed to deposition of the $\mathrm{T}_{6}$ gravels (Knuepfer, 1988) and a ${ }^{14} \mathrm{C}$ age of $1.172 \pm 0.111 \mathrm{ka}$ from silty channel-fill and overbank sediments on the $\mathrm{T}_{6}$ tread, which provides a minimum age for abandonment of $\mathrm{T}_{6}$ (McCalpin, 1996a).

\subsection{SLIP RATES}

Calculating the rates at which fault displacements accumulated requires interpretations of the age at which these features began to preserve fault slip. At Saxton River, the modern river is actively trimming the $\mathrm{T}_{6}$ riser (the modern river bank), removing any fault displacement. Knuepfer (1992) made similar observations throughout the Marlborough fault system where modern river banks are cut by active faults. Correspondingly, as shown above, the width of the $T_{2}$ tread (in comparison with offset of the $T_{1}-T_{2}$ riser) suggests the $T_{2}-T_{3}$ riser was completely trimmed ("zeroed") during downcutting to $T_{3}$. Displacement of the $T_{2}-T_{3}$ riser is therefore assumed to have begun to accumulate following abandonment of $\mathrm{T}_{3}$, and the age of $T_{3}$ abandonment thus provides a minimum age for the total offset of the $T_{2}-T_{3}$ riser. This relationship forms the basis for all the slip rate calculations: horizontal displacement of a terrace riser is dated by the age of the tread below that riser. If incorrect, this assumption will yield a maximum slip rate estimate, because incomplete trimming prior to abandonment of the lower surface means that some of the observed riser offset is "inherited" from the previous river bank geometry. A summary of the slip rates calculated in this way is given in Table 5.4. Given the unequal standard deviations of the offset error and age error, slip rates with symmetrical errors $\left(\mathrm{s}^{*} \pm \sigma^{*}\right)$ were calculated using Geyh and Schliecher's division rule (McCalpin, 1996b) to obtain a symmetrical slip rate error:

$$
\begin{aligned}
& \mathrm{s}^{*}=\left(d_{1} / t_{1}\right) \\
& \sigma^{*}=s^{*} \sqrt{\left(d_{2}^{2} / d_{1}^{2}\right)+\left(t_{2}^{2} / t_{1}^{2}\right)}
\end{aligned}
$$

Where $\mathrm{s}^{*}$ is the mean slip rate, $\sigma^{*}$ is the symmetrical slip rate error, $\mathrm{d}_{1}$ is the mean displacement, $t_{1}$ is the mean age, $d_{2}$ is the symmetrical displacement error 
(informal 95\% confidence interval that contains the true displacement), and $t_{2}$ is the age error.

Table 5.4 - Horizontal fault slip rates for displaced features. Slip rates were calculated by pairing the offset with the age of the terrace below the displaced feature, except for the channel on the $T_{6}$ surface, which was dated.

\begin{tabular}{|c|c|c|c|c|c|}
\hline $\begin{array}{l}\text { Terrace } \\
\text { feature }\end{array}$ & Age (yrs)† & $\begin{array}{l}\text { Lateral } \\
\text { offset } \\
(\mathrm{m})\end{array}$ & $\begin{array}{c}\text { Lateral slip } \\
\text { rate } \\
(\mathrm{mm} / \mathrm{a})\end{array}$ & $\begin{array}{c}\text { Vertical } \\
\text { offset } \\
(\mathrm{m})^{*}\end{array}$ & $\begin{array}{l}\text { Vertical } \\
\text { slip rate } \\
(\mathrm{mm} / \mathrm{a})^{*}\end{array}$ \\
\hline Hillslope & & $76.5 \pm 15.3$ & $5.3 \pm 1.2$ & $2.6 \pm 1.6$ & $0.18 \pm 0.11$ \\
\hline $\mathrm{T}_{1}$ tread & $14500 \pm 1500^{1}$ & & & $3.0 \pm 1.8$ & $0.21 \pm 0.13$ \\
\hline $\mathrm{T}_{1}-\mathrm{T}_{2}$ riser & & $41.2 \pm 9.6$ & $6.2 \pm 1.6$ & & \\
\hline $\mathrm{T}_{2}$ tread & $6690 \pm 740$ & & & $1.9 \pm 0.2$ & $0.28 \pm 0.04$ \\
\hline $\mathrm{T}_{2}-\mathrm{T}_{3}$ riser & & $34.5 \pm 7.4$ & $6.3 \pm 1.6$ & & \\
\hline $\mathrm{T}_{3}$ tread & $? 5460 \pm 770^{2}$ & & & $0.7 \pm 0.2$ & $0.13 \pm 0.04$ \\
\hline $\mathrm{T}_{3}-\mathrm{T}_{4}$ riser & & - & - & & \\
\hline $\mathrm{T}_{4}$ tread & $5460 \pm 770^{2}$ & & & - & - \\
\hline $\mathrm{T}_{4}-\mathrm{T}_{5}$ riser & & - & - & & \\
\hline $\mathrm{T}_{5}$ tread & $4000 \pm 1000^{2}$ & & & $-0.5 \pm 0.2$ & $-0.13 \pm 0.06$ \\
\hline $\mathrm{T}_{5}-\mathrm{T}_{6}$ riser & & $9.5 \pm 1.7$ & $4.7 \pm 1.4$ & & \\
\hline $\mathrm{T}_{6}$ tread & $2000 \pm 500^{2}$ & & & $-0.4 \pm 0.1$ & $-0.20 \pm 0.07$ \\
\hline $\mathrm{T}_{6}$ channel & $1172 \pm 111^{3}$ & $6.3 \pm 0.8$ & $5.4 \pm 0.9$ & & $-0.34 \pm 0.09$ \\
\hline
\end{tabular}

Abandonment of $\mathrm{T}_{1}$ at $14.5 \pm 1.5 \mathrm{ka}$ provides a minimum age for offset of the bedrock spur. Combined with the offset of $76.5 \pm 15.3 \mathrm{~m}$, this new OSL age yields a maximum horizontal slip rate of $5.3 \pm 1.2 \mathrm{~mm} / \mathrm{a}$. Displacement of the $\mathrm{T}_{1}$ edge adjacent to the bedrock spur could potentially provide a more accurate slip rate, as it would be expected that this offset would have begun accruing closer in time to the abandonment of the terrace tread. The $\mathrm{T}_{1}$ edge offset of $51.5 \pm 6.3 \mathrm{~m}$ yields a slip rate of $3.6 \pm 0.6 \mathrm{~mm} / \mathrm{a}$ using this age. This estimate should be viewed as a minimum rate, however, as the $T_{1}$ tread has been mantled by colluvium shed from the adjacent hillslope on the north side of the fault, reducing the apparent displacement of this feature. Therefore, the maximum slip rate of $5.3 \pm 1.2 \mathrm{~mm} / \mathrm{a}$ is the preferred value for the new abandonment age of $14.5 \pm 1.5 \mathrm{ka}$. The vertical offset of the hillslope of 2.6 $\pm 1.6 \mathrm{~m}$ yields a north side-up slip rate of $0.2 \pm 0.1 \mathrm{~mm} / \mathrm{a}$, whereas that of the $\mathrm{T}_{1}$ tread of $3.0 \pm 1.8 \mathrm{~m}$ yields a north-up slip rate of $0.21 \pm 0.13 \mathrm{~mm} / \mathrm{a}$. The precision of these 
rates are hindered by: (1) uncertainties in measuring the displacement of the hillslope, and (2) an apparent late-Holocene reversal in the sense of throw on the fault to south-up (discussed below).

Abandonment of $\mathrm{T}_{2}$ at $6.69 \pm 0.74 \mathrm{ka}$ provides the estimated age for accrual of offset of the $\mathrm{T}_{1}-\mathrm{T}_{2}$ riser. When combined with the horizontal offset of $41.2 \pm 9.6 \mathrm{~m}$, this new OSL age yields a maximum slip rate of $6.2 \pm 1.6 \mathrm{~mm} / \mathrm{a}$. The vertical offset of the $T_{2}$ tread of $1.9 \pm 0.2 \mathrm{~m}$ yields a vertical slip rate of $0.3 \pm 0.04 \mathrm{~mm} / \mathrm{a}$. This localised rate must be viewed with caution, however, because of: (1) an apparent late-Holocene reversal in throw that occurred after abandonment of this terrace, and (2) the location of the transpressional pressure ridge uplifting the south side of the fault near the western edge of this tread.

Knuepfer's (1988) weathering rind age of the $\mathrm{T}_{4}$ terrace (his “T3" terrace) of $5.46 \pm 0.77 \mathrm{ka}$ is used here as a minimum age for offset of the $\mathrm{T}_{2}-\mathrm{T}_{3}$ riser. The lateral displacement of this riser of $34.5 \pm 7.4 \mathrm{~m}$ results in a maximum horizontal slip rate of $6.3 \pm 1.6 \mathrm{~mm} / \mathrm{a}$, while vertical displacement of the $T_{3}$ terrace fragment $(0.7 \pm 0.2 \mathrm{~m})$ yields a vertical slip rate of $0.13 \pm 0.04 \mathrm{~mm} / \mathrm{a}$, with the north side upthrown.

Knuepfer's (1988) weathering rind age of the $\mathrm{T}_{5}$ terrace of $4.0 \pm 1.0 \mathrm{ka}$ provides a maximum age for vertical offset of the $\mathrm{T}_{5}$ tread $(0.5 \pm 0.2 \mathrm{~m}$, south side upthrown), and yields a vertical slip rate of $0.13 \pm 0.06 \mathrm{~mm} / \mathrm{a}$. For lateral offset of the $\mathrm{T}_{5}-\mathrm{T}_{6}$ riser, Knuepfer's (1988) age of the $\mathrm{T}_{6}$ terrace of $2.0 \pm 0.5 \mathrm{ka}$ is used, which yields a maximum slip rate of $4.8 \pm 1.5 \mathrm{~mm} / \mathrm{a}$.

McCalpin (1996a) ${ }^{14} \mathrm{C}$ dated silt on top of $\mathrm{T}_{6}$ at $1.172 \pm 0.111 \mathrm{ka}$, which provides a minimum age for horizontal offset of the channel incised into the $\mathrm{T}_{6}$ surface $(6.3 \pm 0.7 \mathrm{~m})$ and vertical offset of the $\mathrm{T}_{6}$ tread $(0.4 \pm 0.1 \mathrm{~m}$, south side upthrown). These yield maximum slip rates of $5.4 \pm 0.9$ and $0.34 \pm 0.1 \mathrm{~mm} / \mathrm{a}$, respectively.

\subsection{DISCUSSION}

\subsubsection{Slip rates of the Molesworth section of the Awatere Fault}

New dating of the Saxton River terraces and GPS-based surveying of terrace offsets allow refined/improved estimates of late Quaternary slip rate to be made for the 

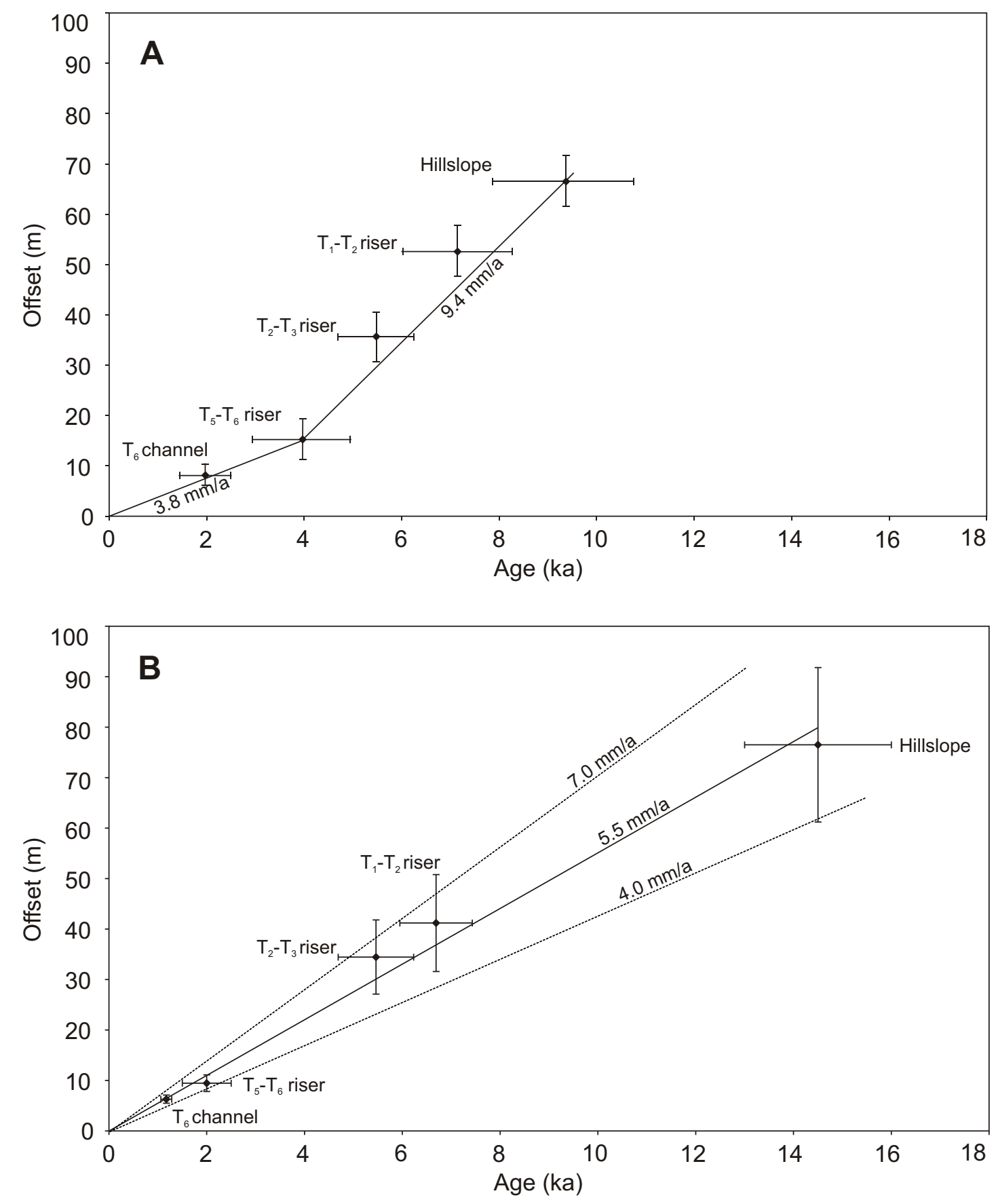

Figure 5.9a-b Plots of individual displaced features (age vs offset) at Saxton River. (A) Pebble weathering rind data as interpreted by Knuepfer (1992), showing an inferred decrease in lateral slip rate at $\sim 4 \mathrm{ka}$. (B) Data from this study, with refined ages of the two oldest terraces showing little or no variation in late Quaternary slip rate. Best-fit lines for these offset and age data suggest a near-constant horizontal slip rate of $5.5 \pm 1.5 \mathrm{~mm} / \mathrm{a}$ since $\sim 14.5 \mathrm{ka}$. 
Molesworth section of the Awatere Fault. Previous work by Knuepfer (1992) suggested two intervals in the late Quaternary over which fault slip rates were quite different (Figure 5.9a). Between 9.4 - 4 ka B.P., he inferred that horizontal displacement accumulated at an average slip rate of $9.4(+11.7,-4.1) \mathrm{mm} / \mathrm{a}$, whereas from $4 \mathrm{ka}$ to the present he inferred horizontal slip at an average rate of $3.8(+2.5$, 1.6) $\mathrm{mm} / \mathrm{a}$. Together, these two periods suggested to him an average slip rate on the fault of 6-7 mm/a since $\sim 10 \mathrm{ka}$ B.P.

The mean slip rate since $14.5 \pm 1.5 \mathrm{ka}$ on the Awatere Fault is calculated here to be a steady $5.5 \pm 1.5 \mathrm{~mm} / \mathrm{a}$. If the OSL ages postdate abandonment of $\mathrm{T}_{1}$ and $\mathrm{T}_{2}$, then the extrapolated abandonment ages of these terraces would decrease this rate. A mean slip rate estimate using these older abandonment ages would be $5.0 \pm 1.2 \mathrm{~mm} / \mathrm{a}$. The uncertainties in both these rate estimates were obtained using the values of maximum and minimum best-fit curves for the individual displacement and dating errors, as shown in Figure 5.9b. Most importantly, this new data show no significant variation in the horizontal slip rates since abandonment of $T_{1}$, predominantly due to the new OSL abandonment age of $\mathrm{T}_{1}$. The previously-documented conspicuous decrease in slip rate at $\sim 4$ ka therefore appears to be an artefact of using too-young pebble weathering rind-based ages to calculate the slip rates. The large underestimation of the age of $T_{1}$ using this dating method, possibly due to a silt cover restricting weathering rind growth, overestimated the early Holocene slip rate. This required two separate line segments to fit the terrace offset data, ultimately resulting in a dramatic, but apparent, slowing of the horizontal slip rate after abandonment of $\mathrm{T}_{5}$ at $4 \mathrm{ka}$ B.P.

\subsubsection{Relationship between paleoseismicity and terrace displacements at Saxton River}

$\underline{\text { Paleoseismicity }}$

The development of a detailed surface rupture chronology from a paleoseismic trench at Saxton River (10 events in $<14.5 \pm 1.5 \mathrm{ka}$; see Chapter 3 ) allows each dated terrace displacement to be attributed to a set of paleoseismically dated coseismic-slip increments. The total displacement for any given terrace riser interval was divided by the number of paleoseismically resolved earthquakes that occurred during that period to obtain a mean coseismic slip magnitude during that 
interval. A graphical depiction of how the paleoseismic record can be related to the terrace offsets is shown in Figure 5.10, where each incremental terrace riser displacement has been subdivided into segments according to the inferred timing of each earthquake observed in the trench. An important caveat for the interpretation of this diagram is to acknowledge an apparent bias in resolution of the earthquake record toward the younger part of the sequence, with a relatively sparse event record older than $\sim 4 \mathrm{ka}$. This bias, if real, would be expected to overestimate the per-event displacement magnitude for the oldest terrace offsets. The two oldest paleoseismically determined rupture events are also not shown on this diagram as their ages are not well constrained (see Chapter 3).

The 10 earthquakes inferred from the trench excavations at Saxton River all occurred after deposition of the $T_{1}$ gravels at $14.5 \pm 1.5 \mathrm{ka}$, which is also the inferred age of the bedrock spur that is dextrally offset by $76.5 \pm 15.3 \mathrm{~m}$ above $T_{1}$. A maximum per-event displacement from this total horizontal displacement would therefore be $\sim 7.7 \pm 1.5 \mathrm{~m}$. This is likely to be a significant overestimate, due to sampling incompleteness and the few recognised events in the trench older than $4 \mathrm{ka}$ B.P.

Total dextral displacement of the $T_{1}-T_{2}$ riser of $41.2 \pm 9.6 \mathrm{~m}$ has accrued during at least the eight youngest surface ruptures, which suggests a maximum perevent displacement of $5.2 \pm 1.2 \mathrm{~m}$. If this displacement has accrued during all ten events identified in the Saxton-2 trench, then a per-event displacement would be 4.1 $\pm 1.0 \mathrm{~m}$. Both of these per-event displacement estimates are comparable in magnitude to observed smallest (metre-scale) geomorphic displacements along both sections of the Awatere Fault. These have been attributed to coseismic slip during the last surface rupturing event (e.g., McCalpin, 1996a; Benson et al., 2001; Chapter 4 , this report).

During the interval from $\mathrm{T}_{2}$ abandonment $(6.69 \pm 0.74 \mathrm{ka})$ to $\mathrm{T}_{3}$ abandonment (5.46 $\pm 0.77 \mathrm{ka})$, one well constrained event occurred. The amount of horizontal displacement that accumulated during this period is $0-24 \mathrm{~m}$, estimated using the maximum differences in offset of the $T_{1}-T_{2}$ and $T_{2}-T_{3}$ risers. It is possible that the oldest two events identified in the trench also occurred during this interval, as the ages of these events are not known. The occurrence of up to three events during this 


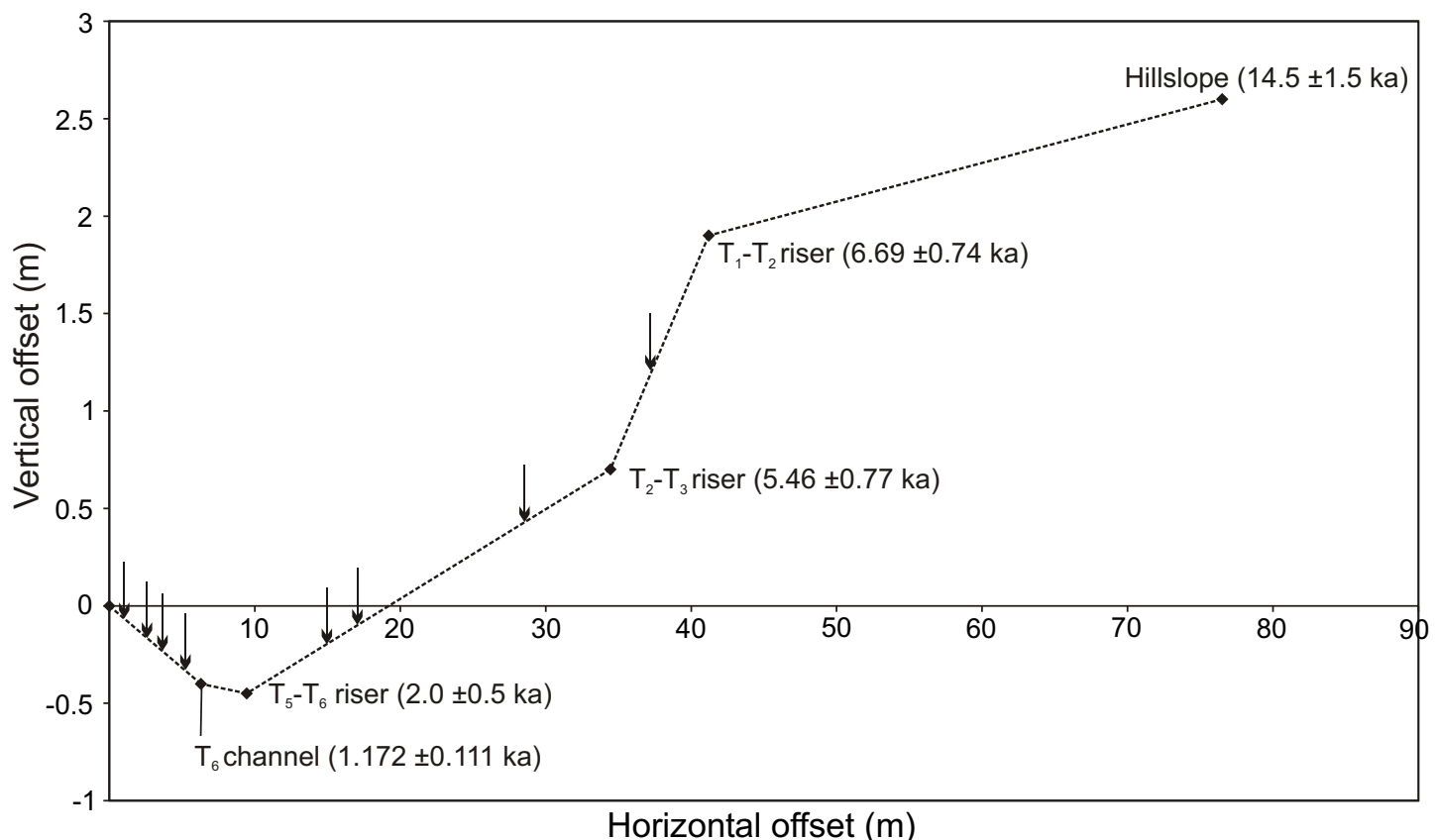

Figure 5.10 Plot of cumulative horizontal and vertical offsets for displaced geomorphic features, east bank, Saxton River. A negative slope for an incremental vertical offset denotes the south side of the fault is upthrown. Also included are approximate ages of earthquakes (small vertical arrows) derived from a paleoseismic trench excavated on $\mathrm{T}_{1}$. These events are placed according to their relative position along each line segment between points of known age (i.e. the individual displacements). 
terrace riser interval implies an average coseismic displacement of 0-8 $\mathrm{m}$. The maximum limit of this estimate is similar in magnitude to the largest metre-scale horizontal displacements that are attributed by McCalpin (1996a) to coseismic slip during individual surface rupturing events.

During the interval from $\mathrm{T}_{3}$ abandonment to the present there are seven recognised surface rupturing events. Total displacement of the $T_{2}-T_{3}$ riser of 34.5 $\pm 7.4 \mathrm{~m}$ implies an average coseismic displacement of $5.0 \pm 1.1 \mathrm{~m}$, similar to result from the displacement of the $\mathrm{T}_{1}-\mathrm{T}_{2}$ riser.

Total displacement of the $\mathrm{T}_{5}-\mathrm{T}_{6}$ riser of $9.5 \pm 1.7 \mathrm{~m}$ has accrued during the four most recent events, a mean per-event displacement of $2.4 \pm 0.4 \mathrm{~m}$. This appears to be less than the 'typical' coseismic slip on the Molesworth section, however, given other paleoseismic data and the abundance of small displacements of 4-6 m (e.g., McCalpin, 1996a). McCalpin (1996a) attributed displacement of the small channel incised into $\mathrm{T}_{6}$ (measured in this study as $6.3 \pm 0.8 \mathrm{~m}$ ) to coseismic slip during only the most recent event, but the new paleoseismic data from Saxton River suggest that this offset accrued during the four surface ruptures that post-date the $T_{5}-T_{6}$ riser, implying a mean per-event displacement of $1.6 \pm 0.2 \mathrm{~m}$. This seems an anomalously small value and suggests McCalpin's ${ }^{14} \mathrm{C}$ age is an overestimate of the actual age of this channel. Alternatively, this channel may have been continuously active during some of these four events, during which time it laterally trimmed the coseismic displacement of its banks.

These incremental displacements yield a mean estimate of $4.4 \pm 0.2 \mathrm{~m}$ of perevent coseismic slip, which is smaller than McCalpin's (1996a) geomorphic measurements of the most recent surface rupture to the west of Saxton River, but is consistent with new measurements made to the east of Saxton River (Chapter 4).

\section{$\underline{\text { Holocene throw reversal }}$}

At Saxton River, previous workers noted a change in the sense of vertical offset during the Holocene, as evidenced by a switch from north-up offset of the $\mathrm{T}_{1} \pm$ $\mathrm{T}_{2}$ surfaces to south-up offset of the younger $\mathrm{T}_{4}-\mathrm{T}_{6}$ surfaces (Knuepfer, 1992; McCalpin, 1996a). Similar patterns of vertical offset were observed on alluvial terraces at Grey River on the eastern section of the Awatere Fault (Lensen, 1964b; 
Little et al., 1998) and elsewhere in the Marlborough fault system (e.g., Lensen, 1968; Knuepfer, 1992). Such a throw reversal on the Awatere Fault seems incongruous given the long-term sense of north-up offset implied by the longwavelength topography along both sections of the Awatere Fault (Little et al., 1998). Similarly, recent work on alluvial terraces near Lake Jasper did not provide evidence for such a reversal during the Holocene (Benson and Little, 2001). As seen in Figure 5.10, the terraces at Saxton River record a late Holocene reversal in the sense of vertical offset that took place after abandonment of $T_{3}$ at $5.46 \pm 0.77 \mathrm{ka}$ (upthrown to the north) and before abandonment of $\mathrm{T}_{6}$ at $1.172 \pm 0.11 \mathrm{ka}$ (upthrown to the south). The $\mathrm{T}_{5}-\mathrm{T}_{6}$ riser on the north side of the fault is $1.3 \mathrm{~m}$ higher than on the south side, implying $T_{5}$ was upthrown to the north during occupation of $T_{6}$ (see Lensen, 1964a), and that south-up displacement since the throw reversal has removed any north-up offset of the tread. If this is true, then the throw reversal must postdate abandonment of $\mathrm{T}_{5}$, and is possibly contemporaneous with abandonment of $\mathrm{T}_{6}$ at $2.0 \pm 0.5 \mathrm{ka}$. Restoring the vertical offsets between the $T_{6}$ tread and the $T_{5}$ tread, however, suggests the $\mathrm{T}_{5}$ tread was upthrown $\sim 0.5 \mathrm{~m}$ to the south at the time $\mathrm{T}_{6}$ was abandoned, inconsistent with the north-up offset implied by the riser height difference. Therefore the uncertain timing of the throw reversal at Saxton River cannot be constrained any narrower than post- $\mathrm{T}_{3}$ and pre- $\mathrm{T}_{6}$ abandonment.

The origins of similar throw reversals documented throughout the Marlborough fault system are contentious. Lensen (1968) noted a reversal in vertical offset at Branch River on the Wairau Fault, and concluded, without any geochronological data, this occurred at the same time to a similar apparent reversal at Grey River on the Awatere Fault (Lensen, 1964b). This apparent synchroneity has been interpreted in terms of a change in the principal horizontal stress across the plate boundary zone in Marlborough (Lensen, 1973), though Knuepfer (1992) disregarded this hypothesis due to strong evidence that throw changes throughout the Marlborough fault system are more likely due to local changes in the geometry of faulting at each individual site. The latter explanation is favoured for the throw reversal at Saxton River. As noted above for the western edge of $\mathrm{T}_{2}$, a $10-15^{\circ}$ change in fault strike has resulted in a change in the upthrown side of the fault here. While this pressure ridge is an exaggerated feature compared to vertical displacement of the adjacent treads, a similar re-orientation is inferred to be responsible for the switch to 
south-side up throw of the youngest terraces. Rapid incision by Saxton River, following the culmination of aggradation of $\mathrm{T}_{2}$, possibly forced a re-orientation of the near-surface fault geometry (e.g., Benson and Little, 2001), resulting in a change in fault-strike across the youngest terraces. While this re-orientation is not directly visible due to the active fault trace being obscured by the Saxton River floodplain, at a larger scale the fault trace does change strike across the Saxton River valley (Figure 5.1).

\subsubsection{Implications of new slip rate estimates for the Awatere Fault and Marlborough fault system}

Slip rates calculated in this study for the Molesworth section of the Awatere Fault show similarities, both in the magnitudes of slip and the apparent lack of variability through the late Quaternary, to recent slip rate estimates for the eastern section of the same fault. Benson et al. (2001) calculated slip rates from faulted alluvial terraces on the eastern section near Lake Jasper, documenting a near-uniform horizontal slip rate of $6 \pm 2 \mathrm{~mm} / \mathrm{a}$ since $\sim 20 \mathrm{ka}$. This is comparable to results from near Upcot Saddle on the eastern section, where strike-slip rates have been calculated that range from $5.6 \pm 1.1 \mathrm{~mm} / \mathrm{a}$ to $8.2 \pm 2.4 \mathrm{~mm} / \mathrm{a}$ since the late Quaternary (see Chapter 2). Slip rates on the Molesworth section at Saxton River also show little variation through the late Quaternary, and the derived average rate of $5.5 \pm 1.5 \mathrm{~mm} / \mathrm{a}$ is similar to the $6 \pm 2 \mathrm{~mm} / \mathrm{a}$ rate determined by Benson et al. (2001) for the eastern section. New mapping of the fault junctions region between the eastern and Molesworth sections, and correlated timing of paleoearthquakes rupturing both sections across the junction provide the basis for the interpretation that the eastern and Molesworth sections of the Awatere Fault may not be independent rupture segments, as previously inferred, but rather two geometric sections of a mechanically contiguous strike-slip fault system (see Chapters 2 and 3). While not a priori evidence for such an hypothesis, the similarities and lack of variation of late Quaternary slip rates observed across the fault junction are consistent with the interpretation that the two fault sections are mechanically linked.

Knuepfer (1992) interpreted a widespread apparent decrease in lateral slip rate across most of the constituent faults of the Marlborough fault system during the Holocene to be an expression of millennial-scale variability in the rates of plate boundary motions through northeast South Island. He argued that variations showed 
a $\sim 5$ ka periodicity, with reliable long-term motions only obtained by averaging incremental slip rates over 15-20 ka (Knuepfer, 1992). As argued above for the Saxton River terraces, dating late Quaternary geomorphic surfaces by pebble weathering rind calibration seems to underestimate the true age of at least the older, pre-Holocene terraces, resulting in a corresponding overestimate of Pleistocene slip rates calculated from the displacements of these surfaces. As this dating technique was used at similar sites throughout the Marlborough fault system by Knuepfer (1992), it is therefore possible that the interpretation of ka-scale variability in plate boundary motions is chiefly an artefact of problems inherent in the pebble weathering rind dating technique. While qualifying such an observation remains outside the limited scope of this study, the refined OSL ages presented here for the Saxton terraces show Knuepfer's (1992) hypothesis could be tested by improved dating at other sites in the Marlborough fault system.

\subsubsection{Climatic implications of new terrace ages}

The morphology and inferred gravel thickness beneath terraces $T_{1}$ and $T_{2}$ suggest these terraces were abandoned and incised following periods of river aggradation, an observation which has implications for the late Quaternary climate history of this area. The new OSL abandonment age of $\mathrm{T}_{1}$ at $14.5 \pm 1.5$ ka provides a minimum age for culmination of the oldest aggradation $\left(T_{1}\right)$ by Saxton River. A refined stratigraphic age of $\mathrm{T}_{1}$ abandonment of $17.7 \pm 5.2 \mathrm{ka}$ is inferred by extrapolating the OSL-age to the terrace tread (see above). These ages suggest Saxton River was aggrading prior to $\sim 17 \mathrm{ka}$, during the Last Glacial Maximum, and consistent with the ages of other major aggradation surfaces in eastern New Zealand (e.g., Berryman et al., 2000; Eden et al., 2001). Importantly, $\mathrm{T}_{1}$ was not abandoned until after the culmination of the main Late Otiran glacial advance at $\sim 18-20$ ka B.P. (Suggate, 1990). The new OSL abandonment age of $\mathrm{T}_{1}$ also coincides with an inferred period of rapid and sustained eustatic sea level rise from 16.0-12.5 ka B.P. (Lambeck et al., 2002). This rise in base-level could possibly provide a mechanism that could have contributed to aggradation of the $T_{1}$ gravels following glacial retreat. Eustatic sea level continued to rise after $T_{1}$ was abandoned and incised, however, suggesting this explanation by itself is insufficient to explain the timing of river aggradation. 
While sea level rise may have contributed to fluvial aggradation and incision at Isolated Flat, this rise in sea level was also accompanied by regional increases in temperature and precipitation (Vandergoes and Fitzsimons, 2003). Such observations suggest a more complete model to explain changes between aggradation and incision by Saxton River. The abandonment age of $T_{1}$ suggests that fluvial aggradation continued into the period of climatic amelioration associated with glacial retreat (Suggate, 1990). Increases in temperature and precipitation associated with this deglaciation possibly removed any permanent snow cover from the catchment headwaters, and caused transportation of a previously "stored" fraction of ice-trapped detritus into the river without allowing it to be transported beyond the transtensional basin at Isolated Flat. This process may have contributed to a marked increase in sediment flux that caused aggradation of the $T_{1}$ gravels, a process similar to that proposed by Townsend (2001) as a forcing mechanism for the continuation of aggradation in parts of coastal Marlborough region to $\sim 10 \mathrm{ka}$ B.P. Continued increases in temperature and precipitation into the Holocene, however, would ultimately force a switch from aggradation to incision, by further increasing the discharge and sediment transport capacity of the river at a time when sediment influx was being reduced as a result of re-establishing vegetation cover within the catchment. The combination of these processes would ultimately trigger incision by Saxton River into the aggradation gravels, leaving an abandoned terrace tread $\left(\mathrm{T}_{1}\right)$.

Such a model would also be reasonable for abandonment of the $T_{2}$ terrace, which represents the culmination of the most recent fluvial aggradation by Saxton River. McCalpin (1992a, 1992b) dated the last major glacial aggradation at Lake Tennyson and in the upper Wairau River valley to have culminated 9.2-9.5 ka B.P. The minimum abandonment age of $\mathrm{T}_{2}$ is $6.69 \pm 0.74 \mathrm{ka}$, provided by an OSL age from overbank silts on the terrace tread, and a maximum age of $9.7 \pm 3.1 \mathrm{ka}$ is estimated by extrapolating this OSL age to the tread (see above). Similar to the case of $\mathrm{T}_{1}$ above, these ages suggest fluvial aggradation persisted well after the glaciers began to retreat. The OSL age of abandonment of $\mathrm{T}_{2}$ corresponds to the time of peak Holocene eustatic sea level (Gibb, 1986; Lambeck et al., 2002), also similar to the relationship observed for $T_{1}$. These observations suggest that the continued, longterm increases in temperature and precipitation during the Holocene ultimately forced regression of the glaciers, releasing upstream repositories of glacial and 
periglacial sediment that had previously accumulated during the glacial advances. Continued increases in precipitation, and possibly glacial meltwater following this Holocene glacial phase, may have increased the sediment transport capacity of Saxton River, resulting in its abandonment and incision into the $\mathrm{T}_{2}$ tread during the mid Holocene.

Incision rates calculated from the ages and relative heights of the Saxton River terraces are consistent with the proposed increase in transport capacity that forced abandonment of $T_{2}$. The mean incision rate from abandonment of $T_{1}$ to the present is $1.4 \pm 0.2 \mathrm{~mm} / \mathrm{a}$. The incremental incision rates between dated terrace tread heights above the modern river, however, show three intervals in the late Quaternary over which fluvial incision has occurred at variable rates (Figure 5.11). During downcutting from $T_{1}$ to $T_{2}$ there was very slow incision $(0.33 \pm 0.06 \mathrm{~mm} / \mathrm{a})$. This is most likely to be a minimum rate, though no suitable exposures exist of the terrace stratigraphy so it is not possible to determine whether abandonment of $\mathrm{T}_{2}$ represents the culmination of a separate 'cut and fill' aggradation event following abandonment of $\mathrm{T}_{1}$, or simply a period of very slow incision. The former implies a variable late Pleistocene climate at Isolated Flat, possibly associated with an early Holocene cooling that facilitated the final glacial advances (e.g., McCalpin, 1992a, 1992b) and fluvial aggradation of $T_{2}$. Abandonment of $T_{2}$ in the mid Holocene was followed by very rapid incision to $\mathrm{T}_{5}(4.7 \pm 1.3 \mathrm{~mm} / \mathrm{a})$, suggesting a very high transport capacity of Saxton River over this interval. Intensification of westerly winds in the mid-late Holocene (e.g., Shulmeister, 1999) is one mechanism that could increase precipitation in the alpine inland Marlborough area at this time, which would have increased the competence of Saxton River. In the latest Holocene, incision from $\mathrm{T}_{5}$ to the present river level has occurred at a mean rate of $1.2 \pm 0.3 \mathrm{~mm} / \mathrm{a}$. 


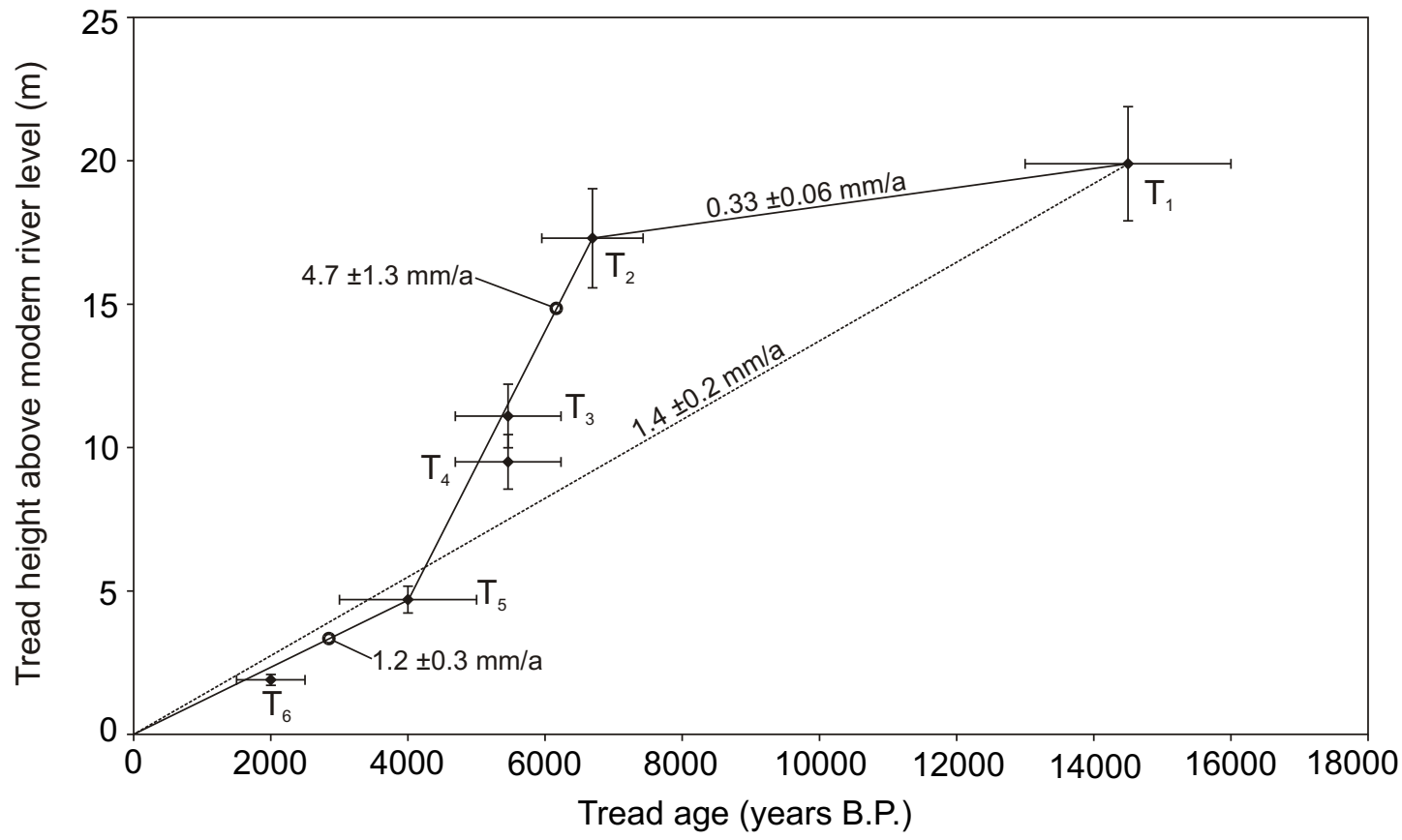

Figure 5.11 Plot of relative terrace tread height against surface age for the Saxton River terraces, used to estimate incremental fluvial incision rates between each terrace tread abandonment. These data show distinct periods over the late Quaternary in which incision rates have fluctuated. The age error bars are those outlined in Table 5.3; the relative height error bars are $\pm 10 \%$, representing the measurement error. 


\subsection{CONCLUSIONS}

New OSL ages of cover sediments on faulted fluvial terraces at Saxton River, in combination with analysis of high-resolution GPS surveys of terrace displacements, significantly refine slip rates on the Molesworth section of the Awatere Fault at this site. These new data constrain progressive fault displacement of the terraces during aggradation and incision to a quasi-constant strike-slip rate of $5.5 \pm 1.5 \mathrm{~mm} / \mathrm{a}$ since $14.5 \pm 1.5 \mathrm{ka}$ B.P. The similarity in magnitude between strike slip rates calculated here for the Molesworth section and recent estimates for the eastern section is consistent with the hypothesis that the two fault sections are kinematically linked across the Mt Chisholm fault junction. Unlike previous studies, no evidence was found for a late Holocene decrease in the rate of strike slip on this fault or for variations in slip rate at the millennial scale. Thus major strike-slip faults in the Marlborough fault system do not appear to accelerate or decelerate on a time scale of $10^{3}$ years.

Vertical slip rates also appear relatively constant at $\sim 0.2 \pm 0.1 \mathrm{~mm} / \mathrm{a}$, though the sense of throw varies from north-up displacement of $T_{1}-T_{4}$ to south-up displacement of $T_{5}$ and $T_{6}$. This throw reversal is constrained to between abandonment of $\mathrm{T}_{3}(>5.46 \pm 0.77 \mathrm{ka})$ and abandonment of $\mathrm{T}_{6}(1.172 \pm 0.111 \mathrm{ka})$. The reversal is most likely not a regional widespread phenomenon, but the result of a local change in the fault strike, possibly forced by rapid fluvial incision following the cessation of aggradation in the early-mid Holocene. It does not appear to be a manifestation of any temporal changes in the principal horizontal stress direction in the Marlborough fault system.

Comparisons between horizontal terrace riser displacements and a detailed surface rupture chronology of the Molesworth section yield a mean coseismic horizontal displacement of $4.4 \pm 0.2 \mathrm{~m}$. The youngest terrace riser displacements are associated with a mean coseismic displacement of $<2 \mathrm{~m}$, which may be due to an apparent late-Holocene increase in earthquake frequency. Comparisons between horizontal terrace riser displacements and fault-parallel tread widths suggest Saxton River completely trimmed any coseismic displacements of the river banks following surface-rupturing earthquakes. 
The new OSL age of abandonment of $T_{1}$ suggests significant fluvial aggradation took place between the Last Glacial Maximum and $14.5 \pm 1.5 \mathrm{ka}$, synchronous with sea level rise and a regional increase in precipitation. This possibly increased the flow capacity of Saxton River sufficiently to transport upstream repositories of glacial and periglacial sediment that had previously accumulated during the Last Glacial Maximum. A large apparent hiatus between abandonment of $T_{1}$ and $T_{2}$, and a contemporaneous re-advance of glaciers in this region, suggest incision into $T_{1}$ was followed by a separate aggradational pulse that deposited the $\mathrm{T}_{2}$ gravel. Since abandonment of $\mathrm{T}_{2}$ at $6.69 \pm 0.74 \mathrm{ka}$, Saxton River has incised into the $T_{1}$ and $T_{2}$ alluvium. Fluvial incision rates by Saxton River in the late Quaternary are non-uniform, ranging from $0.33 \pm 0.06 \mathrm{~mm} / \mathrm{a}$ in the late Pleistocene to $4.7 \pm 1.3 \mathrm{~mm} / \mathrm{a}$ following abandonment of $\mathrm{T}_{2}$. Rapid incision during the late Holocene suggests an increase in the transport capacity of Saxton River that was possibly forced by regional increases in precipitation and vegetation cover in the drainage catchment. 


\section{Conclusions}

The results of this detailed study refine our understanding of the location, geometry, and kinematics of a major junction between two geometrical sections of the Awatere Fault. The intersection between the Molesworth and eastern sections is $\sim 1.2 \mathrm{~km}$ southwest of Kennet River, west of which the two sections diverge at an angle of $10-15^{\circ}$. The fault junctions region between the two fault sections comprises an elongate, internally faulted wedge that is $\sim 15 \mathrm{~km}$ long and up to $3 \mathrm{~km}$ wide at its western end. The faults within this block are spaced $10-10^{3} \mathrm{~m}$ apart, and form angles of up to $30^{\circ}$ clockwise from the principal faults. Observations of modern global earthquake ruptures suggest fault bends greater than $30^{\circ}$, and step-overs wider than 5 $\mathrm{km}$, arrest rupture propagation whereas those less than $30^{\circ}$ or $5 \mathrm{~km}$ do not. The lowangle, narrow junction between the eastern and Molesworth sections therefore appears unlikely to impede or arrest some rupture propagation, and implies that eastern and Molesworth sections of the Awatere Fault may rupture simultaneously during large magnitude earthquakes.

This interpretation is consistent with new paleoseismic data from four trenches excavated on each side of the junction between these two faults. Stratigraphic evidence from a new paleoseismic trench at Saxton River, $18 \mathrm{~km}$ to the west of the fault junctions region on the Molesworth section of the Awatere Fault, indicates there have been up to ten surface-rupturing paleoearthquakes since 14.5 $\pm 1.5 \mathrm{ka}$ B.P. at that site. Stratigraphic evidence from two new paleoseismic trenches excavated near Upcot Saddle, $\sim 12 \mathrm{~km}$ to the northeast of the fault junctions region on the eastern section, indicate that there have been up to five paleoearthquakes since 5310-5600 cal. years B.P. at this site, including a very young event $(<300$ cal. years B.P.) that is inferred to be the $1848 \mathrm{M}_{\mathrm{w}} \sim 7.5$ Marlborough earthquake. Nine events since $8330-8610$ cal. years B.P. are identified for the entire eastern section by combining the surface rupture chronologies from the Upcot Saddle trenches with a detailed earthquake chronology from two trenches excavated at Lake Jasper, $55 \mathrm{~km}$ to the northeast. The age ranges of five surface rupturing events on the eastern section, including the 1848 Marlborough earthquake, are statistically indistinct (at $95 \%$ confidence) from events on the Molesworth section at 5750-6180, 4250-4600, 
3000-3500, 930-1180 and 0-310 cal. years B.P. The apparent coincidence in the timing of these earthquakes suggests that large earthquakes have possibly ruptured both fault strands simultaneously, and that the fault section junction has not always acted as an effective barrier to rupture propagation. Alternatively, at least some of these closely-timed events may have been separate events that occurred within a time period narrower than the resolution provided by radiocarbon dating.

Metre-scale displacements of geomorphic features along the eastern section of the Awatere Fault indicate the 1848 earthquake ruptured at least $100-110 \mathrm{~km}$ of the eastern section's surface trace, with mean horizontal displacement of $5.3 \pm 1.6 \mathrm{~m}$. These data yield a new moment magnitude estimate of $\mathrm{M}_{\mathrm{w}}=7.4-7.7$ for that earthquake, which compares favourably to previous estimates based on felt intensities assigned using historical accounts. If the eastern and Molesworth sections ruptured simultaneously in 1848, as is consistent with neotectonic and paleoseismic data from the fault junction region, then the smallest geomorphic displacements on the Molesworth section would be attributable to the 1848 earthquake. Combined with those on the adjacent eastern section, this would imply a local cumulative-slip maximum of $8.1 \pm 2.0 \mathrm{~m}$ in the vicinity of the fault junctions region and increasing the mean coseismic slip estimate for this earthquake to $5.8 \pm 2.0 \mathrm{~m}$. Similarly, the surface area of rupture would extend westward along the Molesworth section at least as far as Saxton River; however, this would not affect the estimated rupture length of 100-110 km. If a cumulative-slip maximum did occur near the fault junctions region, then this suggests that the rupture nucleated near that region, and that this geometrical complexity has acted as a preferred site for the nucleation of very large $\left(\mathrm{M}_{\mathrm{w}}>7.5\right)$ earthquakes.

Slip rates on the Molesworth section of the Awatere Fault have been revised by new OSL ages of cover sediments on faulted fluvial terraces at Saxton River, in combination with analysis of high-resolution GPS surveys of terrace displacements. Progressive fault displacement of the terrace risers since $14.5 \pm 1.5$ ka B.P. has accumulated at a near-constant mean rate of $5.5 \pm 1.5 \mathrm{~mm} / \mathrm{a}$. Unlike previous studies, no evidence was found for a late Holocene decrease in the rate of strike slip on this fault, or for variations in slip rate at the millennial scale. The rate of late Quaternary strike-slip on the eastern section has been $6 \pm 2 \mathrm{~mm} / \mathrm{a}$ since the Last Glacial Maximum. The similarities in slip rates between the eastern and Molesworth 
sections are consistent with the hypothesis that the two fault sections have been kinematically well-linked across the fault junction region in the late Quaternary. The new OSL ages of the Saxton River terraces also record two phases of fluvial aggradation post-dating the Last Glacial Maximum.

A prominent topographic lineament of notches that are incised into bedrock spurs was mapped as the surface expression of the southwestern-most eastern section trace in the Guide River catchment. These notches are traceable to within $\sim 500 \mathrm{~m}$ of the Clarence Fault, suggesting the Awatere Fault may join with the Clarence Fault across a narrow $\left(10-30^{\circ}\right)$ fault intersection near the confluence of the Guide and Acheron Rivers. 


\section{REFERENCES}

Aki, K. 1984: Asperities, barriers, characteristic earthquakes and strong motion prediction. Journal of Geophysical Research 89 (B7): 5867-5872.

Anderson, H. J., Webb, T. H., Jackson, J. 1993: Focal mechanisms of large earthquakes in the South Island of New Zealand: Implications for the accommodation of Pacific-Australia plate motion. Geophysical Journal International 115 (3): 103-1054.

Anderson, J. G., Wesnousky, S. G., Stirling, M. W. 1996: Earthquake size as a function of fault slip rate. Bulletin of the Seismological Society of America 86 (3): 683-690.

Baker, J. A., Gamble, J. A., Graham, I. J. 1994: The age, geology, and geochemistry of the Tapuaenuku Igneous Complex, Marlborough, New Zealand. New Zealand Journal of Geology and Geophysics 37: 249-268.

Barka, A. A., Akyuz, H. S., Altunel, E., Sunal, G., Cakir, Z., Dikbas, A., Yerli, B., Armijo, R., Meyer, B., de Chabalier, J. B., Rockwell, T. K., Dolan, J. R., Hartleb, R. D., Dawson, T. E., Christofferson, S., Tucker, A. Z., Fumal, T., Langridge, R., Stenner, H., Lettis, W., Bachhuber, J., Page, W. D. 2002: The surface rupture and slip distribution of the 17 August 1999 Izmit earthquake (M 7.4), north Anatolian Fault. Bulletin of the Seismological Society of America 92 (1): 43-60.

Barka, A. A. and Kadinsky-Cade, K. 1988: Strike-slip fault geometry in Turkey and its influence on earthquake activity. Tectonics 7 (3): 663-684.

Benson, A. M. and Little, T. A. 2001: Temporal and spatial variability of Late Quaternary slip on the Awatere Fault. New Zealand Earthquake Commission Research Report 97/262. Wellington, New Zealand: 2.1-2.40.

Benson, A. M., Little, T. A., Van Dissen, R. J., Hill, N., Townsend, D. B. 2001: Late Quaternary paleoseismic history and surface rupture characteristics of the eastern Awatere strike-slip fault. Geological Society Of America Bulletin 113: 1079-1091.

Berryman, K. R., Marden, M., Eden, D. N., Mazengarb, C., Ota, Y., Moriya, I. 2000: Tectonic and paleoclimatic significance of Quaternary river terraces of the Waipaoa River, east coast, North Island, New Zealand. New Zealand Journal of Geology and Geophysics 43 (2): 229-245.

Biasi, G. P. and Weldon II, R. J. 1994: Quantitative refinement of calibrated 14C distributions. Quaternary Research 41 (1): 1-18.

Biasi, G. P., Weldon II, R. J., Fumal, T. E., Seitz, G. G. 2002: Paleoseismic event dating and the conditional probability of large earthquakes on the southern San Andreas fault, California. Bulletin of the Seismological Society of America 92 (7): 2761-2781.

Boggs, S. 1995: Principles of sedimentology and stratigraphy. New Jersey, USA, Prentice-Hall Inc: $774 \mathrm{pp}$.

Bonilla, M. G., Mark, R. K., Lienkaemper, J. J. 1984: Statistical relations among earthquake magnitude, surface rupture length, and surface fault displacement. Bulletin of the Seismological Society of America 74: 2379-2441. 
Bowen, D. Q. 1978: Quaternary Geology. Oxford, England, Permagon Press: 221 pp.

Carter, L., Lewis, K. B., Davey, F. 1988: Faults in Cook Strait and their bearing on the structure of central New Zealand. New Zealand Journal of Geology and Geophysics 31 (4): 431-446.

Chinn, T. J. H. 1981: Use of rock weathering-rind thickness for Holocene absolute age-dating in New Zealand. Arctic and Alpine Research 13 (1): 33-45.

Cowan, H. A. 1991: The North Canterbury earthquake of September 1, 1888. Journal of the Royal Society of New Zealand 21: 1-12.

De Mets, C., Gordon, R. G., Argus, D. F., Stein, S. 1990: Current plate motions. Geophysical Journal International 101: 425-478.

De Mets, C., Gordon, R. G., Argus, D. F., Stein, S. 1994: Effect of recent revisions to the geomagnetic reversal time scale on estimates of current plate motions. Geophysical Research Letters 21 (20): 2191-2194.

Doser, D. I. and Robinson, R. 2002: Modeling stress changes induced by earthquakes in the southern Marlborough region, South Island, New Zealand. Bulletin of the Seismological Society of America 92 (8): 3229-3238.

Dowrick, D. J. submitted: The magnitude of the 1848 October 16 Marlborough, New Zealand, earthquake. New Zealand Journal of Geology and Geophysics.

Dowrick, D. J. and Rhoades, D. A. 1999: Attenuation of Modified Mercalli intensity in New Zealand earthquakes. Bulletin of the New Zealand Society for Earthquake Engineering 32 (2): 55-89.

Dowrick, D. J. and Rhoades, D. A. in press: Relations between earthquake magnitude and fault rupture dimensions - how regionally variable are they? Bulletin of the Seismological Society of America.

Eden, D. N. 1989: River terraces and their loessial cover beds, Awatere River valley, South Island, New Zealand. New Zealand Journal of Geology and Geophysics 32: 487-497.

Eden, D. N., Palmer, A. S., Cronin, S. J., Marden, M., Berryman, K. R. 2001: Dating the culmination of river aggradation at the end of the last glaciation using distal tephra compositions, eastern North Island, New Zealand. Geomorphology 38: 133-151.

Eiby, G. A. 1980: The Marlborough earthquakes of 1848. New Zealand Department of Scientific and Industrial Research Bulletin 225: $82 \mathrm{p}$.

Gibb, J. G. 1986: A New Zealand regional Holocene eustatic sea level curve and its application to determination of vertical tectonic movements. A contribution to IGCP-Project 200. Royal Society of New Zealand Bulletin 24: 377-395.

Grant, L. B. and Sieh, K. 1994: Paleoseismic evidence of clustered earthquakes on the San Andreas fault in the Carrizo Plain, California. Journal of Geophysical Research 99 (B4): 6819-6841.

Grapes, R. H. 1999: Geomorphology of faulting: The Wairarapa Fault, New Zealand. Annals of Geomorphology Supplement 115: Proceedings of the Fourth International Conference on Geomorphology, Bologna, 1997, vII: 191-217.

Grapes, R. H., Lamb, S. H., Adams, C. J. 1992: K-Ar ages of basantic dikes, Awatere Valley, Marlborough, New Zealand. New Zealand Journal of Geology and Geophysics 35: 415-419. 
Grapes, R. H., Little, T. A., Downes, G. L. 1998: Rupturing of the Awatere Fault during the 1848 October 16 Marlborough earthquake, New Zealand: historical and present day evidence. New Zealand Journal of Geology and Geophysics 41: 387-399.

Grapes, R. H. and Wellman, H. W. 1986: The north-east end of the Wairau Fault, Marlborough, New Zealand. Journal of the Royal Society of New Zealand 16 (3): 245-250.

Hanks, T. C. and Bakun, W. H. 2002: A bilinear source-scaling model for M-log A observations of continental earthquakes. Bulletin of the Seismological Society of America 92: 1841-1846.

Hanks, T. C. and Kanamori, H. 1979: A moment magnitude scale. Journal of Geophysical Research 84: 2348-2350.

Harris, R. A. and Day, S. M. 1993: Dynamics of fault interaction: Parallel strike-slip faults. Journal of Geophysical Research 98 (B3): 4461-4472.

Hartleb, R., Dolan, J. F., Akyuz, H. S., Dawson, T. E., Tucker, A. Z., Yerli, B., Rockwell, T. K., Toraman, E., Cakir, Z., Dikbas, A., Altunel, E. 2002: Surface rupture and slip distribution along the Karadere segment of the 17 August 1999 Izmit and the western section of the 12 November 1999 Duzce, Turkey, earthquakes. Bulletin of the Seismological Society of America 92 (1): 67-78.

Hemphill-Haley, M. A. and Weldon II, R. J. 1999: Estimating prehistoric earthquake magnitude from point measurements of surface rupture. Bulletin of the Seismological Society of America 89 (5): 1264-1279.

Hill, N., Little, T. A., Van Dissen, R. J., Benson, A. M., Townsend, D. B., McLea, B. 2001: A refined paleoseismic history of the eastern section of the Awatere Fault, New Zealand, based on results from a 2nd trench excavated near Lake Jasper. New Zealand Earthquake Commission Research Report 97/262. Wellington: 4.1-4.19.

Holt, W. E. and Haines, H. J. 1995: The kinematics of northern South Island New Zealand, determined from geologic strain rates. Journal of Geophysical Research 100: 17,991-18,010.

Kieckhefer, R. M. 1979: Sheets M31D, N31A, N31C and pts M32A \& M32B, Leader Dale (1st edition); Sheets N31B \& N31D, Dillon (1st edition); Sheets O30C \& O31A, Lake McRae (1st edition). Late Quaternary Tectonic Map of New Zealand 1:50 000. Department of Scientific and Indutstrial Research, Wellington, New Zealand.

King, G. and Nabelek, J. 1985: Role of fault bends in the initiation and termination of earthquake rupture. Science 228: 984-987.

Knuepfer, P. L. K. 1988: Estimating ages of late quaternary stream terraces from analysis of weathering rinds and soils. Geological Society Of America Bulletin 100 (8): 1224-1236.

Knuepfer, P. L. K. 1992: Temporal variations in latest Quaternary slip across the Australian-Pacific plate boundary, north-eastern South Island, New Zealand. Tectonics 11: 449-464.

Lambeck, K., Yokoyama, Y., Purcell, T. 2002: Into and out of the Last Glacial Maximum: sea-level change during Oxygen Isotope Stages 3 and 2. Quaternary Science Reviews 21:343-360.

Langridge, R. M. 2000: How is tectonic slip partitioned from the Alpine Fault to the Marlborough Fault System? Geological Society of New Zealand Miscellaneous Publication 108A. 
Langridge, R. M., Stenner, H. D., Fumal, T. E., Christofferson, S. A., Rockwell, T. K., Hartleb, R. D., Bachhuber, J., Barka, A. A. 2002: Geometry, slip distribution, and kinematics of surface rupture on the Sakarya fault segment during the 17 August 1999 Izmit, Turkey, earthquake. Bulletin of the Seismological Society of America 92 (1): 107-125.

Lensen, G. J. 1963: Sheet 16, Kaikoura. Geological Map of New Zealand 1:250 000. Department of Scientific and Indutstrial Research, Wellington, New Zealand.

Lensen, G. J. 1964a: The general case of progressive fault displacement of flights of degradational terraces. New Zealand Journal of Geology and Geophysics 7: 864-870.

Lensen, G. J. 1964b: The faulted terrace sequence at the Grey River, Awatere Valley, South Island, New Zealand. New Zealand Journal of Geology and Geophysics 7: 871-876.

Lensen, G. J. 1968: Analysis of progressive fault displacement during downcutting at the Branch River terraces, South Island, New Zealand. Geological Society Of America Bulletin 79: 545556.

Lensen, G. J. 1973: Guidebook for excursion A10. Field Trip Guide, Ninth Congress, International Union for Quaternary Research, Christchurch, New Zealand, 76 pp.

Leopold, L. B., Wolman, M. G., Miller, J. P. 1964: Fluvial Processes in Geomorphology. San Francisco, USA, W. H. Freeman: 522 pp.

Lettis, W., Bachhuber, J., Witter, R., Brankman, C., Randolph, C. E., Barka, A. A., Page, W. D., Kaya, A. 2002: Influence of releasing step-overs on surface rupture and fault segmentation: Examples from the 17th August, 1999 Izmit Earthquake on the North Anatolian Fault, Turkey. Bulletin of the Seismological Society of America 92 (1; 3): 19-42.

Lewis, K. B. and Pettinga, J. R. 1993: The emerging, imbricate frontal wedge of the Hikurangi Margin. In: Ballance, P. F. (eds.) South Pacific Sedimentary Basins. Amsterdam, Elsevier Science: $225-250$.

Little, T. A., Grapes, R. H., Berger, G. W. 1998: Late Quaternary strike-slip on the eastern part of the Awatere Fault, South Island, New Zealand. Geological Society Of America Bulletin 110: 127148.

Little, T. A. and Jones, A. 1998: Seven million years of strike-slip and off-fault deformation on the Awatere Fault, South Island, New Zealand. Tectonics 17: 285-302.

Little, T. A. and Roberts, A. P. 1997: Distribution and mechanism of Neogene to Present-day verticalaxis rotations, Pacific-Australia plate boundary zone, South Island, New Zealand. Journal of Geophysical Research 102 (B9): 20,447-20,468.

Machette, M. N., Personius, S. F., Nelson, A. R., Schwartz, D. P., Lund, W. R. 1991: The Wasatch fault zone, Utah - segmentation and history of Holocene earthquakes. Journal of Structural Geology 13 (2): 137-149.

MacKinnon, T. C. 1983: Origin of the Torlesse terrane and coeval rocks, South Island, New Zealand. Geological Society Of America Bulletin 94: 967-985.

McCalpin, J. P. 1992a: Glacial and post-glacial geology near Lake Tennyson, Clarence River, New Zealand. New Zealand Journal of Geology and Geophysics 35: 201-210. 
McCalpin, J. P. 1992b: Glacial geology of the upper Wairau Valley, Marlborough, New Zealand. New Zealand Journal of Geology and Geophysics 35: 211-222.

McCalpin, J. P. 1996a: Tectonic geomorphology and Holocene paleoseismicity of the Molesworth section of the Awatere Fault, South Island, New Zealand. New Zealand Journal of Geology and Geophysics 39: 33-50.

McCalpin, J. P., Ed. 1996b: Paleoseismology. San Diego, Academic Press: 583 pp.

McLean, G. W. 1986: Structure and metamorphism near the Alpine and Awatere Faults, Lewis Pass. M. Sc. thesis, University of Canterbury, New Zealand: 156 pp.

McSaveney, M. J. 1992: A manual for weathering-rind dating of grey sandstones of the Torlesse Supergroup, New Zealand. New Zealand Institute of Geological and Nuclear Sciences Science Report 92/4. Wellington, New Zealand: 52 pp.

Merritts, D. J., Vincent, K. R., Wohl, E. E. 1994: Long river profiles, tectonism and eustasy: A guide to interpreting fluvial terraces. Journal of Geophysical Research 99 (B7): 14031-14050.

Miall, A. D. 1992: Alluvial deposits. In: Walker, R. G. and James, N. P. (eds.) Facies models response to sea level change. Ontario, Canada, Geological Association of Canada: 454 pp.

Molnar, P., Brown, E. T., Burchfiel, B. C., Qidong, D., Xianyue, F., Jun, L., Raisbeck, G. M., Jianbang, S., Zhangming, W., Yiou, F., Huichuan, Y. 1994: Quaternary climate change and the formation of river terraces across growing anticlines on the north flank of the Tien Shan, China. Journal of Geology 102: 583-602.

Newnham, R. M., Eden, D. N., Lowe, D. J., Hendy, C. H. 2003: Rerewhakaaitu Tephra, a land-sea marker for the last termination in New Zealand, with implications for global climate change. Quaternary Science Reviews 22: 289-308.

Nicol, A. and Van Dissen, R. J. 2002: Up-dip partitioning of displacement components on the oblique-slip Clarence Fault, New Zealand. Journal of Structural Geology 24: 1521-1535.

Ouchi, S. 1985: Response of alluvial rivers to slow active tectonic movement. Geological Society Of America Bulletin 96: 504-515.

Pillans, B., McGlone, M. S., Palmer, A. S., Mildenhall, D. C., Alloway, B., Berger, G. W. 1993: The Last Glacial Maximum in central and southern North Island, New Zealand: A paleoenvironmental reconstruction using the Kawakawa Tephra Formation as a chronostratigraphic marker. Palaeogeography, Palaeoclimatology, Palaeoecology 101: 283-304.

Ramsey, C. B. 1995: Radiocarbon Calibration and Analysis of Stratigraphy: The OxCal Program. Radiocarbon 37 (2): 425-430.

Ramsey, C. B. 2003: OxCal v3.9. http//www.rlaha.ox.ac.uk/orau/oxcal.html. Last visited 4/01/04.

Rieser, U. 2002: Determination of sediment deposition ages by luminescence dating. School of Earth Sciences Technical Report No. 02/5. Victoria University of Wellington, New Zealand.

Rockwell, T. K., Keller, E. A., Clark, M. N., Johnson, D. L. 1984: Chronology and rates of faulting of Ventura River terraces, California. Geological Society Of America Bulletin 95: 1466-1474.

Rockwell, T. K., Lindvall, S., Herzberg, M., Murbach, D., Dawson, T., Berger, G. W. 2000: Paleoseismology of the Johnson Valley, Kickapoo, and Homestead Valley Faults: Clustering of 
earthquakes in the Eastern California Shear Zone. Bulletin of the Seismological Society of America 90 (5): 1200-1236.

Rubin, C. M. 1996: Systematic underestimation of earthquake magnitudes from large intracontinental reverse faults: Historical ruptures break across segment boundaries. Geology 24 (11): 989-992.

Schwartz, D. P. and Coppersmith, K. J. 1984: Fault behaviour and characteristic earthquakes: Examples from the Wasatch and San Andreas fault zones. Journal of Geophysical Research 89 (B7): 5681-5698.

Shulmeister, J. 1999: Australasian evidence for mid-Holocene climate change implies prescessional control of Walker circulation in the Pacific. Quaternary International 57-58: 81-91.

Shulmeister, J. and Grapes, R. H. 2000: Gravel aggradation during interglaciations: Implications from Palliser Bay, southern North Island, New Zealand. Geological Society of New Zealand Miscellaneous Publication 108A.

Sibson, R. H. 1986: Rupture interaction with fault jogs. In: Das, S., Boatwright, J. and Scholz, C. H. (eds.) Earthquake Source Mechanics. Washington, D.C., American Geophysical Union. Geophysical Monograph 37: 157-167.

Sieh, K., Jones, L., Hauksson, E., Hudnut, K., Eberhart-Philips, D., Heaton, T., Hough, S., Hutton, K., Kanamori, H., Lije, A., Lindvall, S., McGill, S. F., Mori, J., Rubin, C., Spotila, J. A., Stock, J., Thio, H. K., Treiman, J., Wernicke, B. P., Zachariasen, J. 1993: Near-field investigations of the Landers earthquake sequence, April to July 1992. Science 260: 171-176.

Spotila, J. A. and Sieh, K. 1995: Geologic investigations of a "slip gap" in the surficial ruptures of the 1992 Landers earthquake, southern California. Journal of Geophysical Research 100 (B1): 543559.

Stein, R. S. 1999: The role of stress transfer in earthquake occurrence. Nature 402: 605-609.

Stein, R. S., Barka, A., Dieterich, J. H. 1997: Progressive failure on the north Anatolian fault since 1939 by earthquake stress triggering. Geophysical Journal International 128: 594-604.

Stirling, M. W., McVerry, G. H., Berryman, K. R. 2002a: A new seismic hazard model for New Zealand. Bulletin of the Seismological Society of America 92 (5): 1878-1903.

Stirling, M. W., Rhoades, D. A., Berryman, K. R. 2002b: Comparison of earthquake scaling relations derived from data of the instrumental and preinstrumental era. Bulletin of the Seismological Society of America 92 (2): 812-830.

Stuiver, M., Reimer, P. J., Bard, E., Beck, J. W., Burr, G. S., Hughen, K. A., Kromer, B., McCormac, F. G., van der Plicht, J., Spurk, M. 1998: INTCAL98 radiocarbon age calibration, 24,000-0 cal BP. Radiocarbon 40: 1041-1083.

Suggate, R. P. 1990: Late Pliocene and Quaternary glaciations of New Zealand. Quaternary Science Reviews 9: 175-197.

Suggate, R. P., Gair, H. S., Gregg, D. R. 1961: The south-west extension of the Awatere Fault. New Zealand Journal of Geology and Geophysics 4: 264-269.

Townsend, D. B. 2001: Neogene evolution of the Pacific-Australia plate boundary zone in NE Marlborough, South Island, New Zealand. Ph. D. thesis, Victoria University of Wellington, New Zealand: 186 p. 
Vandergoes, M. J. and Fitzsimons, S. J. 2003: The Last Glacial-Interglacial Transition (LGIT) in south Westland, New Zealand: Paleoecological insight into mid-latitude Southern Hemisphere climate change. Quaternary Science Reviews 22 (14): 1461-1476.

Vella, P., Kaewyana, W., Vucetich, C. G. 1988: Late Quaternary terraces and their cover beds, northwestern Wairarapa, New Zealand, and provisional correlations with oxygen isotope stages. Journal of the Royal Society of New Zealand 18 (3): 309-324.

Walcott, R. I. 1998: Modes of oblique compression: Late Cenozoic tectonics of the South Island of New Zealand. Reviews of Geophysics 36 (1): 1-26.

Wellman, H. W. 1953: Data for the study of recent and late Pleistocene faulting in the South Island of New Zealand. New Zealand Journal of Science and Technology 34: 270-288.

Wells, D. L. and Coppersmith, K. J. 1994: New empirical relationships among magnitude, rupture length, rupture width, rupture area, and surface displacement. Bulletin of the Seismological Society of America 84 (4): 974-1002.

Zachariasen, J. and Sieh, K. 1995: The transfer of slip between two en echelon strike-slip faults: A case study from the 1992 Landers earthquake, southern California. Journal of Geophysical Research 100 (B8): 15281-15301. 


\section{APPENDIX A. GEOMORPHIC LANDFORMS DISPLACED BY THE AWATERE FAULT IN THE UPPER AWATERE AND ACHERON RIVER VALLEYS}

Table A.1. Fault displacements measured along the eastern section of the Awatere Fault, from Grey River southwest to Barefell Pass in the upper Awatere Valley, and along the Molesworth section of the fault from Isolated Flat northeast to Kennet River. The fault displaces stream channels, bedrock spurs, alluvial terrace risers, alluvial fan treads, hillslopes and other geomorphic features in these areas. Offsets were measured at 97 sites for this study; also included are three terrace riser displacements measured by Little et al. (1998).

\begin{tabular}{|c|c|c|c|c|c|c|c|c|c|c|c|}
\hline Site & Easting & Northing & 立 & $\begin{array}{l}\text { Fault } \\
\text { strike }\end{array}$ & $\begin{array}{c}\text { Offset } \\
\text { feature }\end{array}$ & 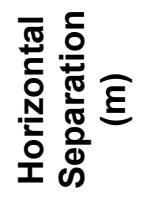 & 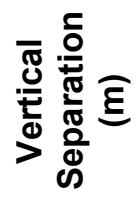 & 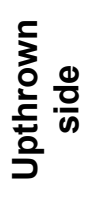 & 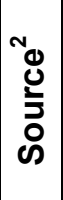 & 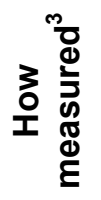 & Notes \\
\hline 1 & 2520738 & 5901103 & $\mathrm{M}$ & 076 & channel & $35.2 \pm 2.5$ & $4.5 \pm 1.5$ & nw & 1 & tape & Ephemeral channel incised into alluvial fan surface \\
\hline 2 & 2521987 & 5892199 & $\mathrm{E}$ & 019 & spur & $7.8 \pm 1.8$ & & & 1 & tape & \\
\hline 3 & 2522543 & 5901760 & $\mathrm{M}$ & 060 & channel & $6.3 \pm 0.8$ & $0.4 \pm 0.1$ & se & 1 & gps & Ephemeral channel incised into $\mathrm{T}_{6}$ surface, Saxton River \\
\hline 4 & 2522655 & 5901827 & $\mathrm{M}$ & 058 & terrace & $9.5 \pm 1.7$ & $0.5 \quad \pm 0.2$ & se & 1 & gps & $T_{5}-T_{6}$ alluvial terrace riser, Saxton River \\
\hline 5 & 2522752 & 5901891 & M & 058 & terrace & $34.5 \pm 7.4$ & $0.7 \pm 0.2$ & nw & 1 & gps & $\mathrm{T}_{2}-\mathrm{T}_{3}$ alluvial terrace riser, Saxton River \\
\hline 6 & 2523020 & 5893736 & $\mathrm{E}$ & 021 & channel & $4.8 \pm 1.2$ & & & 1 & tape & Deflected channel near Barefell Pass; ?single event \\
\hline 7 & 2523046 & 5901968 & $\mathrm{M}$ & 066 & terrace & $41.2 \pm 9.6$ & $1.9 \pm 0.2$ & $\mathrm{nw}$ & 1 & gps & $T_{1}-T_{2}$ alluvial terrace riser, Saxton River \\
\hline 8 & 2523365 & 5902018 & $\mathrm{M}$ & 074 & spur & $51.5 \pm 6.3$ & $3 \pm 1.8$ & nw & 1 & gps & $T_{1}$ alluvial terrace edge, Saxton River \\
\hline 9 & 2523427 & 5894970 & $\mathrm{E}$ & 064 & channel & $10.8 \pm 2.4$ & $3.8 \pm 1.8$ & $\mathrm{nw}$ & 1 & tape & Ephemeral channel; maximum displacement \\
\hline 10 & 2523443 & 5902040 & $\mathrm{M}$ & 081 & spur & $76.5 \pm 15.3$ & $2.6 \pm 1.6$ & nw & 1 & gps & Displaced spur, Saxton River \\
\hline 11 & 2523481 & 5894963 & $\mathrm{E}$ & 064 & channel & $8 \pm 1.6$ & $3.4 \pm 1.8$ & $\mathrm{nw}$ & 1 & tape & Ephemeral channel; maximum displacement \\
\hline 12 & 2523745 & 5902156 & $\mathrm{M}$ & 068 & channel & $2.2 \pm 0.4$ & & & 1 & tape & Ephemeral channel; ?single event \\
\hline 13 & 2523745 & 5902156 & $\mathrm{M}$ & 068 & channel & $8.4 \pm 0.6$ & & & 1 & tape & Beheaded channel; ?2 events \\
\hline 14 & 2524334 & 5902401 & $\mathrm{M}$ & 063 & channel & $41 \pm 2.5$ & $1 \pm 0.2$ & $\mathrm{nw}$ & 1 & tape & Deflected channel \\
\hline 15 & 2524379 & 5902422 & $\mathrm{M}$ & 068 & channel & $59 \pm 2$ & $1 \pm 0.2$ & nw & 1 & tape & Deflected channel \\
\hline 16 & 2524694 & 5902483 & $\mathrm{M}$ & 062 & terrace & $81.7 \pm 9.8$ & $2.5 \pm 1.2$ & $\mathrm{nw}$ & 1 & photo & Alluvial terrace riser, west bank, Acheron River \\
\hline 17 & 2524903 & 5899479 & $\mathrm{E}$ & 020 & channel & $4.1 \pm 0.5$ & & & 1 & gps & Ephemeral channel; ?single event \\
\hline
\end{tabular}




\begin{tabular}{|c|c|c|c|c|c|c|c|c|c|c|c|}
\hline Site & Easting & Northing & 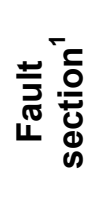 & $\begin{array}{l}\text { Fault } \\
\text { strike }\end{array}$ & $\begin{array}{l}\text { Offset } \\
\text { feature }\end{array}$ & 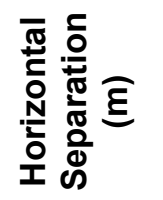 & 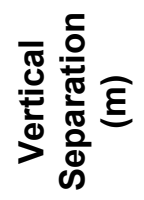 & 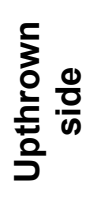 & 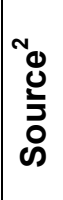 & 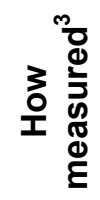 & Notes \\
\hline 18 & 2524903 & 5899479 & $E$ & 020 & channel & $5.5 \pm 0.8$ & & & 1 & gps & Ephemeral channel; ?single event \\
\hline 19 & 2525255 & 5902782 & $\mathrm{M}$ & 062 & terrace & $19.8 \pm 2.1$ & $1 \pm 0.5$ & se & 1 & tape & Alluvial terrace riser, east bank, Acheron River \\
\hline 20 & 2525371 & 5899844 & $\mathrm{E}$ & 063 & terrace & $33.4 \pm 1.5$ & $0.9 \pm 0.2$ & se & 1 & gps & Alluvial terrace riser \\
\hline 21 & 2525374 & 5902878 & $\mathrm{M}$ & 048 & fan & & $5.5 \pm 1.5$ & se & 1 & tape & Tread of beheaded alluvial fan \\
\hline 22 & 2525576 & 5900021 & $E$ & 050 & channel & $6.3 \pm 2.3$ & & ?nw & 1 & gps & Ephemeral channel; ?single event \\
\hline 23 & 2525874 & 5903368 & $\mathrm{M}$ & 068 & spur & $12.5 \pm 1.5$ & & & 1 & tape & \\
\hline 24 & 2526284 & 5900891 & $\mathrm{E}$ & 084 & channel & $21.7 \pm 1.5$ & & & 1 & tape & Deflected channel \\
\hline 25 & 2527692 & 5901658 & MCB & 086 & channel & $12.7 \pm 2.5$ & $0.8 \pm 0.7$ & se & 1 & tape & Ephemeral channel, thalweg on north side of fault partially obscured \\
\hline 26 & 2527763 & 5904321 & $\mathrm{M}$ & 074 & spur & $12 \pm 1$ & & & 1 & tape & Spur displaced across series of ridge rents \\
\hline 27 & 2528179 & 5904578 & $\mathrm{M}$ & 052 & spur & $35.8 \pm 2.2$ & & & 1 & tape & \\
\hline 28 & 2528184 & 5901537 & $E$ & 068 & terrace & $99.5 \pm 19.9$ & & $\mathrm{nw}$ & 1 & photo & Alluvial terrace riser; \\
\hline 29 & 2528400 & 5901723 & $\mathrm{E}$ & 065 & channel & $41.5 \pm 8.3$ & $3.1 \pm 1.4$ & $\mathrm{nw}$ & 1 & photo & Beheaded channel incised into alluvial fan surface \\
\hline 30 & 2528596 & 5904777 & $\mathrm{M}$ & 074 & channel & $51.8 \pm 10.4$ & & & 1 & photo & Deflected channel \\
\hline 31 & 2528767 & 5901953 & MCB & 102 & hillslope & & $3 \pm 1$ & se & 1 & tape & Displaced hillslope \\
\hline 32 & 2528985 & 5901791 & $\mathrm{E}$ & 061 & channel & $15.1 \pm 2$ & & & 1 & tape & Ephemeral channel \\
\hline 33 & 2529280 & 5901835 & $E$ & 066 & spur & $10.4 \pm 1.5$ & & & 1 & tape & \\
\hline 34 & 2529391 & 5901954 & $E$ & 071 & channel & $7.6 \pm 1$ & & & 1 & tape & Deflected channel; minimum displacement due to lateral trimming \\
\hline 35 & 2529507 & 5905247 & $\mathrm{M}$ & 056 & spur & $24 \pm 3.5$ & & & 1 & tape & \\
\hline 36 & 2529769 & 5902253 & $\mathrm{E}$ & 056 & channel & $4.4 \pm 0.3$ & & & 1 & tape & Ephemeral channel; ?single event \\
\hline 37 & 2530030 & 5905578 & $\mathrm{M}$ & 058 & spur & $28 \pm 1.5$ & & & 1 & tape & \\
\hline 38 & 2530645 & 5902891 & $E$ & 050 & channel & $7.4 \pm 1.5$ & & & 1 & tape & Ephemeral channel; minimum displacement due to lateral trimming \\
\hline 39 & 2530750 & 5903226 & $E$ & 060 & channel & $6.2 \pm 1.7$ & $0.3 \pm 0.1$ & $\mathrm{nw}$ & 1 & gps & Ephemeral channel; ?single event \\
\hline 40 & 2530770 & 5903240 & $\mathrm{E}$ & 054 & channel & $5.1 \pm 2.5$ & $0.5 \pm 0.2$ & $\mathrm{nw}$ & 1 & gps & Ephemeral channel; ?single event \\
\hline 41 & 2530795 & 5903263 & $\mathrm{E}$ & 056 & channel & $9.9 \pm 1.7$ & $0.5 \pm 0.3$ & $\mathrm{nw}$ & 1 & gps & Ephemeral channel; ?2 events \\
\hline 42 & 2530803 & 5903267 & $\mathrm{E}$ & 048 & channel & $4.6 \pm 1.3$ & $0.3 \pm 0.2$ & nw & 1 & gps & Ephemeral channel; ?single event \\
\hline 43 & 2530899 & 5903380 & $\mathrm{E}$ & 064 & channel & $9.7 \pm 0.7$ & & & 1 & gps & Beheaded channel, displacement measured w.r.t. fixed headwater; ?2 events \\
\hline 44 & 2530906 & 5903384 & $\mathrm{E}$ & 064 & channel & $5.1 \pm 0.8$ & & & 1 & gps & Beheaded channel, displacement measured w.r.t. fixed headwater; ?single event \\
\hline 45 & 2531110 & 5903455 & $E$ & 045 & channel & $7.8 \pm 1.7$ & & & 1 & gps & Deflected channel \\
\hline 46 & 2531181 & 5906069 & $\mathrm{M}$ & 066 & spur & $29 \pm 1.5$ & & & 1 & tape & \\
\hline 47 & 2531398 & 5903672 & $\mathrm{E}$ & 070 & spur & $6.5 \pm 2.1$ & & & 1 & gps & ?Single event \\
\hline 48 & 2531476 & 5906164 & $\mathrm{M}$ & 074 & spur & $21 \pm 2$ & & & 1 & tape & \\
\hline 49 & 2532344 & 5906465 & $\mathrm{M}$ & 070 & spur & $30.5 \pm 2$ & $1.8 \pm 0.2$ & $\mathrm{nw}$ & 1 & tape & \\
\hline 50 & 2532644 & 5904692 & $E$ & 044 & channel & $31.4 \pm 6.3$ & & & 1 & photo & Deflected channel \\
\hline 51 & 2532830 & 5904857 & $E$ & 032 & channel & $39.1 \pm 7.8$ & & & 1 & photo & Deflected channel \\
\hline 52 & 2532885 & 5904924 & $E$ & 055 & spur & $40 \pm 3$ & & & 1 & tape & \\
\hline 53 & 2532985 & 5905009 & $E$ & 042 & channel & $22.3 \pm 4.5$ & & & 1 & photo & Deflected channel \\
\hline
\end{tabular}




\begin{tabular}{|c|c|c|c|c|c|c|c|c|c|c|c|}
\hline Site & Easting & Northing & 世 & $\begin{array}{l}\text { Fault } \\
\text { strike }\end{array}$ & $\begin{array}{c}\text { Offset } \\
\text { feature }\end{array}$ & 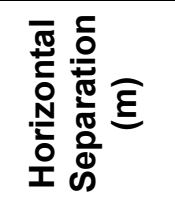 & 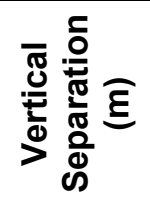 & 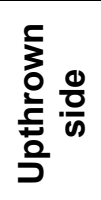 & 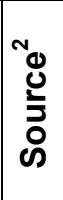 & 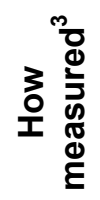 & Notes \\
\hline 54 & 2533291 & 5905311 & $\mathrm{E}$ & 064 & spur & $41 \pm 3.5$ & & & 1 & tape & \\
\hline 55 & 2533315 & 5906768 & $\mathrm{M}$ & 082 & spur & $12 \pm 1$ & & & 1 & tape & \\
\hline 56 & 2533535 & 5906813 & $\mathrm{M}$ & 082 & spur & $20 \pm 1$ & & & 1 & tape & \\
\hline 57 & 2533550 & 5905575 & $\mathrm{E}$ & 070 & fan & $20 \pm 7$ & $8 \pm 2$ & nw & 1 & tape & Crest of alluvial fan \\
\hline 58 & 2534454 & 5906155 & $\mathrm{E}$ & 066 & spur & $25 \pm 3$ & & & 1 & tape & Minimum offset due to lateral trimming \\
\hline 59 & 2534524 & 5906236 & $\mathrm{E}$ & 035 & channel & $80.7 \pm 16.1$ & & & 1 & photo & Deflected channel + adjacent bedrock spur \\
\hline 60 & 2534619 & 5906357 & $E$ & 050 & spur & $21 \pm 2$ & & & 1 & tape & \\
\hline 61 & 2535015 & 5906539 & $\mathrm{E}$ & 063 & channel & $76.5 \pm 15.3$ & & & 1 & photo & Deflected channel + adjacent bedrock spur \\
\hline 62 & 2536815 & 5908280 & $\mathrm{M}$ & 066 & spur & $30 \pm 1.5$ & & & 1 & tape & \\
\hline 63 & 2537581 & 5908778 & $\mathrm{M}$ & 043 & channel & $155.6 \pm 8$ & & & 1 & tape & Total deflection of bedrock channel \\
\hline 64 & 2537735 & 5908870 & $\mathrm{M}$ & 045 & channel & $41.6 \pm 2.5$ & & & 1 & tape & Abandoned/ephemeral channel \\
\hline 65 & 2537749 & 5908884 & $\mathrm{M}$ & 045 & channel & $22.6 \pm 1.5$ & & & 1 & tape & Abandoned/ephemeral channel \\
\hline 66 & 2537756 & 5908890 & $\mathrm{M}$ & 045 & channel & $13 \pm 1.5$ & & & 1 & tape & Abandoned/ephemeral channel \\
\hline 67 & 2538169 & 5909127 & $\mathrm{M}$ & 059 & spur & $3.7 \pm 1$ & $0.5 \pm 0.2$ & se & 1 & tape & ?Single event \\
\hline 68 & 2538175 & 5908636 & $\mathrm{E}$ & 041 & channel & $4.2 \pm 2$ & $0.3 \pm 0.2$ & se & 1 & photo & Ephemeral channel; ?single event \\
\hline 69 & 2538364 & 5908892 & $E$ & 054 & channel & $179 \pm 35.8$ & $5.2 \pm 1.5$ & se & 1 & tape & Deflected channel + alluvial fan surface \\
\hline 70 & 2539735 & 5910064 & $\bar{E}$ & 062 & terrace & $17.6 \pm 2.4$ & $2.2 \pm 1.3$ & nw & 1 & tape & Terrace riser, Kennet River; minimum offset due to trimming of leading edge \\
\hline 71 & 2539878 & 5910453 & $\mathrm{E}$ & 062 & terrace & $17.6 \pm 2.4$ & $2.2 \pm 1.3$ & $\mathrm{nw}$ & 1 & tape & Alluvial terrace riser bounding modern floodplain, Kennet River \\
\hline 72 & 2540675 & 5910634 & $E$ & 058 & spur & $51.5 \pm 5$ & & & 1 & tape & \\
\hline 73 & 2540675 & 5910634 & $\mathrm{E}$ & 058 & spur & $69.6 \pm 5.5$ & & & 1 & tape & \\
\hline 74 & 2541572 & 5911165 & $\mathrm{E}$ & 060 & terrace & $60.9 \pm 6.8$ & $1.5 \pm 0.5$ & se & 1 & tape & Alluvial terrace edge: minimum offset due to lateral trimming \\
\hline 75 & 2541940 & 5911403 & $\mathrm{E}$ & 078 & spur & $84 \pm 16.8$ & & & 1 & photo & \\
\hline 76 & 2542738 & 5912315 & $\mathrm{E}$ & 058 & channel & $18.5 \pm 2.5$ & & & 1 & tape & Deflected channel \\
\hline 77 & 2542823 & 5912356 & $E$ & 058 & channel & $5.3 \pm 1.8$ & & & 1 & tape & Ephemeral channel; ?single event \\
\hline 78 & 2542996 & 5912440 & $\mathrm{E}$ & 058 & spur & $72.5 \pm 4$ & $2.8 \pm 0.2$ & se & 1 & tape & \\
\hline 79 & 2543691 & 5913244 & $\mathrm{E}$ & 038 & hillslope & $109 \pm 21.8$ & & & 1 & photo & Hillslope/colluvial fan edge \\
\hline 80 & 2543864 & 5913382 & $\mathrm{E}$ & 064 & terrace & & $2.5 \pm 0.5$ & se & 1 & tape & Alluvial terrace tread \\
\hline 81 & 2544641 & 5913917 & $\mathrm{E}$ & 046 & channel & $64 \pm 12.8$ & & & 1 & photo & Deflected channel \\
\hline 82 & 2548542 & 5916654 & $\mathrm{E}$ & 072 & channel & $44.6 \pm 12.8$ & $1.8 \pm 0.5$ & se & 1 & gps & Deflected channel \\
\hline 83 & 2548601 & 5916689 & $\mathrm{E}$ & 074 & spur & $84.9 \pm 14.1$ & $2 \pm 0.6$ & se & 1 & gps & Total displacement across ridge rents \\
\hline 84 & 2548828 & 5916784 & $E$ & 076 & spur & $79 \pm 4$ & $2.5 \pm 0.5$ & se & 1 & gps & \\
\hline 85 & 2549126 & 5916977 & $\mathrm{E}$ & 038 & channel & $76.1 \pm 15.2$ & & & 1 & photo & Deflected channel + adjacent bedrock spur \\
\hline 86 & 2551515 & 5918931 & $E$ & 068 & spur & $30 \pm 1.5$ & & & 1 & tape & \\
\hline 87 & 2551515 & 5918931 & $\bar{E}$ & 058 & channel & $32 \pm 3$ & $0.8 \pm 0.2$ & se & 1 & tape & Deflected channel \\
\hline 88 & 2554536 & 5921063 & $\mathrm{E}$ & 074 & spur & $49 \pm 3$ & $1.5 \pm 0.5$ & nw & 1 & tape & \\
\hline 89 & 2555039 & 5921497 & $\mathrm{E}$ & 064 & hillslope & $21 \pm 9$ & & se & 1 & tape & \\
\hline
\end{tabular}




\begin{tabular}{|c|c|c|c|c|c|c|c|c|c|c|c|}
\hline Site & Easting & Northing & 壻 & $\begin{array}{l}\text { Fault } \\
\text { strike }\end{array}$ & $\begin{array}{c}\text { Offset } \\
\text { feature }\end{array}$ & 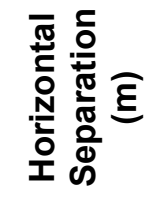 & 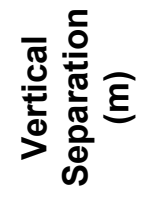 & 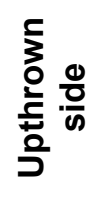 & 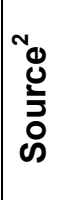 & 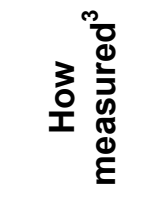 & Notes \\
\hline 90 & 2555041 & 5921499 & $E$ & 068 & channel & $23.7 \pm 6.5$ & $2.5 \pm 0.5$ & se & 1 & tape & Deflected channel + alluvial fan tread \\
\hline 91 & 2555048 & 5921502 & $E$ & 064 & hillslope & $21 \pm 9$ & & se & 1 & tape & \\
\hline 92 & 2555535 & 5921811 & $E$ & 070 & fan & $117.5 \pm 15$ & & & 1 & tape/photo & Alluvial fan edge; minimum offset due to lateral trimming \\
\hline 93 & 2555955 & 5922053 & $E$ & 068 & spur & $58 \pm 2.5$ & & & 1 & tape & \\
\hline 94 & 2556060 & 5922095 & $\mathrm{E}$ & 075 & fan & $51 \pm 3$ & $1 \pm 0.2$ & se & 1 & tape & Alluvial fan edge \\
\hline 95 & 2557140 & 5922711 & $E$ & 058 & spur & $105 \pm 6$ & $6 \pm 1$ & se & 1 & tape & \\
\hline 96 & 2557140 & 5922711 & $E$ & 058 & spur & $40 \pm 10$ & & & 1 & tape & \\
\hline 97 & 2557592 & 5923135 & $\mathrm{E}$ & 055 & fan & $55.5 \pm 3$ & $1.5 \pm 0.2$ & se & 1 & tape & Crest of colluvial fan \\
\hline 98 & 2558300 & 5923800 & $E$ & 053 & terrace & $5.6 \pm 2.1$ & $3.5 \pm 0.2$ & se & 2 & edm & Alluvial terrace riser; ?single event \\
\hline 99 & 2558300 & 5923800 & $E$ & 053 & terrace & $14.5 \pm 2$ & $1.5 \pm 0.3$ & se & 2 & edm & Alluvial terrace riser \\
\hline 100 & 2558300 & 5923800 & $E$ & 053 & terrace & $99 \pm 34$ & $1.3 \pm 0.4$ & se & 2 & edm & Alluvial terrace riser \\
\hline
\end{tabular}

${ }^{1} \mathrm{M}=$ Molesworth section; $\mathrm{E}=$ eastern section; $\mathrm{MCB}=\mathrm{Mt}$ Chisholm block

${ }^{2} 1$ = this study; 2 = Little et al. (1998)

${ }^{3}$ tape $=$ ground parallel measurement of displacement with a tape measure; gps = surveyed using a Real Time Kinematic $($ RTK) GPS system; photo = measured from a scaled and registered aerial photograph; edm = surveyed with a total-station electronic distance meter (EDM) theodolite 


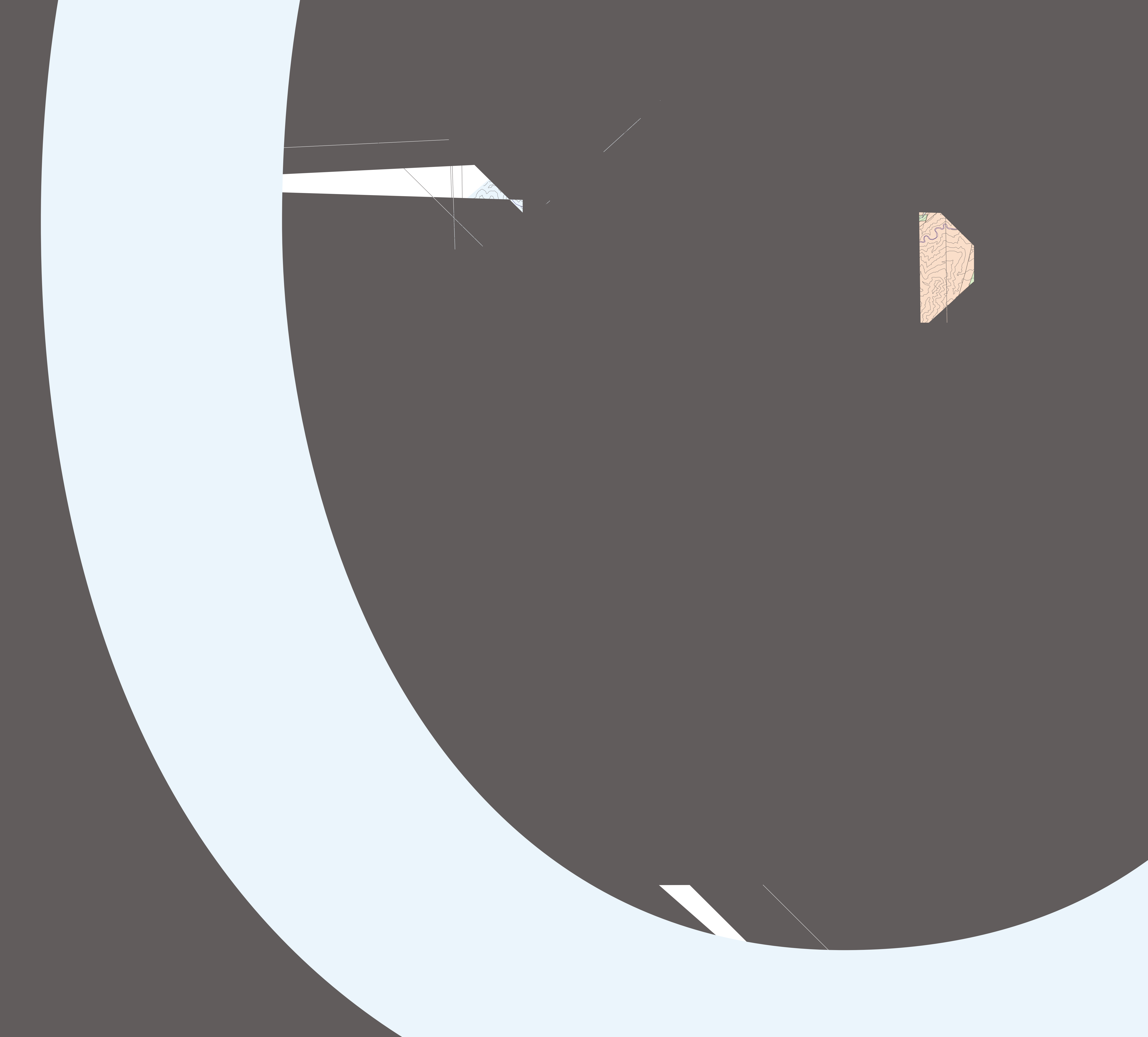




\section{APPENDIX B. LITHOLOGICAL DESCRIPTIONS OF STRATIGRAPHIC UNITS IDENTIFIED IN THE UPCOT AND SAXTON TRENCHES}

Table B.1. Units identified in the Saxton- 2 trench.

\begin{tabular}{|c|c|c|}
\hline $\begin{array}{l}\text { Unit } \\
\text { name }\end{array}$ & Lithology & $\begin{array}{l}\text { Age } \\
\text { (cal. yrs } \\
\text { BP) }\end{array}$ \\
\hline A & Dark brown fibrous peat and carbonaceous silt, abundant modern roots & Modern \\
\hline N1 & $\begin{array}{l}\text { Medium-dark brown fibrous peat, intercalated light-brown fibrous peat, silty } \\
\text { peat and carbonaceous silt, modern rootlets, correlated with C5 }\end{array}$ & \\
\hline $\mathrm{N} 2 \mathrm{a}$ & $\begin{array}{l}\text { Medium brown laminated silty peat, wavy/lenticular bedding } 1-2 \mathrm{~cm} \text { thick, } \\
\text { modern rootlets, basal contact defined by decrease in carbonaceous material, } \\
\text { correlated with C6 } \\
\text { Medium-light brown laminated silty peat, wavy/lenticular bedding } 1-2 \mathrm{~cm} \text { thick, } \\
\text { modern rootlets }\end{array}$ & \\
\hline N3 & $\begin{array}{l}\text { Light brown-grey massive silty clay, minor discontinuous carbonaceous } \\
\text { laminae } 2-4 \mathrm{~mm} \text { thick, non-contemporaneous rootlets, unconformable lower } \\
\text { contact, correlated with } \mathrm{C} 9 / \mathrm{C} 10\end{array}$ & $\begin{array}{l}2460- \\
2750\end{array}$ \\
\hline $\mathrm{N} 4$ & $\begin{array}{l}\text { Blue-grey massive silt, no apparent sedimentary structures, abundant non- } \\
\text { contemporaneous rootlets, gradational lower contact over } 2-3 \mathrm{~cm}\end{array}$ & \\
\hline N5 & $\begin{array}{l}\text { Light brown-grey massive silt, minor light brown carbonaceous silt and silty } \\
\text { peat laminae, sharp basal contact undulatory with }<10 \mathrm{~cm} \text { relief }\end{array}$ & \\
\hline N6 & Blue-grey massive silt, no apparent sedimentary structures, sharp basal contact & \\
\hline N7 & $\begin{array}{l}\text { Dark blue-grey massive silt, fine-grained disseminated charcoal, sharp basal } \\
\text { contact undulatory with }<10 \mathrm{~cm} \text { relief }\end{array}$ & $\begin{array}{c}5750- \\
6000\end{array}$ \\
\hline $\mathrm{N} 8$ & $\begin{array}{l}\text { Blue-grey massive silt, no apparent sedimentary structures, extremely rare well- } \\
\text { rounded to sub-rounded clasts up to } 15 \mathrm{~cm} \text {, rare non-contemporaneous rootlets, } \\
\text { sharp basal contact }\end{array}$ & \\
\hline N9 & $\begin{array}{l}\text { Dark blue-grey massive silt, fine-grained disseminated charcoal, sharp basal } \\
\text { contact }\end{array}$ & $\begin{array}{c}5990- \\
6290\end{array}$ \\
\hline N10 & $\begin{array}{l}\text { Blue-grey massive silt, no apparent sedimentary structures, extremely rare well- } \\
\text { rounded to sub-rounded clasts up to } 15 \mathrm{~cm} \text {, rare non-contemporaneous rootlets, } \\
\text { sharp basal contact }\end{array}$ & \\
\hline $\mathrm{C} 1$ & $\begin{array}{l}\text { Light-medium brown fibrous peat, abundant modern rootlets, gradational top } \\
\text { contact with modern soil, unconformable basal contact }\end{array}$ & $140-440$ \\
\hline $\mathrm{C} 2$ & $\begin{array}{l}\text { Medium-dark brown fibrous peat, minor intercalated light-brown silty peat and } \\
\text { carbonaceous silt, modern rootlets }\end{array}$ & $540-650$ \\
\hline $\mathrm{C} 3$ & $\begin{array}{l}\text { Medium-dark brown fibrous peat, minor intercalated light-brown silty peat and } \\
\text { carbonaceous silt, modern rootlets }\end{array}$ & \\
\hline $\mathrm{C} 4$ & Light brown-grey massive carbonaceous silt, sharp basal contact & $565-670$ \\
\hline $\mathrm{C} 5$ & $\begin{array}{l}\text { Medium brown laminated silty peat, modern rootlets, basal contact defined by } \\
\text { decrease in carbonaceous material }\end{array}$ & $730-920$ \\
\hline C6 & $\begin{array}{l}\text { Medium brown laminated silty peat, minor fibrous peat, modern rootlets, basal } \\
\text { contact defined by decrease in carbonaceous material, correlated with N2 }\end{array}$ & $\begin{array}{l}930- \\
1070 \\
\end{array}$ \\
\hline $\mathrm{C} 7$ & $\begin{array}{l}\text { Medium-dark brown fibrous peat, minor intercalated light-brown silty peat and } \\
\text { carbonaceous silt }\end{array}$ & \\
\hline $\mathrm{C} 8$ & $\begin{array}{l}\text { Light brown-grey massive carbonaceous silt, sharp basal contact defined by } \\
\text { fault zone } 1 \text { strands }\end{array}$ & \\
\hline C9 & $\begin{array}{l}\text { Light brown-grey bedded carbonaceous silt, sharp basal contact, correlated with } \\
\text { N3 }\end{array}$ & \\
\hline
\end{tabular}




\begin{tabular}{|c|c|c|}
\hline $\begin{array}{c}\text { Unit } \\
\text { name }\end{array}$ & Lithology & $\begin{array}{l}\text { Age } \\
\text { (cal. yrs } \\
\text { BP) }\end{array}$ \\
\hline $\mathrm{C} 10$ & $\begin{array}{l}\text { Dark brown carbonaceous silt, fine-grained disseminated charcoal, sharp } \\
\text { unconformable basal contact, correlated with N3 }\end{array}$ & $\begin{array}{c}2350- \\
2660\end{array}$ \\
\hline $\mathrm{C} 11$ & Light brown-grey massive silt, rare rounded clasts up to $5 \mathrm{~cm}$ & $\begin{array}{ll}3070- \\
3360\end{array}$ \\
\hline C12 & $\begin{array}{l}\text { Blue-grey massive silt, no apparent sedimentary structures, gradational lower } \\
\text { contact over } 2-3 \mathrm{~cm} \text {, correlated with } \mathrm{N} 4\end{array}$ & \\
\hline $\mathrm{C} 13$ & $\begin{array}{l}\text { Light brown-grey massive silt, fault-bounded with no apparent sedimentary } \\
\text { structures, rare rounded clasts up to } 8 \mathrm{~cm} \text {, basal contact obscured }\end{array}$ & \\
\hline S1 & $\begin{array}{l}\text { Dark brown fibrous peat and carbonaceous silt, abundant modern roots, } \\
\text { gradational top contact with modern soil }\end{array}$ & \\
\hline S2 & $\begin{array}{l}\text { Dark brown carbonaceous silt, minor fibrous peat, some soil weathering } \\
\text { characteristics (leaching), lenticular wedges of light brown-grey carbonaceous } \\
\text { silt 1-3cm long, sharp basal contact }\end{array}$ & \\
\hline S3 & Light brown-grey massive carbonaceous silt, sharp basal contact & \\
\hline S4 & Blue-grey massive silt, rare rounded clasts up to $5 \mathrm{~cm}$, sharp basal contact & \\
\hline G1 & $\begin{array}{l}\text { Blue-grey unsorted massive gravel, well-rounded to sub-rounded clasts up to } \\
10 \mathrm{~cm} \text {, average clast size }<5 \mathrm{~cm} \text {, medium grey sandy silt matrix, matrix } \\
\text { supported, basal contact sharp }\end{array}$ & $\begin{array}{l}10300- \\
11900\end{array}$ \\
\hline G2 & $\begin{array}{l}\text { Blue-grey poorly sorted gravel, well-rounded clasts up to } 50 \mathrm{~cm} \text {, average clast } \\
\text { size } 15-20 \mathrm{~cm} \text {, sandy silt matrix, matrix supported, basal contact obscured }\end{array}$ & $\begin{array}{l}<13000- \\
16000 ?\end{array}$ \\
\hline G3 & $\begin{array}{l}\text { Blue-grey poorly sorted massive gravel, rounded to angular clasts up to } 10 \mathrm{~cm} \text {, } \\
\text { average clast size }<5 \mathrm{~cm} \text {, pebbly silt matrix, matrix supported, basal contact } \\
\text { sharp (?scoured) }\end{array}$ & \\
\hline G4 & $\begin{array}{l}\text { Blue-grey to red-brown (weathered) unsorted massive gravel, rounded to sub- } \\
\text { rounded clasts up to } 30 \mathrm{~cm} \text {, average clast size } 15-20 \mathrm{~cm} \text {, sandy silt matrix, } \\
\text { matrix supported, basal contact defined by decrease in clast size }\end{array}$ & \\
\hline G5 & $\begin{array}{l}\text { Red-brown to brown-grey poorly sorted gravel, crudely imbricated sub-rounded } \\
\text { clasts up to } 10 \mathrm{~cm} \text {, average clast size }<3 \mathrm{~cm} \text {, coarse silty sand matrix, matrix } \\
\text { supported, basal contact defined by increase in rusty weathering, gradational } \\
\text { lateral contact with } \mathrm{G} 7 \text { defined by coarsening of matrix }\end{array}$ & \\
\hline G6 & $\begin{array}{l}\text { Brown-grey very poorly sorted gravel, rounded to sub-angular clasts up to } \\
25 \mathrm{~cm} \text {, average clast size } 3-4 \mathrm{~cm} \text {, silty sand matrix, matrix supported with clast- } \\
\text { supported zones, basal contact defined by clast size increase in G4, modern soil } \\
\text { formation affecting top } 30-40 \mathrm{~cm}\end{array}$ & \\
\hline G7 & $\begin{array}{l}\text { Brown-grey very poorly sorted massive gravel, rounded to sub-rounded clasts } \\
\text { up to } 15 \mathrm{~cm} \text {, average clast size } 3-5 \mathrm{~cm} \text {, silt matrix, matrix supported, basal } \\
\text { contact sharp }\end{array}$ & \\
\hline G8 & $\begin{array}{l}\text { Blue-grey unsorted silt }+ \text { gravel, sub-rounded clasts up to } 30 \mathrm{~cm} \text {, average clast } \\
\text { size } 5 \mathrm{~cm} \text {, silty clay matrix, matrix supported, abundant sub-vertical shears, large } \\
\text { clasts vertically imbricated, lateral contacts defined by fault zones } 1 \text { and } 2\end{array}$ & \\
\hline G9 & $\begin{array}{l}\text { Brown-grey very poorly sorted massive gravel, rounded to sub-rounded clasts } \\
\text { up to } 10 \mathrm{~cm} \text {, average clast size } 2-3 \mathrm{~cm} \text {, silt matrix, matrix supported, basal } \\
\text { contact sharp }\end{array}$ & \\
\hline G10 & $\begin{array}{l}\text { Brown-grey very poorly sorted massive gravel, rounded to sub-rounded clasts } \\
\text { up to } 10 \mathrm{~cm} \text {, average clast size } 2-3 \mathrm{~cm} \text {, silt matrix, matrix supported, basal } \\
\text { contact sharp }\end{array}$ & \\
\hline G11 & $\begin{array}{l}\text { Blue-grey massive silt and rounded clasts up to } 15 \mathrm{~cm} \text {, average clast size } 3-5 \mathrm{~cm} \text {, } \\
\text { unconformable basal contact }\end{array}$ & \\
\hline Bedrock & $\begin{array}{l}\text { (Torlesse greywacke): Highly sheared blue-grey indurated well-sorted fine- } \\
\text { medium grained sandstone, no visible fossils, bedding obscured by deformation }\end{array}$ & \\
\hline
\end{tabular}


Table B.2. Units identified in the Upcot- 1 trench

\begin{tabular}{|c|c|c|}
\hline $\begin{array}{l}\text { Unit } \\
\text { name }\end{array}$ & Lithology & $\begin{array}{l}\text { Age } \\
\text { (cal. yrs } \\
\text { BP) }\end{array}$ \\
\hline $\mathrm{A} 1$ & Dark brown-grey massive silt + fibrous peat, abundant modern roots & \\
\hline A2 & $\begin{array}{l}\text { Dark brown-grey to red-brown silt and sand, rare angular clasts up to } 10 \mathrm{~cm} \text {, } \\
\text { roots in growth position, gradational basal contact }\end{array}$ & \\
\hline B1 & $\begin{array}{l}\text { Brown-grey massive carbonaceous silt, abundant modern roots, rare charcoal } \\
\text { and lenticular sand layers, sharp basal contact, gradational top contact with } \\
\text { modern soil horizon over } 6-8 \mathrm{~cm}\end{array}$ & \\
\hline B2 & $\begin{array}{l}\text { Blue-grey to brown-grey poor to unsorted massive gravel, angular to sub- } \\
\text { angular clasts up to } 15 \mathrm{~cm} \text {, average clast size } 2-5 \mathrm{~cm} \text {, sandy silt matrix, matrix } \\
\text { supported, erosional basal contact, eroded to } \mathrm{SE} \text { of fault zone } 1 \text { by lenticular } \\
\text { channel-fill gravel lobe }\end{array}$ & \\
\hline N1 & $\begin{array}{l}\text { Brown-grey massive carbonaceous silt, rare charcoal and rootlets, lenticular } \\
\text { sand and fine gravel layers, sharp basal contact ( } 5 \mathrm{~mm} \text { thick sand layer), } \\
\text { interfingering contact with laterally adjacent gravel to NW, abuts against } \\
\text { deformational bulge to SE }\end{array}$ & $\begin{array}{l}960- \\
1260\end{array}$ \\
\hline N2 & $\begin{array}{l}\text { Light to dark brown fibrous peat, bedded on } \mathrm{mm} \text { scale, rare detrital wood, } \\
\text { charcoal and small sub-rounded pebbles }<2 \mathrm{~mm} \text {, gradational basal contact }\end{array}$ & \\
\hline N3 & $\begin{array}{l}\text { Light to dark brown fibrous peat, bedded on } \mathrm{mm} \text { scale, rare detrital wood, } \\
\text { charcoal and small sub-rounded pebbles }<2 \mathrm{~mm} \text {, lateral change (interfingering) } \\
\text { into massive silt, gradational basal contact }\end{array}$ & \\
\hline N4 & $\begin{array}{l}\text { Blue-grey to brown-grey massive silt, interbedded carbonaceous silt/fine peat } \\
\text { layers, small lenticular fine sand layers } 2-5 \mathrm{~cm} \text { long, gradational basal contact } \\
\text { with underlying peat, interfingering contact with superjacent peat }\end{array}$ & \\
\hline N5 & $\begin{array}{l}\text { Light brown fine peat } 5-8 \mathrm{~cm} \text { thick, bedded on } \mathrm{mm} \text { scale, roots preserved in } \\
\text { growth position and deposited detritally, rare charcoal, rare carbonaceous silt } \\
\text { laminae, gradational basal contact into underlying massive silt }\end{array}$ & $\begin{array}{l}1600- \\
1890\end{array}$ \\
\hline N6 & $\begin{array}{l}\text { Blue-grey massive silt, interbedded carbonaceous silt/fine peat layers, lenticular } \\
\text { fine sand layers, sharp basal contact }\end{array}$ & $\begin{array}{c}3380- \\
3640\end{array}$ \\
\hline N7 & $\begin{array}{l}\text { Blue-grey poor to unsorted massive gravel, angular clasts up to } 20 \mathrm{~cm} \text {, average } \\
\text { clast size } 3-5 \mathrm{~cm} \text {, silty clay matrix, matrix supported, sharp (unconformable?) } \\
\text { basal contact. Fining trend to NW (away from fault zone 1) to blue-grey poorly } \\
\text { sorted massive sandy gravel }\end{array}$ & \\
\hline N8-10 & $\begin{array}{l}\text { Intercalated blue-grey, poorly sorted fine sand-sandy gravel layers, clast } \\
\text { supported with clay matrix, undulatory basal contacts }\end{array}$ & \\
\hline N11 & $\begin{array}{l}\text { Dark brown fine peat, } \mathrm{mm}-\mathrm{cm} \text { bedding/banding, fine plant material, rare detrital } \\
\text { wood fragments, light brown-grey organic silt laminae, sharp basal contact }\end{array}$ & $\begin{array}{c}5050- \\
5600\end{array}$ \\
\hline N12 & $\begin{array}{l}\text { Blue-grey poor to moderately sorted crudely bedded gravel, angular to sub- } \\
\text { angular clasts up to } 5 \mathrm{~cm} \text {, average clast size } 0.5-2 \mathrm{~cm} \text {, clast supported with silt } \\
\text { matrix, erosional basal contact with }<5 \mathrm{~cm} \text { of relief adjacent to fault zone } 1\end{array}$ & \\
\hline N13 & $\begin{array}{l}\text { Dark to light brown banded fine peat, banded on } \mathrm{mm}-\mathrm{cm} \text { scale, fine rootlets } \\
\text { preserved in growth position in basal contact with } \mathrm{N} 14 \text {, lenticular fine sand } \\
\text { layers }<3-5 \mathrm{~cm} \text { present }\end{array}$ & $\begin{array}{c}4960- \\
5310\end{array}$ \\
\hline N14 & $\begin{array}{l}\text { Blue-grey poorly sorted massive gravel, angular to sub-angular clasts up to } \\
30 \mathrm{~cm} \text {, average clast size } 3-5 \mathrm{~cm} \text {, clast supported with muddy sand matrix, } \\
\text { crudely fining up with largest clasts at base }\end{array}$ & \\
\hline N15 & $\begin{array}{l}\text { Dark brown fine peat, gradational lower contact over } 10-20 \mathrm{~cm} \text { of light brown } \\
\text { organic silt/fine peat into organic silt below }\end{array}$ & $\begin{array}{c}5310- \\
5590\end{array}$ \\
\hline S1a-d & $\begin{array}{l}\text { Blue-grey poor to unsorted massive gravel, angular to sub-rounded clasts up to } \\
15 \mathrm{~cm} \text {, average clast size } 1-5 \mathrm{~cm} \text {, silt matrix, matrix supported, sharp basal } \\
\text { contact } \\
\text { Sub-units: blue-grey silt with cobble-rich gravel at base; clayey silt with rare } \\
\text { cobbles above; silt with pebbly sand to SE }\end{array}$ & \\
\hline S2 & $\begin{array}{l}\text { Blue-green moderately-well sorted pebbly sand, angular to sub-angular clasts up } \\
\text { to } 3-5 \mathrm{~cm} \text {, average clast size }<1 \mathrm{~cm} \text {, organic silt-rich areas, silty clay matrix, }\end{array}$ & \\
\hline
\end{tabular}




\begin{tabular}{|c|c|c|}
\hline $\begin{array}{l}\text { Unit } \\
\text { name }\end{array}$ & Lithology & $\begin{array}{l}\text { Age } \\
\text { (cal. yrs } \\
\text { BP) }\end{array}$ \\
\hline & matrix supported, interfingering lateral contact with N6, sharp basal contact & \\
\hline S3 & $\begin{array}{l}\text { Blue-grey poor to unsorted massive gravel, angular clasts up to } 20 \mathrm{~cm} \text {, average } \\
\text { clast size } 3-5 \mathrm{~cm} \text {, silty clay matrix, matrix supported, sharp basal contact, } \\
\text { correlated with N7 }\end{array}$ & \\
\hline S4-6 & $\begin{array}{l}\text { Intercalated blue-grey, poorly sorted fine sand-sandy gravel layers, clast } \\
\text { supported with clay matrix, undulatory basal contacts, correlated with N8-10 }\end{array}$ & \\
\hline S7 & $\begin{array}{l}\text { Dark brown fine peat, } \mathrm{mm} \text {-cm bedding/banding, fine plant material, rare detrital } \\
\text { wood fragments, light brown-grey organic silt laminae, sharp basal contact, } \\
\text { correlated with N11 }\end{array}$ & \\
\hline S8 & $\begin{array}{l}\text { Blue-grey poorly sorted massive gravel, angular to sub-angular clasts up to } \\
5 \mathrm{~cm} \text {, average clast size } 0.5-2 \mathrm{~cm} \text {, clast supported with silt matrix, erosional basal } \\
\text { contact with }<5 \mathrm{~cm} \text { of relief adjacent to fault zone } 1 \text {, correlated with } \mathrm{N} 12\end{array}$ & \\
\hline S9 & $\begin{array}{l}\text { Dark to light brown banded fine peat, banded on } \mathrm{mm}-\mathrm{cm} \text { scale, sharp basal } \\
\text { contact, correlated with N13 }\end{array}$ & \\
\hline G1 & $\begin{array}{l}\text { Pale brown friable unsorted massive gravel, angular clasts up to } 10 \mathrm{~cm} \text {, average } \\
\text { clast size } 5 \mathrm{~cm} \text {, silt matrix, matrix supported, sharp basal contact }\end{array}$ & \\
\hline G2 & $\begin{array}{l}\text { Yellow-brown friable poor to unsorted massive gravel, angular clasts up to } \\
12 \mathrm{~cm} \text {, average clast size } 5-8 \mathrm{~cm} \text {, silt matrix, matrix supported, basal contact } \\
\text { defined by stoneline/differential weathering }\end{array}$ & \\
\hline G3 & $\begin{array}{l}\text { Pale brown poorly sorted gravel, angular clasts up to } 20 \mathrm{~cm} \text { (rare), average clast } \\
\text { size } 1-2 \mathrm{~cm} \text {, sandy silt matrix, matrix supported, basal contact defined by } 3-5 \mathrm{~cm} \\
\text { thick zone of darker brown weathering (?paleosol) }\end{array}$ & \\
\hline G4 & $\begin{array}{l}\text { Blue-grey to pale brown poorly sorted massive gravel, angular clasts up to } 7 \mathrm{~cm} \text {, } \\
\text { average clast size } 1-2 \mathrm{~cm} \text {, silt matrix, matrix supported, basal contact on } \mathrm{SW} \\
\text { wall defined by increase in average clast size, basal contact on NE wall defined } \\
\text { by stone line }\end{array}$ & \\
\hline G5 & $\begin{array}{l}\text { Blue-grey to yellow-brown very poorly sorted crudely bedded gravel, angular } \\
\text { clasts up to } 6 \mathrm{~cm} \text {, average clast size } 1-3 \mathrm{~cm} \text {, sandy silt matrix, matrix supported, } \\
\text { basal contact defined by increase in average clast size, zone of crushing, yellow- } \\
\text { red oxidation (?hematite) and high groundwater flow above fault zone } 2\end{array}$ & $\begin{array}{c}3830- \\
4090\end{array}$ \\
\hline G6 & $\begin{array}{l}\text { Blue-grey to green-grey massive gravely silt, rare angular clasts up to } 10 \mathrm{~cm} \text {, } \\
\text { average clast size } 2-3 \mathrm{~cm} \text {, clayey silt matrix, matrix supported, basal contact } \\
\text { defined by increase in proportion of silt matrix }\end{array}$ & \\
\hline G7 & $\begin{array}{l}\text { Blue-grey poor sorted massive gravel, angular to sub-angular clasts up to } 5 \mathrm{~cm} \text {, } \\
\text { average clast size } 1-2 \mathrm{~cm} \text {, silt matrix, matrix supported, basal contact defined by } \\
\text { large increase in proportion of silt }\end{array}$ & \\
\hline G8 & $\begin{array}{l}\text { Green-grey very poorly sorted gravely silt, angular clasts up to } 10 \mathrm{~cm} \text {, average } \\
\text { clast size } 2-3 \mathrm{~cm} \text {, silt matrix, matrix supported, basal contact defined by increase } \\
\text { in clast concentration }\end{array}$ & \\
\hline G9 & $\begin{array}{l}\text { Yellow-brown friable poorly sorted massive gravel, angular clasts up to } 7 \mathrm{~cm} \text {, } \\
\text { average clast size } 1-2 \mathrm{~cm} \text {, silt matrix, matrix supported, basal contact defined by } \\
\text { decrease in average clast size }\end{array}$ & \\
\hline G10 & $\begin{array}{l}\text { Yellow-brown friable poorly sorted massive gravel, angular clasts up to } 7 \mathrm{~cm} \text {, } \\
\text { average clast size } 1-2 \mathrm{~cm} \text {, silt matrix, matrix supported, sharp basal contact }\end{array}$ & \\
\hline G11 & $\begin{array}{l}\text { Blue-grey to grey-brown poorly sorted massive gravel, angular to sub-angular } \\
\text { clasts up to } 10 \mathrm{~cm} \text {, average clast size } 1-2 \mathrm{~cm} \text {, silt matrix, matrix supported, basal } \\
\text { contact at bench level }\end{array}$ & \\
\hline G12 & $\begin{array}{l}\text { Blue-grey to green-grey massive gravely silt, angular clasts up to } 5 \mathrm{~cm} \text {, average } \\
\text { clast size } 1-2 \mathrm{~cm} \text {, clayey silt matrix, matrix supported, basal contact defined by } \\
\text { decrease in gravel-sized clast concentration }\end{array}$ & \\
\hline G13 & $\begin{array}{l}\text { Blue-grey massive silty gravel, angular to sub-angular clasts up to } 5 \mathrm{~cm} \text { (rare), } \\
\text { average clast size }<1 \mathrm{~cm} \text {, silt matrix, matrix supported, basal contact defined by } \\
\text { increase in average clast size }\end{array}$ & \\
\hline G14 & $\begin{array}{l}\text { Brown-grey poorly sorted massive gravel, angular clasts up to } 12 \mathrm{~cm} \text {, sandy silt } \\
\text { matrix, matrix supported, basal contact defined by crude imbrication of clasts in } \\
\text { fault zone } 2 \text { strand }\end{array}$ & \\
\hline
\end{tabular}




\begin{tabular}{|c|c|c|}
\hline $\begin{array}{c}\text { Unit } \\
\text { name }\end{array}$ & Lithology & $\begin{array}{l}\text { Age } \\
\text { (cal. yrs } \\
\text { BP) }\end{array}$ \\
\hline G15 & $\begin{array}{l}\text { Brown-grey indurated unsorted gravel, angular clasts up to } 20 \mathrm{~cm} \text {, sandy silt } \\
\text { matrix, matrix supported, lateral contacts defined by crude imbrication of clasts } \\
\text { of fault zone } 2 \text { strands }\end{array}$ & \\
\hline G16 & $\begin{array}{l}\text { Blue grey to green-grey poorly sorted massive silty gravel, angular to sub- } \\
\text { angular clasts up to } 15 \mathrm{~cm} \text {, average clast size } 1-3 \mathrm{~cm} \text {, silt matrix, matrix } \\
\text { supported, basal contact defined by concentration of largest clasts }\end{array}$ & \\
\hline G17 & $\begin{array}{l}\text { Green-grey massive silt, rare angular clasts } 2-3 \mathrm{~cm} \text {, basal contact defined by } \\
\text { fault zone } 1 \text { strand }\end{array}$ & \\
\hline G18 & $\begin{array}{l}\text { Light brown-grey poorly sorted massive silty gravel, angular to sub-angular } \\
\text { clasts up to } 5 \mathrm{~cm} \text {, average clast size } 2 \mathrm{~cm} \text {, silt matrix, matrix supported, basal } \\
\text { contact defined by increase in silt }\end{array}$ & \\
\hline G19 & $\begin{array}{l}\text { Brown-grey friable very poorly sorted gravel, angular clasts up to } 5 \mathrm{~cm} \text {, silt } \\
\text { matrix, matrix supported, basal contact not seen }\end{array}$ & \\
\hline G20 & $\begin{array}{l}\text { Brown-grey poorly sorted sandy gravel, angular to sub-angular clasts up to } \\
10 \mathrm{~cm} \text {, average clast size } 1-2 \mathrm{~cm} \text {, silty sand matrix, matrix supported, gradational } \\
\text { basal contact defined by increase in clast size and colour change }\end{array}$ & \\
\hline G21 & $\begin{array}{l}\text { Pale brown to brown-grey poorly sorted massive gravel, angular to sub-angular } \\
\text { clasts up to } 20 \mathrm{~cm} \text {, average clast size } 3 \mathrm{~cm} \text {, silty sand matrix, matrix supported, } \\
\text { gradational basal contact defined by crude imbrication of larger clasts }\end{array}$ & \\
\hline G22 & $\begin{array}{l}\text { Pale brown to brown-grey poorly sorted massive gravel, angular to sub-angular } \\
\text { clasts up to } 20 \mathrm{~cm} \text {, average clast size } 3 \mathrm{~cm} \text {, silty sand matrix, matrix supported, } \\
\text { basal contact defined by main fault zone } 2 \text { strand }\end{array}$ & \\
\hline G23 & $\begin{array}{l}\text { Blue-grey poorly sorted massive gravely sand, very rare angular clasts up to } \\
5 \mathrm{~cm} \text {, average clast size }<0.5 \mathrm{~cm} \text {, fine sand-silt matrix, matrix supported, basal } \\
\text { contact defined by } 1-2 \mathrm{~cm} \text { thick clay layer }\end{array}$ & \\
\hline G24 & $\begin{array}{l}\text { Blue-grey poorly sorted crudely bedded silty gravel, angular to sub-angular } \\
\text { clasts up to } 1-2 \mathrm{~cm} \text {, sandy silt matrix, matrix supported, basal contact defined by } \\
\text { inferred fault zone } 2 \text { strand }\end{array}$ & \\
\hline G25 & $\begin{array}{l}\text { Blue-grey to green-grey massive gravely silt, rare angular clasts } 3-10 \mathrm{~cm} \text {, clayey } \\
\text { silt matrix, matrix supported, basal contact defined by fault zone } 1\end{array}$ & \\
\hline G26 & $\begin{array}{l}\text { Blue-grey to green-grey massive gravely silt, rare angular clasts } 3-10 \mathrm{~cm} \text {, clayey } \\
\text { silt matrix, matrix supported, basal contact defined by fault zone } 1\end{array}$ & \\
\hline Bedrock & $\begin{array}{l}\text { Brown-grey unsorted matrix-poor fractured greywacke/indurated colluvium, } \\
\text { angular clasts up to } 50 \mathrm{~cm}\end{array}$ & \\
\hline
\end{tabular}


Table B.3. Units identified in the Upcot- 2 trench

\begin{tabular}{|c|c|c|}
\hline $\begin{array}{c}\text { Unit } \\
\text { name }\end{array}$ & Lithology & $\begin{array}{l}\text { Age } \\
\text { (cal. yrs } \\
\text { BP) }\end{array}$ \\
\hline A1 & Dark brown-grey massive silt + fibrous peat, abundant modern roots & \\
\hline A2 & $\begin{array}{l}\text { Blue-grey to brown-grey poor to unsorted massive gravel, angular to sub- } \\
\text { angular clasts up to } 7 \mathrm{~cm} \text {, average clast size } 2-3 \mathrm{~cm} \text {, silty sand matrix, matrix } \\
\text { supported, erosional basal contact }\end{array}$ & \\
\hline A3 & $\begin{array}{l}\text { Brown-grey massive carbonaceous silt and dark brown peat, abundant modern } \\
\text { roots, sharp basal contact, gradational top contact with modern soil horizon over } \\
5-10 \mathrm{~cm}\end{array}$ & $10-280$ \\
\hline B1 & $\begin{array}{l}\text { Blue-grey to poorly sorted massive gravel, angular to sub-angular clasts up to } \\
6 \mathrm{~cm} \text {, average clast size } 0.5-1 \mathrm{~cm} \text {, clast supported with silt matrix, erosional } \\
\text { (wavy) basal contact }\end{array}$ & \\
\hline B2 & $20 \mathrm{~cm}$ long lens of dark brown silty peat, truncated beneath $\mathrm{A} 2$ & $0-290$ \\
\hline B3 & $\begin{array}{l}\text { Blue-grey poorly sorted very fine gravel, angular clasts up to } 1 \mathrm{~cm} \text {, average clast } \\
\text { size } 5-7 \mathrm{~mm} \text {, silt matrix, matrix supported, erosional basal contact }\end{array}$ & \\
\hline N1 & $\begin{array}{l}\text { Dark brown-grey massive carbonaceous silt, abundant rootlets, gradational } \\
\text { basal contact over } 3-5 \mathrm{~cm}\end{array}$ & \\
\hline $\mathrm{N} 2$ & $\begin{array}{l}\text { Brown-grey massive carbonaceous silt, occasional rootlets and rare charcoal, } \\
\text { gradational basal contact over } 2-3 \mathrm{~cm}\end{array}$ & \\
\hline N3 & $\begin{array}{l}\text { Brown-grey massive carbonaceous silt, occasional lenticular sand layers up to } \\
0.5 \mathrm{~cm} \text { thick, sharp basal contact }\end{array}$ & \\
\hline N4 & $\begin{array}{l}\text { Brown-grey poorly sorted silty gravel, angular to sub-angular clasts up to } 7 \mathrm{~cm} \text {, } \\
\text { average clast size } 3 \mathrm{~cm} \text {, silty sand matrix, matrix supported, basal contact } \\
\text { defined by zone of soil weathering (?modern B horizon) }\end{array}$ & \\
\hline N5 & $\begin{array}{l}\text { Brown-grey poorly sorted silty gravel, angular to sub-angular clasts up to } 7 \mathrm{~cm} \text {, } \\
\text { average clast size } 3 \mathrm{~cm} \text {, silty sand matrix, matrix supported, basal contact } \\
\text { defined by stoneline, grades laterally into N6 }\end{array}$ & \\
\hline N6 & $\begin{array}{l}\text { Brown-grey poorly sorted pebbly gritty sandy mud, angular to sub-angular } \\
\text { clasts up to } 5 \mathrm{~cm} \text {, average clast size } 2 \mathrm{~cm} \text {, silt matrix, matrix supported, basal } \\
\text { contact defined by increase in sand matrix }\end{array}$ & \\
\hline $\mathrm{N} 7 \mathrm{a}$ & $\begin{array}{l}\text { Blue-grey to brown-grey poor to unsorted massive gravel, angular to sub- } \\
\text { angular clasts up to } 7 \mathrm{~cm} \text {, average clast size } 2-3 \mathrm{~cm} \text {, silty sand matrix, matrix } \\
\text { supported, erosional basal contact }\end{array}$ & \\
\hline $\mathrm{N} 7 \mathrm{~b}$ & $\begin{array}{l}\text { Dark brown fibrous peat and carbonaceous silt, woody detritus and occasional } \\
<1 \mathrm{~cm} \text { pebbles }\end{array}$ & \\
\hline $\mathrm{N} 8$ & Dark brown carbonaceous silt, woody detritus, $<1 \mathrm{~cm}$ laminated inorganic silt & \\
\hline N9 & $\begin{array}{l}\text { Brown carbonaceous sandy silt, rare wood fragments and angular pebbles } \\
<3 \mathrm{~cm} . \\
{ }^{*} \text { These }{ }^{14} \mathrm{C} \text { samples returned non-sequential ages: sample } 9(970-1180 \text { cal. } \\
\text { years B.P.) is } \sim 0.5 \mathrm{~m} \text { below sample } 11 \text { ( } 1350-1550 \text { cal. years B.P.) }\end{array}$ & $\begin{array}{l}970- \\
1180 \\
1350- \\
1550^{*}\end{array}$ \\
\hline N10 & $\begin{array}{l}\text { Green-grey poorly sorted massive gravel, angular clasts up to } 5 \mathrm{~cm} \text {, average } \\
\text { clast size } 1-2 \mathrm{~cm} \text {, sand matrix, matrix supported, basal contact defined by } \\
\text { decrease in matrix and increase in clast size }\end{array}$ & \\
\hline N11 & $\begin{array}{l}\text { Yellow-brown friable poor to unsorted massive gravel, angular clasts up to } 8 \mathrm{~cm} \text {, } \\
\text { average clast size } 3 \mathrm{~cm} \text {, silty sand matrix, matrix supported, basal contact } \\
\text { defined by increase in clast size }\end{array}$ & \\
\hline N12 & $\begin{array}{l}\text { Brown-grey coarse sandy gravel, angular clasts up to } 10 \mathrm{~cm} \text {, average clast size } \\
2-3 \mathrm{~cm} \text {, sand matrix, matrix supported, basal contact defined by increase in clast } \\
\text { size }\end{array}$ & \\
\hline N13 & $\begin{array}{l}\text { Yellow-brown friable poorly sorted massive gravel, angular clasts up to } 30 \mathrm{~cm} \text {, } \\
\text { average clast size } 8-9 \mathrm{~cm} \text {, clast supported with silty sand matrix }\end{array}$ & \\
\hline
\end{tabular}




\begin{tabular}{|c|c|c|}
\hline $\begin{array}{c}\text { Unit } \\
\text { name }\end{array}$ & Lithology & $\begin{array}{l}\text { Age } \\
\text { (cal. yrs } \\
\text { BP) }\end{array}$ \\
\hline S1a & $\begin{array}{l}\text { Dark brown-grey massive carbonaceous silt, abundant rootlets, gradational } \\
\text { basal contact over } 3-5 \mathrm{~cm} \\
\text { Correlated with } \mathrm{N} 1 \\
\text { Fault-bounded wedge of dark brown massive carbonaceous silt, gradational top } \\
\text { contact over } 3-8 \mathrm{~cm}\end{array}$ & $0-310$ \\
\hline S2 & $\begin{array}{l}\text { Brown-grey massive carbonaceous silt, occasional rootlets and rare charcoal, } \\
\text { gradational basal contact over } 2-3 \mathrm{~cm} \text {, correlated with } \mathrm{N} 2\end{array}$ & $740-920$ \\
\hline S3 & $\begin{array}{l}\text { Brown-grey massive carbonaceous silt, occasional lenticular sand layers up to } \\
0.5 \mathrm{~cm} \text { thick, rootlets, }<1 \mathrm{~cm} \text { pebbles, sharp basal contact }\end{array}$ & \\
\hline S4 & $\begin{array}{l}\text { Brown-grey massive carbonaceous silt, occasional lenticular sand layers up to } \\
0.5 \mathrm{~cm} \text { thick, sharp basal contact, correlated with } \mathrm{N} 3\end{array}$ & $790-940$ \\
\hline S5 & Brown-grey massive carbonaceous silt, occasional wood fragments & $\begin{array}{c}1080- \\
1300\end{array}$ \\
\hline S6-10 & $\begin{array}{l}\text { Finely laminated sequence of blue-grey massive silt (S6, S7), bedded dark } \\
\text { brown fine peat (S8), brown-grey poorly sorted silty gravel (S9) and brown- } \\
\text { grey carbonaceous silt (S10) }\end{array}$ & $\begin{array}{l}3080- \\
3390\end{array}$ \\
\hline S11-14 & $\begin{array}{l}\text { Blue-grey to brown-grey poor to unsorted massive gravel, angular to sub- } \\
\text { angular clasts up to } 7 \mathrm{~cm} \text {, average clast size } 2-3 \mathrm{~cm} \text {, silty sand matrix, matrix } \\
\text { supported, erosional basal contact, minor lenses of dark brown fine peat }(\mathrm{S} 11 \text {, } \\
\text { S13) }\end{array}$ & $\begin{array}{l}2770- \\
2960\end{array}$ \\
\hline S15 & $\begin{array}{l}\text { Brown-grey sandy clay, occasional deformed sand laminae }<2 \mathrm{~cm} \text { thick, } \\
\text { unsorted massive pebbly silt at top, fault-bounded }\end{array}$ & \\
\hline S16 & $\begin{array}{l}\text { Blue-grey unsorted massive gravel, angular clasts up to } 20 \mathrm{~cm} \text {, average clast size } \\
5-9 \mathrm{~cm} \text {, sandy silt matrix, matrix supported, abundant rootlets }\end{array}$ & \\
\hline S17 & $\begin{array}{l}\text { Green-grey very poorly sorted massive gravel, angular clasts up to } 10 \mathrm{~cm} \text {, } \\
\text { average clast size } 1-2 \mathrm{~cm} \text {, sand matrix, matrix supported }\end{array}$ & \\
\hline S18 & Brown-grey massive sandy silt, sub-rounded coarse sand particles $1-2 \mathrm{~mm}$ & \\
\hline S19 & $\begin{array}{l}\text { Dark brown carbonaceous silt, woody detritus, }<1 \mathrm{~cm} \text { laminated inorganic silt, } \\
\text { correlated with lowest } \mathrm{N} 8\end{array}$ & \\
\hline S20 & $\begin{array}{l}\text { Brown carbonaceous sandy silt, rare wood fragments and angular pebbles } \\
<3 \mathrm{~cm} \text {, correlated with N9/N10 }\end{array}$ & \\
\hline G1-6 & $\begin{array}{l}\text { Brown-grey to blue-grey poorly sorted massive gravel, angular clasts up to } \\
15 \mathrm{~cm} \text {, sandy silt matrix, matrix supported }\end{array}$ & \\
\hline Bedrock & $\begin{array}{l}\text { Brown-grey unsorted matrix-poor fractured greywacke/indurated colluvium, } \\
\text { angular clasts up to } 50 \mathrm{~cm}\end{array}$ & \\
\hline
\end{tabular}

